\title{
THE POLITICS OF FERTILITY: THE GLOBAL EMERGENCE OF 'PRO-FAMILY' ORGANISATIONS
}

By

Jennifer Wigley

\author{
A thesis \\ submitted to Victoria University of Wellington \\ in fulfilment of the requirements for the degree of \\ Doctor of Philosophy \\ in Political Science
}

Victoria University of Wellington

2009 


Abstract
This thesis is part of a small but growing literature on the activism of Christian
Right 'pro-family' organisations from the United States (US) in international
development politics. This thesis provides a detailed analysis of the texts of five
globally active 'pro-family' organisations from 1997 until the end of 2008. One of
the major findings is that the 'pro-family' political project, previously defined as the
defence of the family against powerful global elites, is now being articulated against
values associated with industrialisation and modernity. Through this change, long-
held Christian Right tenets such as hostility to feminism, staunch adherence to free
markets, and suspicion of the UN, are being reconsidered or redefined to suit the
needs of the 'pro-family' movement. By mapping the ways that 'pro-family'
discourse is changing, this thesis shows the impacts that globalization and
involvement at the UN is having on this set of conservative Christians, and how
their agenda is changing as a result of their political activism outside of the US.
This thesis provides a current, comprehensive and reliable review of the activist
publications of the US 'pro-family' movement, and as such, offers an insight into
the changing agenda of a movement that is growing both in organisational aptitude
and in global influence.




\section{Table of Contents}

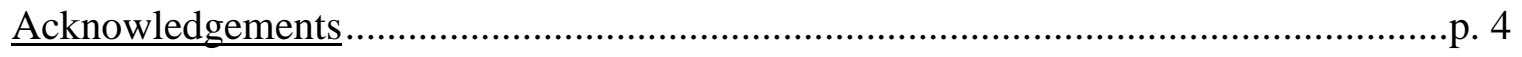

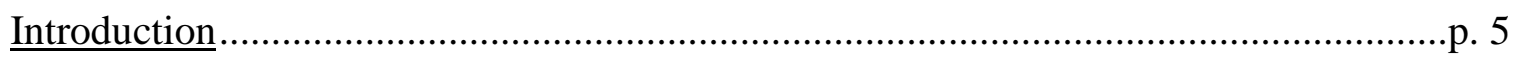

What is the 'pro-family' movement? .....................................................p. 12

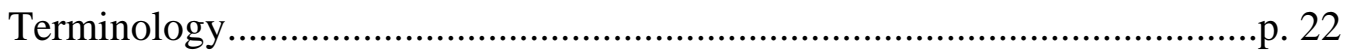

Chapter One: Understanding the emergence of the international 'pro-family'

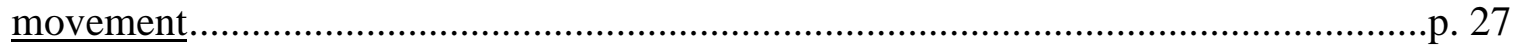

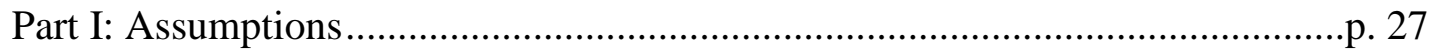

Part II: Understanding the international emergence of 'pro-family' groups ..........p. 34

Chapter Two: Methodology.................................................................................p. 58

Part I: Selection of 'pro-family' groups .........................................................p. 58

Part II: How the texts are used ...................................................................... 75

Chapter Three: 'Pro-family' views of Globalization: danger meets opportunity...........p. 88

Part I: How do 'pro-family' leaders interpret globalization?...............................p. 90

Part II: Globalization as redeemable..............................................................p. 109

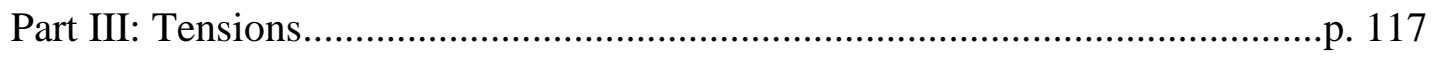

Chapter Four: The United Nations in 'pro-family' thought.........................................p. 123

Part I: How do 'pro-family' organisations characterise the UN? .......................p. 128

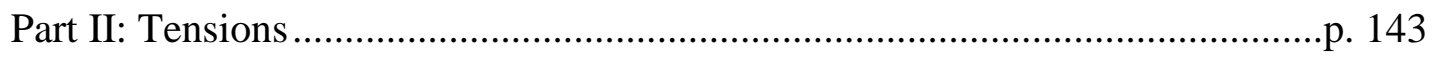

Chapter Five: Radicals and Basket-Cases: 'pro-family' characterisations of

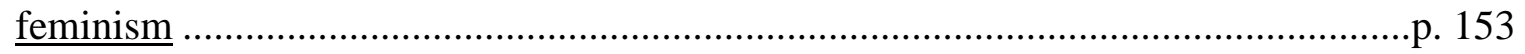

Part I: Characterisations of feminism in 'pro-family' texts ...............................p. 154

Part II: Tensions ..................................................................................... 178

Chapter Six: From 'population controllers' to 'demographic winter': the changing threat to fertility in 'pro-family' discourse …….......................................................... 187

Part I: Fertility in 'pro-family' discourse ........................................................p. 190

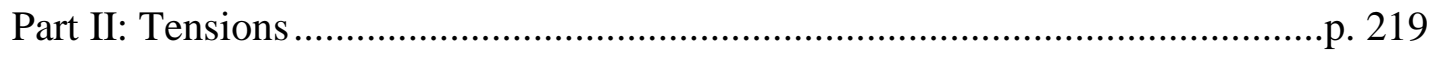

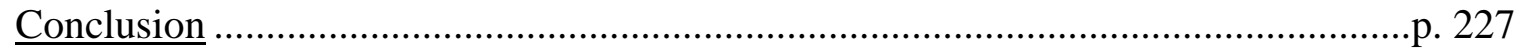

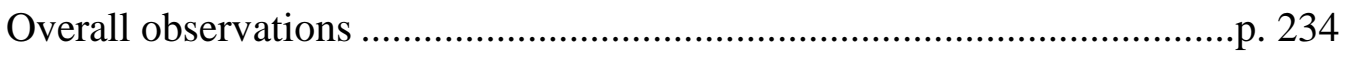

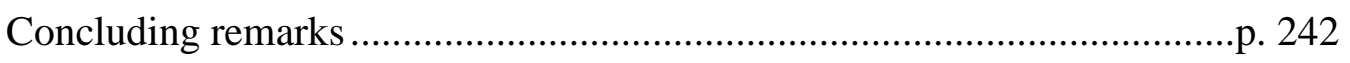

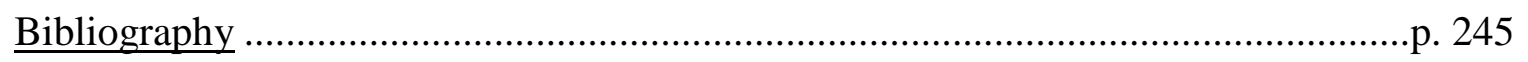




\section{Acknowledgements}

Thanks to my supervisors, my family and my friends. Thanks also to the Victoria University of Wellington philosophy department for all the coffee. 


\section{Introduction}

This thesis considers the changing agenda of a set of conservative organisations from the United States (US). These organisations have become major players in the global debate over sexual and reproductive rights. These groups identify themselves as 'pro-family' organisations, and have placed themselves in steadfast opposition to progressive organisations and officials who seek to make the enjoyment of these rights a universal norm. These 'pro-family' organisations are globally active and exert their influence at a number of different political levels around the world. They form chapters in different countries, lobby delegates at United Nations (UN) meetings, organise and attend international conferences, run courses, and commission and publish 'pro-family' research with the intention of shaping policy at the international level. Progressive women's rights advocates see the 'pro-family' movement as a major obstacle to achieving broad consensus over health and rights at the UN, and thus a serious impediment to making sexual and reproductive health services available to people in the global South. ${ }^{1}$ As described below, 'pro-family' organisations have been remarkably successful in their global activism.

Despite their effectiveness at the international level 'pro-family' organisations have struggled to achieve anything approaching their foreign policy successes within the US. Important as they are in the US political scene, free rein for sweeping 'profamily' change was confined to the international development portfolio during the Bush Administration. In some cases, the foreign policy changes won by "profamily' lobbying under Bush have meant that conditions imposed on US development funding have been entirely at odds with US law. Such discrepancies, however, have gone largely unnoticed in US domestic politics. As one observer notes, in confining the 'pro-family' agenda to the outside world, the Bush Administration has escaped criticism of policies which 'would be appalling to most moderate Republicans.'2

\footnotetext{
${ }^{1}$ In this thesis, I use 'global South,' 'third world' and 'developing' countries to describe the political and economic bloc of countries facing poverty, high levels of sovereign debt and experiencing relatively poor public health. While I acknowledge that 'developing countries' is a euphemistic and perhaps degrading term that depicts 'development' as a linear phenomenon, I retain the term where I believe it is appropriate, in order to maintain consistency with my primary texts. Where this is not the case, I use the term 'global South.' This is abbreviated to 'South' a number of times in the thesis.

${ }^{2}$ Jennifer Butler, quoted in Standaert, M. (2006) Skipping Towards Armageddon: the Politics and the Propaganda of the Left Behind Novels and the LaHaye Empire (New York: Soft Skull Press), p. 127-8.
} 
Though their real policy victories came with their favoured status under the second Bush government, 'pro-family' groups had emerged on the international scene well before this time. 'Pro-family' organisations had begun to network and exert some influence internationally during the Clinton Administration, with many gaining official UN Non-Government Organisation (NGO) status by the end of the 1990s. Thanks to their advocacy, advancement in the status of women's health and rights as a focus of development efforts at the international level had begun to stall. By the late 1990s, the entry of 'pro-family' organisations into the global NGO process and their successful networking with conservative states had made it difficult for feminist NGOs to claim that they spoke on behalf of the world's women. Progressive NGO representatives sensed that they were now defending previous gains rather than attempting to forge ahead with new goals. ${ }^{3}$

The 'pro-family' movement can be said to have emerged in the 1990s, coalescing in response to the Vatican's urgent appeal for conservative people of faith to come to the 1994 UN-sponsored International Conference on Population and Development (ICPD) in Cairo. A number of US 'pro-family' organisations arrived in Cairo to oppose women's rights activists in their efforts to have sexual and reproductive rights internationally recognised. ${ }^{4}$ At that conference, language around population control was largely dropped as a justification for the provision of reproductive health services in developing countries, in favour of rhetoric advancing women's reproductive health and rights. After Cairo, women's health and empowerment was to be an end, not a means, of development efforts.

More than anything else, for 'pro-family' organisations, feminist achievements at Cairo heralded an international right to abortion. This threat, more than anything else, brought the 'pro-family' movement out of the US. The groups gathered in greater numbers in Beijing in 1995, to try to prevent the gains made by feminists

\footnotetext{
${ }^{3}$ Butler, J. S. (2006) Born Again: The Christian Right Globalized (London: Pluto Press), p. 54.

${ }^{4}$ A number of commentators have noted that the discourse on family planning in development circles changed from 'population control' to 'reproductive rights' around this time. See for example, Eager, P. W. (2004) 'From Population Control to Reproductive Rights: Understanding Normative Change in Global Population Policy (1965 - 1994),' Global Society, vol. 18, no. 2, p. 151, and Grimes, S. (1998) 'From population control to "reproductive rights": Ideological influences on population policy.' Third World Quarterly, vol. 19, no. 3, p. 375.
} 
the previous year from being consolidated and extended at that year's World Conference on Women. 'Pro-family' organisations found themselves struggling against an overwhelming majority of progressive delegations and NGOs as they entered the UN arena. ${ }^{5}$ Alliances between conservative Catholics, Evangelicals and other faiths were forged at this time. ${ }^{6}$ Still largely taking its cue from the Vatican, the 'pro-family' movement grew in influence and experience during the 1990s. By the end of the 1990s, 'pro-family' organisations had become a globally active movement, enjoying increasing influence at the UN, with an agenda that had broadened beyond opposition to abortion to include a whole range of 'pro-family' concerns.

By the time George W. Bush was inaugurated as President in 2001, the 'pro-family' movement had an international agenda, experienced advocates, and established policy positions on development assistance and human rights. Enjoying the patronage of the UN's most powerful player, the 'pro-family' impact of US foreign policy positions would be a devastating blow to sexual and reproductive health and rights advocates. What follows is a brief list of 'pro-family' political achievements since 2001.

One of the major policy successes of 'pro-family' organisations was the Bush Administration's support and promotion of abstinence-only sex education. Abstinence-only education is based on the principle that the only way to prevent unplanned pregnancies and sexually transmitted infections (STIs) is to abstain from sex until marriage. Teachers of abstinence-only education are not permitted to mention birth control or condoms to their students, except to draw attention to the failure rates of different forms of contraception. Abstinence-only programmes teach students ways to refuse sex and deal with peer pressure, and lay emphasis on the importance of monogamy for the maintenance of a healthy society. ${ }^{7}$ One third of

\footnotetext{
${ }^{5}$ See Buss and Herman, Buss, D. and D. Herman (2003) Globalizing Family Values: the Christian Right in International Politics, (Minneapolis: University of Minnesota Press), p. 41.

${ }^{6}$ Ibid, p. 106-7, Butler, op. cit., p. 154.

${ }^{7}$ Barnett, J. E. and C. S. Hurst (2003) 'Abstinence education for rural youth: an evaluation of the Life's Walk program,' The Journal of School Health, vol. 73, no. 7, p. 264. Academic and peerreviewed studies broadly refute the effectiveness of abstinence-only education as a means of preventing unintended pregnancies and STIs. A 2006 review of US abstinence-only policies and programmes concludes that while there is widespread public support for abstinence as an essential and appropriate element of sex education, existing evaluations fail to show that abstinence-only
} 
the 2003 President's Emergency Plan For AIDS Relief (PEPFAR) funds for HIV prevention were reserved for 'abstinence-only-until-marriage' programmes. $^{8}$ In addition to this third, the remainder of PEPFAR prevention funds were made available to religious organisations, who may exclude information about condoms or contraceptives if they choose to do so.

Another 'pro-family' success came during the 2002 UN Special Session on Children. In this UN meeting, US delegates and their allies attempted to include language promoting abstinence-only education in the outcome document. Though they did not achieve this, the US delegation did manage to exclude reference to comprehensive sex education. One progressive commentator had this to say about the event: 'successfully opposing the mighty US proved to be possible, but it was an exhausting and bruising experience for all involved. ${ }^{9}$

Perhaps the most important policy achievement for 'pro-family' organisations was the restoration of the Mexico City Policy, a condition attached to US development assistance which stipulates that US Agency for International Development (USAID) funding must be withheld from any organisation that performs, refers, discusses or provides counselling for abortions, even when abortion-related activities are performed with the organisation's own funds. Despite the relative ease of access to abortion within the US, under Bush this 'pro-family' stipulation had the effect of isolating even moderately 'pro-choice' NGOs working in poor countries from their main source of revenue. Dubbed the 'global gag rule' because of the way it prevented discussion around abortion, critics of the policy say it created an

programmes have been effective in their stated goals. One study which did show that virginity pledges delayed sexual initiation, noted that when the pledger then did have sex, they were less likely to use contraception, and thus their postponement did not significantly decrease their chances of becoming unintentionally pregnant. See Santelli, J., M. A. Ott and M. Lyon et al (2006) 'Abstinence and abstinence-only education: a review of US policies and programs,' The Journal of Adolescent Health, vol. 38, no, 1, pp. 72-81, and Kirby, D. (2002) 'Do Abstinence-Only Programs Delay the Initiation of Sex Among Young People and Reduce Teen Pregnancy?' National Campaign to Reduce Teen Pregnancy, Washington DC, p. 4, available at http://www.thenationalcampaign.org/resources/pdf/pubs/abstinence_only.pdf [last accessed 15/07/09].

${ }^{8}$ For more on this stipulation, see Alrich, C. (2007) 'Abstinence Education Spending Requirement Hinders International Response to HIV/AIDS,' Guttmacher Policy Review, vol. 10, no. 2.

${ }^{9}$ Girard, F. (2002) 'UN Special Session on Children: Bush Administration Continues its Attacks on Sexual and Reproductive Health,' Reproductive Health Matters, vol. 10, no. 20, pp. 141-143. 
atmosphere of 'fear and intimidation' throughout USAID and its partner organisations around the world. ${ }^{10}$

'Pro-family' influence was also a key factor in Bush's decision to freeze the annual contribution of the US to the UN Fund for Population Assistance (UNFPA) in 2003. The funds were withheld on the basis of a US 'pro-family' think tank report which asserted that UNFPA was complicit in alleged coerced abortions in China. A US State Department investigation of the allegations found no evidence of UNFPA involvement in the provision of abortions or sterilisations, and recommended that the funds (already approved by Congress) be released to UNFPA immediately. Despite the official repudiation of the charges against UNFPA, the Bush Administration maintained the suspension of funds and continued to hold back funding for UNFPA. ${ }^{11}$

'Pro-family' organisations also managed to incorporate an anti-prostitution pledge as a condition of USAID funding for HIV prevention. The 'pro-family' view of sex work - as a form of slavery that prostitutes seek to escape - is incompatible with prevention programmes which call for non-judgmental approaches towards people who sell sex. ${ }^{12}$ In 2003, the US government announced a condition on US development assistance which stated that organisations receiving USAID funding to fight HIV/AIDS (outside the US) must sign a pledge confirming that they condemn prostitution and sex trafficking. This pledge, a condition of the Global AIDS Bill, was the product of intensive 'pro-family' lobbying. 'Pro-family' organisations' emphasis on sexual slavery as the most egregious form of human trafficking was a major aspect of their ability to present prostitution and trafficking as part of the

\footnotetext{
${ }^{10}$ Kaplan, E. (2004) With God on their Side: How Christian Fundamentalists Trampled Science, Policy and Democracy in Bush's White House (New York: The New Press), p. 229.

${ }^{11}$ Total funds withheld amounted to over $\$ 240$ million by the end of Bush's presidency. See UNFPA's 'Global Population Policy Update' no. 86, 26 January 2009, available at http://www.unfpa.org/parliamentarians/news/newsletters/issue86.html [last accessed 15/07/09]. ${ }^{12}$ Due to their high frequency of sexual contacts, sex workers require particular attention in the prevention of HIV, both for their own sexual health and in order to prevent or control epidemics. In populations where the virus is primarily spread through heterosexual intercourse, as it is in most of the countries where HIV is a serious problem, work with prostitutes is a significant aspect of prevention. Most successful HIV prevention programmes among marginalised groups have worked closely with prostitutes to build credibility and trust. See, for example, Koetsawang, S. (1999) 'A pragmatic intervention to promote condom use by female sex workers in Thailand,' Bulletin of the World Health Organisation, vol. 77, no. 11, pp. 888-895, and 'Making Prevention Work: Global Lessons Learned from the AIDS Control and Prevention (AIDSCAP) Project 1991-1997' available through: http://fhi.org/en/HIVAIDS/pub/Archive/index.htm [last accessed 11/08/09].
} 
same problem. As seen in other 'pro-family' achievements, many experienced organisations at the coalface of HIV prevention were cut off from their funds because they refused to conform to this rule. ${ }^{13}$ A key 'pro-family' leader cited this effort to 'follow the money' - cutting off non-compliant progressive organisations as one of the most important 'pro-family' victories that she had witnessed under the Bush administration. ${ }^{14}$

Finally, 'pro-family' organisations have been very active in opposing liberal language in the outcome documents of UN meetings and conferences. They work tirelessly to prevent the inclusion of terms in international agreements that could be construed to mean a right to services 'pro-family' groups believe should be restricted, or behaviours they deem immoral. From 2001 to the end of the Bush Administration, 'pro-family' organisations and leaders accompanied US officials, sometimes as members of the US delegation, advising them to oppose or attach reservations to particular terms or phrases in outcome documents. Terms such as 'reproductive health services,' 'sexual orientation' and 'sexual and reproductive rights' became the subject of bitter disputes at the UN, and less precise terms were adopted to preserve consensus. Efforts to improve the clarity of language in international agreements were seen as dangerous by progressive advocates: opening up debate on vague language risked the deletion of entire phrases or paragraphs from the agreement. ${ }^{15}$ These kinds of impasses were common during the Bush Administration, and outcome documents and compliance committees remained unclear as to the duties of the parties.

\footnotetext{
${ }^{13}$ This was particularly true of unionised sex workers, who overwhelmingly refused to sign the document and could no longer obtain US HIV prevention funds.

${ }^{14}$ Kaplan, op. cit., p. 225.

${ }^{15}$ An example of this is the effort by feminists to change the term 'access to reproductive health' to 'access to reproductive health services' in order to clarify which duties governments are obliged to perform in order to improve women's health. Under Bush, the US insisted on the use of the term 'reproductive health care' rather than 'reproductive health services' in documents. It is understood by both sides of the debated that 'services' is representative of a broader set of obligations than 'care,' including the right to information, contraception and abortion where it is legal. Ylva Bergman suggests that 'Services emphasize having control over one's sexuality and fertility and not just being cared for when sick or bleeding to death.' In one case, the outcome document asserts a 'right of access to reproductive health,' using neither care nor services. See Bergman, Y. (ed.) (2004) Breaking Through: A guide to sexual and reproductive health and rights,' The Swedish Association for Sexuality Education, Stockholm, available at http://www.rfsu.se/publications _rfsu.asp [last accessed 15/07/09].
} 
All of these 'pro-family' conditions were placed on development funds intended to improve the health and well-being of the world's poorest communities. US-funded organisations working in countries with the highest rates of HIV transmission, with the people least able to afford treatment to prevent the onset of AIDS, were the same organisations that were threatened with removal of their funding if they openly promoted the use of condoms. Maternal health NGOs working in subSaharan Africa - where in 1999, women had a one in sixteen chance of dying as a result of pregnancy ${ }^{16}$ - had to use teaching curricula that promote abstinence over contraceptives and stress the failure rates of condoms in order to continue to receive USAID funding. Organisations receiving USAID funding could not participate in their national abortion debates, even though abortion and freedom of speech are constitutionally protected rights in the US. 'Pro-family' victories in the development arena have been swift and substantial.

Whether or not they will ever be able to bring about these same policy changes within the US, 'pro-family' organisations are a movement of global significance. Either through the serendipitous election of a president sympathetic to their views, or through their achievement of a critical mass of organised enthusiasts (or a combination of both), globally active 'pro-family' groups represent a serious challenge to women's health and rights advocates. These 'pro-family' successes have been striking, not only because of the relative inexperience of the groups compared to their progressive opponents, but also because of their historical suspicion of international institutions. Given their former distaste for 'handouts,' 'big government' and international organisations, the speed and success of their entry into development politics is extraordinary.

With these accomplishments in mind, the broad impact of this movement calls for a thorough analysis of the motivations of US 'pro-family' groups at the global level. This is an undertaking that this thesis attempts to carry out. In doing so, I seek to do three related things: examine how the groups understand and frame the political world outside the US, show how this informs their changing agenda, and document

\footnotetext{
${ }^{16}$ See Garner, M. (1999) 'Death in the midst of life,' BBC News Online, Tuesday 29 June 1999, at http://news.bbc.co.uk/1/hi/special_report/1999/06/99/world_population/379943.stm [last accessed 15/07/09].
} 
if and how these understandings are changing over time. In other words, the aim of this thesis is to map the ideological framework of globally active 'pro-family' organisations, and show how this framework is changing. Before I do this, however, I discuss what I mean by the term 'pro-family.'

\section{What is the 'pro-family' movement?}

The 'pro-family' movement makes up only one part of the global issue-based activism pursued by US Christian Right organisations. Experts on the Christian Right highlight a growth in the movement's political interests outside the US since the end of the Cold War. Observers have focused on different subsets of the Christian Right in their attempts to understand the globalization of the movement. Correspondingly, experts identify broadly different motivations behind the activism of Christian Right groups as they extend their agenda, to use William Martin's words, 'beyond the water's edge. ${ }^{17}$

For this reason, in this thesis, I study 'pro-family' motivations separately from the other international concerns of the US Christian Right. Though the organisations may be 'in touch' with each other and share broadly similar views and sources of financial support, they are different people, promoting different causes and have increasingly divergent views of the world outside the US. Furthermore, distinguishing the diverse rallying cries of Christian Right advocacy groups may improve our understanding of what kind of impact 'pro-family' activism has on the Christian Right as a whole. ${ }^{18}$

In order to separate the 'pro-family' movement from other aspects of international Christian Right activism, I briefly discuss the other global issues to which US Christian Right organisations have applied themselves. International Christian Right activity and advocacy can be roughly divided into five categories: isolationism, support for Israel from 'Christian Zionist' lobby groups, worldwide evangelism and missionary commitments, opposition to religious persecution, and 'pro-family'

\footnotetext{
${ }^{17}$ Martin, W. (1999) 'The Christian Right and American Foreign Policy,' Foreign Policy, no. 114, p. 67.

${ }^{18}$ This might be done by using network or power structure analysis techniques, or comparative analysis, but is not attempted in this thesis.
} 
advocacy (the focus of this thesis). I briefly discuss each of these, highlighting tensions between the different issue areas.

\section{Isolationism}

This is the traditional approach Christian conservatives in the US have taken with regards to globalization, and it remains an enduring sentiment which threads through many of the texts examined in this thesis. Christian Right isolationism manifests itself as a "passional myth ${ }^{19}$ which sees the US as having a sacred history and Christian way of life, which requires protection from corrupting influences that come from outside. This extends to the protection of US industry, through what Christian Right observer Didi Herman refers to as the 'stoking [of] nativist and protectionist fires. ${ }^{20}$ Isolationism is also evident in the mistrust of external entities, especially communist countries and international institutions.

In her historical analysis of right-wing organisations in the US, Roads to Dominion, sociologist Sara Diamond suggests that opposition to government involvement beyond the US has been a part of the US conservative framework since the 1930s, and this sentiment has persisted to the present - though less vocally - despite the Japanese bombing of Pearl Harbour and other international entanglements. ${ }^{21}$ After the Second World War, Diamond writes that isolationist sentiment transformed into 'militant anticommunism,' a sentiment which she suggests has profoundly influenced the right-wing understanding of the world. ${ }^{22}$ She recalls that Patrick Buchanan ran his 1992 Republican Primary race with 'America First' as his catchphrase, evoking memories of the Right's 'isolationist roots. ${ }^{23}$ True to this core isolationist philosophy, some Christian Right organisations still have removing the

\footnotetext{
${ }^{19}$ This term is borrowed from Daniela Rossini, from a paragraph which describes this myth as "nostalgia for the "golden age" of isolation, a time when every American pursued his own personal interests without worrying about foreign affairs and the duties and responsibilities they implied.' Rossini, D. (1995) 'Isolationism and Internationalism in Perspective: Myths and Reality in American Foreign Policy,' in Rossini, D. (ed.) Theodore Roosevelt to FDR: Internationalism and Isolationism in American Foreign Policy (Edinburgh: Edinburgh University Press), p. 14.

${ }^{20}$ Herman, D. (2001) 'Globalism's Siren Song: the United Nations and International Law in Christian Right Thought and Prophecy,' the Sociological Review, vol. 49, no.1, p. 61.

${ }^{21}$ Diamond, S. (1995) Roads to Dominion: Right wing Movements and Political Power in the United States (New York: The Guilford Press), pp. 23-4.

${ }^{22}$ Ibid.

${ }^{23}$ Ibid, p. 23.
} 
US from the UN as their primary goal. ${ }^{24}$ Others act as UN 'watchdogs,' for example Phyllis Schlafly's Eagle Forum, whose mission is the protection of US sovereignty from the UN and other international institutions. ${ }^{25}$

As an explanation for the persistence of isolationism in contemporary Christian Right discourse, some authors suggest nostalgia for a bygone 'golden age' in which the US was relatively free from the complications of international affairs. ${ }^{26}$ Scholar and progressive activist Jennifer Butler suggests that the persistent conservative suspicion of the UN is partly a hangover from the Cold War; an enduring belief that the UN remains a stalking horse for communism. ${ }^{27}$ Despite the persistence of isolationism in some quarters, recent literature on the Christian Right acknowledges a movement away from isolationism as a guiding principle.

\section{Support for Israel}

Christian Right foreign policy concerning Israel is inextricable from beliefs about Armageddon and the Second Coming of Jesus. Experts on this topic stress the importance of pre-millennialism, the belief that the Second Coming of Christ is imminent, in understanding Christian Right support for Israel. ${ }^{28}$ For his part, Marsden writes that Christian Zionists (as he calls them) see events concerning Israel 'through an eschatological prism, indicating either God's displeasure or the proximity of the end of the age. ${ }^{29}$ Jerry Falwell famously summed up the Christian Right position on Israel: 'Whoever stands against Israel, stands against God., 30 Indeed, this 'Biblical focus' on Israel is widely held, according to former Republican Party strategist Kevin Phillips, who notes that 63 percent of white evangelical Protestants see the existence of the state of Israel as a requirement of

\footnotetext{
${ }^{24}$ One such campaign is called 'Get US out of the UN.' See www.getusout.net for more details [last accessed 17/12/2008].

${ }^{25}$ See http://www.eagleforum.org/ [last accessed 17/12/2008].

${ }^{26}$ See Diamond (1995), Martin, op .cit., p. 78.

${ }^{27}$ Butler, J. (2002) A New Sheriff in Town: The Christian Right Nears Major Victory at the United Nations, Public Eye, available at http://www.publiceye.org/magazine/v16n2/PE_Butler2.html [29/12/08].

${ }^{28}$ See for example, Herman op .cit., p. 66, and Croft, S. (2007), 'Thy Will be Done: The New Foreign Policy of America's Christian Right,' International Politics, no. 44, p. 698.

${ }^{29}$ Marsden, L. (2008) For God's Sake: The Christian Right and US Foreign Policy (London and New York: Zed Books), p. 184.

${ }^{30}$ Falwell, quoted in Brouwer et al, op. cit. p. 18. This quote also appears in Martin op cit, p. 72.
} 
prophecy to be fulfilled before Jesus will return. ${ }^{31}$ These evangelicals make up a sizable proportion of US citizens who support Israel. In his 2004 book, theologian Tim Weber notes that over a third of the Americans who support Israel say that they do so 'because they believe the Bible teaches that the Jews must possess their own country in the Holy Land before Jesus can return. ${ }^{32}$ To pursue this objective, there are a number of conservative Protestant NGOs in the US raising money with the purpose of using it to support Jewish migration to Israel. ${ }^{33}$

Nevertheless, the issue of Israel is problematic for the Christian Right in a number of ways. Many Jews themselves remain mistrustful of their allies' advocacy for Israel; in second coming scenarios of the Christian Right, Jews either convert to Christianity or they die a horrible death. ${ }^{34}$ Similarly, Marsden notes that Christian Zionists uniformly oppose Islamic regimes, ${ }^{35}$ unlike many in the 'pro-family' movement and the US government who are more inclined to work alongside Islamic governments and organisations to pursue conservative political goals. Furthermore, in his consideration of the rise of global Christianity, historian Phillip Jenkins warns that in the future, the issue of Israel may serve to isolate Northern Christians 'not just from Muslims, but from the rising churches of the South,' many of which are sympathetic to the plight of Palestinians. ${ }^{36}$ Nevertheless, despite the fact that it may hinder the pursuit of other goals at the international level, support for Israel remains an important aspect of Christian Right foreign policy.

\section{Worldwide evangelism}

As William Martin notes, by their identification with the very term 'evangelical,' US protestant evangelicals declare their desire to spread Christianity 'unto all the

\footnotetext{
${ }^{31}$ Phillips, K. (2006) American Theocracy: The Peril and Politics of Radical Religion, Oil and Borrowed Money in the $21^{\text {st }}$ Century, (London: Penguin Books), p. 364.

${ }^{32}$ Weber, T. (2004) On the Road to Armageddon: How Evangelicals Became Israel's Best Friends, (Michigan: Baker Academic), p. 11.

${ }^{33}$ See Croft, S. (2007), 'Thy Will be Done: The New Foreign Policy of America's Christian Right,' International Politics, Issue 44, p. 705-6. In his article, Croft reports on an 'Israel Outreach' organisation, which invites Evangelicals to 'step into the story,' by helping to fund Jewish immigration to their 'ancient homeland.'

${ }^{34}$ See Marsden, op. cit., p. 190, and Herman op. cit., p. 66, for more on the prophesied gruesome fate of non-Christians in end times scenarios.

${ }^{35}$ See Marsden, op. cit., pp. 197-198.

${ }^{36}$ Jenkins, P. (2007) The Next Christendom: The Coming of Global Christianity (New York: Oxford University Press), p. 213.
} 
world. ${ }^{37}$ This spread is taking place in no small measure. Marsden observes that the number of Christians in Africa has risen to nearly half of the continent's population; from 144 million in 1970 to 411 million in $2005 .{ }^{38}$ Over a third of these new African Christians belong to faith communities with value sets which are consistent with the conservative positions espoused by the US Christian Right. ${ }^{39}$ Religious scholar Timothy Shah demurs however, warning that these numbers should not be understood as a reflection of people in the South 'receiving' their religion from the US: the phenomenon, he argues, is largely indigenously led. ${ }^{40}$ Nor, he suggests should parallels between the moral views of US conservatives and Southern Christians be understood as important, as views on homosexuality and abortion tend not to constitute a central aspect of political life as they do in the US.

Nevertheless, widespread international evangelism is on the Christian Right agenda. In their book Exporting the American Gospel, Brouwer, Gifford and Rose document the rise of US missionary activity in the global South and the "Asian Tigers." These areas are comparable to the '10/40 window,' a missionary target observed by Sara Diamond, denoting the northern lines of latitude between which the vast majority of the world's non-Christians live. ${ }^{42}$ The targeting of Islamic people for conversion by evangelical Christians is an issue for Christian Right organisations who seek conservative Islamic support for 'pro-family' policies. ${ }^{43}$ Brouwer et al emphasise the complementary and connected nature of US political goals and the spread of conservative Christianity in the South.

It is not only Islamic people who are concerned about the evangelical Christian Right and their drive to 'win the world for Christ.' As Brouwer and his colleagues suggest, the successful efforts of evangelicals in the global South (and Africa in

\footnotetext{
${ }^{37}$ Martin, op. cit., p. 67.

${ }^{38}$ Marsden, op. cit., p. 76.

${ }^{39}$ Marsden offers opposition to homosexuality as an example. Among American Pentecostals, opposition to homosexuality runs at around 80 per cent, whilst amongst Nigerian and Kenyan Pentecostals, opposition is only marginally under 100 per cent. See ibid, p. 75.

${ }^{40}$ See Shah, T. S. (2004) 'The Bible and the Ballot Box: Evangelicals and Democracy in the "Global South," SAIS Review, vol. 24, no. 2.

${ }^{41}$ These are Hong Kong, South Korea, Singapore and Taiwan. See Brouwer, S., P. Gifford and S. D. Rose (1996) Exporting the American Gospel: Global Christian Fundamentalism (Routledge: New York and London).

${ }^{42}$ See Diamond, S. (1998) Not By Politics Alone: the Enduring Influence of the Christian Right (New York, The Guilford Press), p. 203.

${ }^{43}$ Butler (2006), op. cit., p. 134-5.
} 
particular) 'to convert Catholics to "real" Christianity' are a major problem for Catholic allies of the Christian Right. ${ }^{44}$ Proselytising evangelicals make much of the economic underdevelopment in developing countries, say the authors, attributing this to centuries of corruption, syncretism and weak religious leadership by the Catholic Church. ${ }^{45}$

Brouwer et al and Marsden see evangelism in poor countries as a form of 'soft power,' in which the vision of US prosperity attracts adherents in developing countries. ${ }^{46}$ If this is so, Christian Right missionary activism presents a view of progress that is compatible with earlier Christian Right views of development. Christian Right leaders had previously rejected involvement in development and foreign aid, because, they reasoned, poor countries were to blame for their own problems. These were ascribed to a lack of certain crucial values that encourage the accumulation of wealth, or in blunter terms, because of developing countries' 'addiction to paganism [and] immorality. ${ }^{47}$ In the promotion of self-sacrifice, hard work and submission to God as the means of achieving health and wealth in the global South, Christian Right proselytising offers a conservative alternative to rights-based models of development. As will be shown in later chapters, these values (particularly self-sacrifice) still inform the 'pro-family' understanding of how development ought to be pursued, in terms of what 'pro-family' groups see as their beneficial impact on individuals and communities.

\section{Freedom from Religious persecution}

As Marsden notes, persecution is 'a recurring theme throughout Christian history. ${ }^{, 48}$ Seen in the light of the increasing evangelical activity described above, it is perhaps unsurprising that globally active Christian Right groups have organised to combat the persecution of Christians beyond the US. A number of groups such as 'Stand Today,' 'International Christian Concern,' 'Bible League,' 'Christian Freedom

\footnotetext{
${ }^{44}$ Brouwer et al, op. cit., p. 216.

${ }^{45}$ Ibid, p. 217.

${ }^{46}$ For more on this, see Marsden, op. cit., p. 60.

${ }^{47}$ This perspective - a 'reconstructionist' one - is well described in Armstrong, K. (2007) On the Bible (New South Wales: Allen \& Unwin), p. 216.

${ }^{48}$ Marsden, op. cit., p. 115.
} 
International' and 'Voice of the Martyrs' are a part of the Christian Right effort to prevent Christian persecution around the world. ${ }^{49}$

Protecting Christians from execution in Sudan in the 1990s was a major rallying point for these Christian Right groups, with representatives claiming that over a million Christians had been killed in that country's turmoil, some reportedly by crucifixion. ${ }^{50}$ Opposition to persecution grew to be a principal aspect of evangelical foreign policy by 1996, when the National Association of Evangelicals appealed to the Clinton Administration to curtail development funds to any governments who were deemed to be persecuting Christians. ${ }^{51}$ Christian Right leaders organised a 'day of the persecuted Church,' which may have involved 100,000 congregations in the US by the second year it was held. ${ }^{52}$ Attention to this cause has also stimulated a flurry of interest in missionary activity in the late 1990s; by 2001, political scientist Stuart Croft reports, overseas missions organised by US Protestant organisations had increased by at least a factor of eight from their number in $1996 .{ }^{53}$ That areas deemed by the Christian Right to be rife with religious persecution are the same countries that are targeted for proselytising has not gone unnoticed by critics of the Christian Right. ${ }^{54}$ As Marsden observes, the Bush Administration's increased attention to this issue has enabled evangelistic Christian Right organisations opportunities to proselytise in areas to which they previously had no access. ${ }^{55}$

Though much of the focus has been on persecution of Christians under Islamic regimes, China has also been a target of Christian Right anti-persecution groups. A number of Christian Right groups lobbied the Clinton administration in an attempt to block China's 'most favoured nation' trading status in $1997 .{ }^{56}$ For the most part, however, efforts against Christian persecution have portrayed Islamic governments

\footnotetext{
${ }^{49}$ See http://www.standtoday.org/, http://www.persecution.org, http://www.bibleleague.org/persecuted/index.php, http://www.christianfreedom.org/, and http://www.persecution.com/ [all accessed 3/12/2008]. See also Marsden op. cit., p. 119 and Croft, op. cit.

${ }^{50}$ For more on this, see Martin, op. cit., p. 75 and Croft, op. cit., p. 695.

${ }^{51}$ See Diamond (1998), op. cit., p. 207. Christian Right activists organised a conference in 1996 entitled 'the global persecution of Christians;' for more on this, see Croft, op. cit., pp. 694-5.

${ }^{52}$ Croft, op. cit., pp. 694-5.

${ }^{53}$ Ibid, p. 695.

${ }^{54}$ See Diamond (1998) in particular, but also Croft (2007) and Marsden (2008).

${ }_{55}^{55}$ Marsden, op. cit., p. 121.

${ }^{56}$ Martin, op. cit., pp. 75-6.
} 
and groups as the chief culprits of this form of violence. According to Croft, some Christian Right groups even attempted to frame the events of September the $11^{\text {th }}$, 2001 as part of an ongoing 'jihad' against 'Americans, Christians and Jews.' ${ }^{57}$ This effort was broadly unsuccessful, however, as the ensuing 'war on terrorism' allied the Bush Administration with the very governments these Christian Right organisations had been accusing of persecution: Sudan, Saudi Arabia, Egypt, Uzbekistan and Pakistan. ${ }^{58}$

The Bush Administration was not alone in its selective understanding of its duty to prevent religious persecution: the 'pro-family' segment of the Christian Right also made an effort to achieve some distance from this issue. Law professors Doris Buss and Didi Herman's interviews with prominent 'pro-family' leaders reveal that to a large degree, 'pro-family' leaders accept the political expediency of working with the very governments their anti-persecution Christian Right compatriots despise. Austin Ruse, leader of the Catholic Family and Human Rights Institute (C-Fam), states frankly: "we do not work on religious freedom, we work on life and family., In the same interview, Ruse goes on to say that he and other 'pro-family' leaders 'work very well with [Sudanese and Libyan UN delegations], at the same time having revulsion for the things that they are doing to Christians in their own countries. ${ }^{60}$ Rather than characterise this as hypocritical, Buss and Herman prefer to see Ruse's nonchalance in this area as a blend of political compromise with a willing 'suspension of disbelief. ${ }^{61}$ While it is unclear how much belief Ruse is choosing to suspend, so to speak, the extreme and open pragmatism with which he operates is an indication of how disparate the Christian Right movement is. Moreover, it shows the degree to which Ruse and his 'pro-family' associates are unwilling to be sidetracked from their cause, recognising the need for Islamic allies.

\section{The 'pro-family' movement}

As has been shown here, there are several reasons to consider the 'pro-family' movement separately from other Christian Right issue areas. As noted, 'pro-family'

\footnotetext{
${ }^{57}$ Croft, op. cit., p. 697.

${ }^{58}$ See ibid, p. 697, and Marsden, op. cit., pp. 123-4.

${ }^{59}$ Austin Ruse, quoted in Buss and Herman, op. cit., p. 95.

${ }^{60}$ Ibid, p. 96.

${ }^{61}$ Ibid, p. 96.
} 
organisations collaborate with those same governments that their Christian Right allies accuse of persecuting Christians and threatening Israel. Politically, 'profamily' groups are more autonomous from Christian denominational divisions and the Republican Party than the other internationally active Christian Right organisations discussed above. Because of this, 'pro-family' groups are freer to ally with Catholic, Mormon and Islamic organisations - what others in the Christian Right might consider to be 'a pact with Satan' - in order to pursue shared goals.

More than the other parts of the Christian Right, the 'pro-family' movement is a part of what Keck and Sikkink classify as a 'transnational advocacy network. ${ }^{92}$ By attempting to work with a variety of international conservative organisations and seeking to create a permanent bloc of 'pro-family' government delegates at the UN, the 'pro-family' movement pulls itself further away from its domestic base and other international causes of the Christian Right.

In terms of their ideological commitments, 'pro-family' groups have a deeper commitment - at least rhetorically - to reducing poverty and improving people's well-being (in measurable ways) than the other internationally active sectors of the Christian Right discussed here. This is likely to be related to the influence of conservative Catholic organisations on the 'pro-family' movement, with their connection to a church which has a history of building hospitals, organising famine relief and working to relieve poverty in developing countries.

At the policy level, at least, unlike the other issues of importance to the Christian Right, the 'pro-family' movement's focus is on human bodies as much as it is on human souls. The focus on physical rather than spiritual well-being has led to the emergence of 'pro-family' think tanks, which research and produce a 'pro-family' form of social science. This development can be read as a broader attempt to break the secular monopoly on health and human rights language, and social science in general. The emergence of what Buss and Herman call Christian Right 'expert discourse ${ }^{63}$ has been politically useful, providing US policy makers sympathetic to

\footnotetext{
${ }^{62}$ Keck, M. E. and K. Sikkink (1998) Activists Beyond Borders: Advocacy Networks in International Politics, (Ithaca and London: Cornell University Press).

${ }^{63}$ Buss and Herman, op. cit., pp. 7-9.
} 
'pro-family' views with the justifications required to advance 'pro-family' policies, as has already been shown in this chapter.

Most obviously, perhaps, 'pro-family' organisations hold a view of the UN that distinguishes them from the rest of the Christian Right. In fact, it seems to be the case that 'pro-family' groups' reputations rely to some degree on their acquisition of NGO status at the UN. ${ }^{64}$ Rather than hold the UN in disdain, as is common in the broader US conservative framework, ${ }^{65}$ 'pro-family' organisations are deeply involved in the UN system, and use it as a platform to press for conservative social policies. This effort betrays a belief in the UN which is absent from other Christian Right organisations, and also a conviction that their social agenda is widely supported by delegates in the majority of nations.

Moreover, the language with which 'pro-family' organisations advocate for their policies is far more secularised than that of other international Christian Right groups. As Swinski finds in her doctoral dissertation on conservative movements at the UN, 'pro-family' groups have adjusted the way they represent their views, from tradition to rights, and now use science and reason rather than religion and morality, to advance their arguments. ${ }^{66}$ Explicit discussion of religion is carefully managed, and in many cases, wholly avoided. ${ }^{67}$ 'Pro-family' organisations appear to be satisfied that their policies require no explicit appeal to religious principles.

Lastly, these groups are globalizing in a way that is different from the other groups. 'Pro-family' organisations are attempting to broadcast their conservative agenda as a universal blueprint for good development, rather than a movement that serves the interests of Christians, or citizens of the United States.

The globalization of 'pro-family' organisations should not be understood in isolation from other Christian Right activities, in that success or failure in one area may influence - and be influenced by - other areas of concern to the movement.

\footnotetext{
${ }^{64}$ Marsden op. cit., p. 137.

${ }^{65}$ Butler, op. cit. p. 136.

${ }^{66}$ Swinski, J. S. (2007) Adapting to Norms at the United Nations: Abortion-Rights and Anti-Abortion Networks (Dissertation). University of Maryland, available at https://drum.umd.edu/dspace/handle/1903/7634?mode=full. [last accessed 13/10/08].

${ }^{67}$ Buss and Herman note that '... despite religious belief being the basis for the WCFII alliance,' the outcome document fails to provide 'any theological guidance whatsoever,' op. cit., p. 89-90.
} 
Christian Right organisations are informed by similar media and do advocate for similar foreign policies overall, but their ability to present a united front at the international level has been limited.

The agenda of 'pro-family' organisations diverges from that of other Christian Right groups. Consequently, while I acknowledge that the Christian Right political power base in the US is, in theory, the same for all internationally active Christian Right organisations, I propose that inconsistencies and in-fighting may not require resolution. This is because, in practice, 'pro-family' groups' devotion to their particular international concerns has been paramount. 'Pro-family' international activities are not widely broadcast to the US public and tend to be funded in different ways from domestic causes: in one case in particular, a prominent 'profamily' organisation's international activity relies on a single donor. ${ }^{68}$ One "profamily' activist disclosed that he had received 'hate mail' from other international Christian Right organisations. ${ }^{69}$ Considering the activism of 'pro-family' organisations separately from other globally active Christian Right organisations also helps to define the particular characteristics of the 'pro-family' movement.

\section{$\underline{\text { Terminology }}$}

Although I consider a very similar set of Christian Right groups that Buss and Herman term the 'CR UN' - Christian Right groups active at the UN - I refer to the groups under scrutiny here as 'pro-family' organisations, or the 'pro-family' movement. ${ }^{70}$ The reason for this is that I see the international efforts of these groups as extending well beyond their activity at the UN, in that they are attempting to create a conservative global movement which is intended to affect political debates at many levels.

Croft uses the term 'conservative Protestants' in his discussion of Christian Right foreign policy, but because Catholic and Mormon organisations are a part of the international 'pro-family' movement, I require a more inclusive term. In addition,

\footnotetext{
${ }^{68}$ This group is Concerned Women for America. See Marsden, op. cit., p. 140.

${ }^{69}$ Austin Ruse reports that 'pro-family' activists have received hate mail for forging alliances with Islamic groups and governments. See Buss and Herman, op. cit., p. 95.

${ }^{70}$ In the chapters that follow, the term 'pro-family organisations' should be understood as US 'profamily' organisations.
} 
these groups are acting in a number of ways that are not conservative. Their attempt to dramatically change the status quo (though they claim they want to change it 'back' to a presumed better past) is perhaps the most obvious example of this, but their increasingly novel international activity, such as their new alliances with old nemeses, is also an important reason to avoid the label 'conservative.'

Another option would be to simply call these groups the Christian Right, as Butler does. Yet this nomenclature does not capture the specific focus of 'pro-family' groups, which is the curtailment of sexual and reproductive rights, the central concern of this thesis. Marsden also uses the term Christian Right, and includes conservative Catholics and Mormons as Butler and Buss and Herman do. The main qualifying characteristic for belonging to the Christian Right in Marsden's work is 'the common denominator' of 'social and fiscal conservatism.' ${ }^{71}$ While this definition works in the broader purview of Christian Right foreign policy, it fails to capture the absolute priority which 'pro-family' groups assign to social policy: fiscal conservatism comes a distant second to social conservatism. Moreover, these groups are involved in deciding how development monies ought to be distributed, rather than whether they ought to be.

International 'pro-family' organisations can be considered a subset of the Christian Right, and include conservative Catholic and Mormon organisations. Including Catholics in the 'pro-family' movement is conventional. As Buss and Herman note, despite some awkwardness between conservative Protestants and Catholics within the US, the organisations work well together in terms of their international activity, ${ }^{72}$ and have done so for some time. Croft does not include Catholics in his analysis, but that may again be a result of his focus on foreign policy, in which positions of Protestants and Catholics clearly clash, for example, on the issue of Iraq.

Finally, in her discussion of how to label US conservatives in Roads to Dominion, Diamond acknowledges William Hixson's caution that 'it is a good rule not to grant

\footnotetext{
${ }^{71}$ This definition also fails to make a distinction between the Christian Right and the neo-conservative movement. Marsden, op. cit., p. 5.

${ }^{72}$ Buss and Herman, op. cit., p. xviii.
} 
final authority over the use of words to those whose interests are served by them. ${ }^{, 73}$ Christian Right NGOs certainly believe the term 'pro-family' serves them. Butler notes the popularity of the term, with these groups choosing most often to identify their activities as 'pro-family,' which she suggests is 'perhaps is the most unifying aspect of Christian Right activism, and the one that resonates in other parts of the world, in particular the Muslim world. ${ }^{74}$ By applying this name to themselves, 'pro-family' organisations imply that their opponents are 'anti-family.' Yet the names that social movements give themselves are never politically neutral, nor are they intended to be. In using the term 'pro-family' as representative of the groups I seek to understand, I accept their sincerity in the belief that they are working in the best interests of the family, as they define it. I retain the word in quotations throughout this thesis because I do not accept that the work these groups do is necessarily in the best interests of families, nor do I accept that their definition of the term 'family' is a universally true or useful one. However, since this thesis is an attempt to understand the changing ideological framework of this movement, I have chosen terminology that allows for a close reading of the way these groups consider themselves, yet preserves a degree of analytical distance.

I use the terms 'movement' and 'social movement' to describe the activism of 'profamily' organisations because 'pro-family' organisations are 'reach[ing] beyond the customary resources of the social order to launch their own crusade against the evils of society, ${ }^{75}$ to use John Wilson's definition. Although 'pro-family' groups do not fit any one category of David Aberle's 1966 analysis of social movement types (or Wilson's 1973 development on Aberle's classifications), there are elements of all four types present in 'pro-family' activism. ${ }^{76}$ The 'pro-family' movement is 'transformative' (or 'revolutionary'), in that the organisations anticipate enormous change, seeking to overhaul modern social structures and remake them in the image of the 'natural family.' It is 'reformative' in its issue-based activism and its efforts

\footnotetext{
${ }^{73}$ Hixson, W. B. (1992) Search for the American Right Wing: An Analysis of the Social Science Record, 1955-1987 (New Jersey: Princeton University Press), p. xvii.

${ }^{74}$ Butler (2006), op. cit., p. 18.

${ }^{75}$ John Wilson, quoted in Cohen, R. and S. M. Rai (2000) 'Global Social Movements: towards a cosmopolitan politics,' in Cohen, R. and S. M. Rai, (eds.) Global social movements (New Jersey: Athlone Press), p. 3

${ }^{76}$ Aberle, D. F. (1966) The Peyote Religion among the Navaho (Chicago: Aldine Publishing Company), and Wilson, J. (1973) Introduction to Social Movements (New York: Basic Books).
} 
to 'protect' women and families in the global South. It is 'redemptive' in that the personal evangelicalism or religious conversion of individuals has the potential to bring about sweeping social change in the 'pro-family' mindset. Lastly, the movement is 'alternative' in its countercultural emphasis on a particular lifestyle.

Buss and Herman do not classify Christian Right groups active at the UN as a global or transnational 'social movement' (preferring to see them as a subset of the Christian Right) but they believe they have 'the makings' of one. I suggest that the 'pro-family' movement's sustained global efforts fit Sidney Tarrow's definition of a social movement, as 'collective challenges (to elites, authorities, other groups or cultural codes) by people with common purposes and solidarity, in sustained interactions with elites, opponents and authorities. ${ }^{, 7}$ The 'pro-family' movement can thus be thought of as a continuous challenge to a wide array of opponents or ideas which its members perceive as threatening the 'natural family,' a concept I discuss in detail in the following chapter.

\section{Structure}

In this thesis, I search for the different ways that the global environment and its actors are discussed in 'pro-family' discourse. I organise texts from the websites of a number of organisations which are representative of the 'pro-family' movement into four areas which I see as important signposts in the 'pro-family' view of the world outside the US. These are globalization, the UN, feminism, and fertility. All four areas of focus also represent justifications that 'pro-family' organisations provide for their activities beyond the US.

Understanding the 'pro-family' view of globalization is the focus of chapter three, and sets the context for the chapters that follow. The UN demands special attention because it has been instrumental both to the way the organisations have characterised the political world outside the US, and to the 'pro-family' entry into development politics. 'Pro-family' views of the UN are the focus of chapter four. Opposing feminism stands out as one of the main justifications for 'pro-family' activity at the global level, and has been a key aspect of the international 'pro-

\footnotetext{
${ }^{77}$ Tarrow, S. (1994) Power in Movement: Collective Action, Social Movements and Politics (New York: Cambridge University Press), p. 2.
} 
family' agenda since Cairo. The way feminism is portrayed in 'pro-family' discourse is described and analysed in chapter five. Fertility, discussed in chapter six, persists as a key interest of 'pro-family' organisations as they make sense of the international politics around women's health and rights. My research attempts to show how some of these depictions are shifting over time, and where appropriate, explanations as to why this may be occurring. These shifts often involve costs or complications and these are discussed at the end of each chapter.

The world outside the US has been on the 'pro-family' radar for 15 years; my research shows the way global entities and ideas have been framed by 'pro-family' organisations and how this is changing over time. I consider 'pro-family' discourse from 1997 and extend my analysis to the end of 2008 to consider the changing ideological framework of the 'pro-family' movement. Before I proceed to these research chapters, however, I evaluate the contributions of literature on the ideologies of international 'pro-family' groups, and discuss the methodology I use to analyse 'pro-family' texts. 
Chapter One: Understanding the emergence of the international 'pro-family' $\underline{\text { movement }}$

'Ideas have consequences.',

Allan Carlson, the Howard Center for Family, Religion and Society, 2000

This chapter critically reviews the literature offered to explain the emergence and continued activism of 'pro-family' groups beyond the US. The first part of this chapter discusses three assumptions I make which direct my examination of "profamily' ideology. The remainder of this chapter describes and evaluates the different ways that observers of the international Christian Right have approached this issue.

Observers of the Christian Right draw on a number of different ideas about the nature of the 'pro-family' movement (and globalization itself) to understand the global emergence of 'pro-family' groups. In this chapter, the strengths and weaknesses of each of their arguments are analysed in terms of their coherence, veracity and usefulness. This chapter also discusses the other aspects of "profamily' international expansion that other authors in the field deem vital to understanding the movement.

\section{Part I: Assumptions}

The first assumption I make is that the 'natural family' is the centrepiece of 'profamily' activism. While the set of moral ideas encapsulated by this term have not always been labelled in this way in Christian Right discourse, the 'natural family' refers to a set of norms and beliefs about sexual and reproductive behaviour about which 'pro-family' organisations have agreed since well before their international emergence.

The second assumption is to do with the ways that understandings of globalization affect the behaviour of international organisations. By this I mean that the way that

\footnotetext{
${ }^{1}$ Carlson, A. (2000) "“The family” at the United Nations: what went wrong?' The Howard Center for Family Religion and Society, The Family in America, vol. 14, no. 8, available at http://www.profam.org/pub/fia/fia 1408.htm [last accessed 06/09/09].
} 
the changing world is discussed within 'pro-family' discourse is intimately connected to how the organisations decide what to do, as they pursue their 'natural family' politics at the global level.

The last assumption, which is connected to the previous one, is that participating in global debates changes actors. Successful interaction between actors in the international 'pro-family' network calls for a relaxation of certain ideological tenets held by organisations of the domestic Christian Right. Each of these three assumptions is discussed and justified below.

\section{The 'natural family'}

Not all family arrangements are morally equal in the 'pro-family' vision. The 'natural family,' consisting of a married man and woman and their biological offspring, is a central platform for 'pro-family' advocacy. 'Pro-family' scholars agree that for the purposes of 'sharing love and joy, propagating children, providing their moral education, building a vital home economy, offering security and binding the generations,' the 'natural family' is the ideal social unit. ${ }^{2}$

In addition to its ability to produce positive social outcomes, 'pro-family' groups advocate that the 'natural family' is the fundamental social unit described in Article 16 of the UN Declaration of Human Rights. Among other things, the declaration states that 'men and women of full age, without limitation due to race, nationality or religion, have the right to marry and to found a family,' and that 'the family is the natural and fundamental group unit of society and is entitled to protection by society and the State.' 3 From this, 'pro-family' activists see the heterosexual married couple and their children as the fundamental social unit protected by this definitive UN human rights document. Deviations from this, in the 'pro-family' view, are not to be encouraged by countries who uphold this declaration.

\footnotetext{
${ }^{2}$ This is an extract from 'The Natural Family: a Manifesto,' quoted in Carlson, A. (2005) 'Defining Family Friendly,' Remarks for a public dialogue co-sponsored by the Sutherland Institute and the Hinkley Institute of Politics, The University of Utah, 23 September 2005, available at http://www.profam.org/docs/acc/thc.acc.dfu.050923.htm?search [last accessed 29/07/09].

${ }^{3}$ From the Universal Declaration of Human Rights, available at http://www.un.org [last accessed 29/07/09].
} 
'Pro-family' intellectuals acknowledge that societies cannot universally achieve this ideal. 'Tragedies alone,' writes one commentator, 'such as the premature death of a young parent, mean that the ideal will always be tempered by the reality. ${ }^{4}$ With these kinds of situations in mind, 'pro-family' activists call on public servants to draft policies that both deal with shortfalls (without encouraging them) and maintain a focus on protecting 'the natural family' as the primary goal of social policy. Not only is membership in such a family a human right, according to "profamily' activists, it is also a cure for social disorder. According to a prominent 'profamily' intellectual, the 'natural family' has become a key term behind which a variety of conservative religious organisations with different agendas can rally. ${ }^{5}$ The 'natural family,' then, is both a rhetorical tool for conservative policymakers, and an ideological symbol affirming the moral foundations of the 'pro-family' movement.

The 'natural family' and its role in animating international Christian Right politics is thoughtfully analysed by Buss and Herman in their groundbreaking book, Globalizing Family Values. These authors identify the Christian Right's emphasis on this particular type of family as a 'new family theology.' In their view, the 'natural family' has two key elements: marriage and heterosexuality. ${ }^{6}$ They suggest that the prefix 'natural' has arisen as an aspect of Christian Right counter-discourse, in opposition to feminism and gay rights activism. This type of family (which until recently, say 'pro-family' activists, never needed to be defended) has been rebranded in opposition to "new foes. ${ }^{, 7}$ Moreover, they add, God is now implicated in the creation and blessing of the 'natural family.' Because the biological family is 'natural,' say Buss and Herman, Christian Right scholars see it as 'God-given,' and

\footnotetext{
${ }^{4}$ Carlson, A. (2005) 'Beyond the Culture War: On the Natural Family: A Manifesto,' Concerned Citizens for America town hall meeting, 20 October 2005, Central Christian Church, Rockford, Illinois, available at http://www.profam.org/docs/acc/thc.acc.cca.051020.htm [last accessed 29/08/09].

${ }^{5}$ Allan Carlson, interviewed by (then) doctoral student June Samuel Swinski, reflecting on the achievements of the 'pro-family' networking around the time of the second WCF in 1999. Swinski, J. S. (2007), Adapting to norms at the United Nations: the abortion-rights and anti-abortion networks, (dissertation) University of Maryland. Available through https://drum.umd.edu/dspace/handle/1903/7634?mode=full [last accessed 13/10/08], p. 219.

${ }^{6}$ See Buss, D. and D. Herman (2003) Globalizing Family Values: the Christian Right in International Politics, (Minneapolis: University of Minnesota Press), p. 5.

${ }^{7}$ Ibid, pp. 2-4.
} 
because it is 'God-given,' it is by definition 'natural. ${ }^{8}$ Given that many 'profamily' publications which spell out the exact role of the 'natural family' in Christian Right politics were released after Buss and Herman's 2003 book, their early interest in this topic shows considerable foresight. They astutely connect this new way of opposing homosexuality and abortion to the increase in scholarly research supporting Christian Right political activism.

To these observations, I would add that the 'natural family,' has become the primary 'pro-family' justification for the marital containment of sexuality. According to a 'pro-family' declaration, 'marriage between a man and a woman forms the moral context for sexual union' and sex outside of the context of 'traditional' marriage is a 'deviation from natural sexual behaviour.' ${ }^{9}$ The "natural family,' then, is a way of reiterating or translating older conservative ideas about sexual morality into a new kind of political discourse, which 'pro-family' groups sense is more appropriate to their current rhetorical requirements. Most importantly, the 'natural family' captures the sexual morality upon which 'pro-family' discourse rests, and around which 'pro-family' activists coalesce.

The way 'pro-family' organisations understand globalization influences their behaviour

A significant part of this thesis is concerned with the 'pro-family' approach to globalization, and the political world beyond the US, and how this is changing over time. I take it as a given, then, that 'pro-family' understandings of the world influence the way that the organisations behave in it, and vice versa. This may appear a somewhat trite observation. Yet it is an important one, in that it underscores the importance of looking at 'pro-family' understandings of the world as a means of appreciating their agenda, rather than simply observing their behaviour and the goals they achieve.

The dynamic nature of 'pro-family' global activism is also an important aspect of this assumption. Like all institutions, 'pro-family' organisations are encouraged by

\footnotetext{
${ }^{8}$ Ibid, p. 5.

${ }^{9}$ See 'Mexico 2004: the Mexico City Declaration' at http://www.worldcongress.org/WCF3/wcf3 dec.htm [last accessed 29/07/09].
} 
successes in some areas and discouraged by failures in others. These successes and failures influence the way that 'pro-family' groups characterise their opponents and the context of their battles, and this, in turn, informs their next endeavours. From these kinds of interactions, an observer can discern a changing agenda that is influenced by the outside world, as well as influencing other actors at the same time.

This becomes especially important in the context of globalization. In discussing how religious movements fare under globalization, James Beckford posits a twoway relationship between a movement's understanding of globalization, and its attempts to use the phenomenon for its own particular purposes. ${ }^{10}$ In Religion and Globalization, Peter Beyer discusses this kind of relationship in terms of creating and destroying identities, but like Beckford, sees the usefulness of certain identities (and I would argue, agendas) as a key component of change under globalization:

‘...the global system corrodes inherited or constructed cultural and personal identities, yet also encourages the creation and revitalisation of particular identities as a way of gaining control over systemic power. ${ }^{11}$

It is not just the identities of the actors themselves that are changed to suit the political agenda of the participants; the way ideas and organisations in the global realm are characterised is also related to political efforts to gain influence in the global arena. How social movements understand global entities and systems affects, in an important way, the way they advance their causes.

For this reason, I suggest that 'pro-family' understandings of globalization are more important in this kind of undertaking than pinning down what globalization is or is not. It would thus be a mistake to produce a definition of globalization here. My goal is not to show how 'pro-family' organisations understandings differ from objective reality as I render it; rather it is to convey what they understand to be global realities, and how these are changing over time. In other words, I suggest that the 'pro-family' agenda needs to be examined with an acknowledgement of the changing ways 'pro-family' activists depict globalization and the global world.

\footnotetext{
${ }^{10}$ Beckford, J. (2000) 'Religious Movements and Globalization,' in Cohen, R., and S. Rai, (eds.) Global social movements (New Jersey: Athlone Press), p. 173.

${ }^{11}$ Beyer, P. (1994) Religion and Globalization (London: Sage), p. 3.
} 


\section{Acting globally pulls 'pro-family' groups away from their domestic base}

As noted in the previous chapter, Buss and Herman see the internationally active groups as such a distinct category that they provide a label for the subset of Christian Right groups active at the UN: the 'CR UN.' They offer two main justifications for separating them from their domestic base: the international groups' activism at the UN (an organisation the domestic Christian Right tends to view with suspicion); and the international Christian Right's alliances with Islamic 'pariah' states. $^{12}$

Butler develops this observation further, by noting that this segment of the Christian Right - initially hostile to the UN - now actively presses for its own agenda through the General Assembly. 'Each new success,' observes Butler, 'has gradually moved Christian Right organisations to a higher level of engagement and investment in the UN as an institution.' ${ }^{13}$ As the UN is characterised by a culture of liberal interaction, 'pro-family' organisations have adjusted their conduct in order to be successful in that context. ${ }^{14}$ Keck and Sikkink put it thus: 'Modern networks are not conveyor belts of liberal ideals but vehicles for communicative and political exchange, with the potential for mutual transformation of participants. ${ }^{, 15}$ Although the same culture of liberal interaction is arguably true of US domestic politics to some degree, international 'pro-family' organisations are clearly diverging from their domestic base in terms of ideology.

\footnotetext{
${ }^{12}$ Buss and Herman, op. cit., pp. xx-xxi.

${ }^{13}$ Butler, J. S. (2006) Born Again: The Christian Right Globalized (London: Pluto Press), p.51.

${ }^{14}$ Quoting Fiona Adamson, June Swinski writes that "Political entrepreneurs who promote norms that do not conform with the dominant liberal institutional culture of international organizations will have to adjust their normative claims or draw on other institutional infrastructures...” In characterising the political norms of the UN, Swinski suggests that they can be seen as a form of Lockean liberalism, because they have an 'emphasis on individual liberties, a rights-based framework for developing policy, and progress through science and reason, [ideals] embodied in the procedures and frameworks of UN global conferences in several ways: first, individuals are so important that collective decisions must be consensus decisions (Boli and Thomas 1999), making coalition building necessary; second, the rights framework has become so embedded that it is a legitimising frame for most social issues, especially in the post-Cold War world (Rajagopal 2003); and third, science and reason are seen as the most legitimate methods of justifying policy and action, as opposed to religion and tradition (Thomas 2001).' Swinski, op. cit., p. 61-2.

${ }^{15}$ Keck, M. E. and K. Sikkink (1998), Activists Beyond Borders: Advocacy Networks in International Politics (Ithaca and London: Cornell University Press), p. 214.
} 
Social movements that are able to adapt to new political processes and expectations are more likely to persist as influential actors in a new environment. In this context, the ability to influence political outcomes will depend on advocates' abilities to learn from their experiences, and change certain views or the way they frame their arguments to suit their environment. For example, in 2003, Buss and Herman offer evidence that the Christian Right viewed global space as controlled by its antiChristian enemies, who are working together to "undermine the "natural family" and ... religious belief itself., ${ }^{16}$ But by 2006 , this depiction had already begun to change, with Butler noting the exponential increase in conservative NGOs applying for UN accreditation. ${ }^{17}$ Chapter three, on globalization, confirms this development, showing that 'pro-family' groups increasingly see the global realm as ripe with opportunity for 'pro-family' activism, both in the UN arena and beyond it. 'Profamily' groups now see their message as one to which the people of the world are highly receptive. Given the successes the groups have had in broadcasting their principles, we can see that unlike their domestic base, 'pro-family' organisations are beginning to see the global realm as a space of opportunity, rather than opposition.

Yet these differences should not be overstated. 'Pro-family' stances on sexual politics are largely homogeneous throughout the domestic and the international Christian Right. As Butler and Buss and Herman note, opposition to homosexuality and abortion unifies Christian Right organisations more than any other set of issues. However, in forging a cross-religious, UN-affiliated, secular-sounding form of political activism, adherence to the 'pro-family' movement may involve muting or sidelining other relatively 'mainstream' Christian Right political activities, as were described in the introduction. ${ }^{18}$ The motivations driving the global activities of 'profamily' organisations need to be considered separately from those of the Christian Right as a whole. Acting globally is having an effect on the ideology and agenda of the 'pro-family' movement.

\footnotetext{
${ }^{16}$ Buss and Herman, op. cit., p. xxxii.

${ }^{17}$ Butler, op. cit., p. 113.

${ }^{18}$ As has already been noted, supporters of the 'pro-family' movement may be ignorant of what goes on at the international level. In an interview with Marsden, Crouse confides that the public supporters of Concerned Women for America are likely unaware of the alliances they are forming with governments which are 'not admirable': 'I'm not sure our constituency, and people in general, are aware at that level that we are working as closely as we are with people who are undesirable in so many other ways.' Marsden, L. (2008) For God's Sake: The Christian Right and US Foreign Policy (London and New York: Zed Books), p. 140.
} 
Part II: Understanding the emergence of 'pro-family' groups

There are a number of different ways to frame the entry of 'pro-family' organisations into the global political scene. In the remainder of this chapter I separate these different ways of thinking about 'pro-family' globalization into seven categories, which represent seven different causes as highlighted by authorities in this field.

The first observation, made by a number of different scholars, is that 'pro-family' activities beyond the US can be understood simply as a politics of opposition expanded to the global level. This has been expressed in a variety of ways. Some suggest that the international Christian Right sees opposition to concealed and corrupt enemies in the global realm as an important justification for the expansion of 'pro-family' politics. Another possibility is that opposition to domestic enemies is the key reason for the Christian Right's international activity. Lastly, most observers of these organisations acknowledge the importance of international progress on 'new' rights as a central aspect of the expansion of 'pro-family' protest beyond the domestic sphere.

Another framework offered by observers of the Christian Right is that global expansion has always been a part of the movement's agenda. Proponents of this view suggest that for 'pro-family' organisations, God's plan was never limited to the US. Linked to this framework is the importance of second coming beliefs in motivating global 'pro-family' activities. Leading Christian Right scholars warn observers of the 'pro-family' movement not to underestimate the importance of millennialism in the ideologies of these organisations. Because 'pro-family' activists see themselves as a religious force, the Bible and certain religious principles are recognised as motivating this activism. The role of scripture and religious identity are discussed in terms of their likely impact on the way these actors define their role in the global sphere.

Connected to the expansion of a 'pro-family' politics of opposition, scholars have noted the importance that 'pro-family' organisations attach to their efforts to 'correct the liberal bias' at the UN. Appealing to democratic principles, 'pro-family' 
activists portray themselves as resisting an 'international assault on the family,' conducted by powerful liberal organisations whose arguments go un-opposed in international institutions. In this way, perceptions of social upheaval are attributed to globalization, and create an impetus for conservative organising at both the local and the global levels. ${ }^{19}$

Another reason for the global emergence of 'pro-family' organisations is to do with their close associations with neo-conservatives. From the neo-conservative perspective, 'pro-family' activism provides a social framework - the 'aggressive promotion of American style values ${ }^{20}$ - which will help to bring about a democratic and capitalist 'new American century.' Finally, two prominent scholars on the Christian Right suggest that the expansion of 'pro-family' politics beyond the US is part of a broader effort to 'mainstream' the Christian Right movement. Connected to both mainstreaming and empire-building is the propagation of "profamily' research, intended to support the positions of 'pro-family' advocates from a non-religious perspective. Each of these eight frameworks is discussed in detail.

\section{A 'friend-foe way of thinking' globalized}

Internationally active 'pro-family' organisations clearly share a similar set of ideological perspectives with their domestic Christian Right base. These perspectives can perhaps be more accurately characterised in terms of what they oppose. In this light, 'pro-family' global activity can be understood as the globalization of a particular politics of resistance. This section discusses the different ways that scholars have used this politics of opposition to understand the global intentions of 'pro-family' organisations.

William Martin remarks that the same Christian Right agenda that motivates these organisations domestically - suspicion of secular organisations, hostility to 'antifamily' policies, and determination to maintain their way of life against the perceived threat of cultural annihilation - have driven Christian Right groups to

\footnotetext{
${ }^{19}$ For more on this see Butler, op. cit., pp. 125-131.

${ }^{20}$ Ibid, p. 136.
} 
become politically active at the global level..$^{21}$ This perspective seems reasonable, given that the organisations' entry into the UN has been through opposition to the same 'anti-family' policies they oppose at home. 'Pro-family' organisations saw their opponent's progressive ideas ascending in the global political realm, and thus threatening the domestic sphere from outside. In this framework, then, the organisations have begun to act globally to protect the 'pro-family' way of life from the intrusion of progressive opponents, and they remain globally active in order to continue this battle.

Buss and Herman describe this combative aspect of the 'pro-family' movement as a 'friend-foe' way of thinking, typical of organisations of the Christian Right. For these organisations, say Buss and Herman, 'a politics of change is constituted through a process of contesting "the enemy.", 22 Using this framework, determining who 'pro-family' groups believe their 'enemies' are can be a guide to understanding their motivations. The way that characterisations of enemy entities change is an indicator of the direction of the 'pro-family' movement. ${ }^{23}$

What Buss and Herman describe as a 'friend-foe' culture is similar to the anticommunist sentiment described by Sara Diamond in Roads to Dominion. 'Anticommunism,' Diamond writes, 'was, and is, a package of beliefs about the moral superiority of the United States... a dichotomous and reactive way of seeing the world. ${ }^{24}$ If 'pro-family' organisations do see entities in the global realm as either good or evil, then this 'friend-foe' belief system is likely to be a contributor to their mobilising beyond the US: they are called to combat 'evil' and protect 'good' on a global scale.

This way of thinking about 'pro-family' groups is simplistic, to say the least. It is bound to miss some of the other important aspects of the 'pro-family' movement and the way it is changing. Yet it is indisputably pervasive in 'pro-family'

\footnotetext{
${ }^{21}$ Martin, W. (1999) The Christian Right and American Foreign Policy, Foreign Policy, no. 114 (Spring 1999), p. 67. See also Armstrong, K. (2000) The Battle for God: Fundamentalism in Judaism, Christianity and Islam, (New York: Knopf).

${ }^{22}$ Buss and Herman, op. cit., p. 35.

${ }^{23}$ I discuss this in more detail in the following chapter.

${ }^{24}$ Diamond, S. (1995) Roads to Dominion: Right Wing Movements and Political Power in the United States (New York: The Guilford Press), pp. 8-9.
} 
discourse. In the discourse of these organisations, enemies are everywhere, and vigilance is vital. The sense of being threatened is a nearly universal feature of 'profamily' texts, and is almost certainly intended as a stimulus for action. To be fair, 'pro-family' groups are by no means alone in this; environmental and anti-nuclear organisations also exist - and at times, thrive - because of the sense of looming danger that they broadcast (and their adherents perceive). The difference between the world views of these NGOs and the Christian Right is about the way they moralise the dangers they discern. To use Steve Bruce's words: 'Bad things happen because bad people desire them,' in the Christian Right understanding of the world. $^{25}$

Although this thesis documents a number of examples in which 'pro-family' scholars seek to move away from this reactive form of politicking, 'friend-foe' politics persist as a strong element of 'pro-family' discourse. Because this particular framework is so useful in understanding 'pro-family' politics, I organise much of the research in this thesis around the way that 'anti-family' enemies and ideas are framed, in order to document the changing politics of these organisations. In the paragraphs that follow, I briefly discuss three of the ways that observers of the Christian Right have used a form of this 'friend-foe' framework to explain the global emergence of 'pro-family' organisations.

One of these frameworks is described as combating an 'enemy other.' Peter Beyer's influential 1994 book Religion and Globalization held that the Christian Right would struggle to find firm footing in the global sphere because they require an identifiable outside enemy: a primary operating principle of this group, in Beyer's view. Some theorists (Huntington being the most obvious) expected to see Islam arise as the 'enemy other' in the worldview of the Christian Right. ${ }^{26}$ But this has not been the case.

\footnotetext{
${ }^{25}$ Bruce, S. (2008) Fundamentalism ( $2^{\text {nd }}$ ed.) (Cambridge: Polity Press), p. 114.

${ }^{26}$ In the final pages of Globalizing Family Values Buss and Herman correctly point out that while Islam may be a sort of eternal rival, and perhaps a problem for the missionary sector of the Christian Right, conservative Islamic groups and governments are more likely to be seen as allies of 'profamily' organisations. For a thorough description of the tensions between the US 'pro-family' movement and its conservative Muslim allies, see Butler (2006), op. cit.
} 
If the Christian Right needs outside enemies, and global space does not allow for an 'outside,' how, then, have 'pro-family' organisations managed to globalize so successfully? In her 2001 article Siren Song, and again with Buss in Globalizing Family Values, Herman provides a useful way of understanding how the Christian Right has been able to thrive under conditions of globalization. She argues that globalization has created a number of different international foes for these organisations. ${ }^{27}$ According to Herman, these new foes are more difficult to recognize and combat successfully because they are not identified with one nation, ethnicity or religion. But they are still at large in the world, and have become all the more threatening through their anonymity. In this way, 'pro-family' organisations have gained a foothold in the realm of international development politics by focussing their fear on unidentifiable enemies. This lack of specificity, in Herman's view, has in fact facilitated network-building at the global level. This is because the concealed nature of these enemies necessitates a global retaliation in order for the forces of good to win the day. Herman (who has the advantage of hindsight over Beyer) is very likely correct in this observation. This raises a question that is addressed in chapters three to six of this thesis. Is a vague, unseen 'enemy other' enough to sustain 'pro-family' interest in the global realm over time, or will it give way to more visible or specific enemies?

Another theory to explain the 'pro-family' emergence in international politics is that these organisations have globalized in order to more successfully oppose particular enemies at home. In Esther Kaplan's view, the international activities of 'profamily' organisations are primarily a means of achieving domestic goals rather than global ones. Kaplan, who devotes a chapter to the global activities of the Christian Right in her unapologetic tirade against the Bush White House, suggests that the main reason for 'going global' was to find ways to bankrupt organisations hated by the domestic Christian Right, such as Planned Parenthood. ${ }^{28}$ This understanding of the motivations of 'pro-family' organisations is a variation on Keck and Sikkink's

\footnotetext{
${ }^{27}$ See Herman, D. (2001) 'Globalism's Siren Song: the United Nations and International Law in Christian Right Thought and Prophecy,' the Sociological Review, vol. 49, no. 1. p. 72, and Buss and Herman, op. cit., p. 141.

${ }^{28}$ Kaplan, E. (2004) With God on their Side: How Christian Fundamentalists Trampled Science, Policy and Democracy in George W. Bush's White House (New York: The New Press) pp. 228-9.
} 
'boomerang pattern,' in which domestic NGOs seek allies beyond their nation-state to bring about the domestic policy changes they desire. ${ }^{29}$

Though Keck and Sikkink's 'boomerang effect' is an excellent way of explaining the motivations of some transnational political actors, it is not useful here. Keck and Sikkink's theory does not fit the 'pro-family' experience. The boomerang effect requires domestic actors to seek an international or global authority to bring pressure to bear on their own government. In the 1990s, when 'pro-family' organisations worked in the context of a US administration that they uniformly loathed, they still saw global space as hostile to their way of life. ${ }^{30}$ If this perception has changed, it has done so only after the election of President Bush. For this reason, the boomerang effect can only be a valuable framework for understanding the motivations of 'pro-family' groups in the post-Bush context.

In addition, seeing the international realm in terms of its uses to the domestic constituency also belies the degree to which 'pro-family' organisations now see their role as international policy makers and part of a global 'pro-family' movement as an end in itself. Though there is evidence that particular progressive organisations remain a focus of 'pro-family' wrath, ${ }^{31}$ the nemeses of 'pro-family' organisations are themselves global actors. Thus this narrow purpose, if it were ever the main objective of 'pro-family' activism, is no longer as important as the broader agenda pressed for by advocates of the 'natural family.' 'Pro-family' politics has its own rationale and global ambitions, a fact largely ignored by the domestic focus of Kaplan's analysis and the boomerang effect.

Perhaps most importantly, a number of scholars suggest that opposition to 'new' human rights, particularly the right to abortion, is the main reason that 'pro-family' organisations have become globally active. Anti-abortion sentiment was undoubtedly central to the attendance of 'pro-family' organisations at the UN conferences of the 1990s. In interviews with Swinski, 'pro-family' leaders said that

\footnotetext{
${ }^{29}$ Keck and Sikkink, op. cit., p. 12.

${ }^{30}$ Buss and Herman write in 2003 that 'pro-family' organisations view global space as controlled by a number of 'anti-Christian forces, all working in concert to undermine the "natural family" and, even more fundamentally, religious belief itself.' Buss and Herman, op. cit., p. xxxii.

${ }^{31}$ I discuss the ways in which these organisations emerge in 'pro-family' discourse in chapters three and five.
} 
they and their organisations got involved in the UN to prevent liberal governments and NGOs active in that arena 'from instituting an international right to abortion, first threatened at the Cairo conference. ${ }^{32}$

This perspective is also present in Buss and Herman's analysis, who suggest that these 'new rights,' of women and children are seen by the Christian Right as a Trojan horse, masking a "more nefarious "anti-family" agenda. ${ }^{33}$ Thus for Buss and Herman, part of the reason that 'pro-family' organisations are motivated to act at the UN is because they felt they were called to combat 'anti-family' foes who had seized (or were close to seizing) control of the UN. From this perspective, 'new' human rights, such as sexual and reproductive rights, were (and are) a means of concealing the true ambitions of those who would use the UN for their own (malevolent) purposes. I discuss the way this kind of thinking appears in 'profamily' discourse in chapters three, four and five.

Outside of the 'friend-foe' line of analysis, there are a number of different ideas offered by observers of 'pro-family' organisations as to the reasons they have emerged on the global scene. The motivations (as offered by literature on the Christian Right) that have encouraged the 'pro-family' movement to become, and remain, active at the global level are discussed in detail in the remainder of this chapter.

\section{Global expansion was always a part of the Christian Right agenda}

While it may be the case that international activity has been an important step in winning specific battles for 'pro-family' organisations, it is possible that this has always been an aspect of Christian Right ideology. This argument can be made in a number of different ways. Some authors emphasise the scriptural importance of globalization in the fulfilment of end times scenarios derived from the Book of Revelation. Others consider missionary activity, opposition to communism, and interest in the Middle East as evidence that the Christian Right has always had its eye on the world beyond the US.

\footnotetext{
${ }^{32}$ Interviews with Austin Ruse, Wendy Wright, Allan Carlson and Thomas Jacobson, in Swinski, op. cit., p. 216.

${ }^{33}$ Buss and Herman, op. cit., p. 46.
} 
Feminist academic Linda Kintz takes this latter view. Though she does not address the globalization of 'pro-family' politics, she sees the extension of religious conservatism beyond the nation-state as part of a system built on an 'American mythology' which is intimately connected to a religious adherence to free markets. This mythology can be depicted as

'...a closed set of concentric circles stacked one on top of the other and ascending heavenward: God, property, womb, family, church, free market, nation, global mission, God. ${ }^{34}$

Using Kintz's framework, the ideology of 'pro-family' organisations' has never been confined to the US. In this sense, the world beyond the US is, and always has been, a part of the Christian Right agenda. Applying Kintz's idea to the globalization of the 'pro-family' movement suggests that the organisations see their role as part of a 'global mission,' extending conservative Christianity and capitalism throughout the world. ${ }^{35}$

Though plausible, this framework is not particularly helpful. While it is likely true that the Christian Right has always been mindful of what has been going on outside the US, it says nothing about why 'pro-family' leaders felt they had to act beyond the US at the time they did so and in the way they have. Most importantly, it does not highlight the importance of sexual and reproductive politics as an impetus to 'pro-family' activism.

\section{Second Coming beliefs are integral to 'pro-family' activism}

One of the major questions in the literature on internationally active 'pro-family' organisations is to what degree millennialism (also referred to as end times and second coming beliefs) is driving the emergence and perseverance of the international 'pro-family' movement. Many influential books and articles on 'profamily' organisations do not discuss scripture or prophecy in their analyses of these

\footnotetext{
${ }^{34}$ Kintz, L. (1997) Between Jesus and the Market: The Emotions that Matter in Right-Wing America (Durham: Duke University Press), p. 6.

${ }^{35}$ See also Brouwer, Gifford and Rose (1996) Exporting the American Gospel: Global Christian Fundamentalism (Routledge: New York and London).
} 
organisations and their motivations. ${ }^{36}$ This section discusses the extent to which prophetic literature and ideas about the second coming provide a useful means of understanding the motivations of 'pro-family' organisations in the global realm.

Buss and Herman clearly see second coming beliefs as a major component of the way that the Christian Right understands 'the global.' Analysis of 'CR UN' perceptions of global space in Buss and Herman's book are peppered with insights as to the connections between global entities and end times beliefs in Christian Right prophetic literature. For example, the UN, as Buss and Herman observe, has played an important role in second coming scenarios as a 'One World Government' run by a charismatic Antichrist, seen as a precursor to Tribulation. ${ }^{37}$ Similarly, Buss and Herman write that end times scenarios, in which 'true' Christians are bestowed with the ability to resist the deceptions of the Antichrist, are connected to a 'fear of conspiracy,' or as Herman has written elsewhere, a 'paranoid style' that is deeply embedded in US culture. ${ }^{38}$ In this way, Buss and Herman suggest that premillennialism (the belief that Christ's second coming will bring about a thousand years of His rule on Earth) shapes the way that believers see the social and political world and their role in it.

Martin's understanding is similar, suggesting that Christian Right actors hold 'a conviction that increasing globalization is a fulfilment of dire Biblical prophecies foreshadowing the return of Christ and the onset of Armageddon. ${ }^{, 39}$ In his article, Martin sees the internationalisation of the Christian Right as arising from two wells: a desire to broadcast their conservative ideological agenda globally, and a motivation to 'win the world for Christ.' While they may be both be present and motivating Christian Right political activity, these two ideas are fundamentally different, and lead to quite different forms of international activity. While the literature appears to unanimously accept the first motivation, that there is a conservative (or 'traditional') social agenda driving the organisations, it is far less clear about the role of Christian Right sacred texts and popular literature.

\footnotetext{
${ }^{36}$ Marsden and Swinski have nothing to say on this topic. Though Butler describes the way that apocalyptic fiction has been used to support the US neoconservative political agenda, she does not use themes from this literature to explain the global activism of 'pro-family' organisations.

${ }^{37}$ Buss and Herman, op. cit., p. 12.

${ }^{38}$ Ibid, pp. 12-13. See also Herman, op. cit., p. 66.

${ }^{39}$ Martin, op. cit., p. 67.
} 
In Siren Song, Didi Herman emphasises the central place of Armageddon and the Second Coming in the Christian Right conception of 'the global.' Without such a framework, she argues, academic attempts to understand the Christian Right at both the domestic and the international level are incomplete. As evidence for her claim, Herman offers three main arguments. The first is that for decades the Christian Right has identified the 'cultural degeneration' of the late twentieth century as an apocalyptic precursor to end times, and so its members already believe that the end is near. ${ }^{40}$ The second argument Herman makes is that the political policy-makers of the Christian Right elite are among the millions of Americans who purchase prophetic literature and believe ardently that Jesus will return. ${ }^{41}$ Stuart Croft and Kevin Phillips both offer additional support for this argument, quoting polls which find that around two thirds of conservative Protestants surveyed said they believe that the events described in the Revelation to John will come true. ${ }^{42}$

Herman's third reason to take end times beliefs seriously is that many Christian Right foreign policy positions only make sense against the backdrop of an apocalyptic attitude. Her main example is the eagerness with which the historically anti-Semitic Christian Right supports Israel, described in the introduction to this thesis. Herman explains backing for Israel through its place in the prophetic mindset: rapture-minded Christian Right activists want the US government to defend Israel and the Jews, in the hope that America will be spared during the 'final days. ${ }^{43}$ Croft puts it this way:

'If the 'end times' thesis is accepted - as it is widely in the red states of America then there is a particular role for Israel to play, and the role of [conservative Protestants] is to support Israel in its coming battles. ${ }^{44}$

\footnotetext{
${ }^{40}$ As an explanation of what the Christian Right sees as 'cultural degeneration' Herman suggests 'secularization, sexual immorality, worship of the state, crime and drugs, for example.' Herman, op. cit., p. 65.

${ }^{41}$ Herman writes that '...many millions of Americans, including political policy-makers (see Barkun, 1987: 168; Boyer, 1992: 141-4) read The Revelation for signs, buy prophetic literature, and believe fervently in the scenarios.' Herman, op. cit., p. 66.

${ }^{42}$ Croft, S. (2007) 'Thy Will Be Done: The New Foreign Policy of America's Christian Right,' International Politics, vol. 44, no. 6, p. 693. See also Phillips, K. (2006) American Theocracy: The Peril and Politics of Radical Religion, Oil and Borrowed Money in the $21^{\text {st }}$ Century, (London: Penguin Books), p. 102.

${ }^{43}$ Herman, op. cit., p. 66.

${ }^{44}$ Croft, op. cit., p. 705.
} 
Like Herman, Croft sees the protection of Israel as based on 'theological predispositions. ${ }^{45}$ There is no hint in Croft's article that end times scenarios or theology in general are used as rhetorical tools by political actors. Likewise, Herman rejects the idea that conservative actors use end times scenarios and language to conceal their true motives, arguing that second coming beliefs 'must be understood as providing a belief-framework that shapes, influences, and impacts upon political activity. ${ }^{46}$ She concludes her argument in Siren Song by affirming that 'any analysis of [Christian Right] global ideology that neglects premillennialism does so at great cost. ${ }^{, 47}$

Croft suggests that end times beliefs and prophetic literature are the foundations for Christian Right foreign policy positions in general. He notes that theological understandings of world events are accepted ways of thinking within the parameters of Christian Right discourse in the US. ${ }^{48}$ He cites an example from the Robertson School of Government teaching programme at Regent University, Gov 654: International Politics, which promises to teach 'a God-centred understanding of international affairs,' in order that students can 'apply Biblical principles to an analysis of peoples, nations and international organisations; to help discern the footprints of the coming of Christ's new world-wide order. ${ }^{49}$ Phillips, for his part, notes that 55 per cent of white evangelical Protestants agreed that 'following religious principles' should be a top priority for foreign policy in a 2004 Pew Research Center poll. ${ }^{50}$

Croft accepts without debate that Christian Right interpretations of biblical principles feed into their foreign policy positions. Buss and Herman, however, take a more cautious approach. Although they acknowledge that there are many other

\footnotetext{
${ }^{45}$ Ibid, p. 706.

${ }^{46}$ Herman, op. cit., p. 66.

${ }^{47}$ Ibid, p. 66. Millennialism is the belief that in the future, there will be a time of paradise on Earth during which Christ reigns, prior to the end of the world.

${ }^{48}$ Croft, op. cit., pp. 697-699. Croft makes the observation that there has been little scholarly analysis of the role played by religious faith in US foreign policy. He suggests that this is partly because the Christian Right's view of the world is shaped within a separate subculture: academics struggle to know how to analyse the material they find.

${ }^{49} \mathrm{See}$ http://www.regent.edu/acad/schgov/academics/courses.htm [last accessed 16/10/08], or alternatively Croft, op . cit., p. 698. Of the over 50 courses described on this web-page, however, it may be of interest to discover that the word 'God' appears only in the excerpted text.

${ }^{50}$ Phillips, op. cit., p. 365.
} 
motivating factors, they repeat that the Christian Right's international activism 'cannot be fully understood without acknowledging the role played by theological belief systems. ${ }^{51}$ Buss and Herman stress that they are not saying that the only way that Christian Right activism can be understood is through theology; rather that their emphasis on the theological underpinnings of Christian Right behaviour is a response to the scarcity of literature on the topic. ${ }^{52}$

Finally, in terms of their understanding of international governing institutions, Buss and Herman suggest that the Christian Right do call on their millennial ideas (not just their conservative ones) when they are considering globalization. They suggest that for the Christian Right, 'one-worldism without Christ at the helm is an illusion and an impossibility. ${ }^{53}$ The authors offer a number of Christian Right texts which do in fact endorse world government (of a conservative Christian variety), which include some images of global theocracy that moderate conservatives would find distasteful. ${ }^{54}$ Other than this, Buss and Herman refer the reader back to arguments made in Siren Song to justify their contention that end times beliefs persist as a motivating factor for Christian Right international activism.

While Herman's and Croft's article, and Buss and Herman's book provide many detailed, important and intelligent contributions to the literature, second coming beliefs as a motivator for global activism are unlikely to be as important as these authors suggest. Moreover, a focus on these beliefs has the potential to obscure or mystify more important ideological factors that are driving the politics of the "profamily' movement. Though I do not make this claim for the Christian Right as a whole, I suggest that for understanding globally active 'pro-family' groups (especially when considering the discourse of elites), looking for representations of end times scenarios in 'pro-family' texts is unlikely to uncover the driving forces behind global 'pro-family' activism. Nevertheless, since this thesis is an attempt to

\footnotetext{
${ }^{51}$ Buss and Herman, op. cit., p. xxxiii.

${ }^{52}$ Ibid, p. 8-9.

${ }^{53}$ Ibid, p. 30.

${ }^{54}$ Buss and Herman offer a couple of examples: 'Jesus Christ will be the King over all the earth [sic] in His theocratic world government' from Billy Graham's 1992 “Storm Warnings,' or the following from Christopher Corbett: 'ultimately globalism will triumph - but not the false globalism of the Antichrist and today's spirit of antichrist... But the Kingdom of Christ will truly triumph. All nations will bow before His throne as He rules from His capital in Jerusalem. That is a true globalism which every Christian will enjoy.' Quoted in ibid, p. 30.
} 
understand the ideology and motivations of Christian Right 'pro-family' groups at the global level, and Buss and Herman still arguably represent the conventional wisdom on this question, each of their arguments need to be addressed. The following section discusses the reasons for and against the consideration of second coming beliefs as a factor in the global emergence of 'pro-family' groups

Herman's first argument for taking second coming beliefs seriously, made in Siren Song, is that the liberalisation of social mores have for decades indicated to the Christian Right that the end is nigh. 'Pro-family' activists' investment in reversing this liberalisation suggests that the groups subscribe more to post- than premillennialism. This is a Christian view of the future which holds that Christ will arrive after the millennium, and - crucially - after Christians have established a Christian Kingdom on Earth. In Globalizing Family Values, Buss and Herman suggest that pre-millennialist principles may be decreasing in significance in Christian Right thought, in favour of post-millennialism. This is of practical importance, they note, because 'theologically, postmillennialism makes more sense of religious activism' and allows for a deeper unity of purpose with conservative Catholic organisations. As they put it, postmillennialism 'entails building a Christian world in the here and now. ${ }^{55}$ This development, which I would argue is a movement away from conscious millennial thought altogether, makes 'pro-family' organisations more like NGOs than pre-millennial Christians. Like other international NGOs, they are trying to change the world to make it more as they would like it to be. This is not to say that their motivations are not 'millennial,' it is more that 'pro-family' groups are heavily involved in bringing about the social change they believe God wills, rather than leaving God to do it.

To Herman's second point, that millions of Americans read prophetic literature and believe in the scenarios is undeniable. However, sociologist Michael Lindsay argues that many elites in the Christian Right disassociate themselves from the popular literature associated with second coming scenarios. In his interviews with evangelicals, Lindsay was surprised to find a significant number of evangelical leaders who spontaneously volunteered that they had never read the Left Behind

\footnotetext{
${ }^{55}$ Ibid, p. 16.
} 
series. ${ }^{56}$ He suggests that these 'cosmopolitan' evangelicals want the Christian Right movement to be taken seriously beyond their own networks, or in Lindsay's words, they are 'trying to distinguish themselves from the rest of the evangelical subculture. ${ }^{57}$ It seems likely that 'pro-family' activists at the global level do fall into this category, preferring the respect of their conservative peers - and indeed those of other religions - over that of Christian Right popular culture. I return to this issue later in this chapter. Even if they have read prophetic literature, given the context of their political activity, 'pro-family' activists are less likely to express their millennial beliefs overtly. Thus if end times beliefs are motivating the elites of the 'pro-family' movement, they are working beneath the surface, so to speak.

Thirdly, in terms of explaining Christian Right foreign policy positions, there may be factors other than end times beliefs at play here. It is irrefutable that there is a section of the Christian Right specifically dedicated to increasing and maintaining US evangelical support for Israel. ${ }^{58}$ In addition, it seems likely that Israel - being the birthplace of Jesus - will always be a sacred site for many Christians, in addition to its potential role in the second coming. Thus theology must be given due credit for explaining this particular Christian Right foreign policy position. There are other reasons for Christian Right support for Israel, however. One is the enduring alliance between the Christian Right and neo-conservatives, ${ }^{59}$ whose interest in Israel has more to do with its geo-strategic influence than its role in end times scenarios. Israel's proximity to Muslim countries may also be part of the reason for the domestic Christian Right's continued interest in 'protecting' that country. While 'pro-family' organisations have had some success in forging new alliances with Islamic groups, Islam remains a perpetual adversary and rival proselytizer in the eyes of many in the domestic Christian Right movement. Finally, entrenched policies can be extremely difficult to shift when they are backed by

\footnotetext{
${ }^{56}$ This best-selling fictional series by Tim LaHaye is the most famous of Christian Right prophetic literature. For the full interview, see Lindsay, M. (2008) 'American Evangelicalism: New Leaders, New Faces, New Issues,' Faith Angle Conference on Religion and Public Life, May 2008. Available at the Pew Forum for Religion and Public Life, http://pewresearch.org/pubs/883/americanevangelicalism [last accessed 30/6/08].

${ }^{57}$ Ibid.

${ }^{58}$ See pp. $12-13$ of this thesis, and Croft, p. 705.

${ }^{59}$ See Butler, op. cit., p. 135, also see http://www.newamericancentury.org/ in general.
} 
effective lobby groups, even when they impose significant political costs on the governments who promote them. ${ }^{60}$

The penchant for searching out conspiracies, which Buss and Herman see as connected to the apocalyptic narrative, is certainly present in 'pro-family' discourse. However, the degree to which conspirational thought is attributable to Christian Right apocalyptic beliefs is disputable. The tendency towards conspiracies can be traced to roots outside the context of end times beliefs, such as in the anticommunist accusations of the John Birch Society and in the beliefs of members of the US Militia Movement. ${ }^{61}$

Lastly, to Herman's statement that she does not believe conservatives are using the language of Armageddon as a cover for other political motives, this is undoubtedly true. It should be noted however, that the internationally active 'pro-family' groups under scrutiny in this thesis seldom use this language at all. For example, in her analysis of literature from 'A.D. 2000 and Beyond' (a clearinghouse established just before the year 2000 which encourages extensive international evangelism), Sara Diamond finds no suggestion that the end of the world is imminent. ${ }^{62}$ Similarly, a search for terms related to Armageddon on the websites of the groups under scrutiny in this thesis found no relevant references. ${ }^{63}$

There are, I would argue, a few stylised allusions to second coming beliefs, which could be connected with millennialism. One example is Allan Carlson's suggestion that the 'natural family' is the path to 'a world restored.' 64 The 2008 'pro-family' film, Demographic Winter: the Decline of the Human Family (which is examined in

\footnotetext{
${ }^{60}$ See Mearsheimer, J. and S. Walt (2007) The Israel Lobby and US Foreign Policy (New York: Farrar, Strauss and Giroux).

${ }^{61}$ See Diamond, S. (1995) Roads to Dominion: Right Wing Movements and Political Power in the United States (New York: The Guilford Press), pp. 53-57 for a history of the John Birch Society. ${ }^{62}$ Diamond (1998) Not By Politics Alone: the Enduring Influence of the Christian Right (New York: the Guilford Press), p. 203.

${ }^{63}$ Searches for the terms Armageddon, second coming, rapture, apocalypse/ptic and antichrist resulted in no hits on C-Fam's website. On the websites of CWA and the Howard Center these terms were found, but only in quotations from individuals not associated with the organisation, or in one case, 'apocalypse' is used as a metaphorical device unconnected to the second coming.

${ }^{64}$ Carlson, A. (2005) 'Beyond the Culture War: On the Natural Family: A Manifesto,' Concerned Citizens for America town hall meeting, 20 October 2005, Central Christian Church, Rockford, Illinois, available at http://www.profam.org/docs/acc/thc.acc.cca.051020.htm [last accessed 07/09/09].
} 
detail in chapter six) also has an undeniably apocalyptic 'feel,' as does its 2009 sequel, Demographic Bomb. Nevertheless, the content is still resoundingly issuebased and leaves the restoration of the world to humanity rather than the return of Jesus. The existence of a linguistic/cultural disposition in the US (and elsewhere) that tends to see the end of history as predetermined and near may be debated. But if it exists, it is not peculiar to the Christian Right. ${ }^{65}$ Thus, insofar as scholars can say anything about people's motivations, the distinct absence of millennial language used by 'pro-family' groups that employing it as a framework for analysis of their motivations is questionable.

Given this absence, then, why do Buss and Herman see it as so important that prophetic literature is acknowledged in the globalization of 'family values?' In their discussion of the 'natural family,' which was discussed earlier in this chapter, Buss and Herman write that

'[Christian Right] family theology is... both a restatement of what conservative Christians believe God intends and a new common sense; that neither God nor Jesus contributed to this doctrine is neither here nor there. ${ }^{66}$

In their view, as noted earlier, given the lack of biblical authority for the "natural family, ${ }^{67}$ its importance to 'pro-family' activism can be understood as having arisen as a counter-discourse to feminism and gay rights activism. In setting aside the lack of scriptural justifications for the 'natural family' as interesting but unimportant, Buss and Herman acknowledge that the rise of the 'natural family' movement is best understood in primarily for social and political - that is, counterdiscursive - rather than scriptural or prophetic terms. Yet given the dearth of any 'pro-family counter-discourse' on millennialism, Buss and Herman's emphasis on its significance in the globalization of the Christian Right must be questioned.

Buss and Herman would argue, presumably, that just because 'pro-family' organisations do not openly discuss end times scenarios does not mean that they

\footnotetext{
${ }^{65}$ The word 'Armageddon' has been used by Wall Street commentators to describe the 2008 global credit crisis, for example.

${ }^{66}$ Buss and Herman, op. cit., p. 4.

${ }^{67}$ Buss and Herman write that 'the idea of the natural family as the basic cornerstone of society is not something easily identified in biblical texts. .. the New Testament is in fact anti-family; it constructs the Jesus movement as an alternative community that leaves biological family behind.' For their excellent and concise analysis on this topic, see Buss and Herman, op. cit., pp. 2- 4.
} 
have no impact on the ideologies of these groups. But the absence of such end times scenarios in itself marks a significant shift in the discourse. It is likely that "profamily' elites see talking about the second coming as a guaranteed route to marginalisation. Astute political Christians know that talking about rapture does not inspire the respect of a secular or interfaith audience; fear of being labelled a religious fanatic would certainly limit the openness with which they share their views on this topic. Thus while I cannot, and do not, make the claim that end times beliefs are not underlying 'pro-family' activism in the global arena, the absence of open discussions of the second coming and apocalyptic language in the texts of 'pro-family' groups is in itself highly politically relevant, as it is indicative of 'profamily' audiences and agendas. Either 'pro-family' organisations do not see their global activities as particularly connected to the return of Christ, or they do not want others to believe this is the case. At any rate, I would argue that over time, the distinction between these alternatives may become less relevant. Nevertheless, to the extent that they can be understood to be present in the discourse of 'pro-family' organisations, end times scenarios are identified and discussed.

\section{The Bible as a motivator behind 'pro-family' activism}

The Bible clearly has an impact on the motivations of 'pro-family' organisations. By definition 'pro-family' groups are self-selected and self-organised into issues which they, as Christians, deem to be important. Many evangelical Protestants claim as the basis of their faith that the Bible is the inerrant and literal word of God. Even so, psychologists Ronald Hopson and Donald Smith offer some compelling arguments that suggest that looking for religious motivations in Christian Right behaviour is not a particularly useful thing to do. Hopson and Smith identify a drift away from religiosity within the Christian Right movement. ${ }^{68}$ Retreating from an 'explicitly religious emphasis,' they suggest, is only a problem for the Christian Right if their religious identity is the only thing of importance to the movement as a whole. They note, however:

'That some Christian Right groups willingly masks [sic] the religious dimension of their agenda... argues for an expanded consideration of the bases for Christian Right

\footnotetext{
${ }^{68}$ Hopson, R. E. and D. R. Smith (1999) 'Changing Fortunes: An Analysis of Christian Right Ascendance within American Political Discourse,' Journal for the Scientific Study of Religion, vol. 38 , no. 1 , p. 4.
} 
political ideology. As religious tenets are selectively employed to sacralize a priori political convictions, to emphasize solely the religious dimension is purely arbitrary. ${ }^{, 69}$

Moreover, the authors suggest that the associations the Christian Right makes with 'unholy' groups (they use the Unification and Catholic Churches as examples, but in our international context, we can take this argument further by noting the alliances 'pro-family' activists are making with conservative Islamic groups and governments) are evidence of the non-religious foundations of Christian Right activism. ${ }^{70}$ Such alliances show that 'pro-family' activism may involve suppressing certain theological motivations - such as the calling to evangelise non-Christians in order to pursue more politically astute conservative ones.

Hopson and Smith go so far as to suggest that the religious substantiation the Christian Right makes for its political positions are superimposed onto what they term 'pre-existing ideological commitments.' ${ }^{71}$ Hence, they argue, the trend towards secularization of Christian Right discourse and behaviour, rather than being taken as a sign of the movement's demise, may help to uncover the real foundations of Christian Right socio-political values. ${ }^{72}$ If the Christian Right's political positions do not emerge as the result of a literal reading of the Bible, the authors conclude, it is imprudent to assume that Christian Right ideology is a rendering of Biblical mores applied to the political realm. ${ }^{73}$

However, the argument can be made that the motivations for political activism are still Christian, even in the absence of Biblical justifications, if the proponents of those political actions believe they are carrying out the will of God. But given that this means that the way that God makes His will known to 'pro-family' activists is via culture rather than scripture, this in a way lends further weight to the arguments of Hopson and Smith: that 'pro-family' identity is socially or culturally constructed, and based on a rendering of the Bible that is peculiar to a set of Christian conservatives, who subscribe to a particular ideological worldview. From this

\footnotetext{
${ }^{69}$ Ibid.

${ }^{70}$ Ibid.

${ }^{71}$ Ibid.

72 Ibid.

${ }^{73}$ Ibid.
} 
perspective, the task of this thesis is to discern what the 'pro-family' worldview is, and how it is changing, rather than attempting to pin down whether and which biblical narratives have influenced their activism. In this thesis, then, whilst I acknowledge that the Bible is an important aspect of 'pro-family' culture and identity, I do not refer to scripture as a means of uncovering the driving forces of 'pro-family' global activism.

\section{Correcting the liberal bias at the UN}

US Christian Right organisations have frequently depicted the UN and other international institutions as liberal, secular and eager to encroach on US sovereignty. In this light, 'pro-family' organisations have characterised their entry in to the UN system as correcting a liberal bias in international politics. Moreover, 'pro-family' organisations see their global efforts as vital to amending a false belief of conservatives from the developing world: that they are an isolated few, fighting against a powerful onslaught of massive liberal organisations. Part of the goal of the 'pro-family' network is to create a bloc of 'pro-family' states at the UN, in order to put a stop to the invasion of national sovereignty in countries dependent on UN development funding.

Seeing religion as absent from debates around development, Butler suggests that international actors among the Christian Right have characterised themselves as the de facto voice for religion and tradition. ${ }^{74}$ Butler, concerned that the entry of the Christian Right on the UN stage may appear to be more democratic than it is, suggests that the UN NGO arena is characterised by a problem familiar to observers from the US: the polarisation of civil society into the religious right and the secular left. ${ }^{75}$ This can be read as a global extension of the culture wars: the kind of global

\footnotetext{
${ }^{74}$ Butler, op. cit., p. 85.

${ }^{75}$ This is likely to be unavoidable, however. Pearson and Tomalin note that '... the version of religious authority - political or spiritual - which is represented at international meetings and negotiations invariably reflects those elements which hold political power in any given faith community.' Pearson, R. and E. Tomalin (2008) 'Intelligent Design? A Gender-Sensitive Interrogation of Religion and Development,' in Gerard Clarke and Michael Jennings (eds.) Development, Civil Society and Faith Based Organisations: Bridging the Sacred and the Secular (London and New York: PalgraveMacMillan), p. 47.
} 
clash that Philip Jenkins foretells, between the religious South and the secular North. $^{76}$

Swinski is also dubious about the Christian Right's claim that its presence enhances the democratisation of the UN civil society process. Her thesis finds that some of the key elements of the democratic process are noticeably absent in the behaviour of international anti-abortion organisations. These groups, she suggests, tend not to share the same core liberal philosophy of their progressive opponents, so 'they do not seek consensus, work inclusively, or work for the greater legitimacy of the UN. ${ }^{77}$ If Swinski's thesis is correct, then 'pro-family' reasons for entering the UN arena are more likely to be about fighting their opponents and winning the day. From this point of view, 'having the conservative perspective heard' is merely a rhetorical tool used by 'pro-family' organisations to justify their entry to others. In this sense, this appeal to democratic representation does not help us to understand the motivations of 'pro-family' organisations at the UN, other than that they seek to be included.

Nevertheless, crying foul over a 'liberal bias' does say something about the way 'pro-family' organisations depict the international community and the opportunity they see to 'do good' there. This assertion suggests a view of the world in which conservative people from the South need 'pro-family' help in order to network effectively. In other words, 'pro-family' organisations see their task as showing conservatives in the South that there are still a mass of conservative religious people in the world whose voices, if heard, can prevent the kind of liberal progress that 'pro-family' groups seek to halt. They seek to say that - contrary to what 'profamily' groups see as a popular delusion across the globe - there has not been a massive global decline in people who care about 'traditional' values. This characterisation of the political world, in which the 'silent majority' begins to fight back against a vociferous but powerful minority, is discussed in more detail in chapter five.

\footnotetext{
${ }^{76}$ Butler, op. cit., p. 85-87. See also Jenkins, P. (2007) The Next Christendom: The Coming of Global Christianity, (Oxford: Oxford University Press).

${ }^{77}$ Swinski, op. cit., p. 322.
} 


\section{6. 'Pro-family' emergence may be a result of globalization}

In reviewing the activities of a globally active 'pro-family' organisation from Mexico, Butler suggests that 'pro-family' globalization may be a result of political and economic forces having a destructive effect on conservative 'family values' everywhere. She traces the origins of Red Familia, a Mexican 'pro-family' organisation, from its participation in the WCF in 1999 to 2006, showing the organisation's increasing influence beyond the domestic Mexican political scene. Similarities between the origin of 'Red Familia' and that of US 'pro-family' groups suggest to Butler that

'the Christian Right [of other countries] might continue to globalize not only because of US initiatives, but because global economic and social trends are creating the same conditions in many countries that the Christian Right first addressed in the US. $^{78}$

Butler thus sees globalization as a force that may be actually encouraging the expansion of 'pro-family' groups beyond their national boundaries. This observation is an important one because, to a large extent, it suggests that the globalization of US 'pro-family' groups has more to do with globalization than it has to do with the ideology of 'pro-family' organisations.

Different 'pro-family' organisations may all be globalizing in support of 'the family' but they may not share the same ideas about what the 'family' needs to be protected from. Though there is evidence that some 'family' issues peculiar to the South are addressed in 'pro-family' discourse - such as the absence of fathers due to labour migration and the effect of armed conflict on families - there is still a significant degree to which the 'mutual transformation of participants' in the global 'pro-family' network is yet to occur. Some US 'pro-family' organisations have tended to insist on including opposition to homosexuality in their international documents, despite the fact that this issue is not a major concern for conservatives in the South. ${ }^{79}$ Despite some dissonance in the priorities of different 'pro-family' groups, networking and interaction are proving to be sources of change for globally active US 'pro-family' organisations. The ways in which 'pro-family' organisations from the US claim to reflect the different needs of their partners in the South, as

\footnotetext{
${ }_{78}^{78}$ Butler, op. cit., p. 126.

${ }^{79}$ See ibid, pp. $74-5$ for more on this.
} 
part of a global movement 'in support of the natural family,' is discussed in chapters five and six. Insofar as 'pro-family' emergence is a result of globalization, the ideologies of all 'pro-family' groups, whether from the US or outside it, have an impact on the direction of the movement. As Butler puts it, 'many NGOs emerge radically changed by their encounter with globalization and global organising, even as they seek to change the world. ${ }^{80}$

\section{The neo-conservative/'pro-family' alliance}

Butler observes that though the 'pro-family' alliance with US neo-conservatives has its issues, there is good reason to consider the impact of neo-conservatives in stimulating 'pro-family' global activism. She writes that

'While Christian Right leaders were initially driven to the UN by concerns that the international body was making decisions that would impact American law, neoconservative intellectuals invite religious conservatives to view their movement for conservative family values not as a defensive move, but nothing less than as an integral component of a process of American empire-building that will help America save and democratise the world. ${ }^{81}$

She suggests that neo-conservatives have been interested for some time in the 'global-local links of the culture war. ${ }^{82}$ 'Pro-family' organisations, says Butler, have received considerable support from neo-conservative organisations and thinktanks as part of a 'tightly knit' conservative network which shares 'staff, fellows, board members and funding sources. ${ }^{83}$ In this sense, it is likely that 'pro-family' organisations cannot help but be affected by the views and successes of their neoconservative allies. The production of 'pro-family' social science, for example, has a precedent in the successful neo-conservative think-tanks such as the American Enterprise Institute and the Heritage Foundation. Many of these groups are also active at the UN. Butler's reminder to take this historical alliance into account may both uncover underlying neo-conservative influences on 'pro-family' ideology and highlight new tensions arising as the agenda of 'pro-family' organisations changes to reflect the new demands of their global environment.

\footnotetext{
${ }^{80}$ Ibid, p. 152.

${ }^{81}$ Ibid, p. 135.

${ }^{82}$ Ibid, p. 137.

${ }^{83}$ Ibid, p. 141.
} 


\section{Mainstreaming 'pro-family' politics}

In discussing what the domestic Christian Right gains from the globalization of 'pro-family' organisations, Buss and Herman write that 'this expanded political engagement ... suggests a movement that is seeking a more mainstream political profile. ${ }^{, 84}$ This desire is evident, say the authors, in the 'pro-family' production of ever more sophisticated 'expert discourse on the natural family. ${ }^{85}$ To this, I would add that there has been a rapid increase in cross-country comparative studies on family and social policy, which facilitates (and is facilitated by) the growing international 'pro-family' network of 'experts' on the 'natural family.'

In this effort to normalise (or de-marginalise) their concerns, Buss and Herman suggest that 'pro-family' organisations have been relatively successful. 'Natural family' research, say Buss and Herman, has had a significant impact and is seldom associated with the conservative Christian politics of its authors. ${ }^{86}$ This finding leads Buss and Herman to consider the degree to which this means the Christian Right is using 'stealth tactics' to advance an uncompromised religious agenda, or whether it indicates the merge of Christian Right ideology into mainstream politics.

There is more to this mainstreaming success than the 'stealthy' use of statistics to influence government policies, however. In terms of the agenda of global 'profamily' organisations, I suggest that the more important question raised by this effort is how the 'pro-family' movement will manage the increasingly disparate ideological demands of its political alliances. Political activity at the global level entails an open and ongoing declaration of 'pro-family' values. Deciding what this platform will be is arguably the most important role played by the WCF. In this context, the degree to which the organisations are 'assimilationist' or 'stealthy,' to use Buss and Herman's words, is only relevant if it affects their ability to convince their audience of their goals. 'Pro-family' organisations, if they are to win allies and show their opponents that they are a legitimate political force, will gain the respect of international elites by displaying their (changing) agenda in tones and language

\footnotetext{
${ }^{84}$ Buss and Herman, op. cit., p. 140.

${ }^{85}$ Ibid, p. 140.

${ }^{86}$ Ibid, p. 140.
} 
appropriate to their audience. The ways in which this is occurring are discussed in chapters three to six.

\section{Conclusion}

There is no single reason why the 'pro-family' movement has gone global. All the explanations described above have some relevance. Nor are they mutually exclusive. Some motivations may be operating on some 'pro-family' actors at some points in time, and not at other times.

Some of the ideological forces described above may have evolved from others. For example, 'mainstreaming' the movement may be an attempt to move away from a 'friend-foe' way of thinking. What may have started out as an effort to bankrupt Planned Parenthood may have evolved into a global 'pro-family' mission to save the families of the world from the liberal UN. Opposition to 'new' human rights may have been a lesson to 'pro-family' activists in how to articulate their own agenda in the language of human rights, which may have had an unintended but expedient 'mainstreaming' effect. The connections and tensions between these different motivations are explored in the chapters that follow.

This thesis explores the different ways that these driving forces - and a number of others discovered during my research - are acting upon different sections of the 'pro-family' movement, as well as whether they are changing over time. The methods I incorporate to carry out this task are discussed in the following chapter. 


\section{Chapter Two: Methodology}

'All that is necessary for the triumph of evil is that good men do nothing. Get EAlerts! Take Action!'

Concerned Women for America homepage, $2008^{1}$

In this chapter, I describe and justify my selection of 'pro-family' organisations and explain how I use the texts from these organisations. The chapter consists of two parts. In the first, I show why I have chosen this particular set of 'pro-family' groups to represent the 'pro-family' movement as a whole, and address the potential problems with this selection. I then offer a brief description of each group that details how they satisfy the criteria I have laid out.

In the second part of the chapter, I discuss why I have approached the subject from a political science framework and why I use discourse analysis as a means of understanding the driving forces behind their global activism.

\section{Part I: Selection of 'pro-family' groups}

Five organisations were chosen as representative of the US 'pro-family' movement. I sought a number that was representative of the movement and inclusive of many of its elements, but that was also able to be studied in adequate depth. I used four selection criteria: presence at one or more World Congress of Families (WCF) events, other evidence of global or international focus, diversity of views between the groups, and evidence of political influence. What follows is an explanation of each criterion, followed by a discussion of the issues raised by this selection process.

\section{Selection Criteria}

The organisations I examine in this thesis were chosen from a list of 'pro-family' groups, foundations and sponsors involved in the WCF. ${ }^{2}$ The WCF is an international meeting of 'pro-family' organisations. It has been held five times, in

\footnotetext{
${ }^{1}$ Concerned Women for America's homepage, available at http://www.cwfa.org/main.asp [last accessed 24/08/09].

${ }^{2}$ See http://www.worldcongress.org/ for a list of organisations involved in this event [last accessed 25/02/09].
} 
Geneva, Prague, Mexico City, Warsaw and Amsterdam. This event facilitates the flow of ideas between 'pro-family' activists and coordinates the (US-led) 'profamily' international agenda to a large degree. The WCF is an example of what Keck and Sikkink call a 'voluntary, reciprocal and horizontal pattern of communication and exchange. ${ }^{3}$ This form of exchange is common between $\mathrm{NGOs}^{4}$ and provides evidence that these organisations are attempting to coordinate a movement beyond the US. In other words, organisations involved in exchanging their ideas in such a setting can be considered global broadcasters - and receivers of 'pro-family' ideas.

In addition to their involvement in the WCF, a second requirement of the organisations was that they be globally active in some other respect. This was either through attending UN conferences with UN Economic and Social Council (ECOSOC) NGO accreditation, or in the form of chapters or affiliations with partner organisations from other countries. This stipulation was required because attendance at a conference alone was an insufficient criterion for the groups to be considered politically active.

Thirdly, the selection needed to be sufficiently diverse in order that it would represent the different set of values in the 'pro-family' movement. Although similarity between organisations in a social movement is to be expected, variation between the groups was a requirement for inclusion. Because it is not feasible to exhaustively study every 'pro-family' organisation, each group under scrutiny represents a collection of priorities and conflicts that are sufficiently dissimilar to the others that range is maximised and repetition is minimised. For example, Phyllis Schlafly's Eagle Forum is excluded in this study, as I do not consider the agenda and constituency of this group to be significantly different from Concerned Women for America (CWA) to warrant its inclusion (CWA was preferred as it is the more internationally active group).

\footnotetext{
${ }^{3}$ Keck, M. and K. Sikkink (2006) 'Transnational Advocacy Networks in International Politics,' in Perspectives on World Politics $\left(3^{\text {rd }}\right.$ edn.) ed. by Richard Little and Michael Smith (New York: Routledge), p. 171.

${ }^{4}$ In this thesis, I consider 'pro-family' groups as a particular set of NGOs. See section two of this chapter for more on this.
} 
Finally, while diversity is useful in that it increases the potential breadth of research on 'pro-family' organisations, it was important to exclude anomalous groups that have no influence on the movement. For this reason, a final requirement of this selection process was some evidence that the groups chosen exerted some influence on 'pro-family' discourse. I included three sub-criteria for inclusion, which were: a track record indicating the organisation's knowledge of, and presence at, 'profamily' causes; submission of a tax return, showing at least a minimal level of public donations; and interest or antagonism from political rivals, such as progressive NGOs or academics.

\section{Limits and potential issues with the selection process}

With the first requirement of involvement in the WCF, there is what Buss and Herman call an 'elite/street' issue: organisations that are present at the WCF are an 'elite cadre' of individuals who are not representative of the core 'pro-family' movement as a whole. ${ }^{5}$ This is very likely to be the case. However, I suggest that a focus on elites is desirable, as they have been responsible for the organisations' emergence in global politics. ${ }^{6}$ The WCF is a forum in which 'pro-family' leaders gather in order to discuss the movement's global direction: though they may be constrained by their supporters to some degree, they nevertheless push the movement in the direction they want it to go. As this thesis seeks to uncover the changing ideologies of 'pro-family' organisations in the international realm, a focus on the elites of the movement is inevitable and, I would argue, appropriate. I return to this issue in the second half of this chapter.

In explaining the intended role of the WCF, Allan Carlson (its coordinator) states that the WCF is not an ecumenical effort at joining the world's religions, rather it is 'a coalition of the most orthodox believers within each denomination, church or faith group, persons who are the least likely to compromise their core beliefs. ${ }^{7}$ The

\footnotetext{
${ }^{5}$ Buss, D. and D. Herman (2003) Globalizing Family Values: The Christian Right in International Politics (Minneapolis: University of Minnesota Press), p. xviii.

${ }^{6}$ As one observer of the Christian Right writes, elites 'shape the symbols which define the public discourse' of the Christian Right. Detwiler, F. (1999) Standing on the Premises of God: the Christian Right's Fight to Redefine America's Public Schools (New York: NYU Press), p. 134.

${ }^{7}$ Carlson, A. (2005) 'On the World Congress of Families,' Presentation to the Charismatic Leaders Fellowship Jacksonville, Florida January 12, 2005. The Howard Center, available at http://www.profam.org/docs/acc/thc.acc.020112.wcf.htm [last accessed 24/08/09].
} 
WCF is a venue, says Carlson, in which its participants can 'respond together to the global spread of a militant secularism that threatens the liberties and existence of all vital faiths. ${ }^{, 8}$ Assuring his audience that the WCF is "NOT a massive organisation with visions of power and permanence,' Carlson states that 'it will continue only so long as it proves helpful to others and to the defense of the family."

Unlike other scholars of the international Christian Right, I have considered activities beyond the UN as a requirement for a 'pro-family' organisation's inclusion in this research. Because this thesis considers globalization, or the global broadcasting of 'pro-family' ideologies, it is important to look beyond the UN: the $\mathrm{UN}$ is one aspect of the global landscape for these groups, not all of it. Here I am suggesting that 'pro-family' involvement in the UN should not be examined separately from the globalization of 'pro-family' organisations in general. Given the rapid rise of conservative forms of Christianity in the South, it seems likely that North-South partnerships between conservative Christian organisations outside of the UN will become more significant. In other words, the groups' involvement at the UN - facilitated by the Bush administration - may in time be understood as incidental to their globalization. For this reason, groups which are active beyond the UN are included in my analysis. Finally, including non-UN affiliated groups or activities may confirm that the UN has a moderating influence on 'pro-family' NGOs; as it conveys legitimacy, it also constrains behaviour.

In terms of the diversity requirement, excluding highly similar groups may emphasise groups that are marginal to the movement over more influential 'mainstream' 'pro-family' organisations. An additional problem is that it is highly likely that NGOs are created simply for the purpose of acquiring coveted UN ECOSOC accreditation, which as Elizabeth Arweck puts it, is 'an undisputed cachet of legitimisation. ${ }^{10}$ This effort bolsters the presence of 'pro-family' organisations at the UN, but says more about the organisational aptitude of some actors in the movement than it says about the makeup and diversity of 'pro-family' organisations

\footnotetext{
${ }^{8}$ Ibid.

${ }^{9}$ Ibid (emphasis in original).

${ }^{10}$ Arweck, E. (2007) 'Globalization and New Religious Movements,' in Religion, Globalization and Culture: International Studies in Religion and Society, ed. by Peter Beyer and Lori Beaman (Boston: Leiden), p. 265.
} 
as a whole. This is part of the reason that participation at the WCF is included as a criterion. Firstly, attendance at an overseas conference is costly, ${ }^{11}$ and secondly, the conference organisers are eager to present the conference as an international event, rather than as a speaking forum for North American NGOs with identical agendas.

A further concern here is how to judge whether a 'pro-family' organisation is globally active in a political sense. It could be argued that an organisation's very presence on the world wide web renders them a global entity by definition. That anyone in the world with internet access can access a church's webpage means that such messages potentially have a global audience, but it does not mean that these churches seek a global influence. Thus for the purposes of this thesis, if the organisation's intent is to influence the views of individuals or organisations beyond its membership, its internet activities can be considered political. If this activism is directed towards increasing the organisation's global influence, then I consider the organisation to be globally politically active. Thus the NGOs under scrutiny here satisfy one final criterion: they are going beyond US borders in order to change (or save) the whole world from 'anti-family' forces or trends. ${ }^{12}$

It should be noted that I have not included any Mormon institutions in my selection. Though I acknowledge the contribution Mormon groups have made in the globalization of the 'pro-family' movement, it was necessary to keep the number of organisations small and manageable. In addition to this, there are Mormons on the board of one of the groups I examine. ${ }^{13}$ These board members are closely associated with prominent Mormon 'pro-family' activists and scholars. ${ }^{14}$ Mormon 'pro-family' groups continue to make a significant contribution to this movement, and it is assumed that this research will incorporate some of the 'pro-family' perspectives strongly held by Mormon organisations.

\footnotetext{
${ }^{11}$ The WCF has always been held outside the US (although the preparatory meetings have tended to be held within the US).

${ }^{12}$ It may be that the organisations are only pursuing this course because they see it as the best way to promote the interests of the US, but this still means their agenda is both global and political.

${ }^{13}$ See 'Statement 6' of the Howard Center's 2006 IRS form 990 (Return of organisation exempt from Income Tax Form).

${ }^{14}$ See Butler, J. (2006) Born Again: The Christian Right Globalized (England: Pluto Press), p. 105.
} 
What follows is a description of the groups that I have chosen as representative of 'pro-family' discourse. Spin-off groups and 'think tanks' are discussed alongside the organisations that founded them, except in the case of HLI and C-Fam, which have diverged so significantly that they warrant independent inspection. The five groups under scrutiny were created with different intended audiences and arenas of action, and have evolved differently over time. Superficial differences in tactics and language are of interest because they suggest important ways in which 'pro-family' groups are adapting to global political terrains by using different approaches. For each of the five groups, I describe the organisation's origins and structure, their international emergence, their mission statements, their level of funding and the major points of difference between the organisations. ${ }^{15}$

\section{Concerned Women for America/the Beverly LaHaye Institute}

Concerned Women for America (CWA), founded by Beverly LaHaye in 1979, is the 'women's wing' of the internationally active Christian Right. CWA's origins have been retold many times. As the story goes, LaHaye and her husband were watching a television interview with Betty Friedan in 1979, when the prominent feminist declared that she was speaking on behalf of American women. LaHaye, incensed by this assertion, reacted by calling a meeting of Christian Women to discover whether or not this was actually the case. ${ }^{16}$ Encouraged by the attendance of well over a thousand women, LaHaye created CWA with the purpose of opposing the 'anti-God, anti-family rhetoric' of feminists. ${ }^{17}$ Since its inception, the organisation has grown in numbers and in influence, and in 2008 boasted half a million members with almost 500 chapters spread across all 50 states. ${ }^{18}$

\footnotetext{
${ }^{15}$ Funds are in US dollars.

${ }^{16}$ See www.cwfa.org/history.asp [last accessed 15/06/08].

${ }^{17}$ Ibid. Susan Faludi notes, however, that by the late 1970s, LaHaye's name and prominence in the evangelical community was already guaranteed to draw a crowd. See Faludi, S. (1991) Backlash: The Undeclared War Against American Women (London: Chatto \& Windus), p. 280.

${ }^{18}$ See http://states.cwfa.org/states/, and 'Today' at http://www.cwfa.org/history.asp [last accessed 15/06/08]. Though CWA undoubtedly has an influence that exceeds their membership, it is likely that membership numbers are misleading. Michael Standaert notes that CWA membership is 'indefinite for anyone who has ever paid the annual membership fee.' He continues: 'Former National Organisation for Women president Eleanor Smeal declared that if her organisation used the same system, their membership would be "in the millions." Standaert, M. (2006) Skipping towards Armageddon: The politics and propaganda of the Left Behind novels and the LaHaye empire (Brooklyn: Soft Skull Press), p. 117.
} 
CWA works as two organisations for tax purposes, one to which charitable donations are tax deductible, and one that is legally allowed to engage in partisan lobbying. CWA is a predominantly Protestant organisation, although a significant number of conservative Catholic women are members. ${ }^{19}$ CWA's mission is

'to protect and promote Biblical values among all citizens - first through prayer, then education, and finally by influencing our society - thereby reversing the decline in moral values in our nation. ${ }^{20}$

CWA publishes Family Voice, a bi-monthly magazine, available both in print and via its webpage. It also broadcasts other items under the titles 'Press Releases,' 'Op/Eds,' and 'In the News.'

Along with LaHaye, CWA's president Wendy Wright frequently appears on television and other media. The major source of international commentary and activism is Dr. Janice Shaw Crouse, a former speechwriter for President George W. Bush. $^{21}$ In 1999, CWA launched a think-tank, the Beverly LaHaye Institute (BLI), which claims to recognise 'the power of good data and analysis to inform and substantiate policy positions. ${ }^{22}$

Prior to the 1990s, CWA's international advocacy was chiefly directed towards opposing communism, with LaHaye publicly endorsing Reagan's support for the Nicaraguan Contras. ${ }^{23}$ Although anti-communism persists as a theme in the language CWA uses, after the Cold War, observers note a shift in the organisation's focus away from communism and towards preventing feminist progress at the UN.

\footnotetext{
${ }^{19}$ Buss and Herman, op. cit., p. Xxviii.

${ }^{20}$ CWA's 'vision statement,' which is slightly different, adds that CWA's hope is for 'women and like-minded men, from all walks of life, to come together and restore the family to its traditional purpose and thereby allow each member of the family to realize their God-given potential and be more responsible citizens.' See 'About CWA,' at www.cwfa.org/about.asp [last accessed 11/06/08].

${ }^{21}$ See 'Who's Who in CWA,' at http://www.cwfa.org/articledisplay.asp?id=2112\&department=CWA\&categoryid [last accessed 11/08/09].

${ }^{22}$ See http://www.cwfa.org/articledisplay.asp?id=2112\&department=CWA\&categoryid [last accessed 18/06/08].

${ }^{23}$ Marsden, L. (2008) For God's Sake: the Christian Right and US foreign policy (London: Zed Books), p. 28.
} 
In the 1990s, responding to the success of the women's health and rights movement in that arena, CWA sought, and was granted, official ECOSOC status. ${ }^{24}$

With annual public donations on the rise, and now totalling over $\$ 10$ million, ${ }^{25}$ CWA's website states that the organisation

'...is blessed with members and friends who contribute generously. We don't, however, receive funds from large corporations, liberal foundations, or left-wing billionaires. Our average gift is less than $\$ 30$, but because we have power in numbers, we are able to be one of the most effective organizations representing your views anywhere.' 26

CWA's foot soldiers - or 'kitchen table activists' as they are referred to by the organisation - make the organisation a powerful political force in the US, through their letter writing campaigns and their ability to respond quickly to proposed legislation. ${ }^{27}$ However, 'kitchen table activists' have little to do with CWA's global activities. As already noted, CWA's work at the UN is entirely financed by one anonymous donor. ${ }^{28}$ Moreover, Crouse acknowledges that CWA's supporters are probably largely unaware of the organisation's international activities. ${ }^{29}$ This lack of awareness is likely to serve the organisation well, as there is some conflict between CWA's inherent nationalism and historical opposition to 'handouts,' and its relatively new role in international development politics. This role requires connecting with the interests of people in poor countries, which is an essential part of legitimising CWA's presence at the UN. More than the other groups examined here, CWA remains resolutely 'pro-America,' treating interaction with the outside world with a caution which sometimes appears to be approaching contempt. Thus CWA must balance a moderately pro-development position to its global audience, even as the organisation maintains a general anti-welfare, anti-UN and fairly isolationist stance at home. This conflict is shared by other Protestant Right groups

\footnotetext{
${ }^{24}$ See http://www.un.org/esa/coordination/ngo/ for all NGOs with consultative status at the UN Department of Economic and Social Affairs [last accessed 11/06/08].

${ }^{25}$ See Concerned Women for America's IRS form 990s from 2004 to 2008.

26 'Stand With Us to Protect the American Family,' Concerned Women for America, available at http://www.cwfa.org/support_cwa.asp [last accessed 11/06/08].

${ }^{27}$ For more information on the success of CWA's 'grassroots' strategies, see Gardiner, S. (2006)

'Concerned Women for America: A Case Study,' Coalition for Human Dignity, at Www.feminism.eserver.org/cw-of-a.txt [last accessed 06/06/08].

${ }^{28}$ Marsden, op. cit., p. 140.

${ }^{29}$ Ibid, p. 140.
} 
active at the UN, and this thesis relies on CWA texts (among others) to demonstrate this particular tension within the US 'pro-family' movement.

These are not the only conflicts at work within CWA. CWA's activities at the UN have involved developing alliances which the Christian Right as a whole would consider to be beyond the pale. Marsden observes that at the same time as the Bush administration was publicly denouncing the 'Axis of Evil,' CWA was working alongside Libya, Iraq, Iran and Sudan against the international recognition of women's rights. ${ }^{30}$ At an ideological level, CWA declines the opportunity to take a firm position on a number of 'pro-family' issues. Unwilling to condemn the use of contraception within marriage, or the right or desire of women to pursue a career, ${ }^{31}$ CWA represents an important set of conflicts faced by conservative women as they struggle with feminism.

Despite these issues, CWA remains a big gun in the international 'pro-family' movement. As Standaert suggests, CWA's influence has translated into real changes in international policy. ${ }^{32}$ The organisation has significant influence within the Republican Party: it is estimated that over a million listeners tune in to CWA's daily radio show, whilst hundreds of thousands of subscribers and church members receive publications from this organisation on a regular basis. ${ }^{33}$

\section{Human Life International}

Human Life International (HLI) is an extensive Catholic anti-abortion network which was founded in 1972. 'With 99 satellite offices in 80 countries,' HLI's website advertises itself as 'the largest international, pro-life, pro-family, prowoman organisation in the world. ${ }^{34}$ Led by Thomas J. Euteneuer, HLI does not have UN ECOSOC accreditation. HLI does not seek official permission or endorsement to run their campaigns. The organisation erects anti-condom billboards, lobbies political figures and proselytises wherever possible. HLI offers the following statement about its motivations:

\footnotetext{
${ }^{30}$ Ibid, p. 140.

${ }^{31}$ LaHaye, Crouse and others at CWA are themselves working mothers, as has been pointed out by a number of feminist opponents of CWA.

${ }^{32}$ Standaert, op. cit., p. 128.

${ }^{33}$ Marsden, op. cit, pp. 47-8.

${ }^{34}$ See http://www.hli.org/hli_maps_affiliates.html [last accessed 23/02/09].
} 
'The babies are the reason why. Everything HLI does is dedicated to saving lives and strengthening families throughout the world. Because we are the only pro-life presence in many countries - and because the culture of death is active on so many fronts - HLI's global approach to the life issues is indispensable. ${ }^{35}$

HLI appeals solely to conservative Catholics in its fundraising efforts. Utilising its steadily growing budget - now just under $\$ 4$ million $^{36}$ - Euteneuer and his colleagues travel to far-flung destinations to spread HLI's message. Unlike many 'pro-family' organisations, HLI funds are used for more than research and advocacy. In its international activism, HLI runs 'crisis pregnancy' centres, teaches courses on 'natural family planning' to young married couples, trains recruits all over the world to be domestic lobbyists and 'pro-life' counsellors, and hosts local 'pro-life' radio and television programmes in countries all around the world.

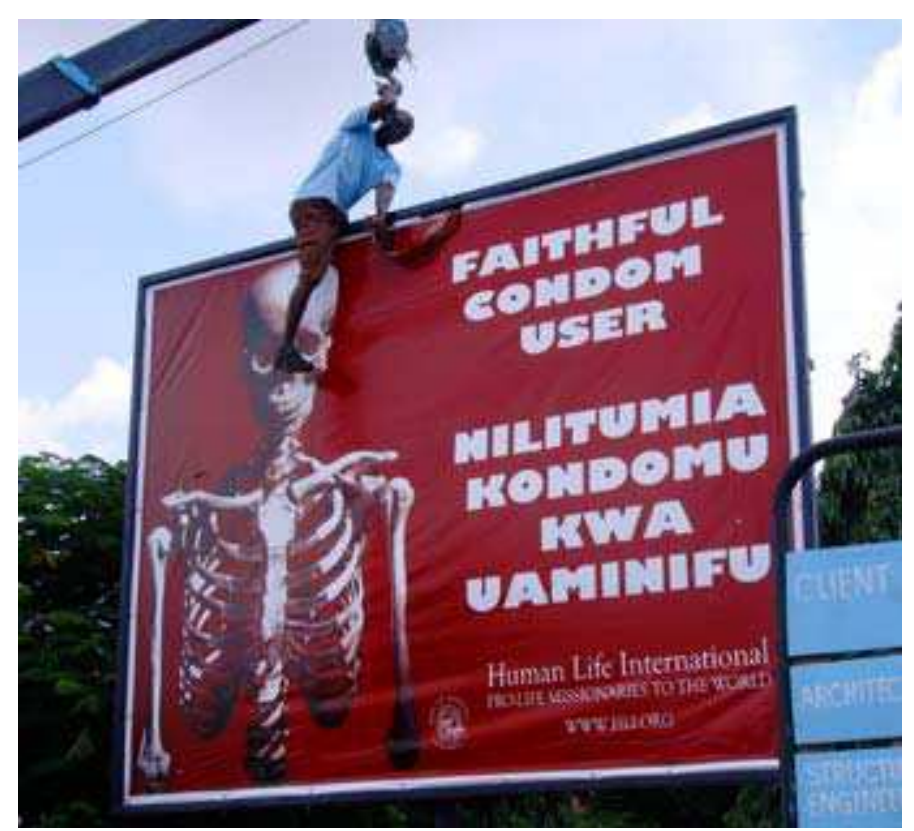

HLI Billboard, Tanzania, $2008^{37}$

HLI publishes Special Report, a monthly journal that discusses the progress (or otherwise) of the international 'pro-life' movement and offers highlights from Euteneuer and his colleagues 'pro-life missionary trips.' HLI also publishes Spirit

\footnotetext{
${ }^{35}$ See 'Our Mission' at http://www.hli.org/mission.html [last accessed 23/02/09], (Emphasis in original).

${ }^{36}$ HLI's public donations have risen from just over \$2 million dollars in 2003 to just under \$4 million in 2006. See HLI's 2003, 2004, 2005 and 2006 Calendar Year IRS Form 990, Return of Organisation Exempt from Income Tax Forms.

${ }^{37}$ Human Life International (2008) Human Life International Front Lines, Spring 2008. http://www.hli.org/front_lines_spring_2008.pdf [last accessed 17/10/06].
} 
and Life, a monthly e-newsletter, and Front Lines, a quarterly magazine which sends 'news from the missions' to HLI supporters' email inboxes, and a number of books and other publications. HLI's 'pro-life' missionaries distribute books such as The Case Against Condoms and The Art of Natural Family Planning: Student Guide. ${ }^{38}$

\section{The Catholic Family and Human Rights Institute}

Though it is an offshoot of HLI, the Catholic Family and Human Rights Institute (C-Fam) is a different type of organisation altogether. For some time, C-Fam publicly maintained that it was not affiliated with HLI, though it no longer does so. ${ }^{39}$ After HLI's application for official NGO status at the UN was turned down, CFam functioned as a point of access to UN meetings for the excluded Catholic organisation. ${ }^{40}$ Created in 1997 , C-Fam is a sophisticated advocacy organisation with strong connections within the 'pro-family' movement. C-Fam has guided a number of other conservative NGOs through the process of gaining UN ECOSOC accreditation, and is the most well-known of the 'pro-family' organisations at the UN. ${ }^{41}$ Lead by seasoned activist and journalist Austin Ruse, C-Fam's primary purpose is to

'...educate the delegates at the UN and the general public on family issues and human rights. It does this through the publishing of newsletters, papers, and other informational lectures. ${ }^{42}$

C-Fam's mission also includes 'educating the public at large about the pressing issues debated at the UN and at other international institutions, ${ }^{43}$ particularly those that deal with sexual, reproductive or religious issues. Since it was established, this has been achieved through the distribution of the Friday Fax, a weekly roundup of

\footnotetext{
${ }^{38}$ See http://www.hli.org/publications.html [last accessed 18/06/08].

${ }^{39}$ For more on this, see Kissling, F. and J. O'Brien, 'Bad Faith at the UN: Drawing Back the Curtain on the Catholic Family and Human Rights Institute,' (Catholics for a Free Choice, 2001). Available at http://www.catholicsforchoice.org/topics/other/documents/2001badfaithattheun.pdf [last accessed 11/08/09].

${ }^{40}$ HLI was denied accreditation due to its 'aggressive language' and 'extremist anti-Semitic and anti-Muslim statements.' See Butler, op. cit., p. 95.

${ }^{41}$ Ibid.

42 'Statement 3 - Form 990, Part III - Organisation's Primary Exempt Purpose,' from the Catholic Family and Human Rights Institute 2006 Calendar Year IRS Form 990, Return of Organisation Exempt from Income Tax Form.

${ }^{43}$ Ibid.
} 
events at the UN written for a socially conservative - but not necessarily religious audience.

C-Fam has a think-tank called the International Organisations Research Group (IORG). IORG is dedicated to

'advancing a deeper understanding of social policies advanced at the international level in order to protect and promote better national policies regarding human life, the family, religious freedom, and human rights. ${ }^{44}$

IORG's research is published in 'White Papers,' which are investigations of CFam's institutional foes, pursued as legal arguments and framed in reasoning and language that seldom refers to religion. C-Fam's annual funds averaged around $\$ 900,000$ from 2004 to 2007 , and the organisation has previously relied on financial support from other organisations, notably HLI Canada and Brigham Young University. $^{45}$

Including Catholic groups is vital to understanding the 'pro-family' worldview. In many ways, the Vatican was responsible for the entry of 'pro-family' groups into the UN system in the early 1990s when it called on people of faith to get involved in international policy-making on reproductive health. Catholic groups have a different understanding of the global sphere from their Protestant 'pro-family' allies. Seeing their religious identity as shared by millions of people around the world, Catholic organisations have seen the world beyond the US as a sphere of opportunity for far longer than their Protestant allies. Catholic organisations have a history of working within diverse communities in countries all over the world, and have shown themselves to be well equipped to accompany their 'pro-family' partners in global activism.

Though it is likely true that conservative Catholics and Protestants have lately found that they have more in common with each other than with liberal members of their own religion, ${ }^{46}$ there are still important differences that need to be managed in the relationship. The Pope is still occasionally depicted as the Antichrist in US

\footnotetext{
${ }^{44}$ See http://www.c-fam.org/publications/id.68/default.asp [last accessed 15/06/08].

${ }^{45}$ See C-Fam's IRS form 990s from 2004 to 2007 . Also see Kissling and O'Brien, op. cit.

${ }^{46}$ Butler, op. cit. p. 34.
} 
evangelical subculture, for example. ${ }^{47}$ In addition, the Vatican has taken a number of political positions that are at odds with the Protestant Right, most notably over the death penalty and the Iraq War. Protestant and Catholic groups which work together must modify their discourse to emphasise shared values and goals, whilst playing down historical, cultural and political tensions in this alliance.

\section{Focus on the Family/the Family Research Council}

In the 'pro-family' movement, Focus on the Family (Focus) is 'the big one. ${ }^{48}$ The organisation was established by evangelical Christian conservative James Dobson in 1977. Dobson, a psychologist, is arguably the most important activist in the 'profamily' movement: as Marsden puts it, Dobson is 'the man whose endorsement conservative Republicans most crave. ${ }^{49}$ Focus is run as a 'non-profit ministry,' offering advice and counselling on a variety of 'pro-family' issues. ${ }^{50}$ Dobson has never received a salary from his work at Focus, ${ }^{51}$ he has made his fortune through royalties from his books, which are usually in bookshelves in the 'self-help' section, and are bought overwhelmingly by women. ${ }^{52}$

Focus has a vision of 'redeemed families, communities and societies worldwide through Christ,' and its mission, as stated on its website, is

'To cooperate with the Holy Spirit in sharing the Gospel of Jesus Christ with as many people as possible by nurturing and defending the God-ordained institution of the family and promoting biblical truths worldwide. ${ }^{53}$

The organisation is based on six guiding principles, which it states are 'drawn from the wisdom of the Bible and the Judeo-Christian ethic, rather than from the humanistic notions of today's theorists.' 54 These are: 'the pre-eminence of evangelism; the permanence of marriage; the value of children; the sanctity of

\footnotetext{
${ }^{47}$ See, for example, 'Conclusive Proof from the Bible that the Pope is the Antichrist,' at http://www.pacinst.com/antichri.htm [last accessed 19/03/09], and 'Is Pope Benedict XVI the Antichrist?' at http://www.popebenedictantichrist.com/ [last accessed 19/03/09].

${ }^{48}$ Buss and Herman, op. cit., p. xxviii, Butler, op. cit., p. 111.

${ }^{49}$ Marsden, op. cit. p. 49.

${ }^{50}$ Johnson, E. (1998) 'Dr. Dobson's advice to Christian Women: the Story of Strategic Motherhood,' Social Text, no. 57, Winter 1998.

${ }^{51}$ Welsome, E. (2006) 'James and the Giant Jihad,' 5280 Magazine, August 2006, http://www.5280.com/issues/2006/0608/feature.php?pageID=502, [last accessed 19/06/08].

52 Johnson, op cit., p. 57.

${ }^{53}$ See http://www2.focusonthefamily.com/aboutus/A000000408.cfm [last accessed 19/03/09].

${ }^{54}$ See 'About Us,' at www.focusonthefamily.com [last accessed 25/01/09].
} 
social life; the importance of social responsibility; and the value of male and female. ${ }^{55}$ Focus' website defines sexuality as 'a glorious gift [from God] to be offered back to Him either in marriage for procreation, union, and mutual delight or in celibacy for undivided devotion to Christ. ${ }^{56}$ Dobson broadcasts his daily radio show to 164 countries, with an audience of over 220 million people in 15 languages. ${ }^{57}$

Focus is a latecomer to the international scene. Early disappointment with feminist successes at the international level, combined with the general evangelical suspicion of the UN, confirmed Focus activists' suspicions that the world outside the US was 'anti-family' and 'anti-God.' By 2001, however, C-Fam's Austin Ruse had convinced Dobson to apply for UN ECOSOC status, and the organisation swiftly established itself as a leading force in international 'pro-family' politics. Focus' clout is extensive: in Butler's words,

'Focus has ministries in twenty countries around the world, all of which are run by nationals who sign a licensing agreement to use the Focus on the Family label... Through affiliates Focus can indirectly influence the capitals of UN member states. $^{, 58}$

Thus it is clear that even without its UN NGO accreditation, Focus would be able to exert some influence on the UN, with its connections to 'pro-family' states.

Dobson set up the Family Research Council (FRC) in Washington DC in 1983. This was in order that he could be more directly politically active without compromising Focus' identity as a 'ministry,' or the tax exempt status of its burgeoning revenue. FRC is lead by Tony Perkins, a highly capable political activist with a particular interest in opposing same-sex marriages and civil unions. The organisation uses 'rapid action cells' to deploy members to oppose or support legislation deemed politically significant by its leadership. ${ }^{59}$ FRC receives annual donations of around $\$ 10$ million, whilst 'pro-family' behemoth Focus commands $\$ 125$ million in public

\footnotetext{
55 Ibid.

${ }^{56}$ Ibid, also see Marsden, op. cit., p. 139.

${ }^{57}$ See http://www2.focusonthefamily.com/aboutus/a000000993.cfm [last accessed 02/03/09].

${ }^{58}$ This was seen in the anti-cloning bill advanced by Costa Rica in 2003. For more on this issue, see Butler, op. cit., pp. 117-125.

${ }^{59}$ Marsden, op. cit., p. 37.
} 
support on a yearly basis. ${ }^{60}$ FRC publishes the Insight series, which as Buss and Herman note, 'function as valuable position papers for the [Christian Right] movement as a whole.' 61

Movement into the global realm has been complicated for both FRC and Focus. While both have been relatively successful, Focus' transformation into an international entity has involved careful management. In attempting to marry its 'helping' character with its role in political/cultural warfare, and export both globally, Focus broadcasts a kind of American family credo which appears to be warmly received in many parts of the world. But as many women in poor countries remain politically and socially marginalised (and well outside the context of a backlash against feminism) Dobson's message to women of romanticised 'Biblical submission' as a counter-cultural act ${ }^{62}$ requires some modification for audiences in the global South.

The same can be said for Focus and FRC's passionate opposition to homosexuality, which is a lightning rod domestically, but is far less politically relevant in the global South. ${ }^{63}$ Conservative organisations in the South may agree with 'pro-family' stances on sexuality and reproduction, but poverty remains a far more important issue for most Southern NGOs. In this sense, Focus is representative of a number of international and domestic 'pro-family' organisations which have a history of involvement in helping Christian conservatives live up to their conservative ideals, ${ }^{64}$ but have little experience in the area of development assistance (other than in the spiritual sense).

Both Focus and the FRC have official NGO status at the UN. As with CWA, another challenge faced by Focus and FRC's involvement at the UN is to justify its

\footnotetext{
${ }^{60}$ See FRC's and Focus on the Family's IRS Form 990s from 2004 to 2007.

${ }^{61}$ Buss and Herman, op. cit., p. xxviii.

${ }^{62}$ See Johnson, op. cit. for a useful analysis of Dobson's 'Biblical submission.'

${ }^{63}$ See Shah, T. S. (2004) 'The Bible and the Ballot Box: Evangelicals and Democracy in the "Global South," SAIS Review, vol. 24, no. 2.

${ }^{64}$ See for example, www.exodus-international.org for 'freedom from homosexuality,' www.familydynamics.net for a list of 'pro-family' organisations which offer marriage advice, for a list of organisations involved in 'curing sexual addiction' see www.afa.net/pornography/addiction.asp [all accessed 04/03/09] to name just a few of the numerous 'pro-family' helping/ministering organisations.
} 
activities at the UN to its domestic base, given the traditionally anti-UN and antiMuslim stance of many in the US evangelical community. ${ }^{65}$ With CWA, Focus and the FRC are the major Protestant organisations involved in 'pro-family' politics outside of the US. Any analysis of international 'pro-family' groups without Focus and FRC would potentially miss some of the most fundamental ideas holding the 'pro-family' movement together.

\section{The Howard Center for Family, Religion and Society}

Allan Carlson runs the Howard Center from Rockford, Illinois. Carlson is described as 'more of an academic than a global organizer, ${ }^{, 66}$ and usually refers to himself as a social historian rather than a 'pro-family' activist. Despite this disclaimer, Carlson served on the National Commission on Children under the Reagan Administration, ${ }^{67}$ and is a prolific speaker and writer on 'pro-family' issues. Previously on the board of the Rockford Institute, Carlson and his colleague John A. Howard left the organisation in 1997 and set up the Howard Center.

The Howard Center's purpose is

'to provide research and understanding that demonstrate and affirm family and religion as the foundation of a virtuous and free society. ${ }^{68}$

The website states that the organisation is independent from 'any particular religion, organization, or political group. ${ }^{69}$ Carlson himself is a Lutheran, and the board of the Howard Center contains people from many different religious backgrounds. The organisation has strong connections to the Mormon 'pro-family' movement: Dallin Oaks, one of the Twelve Apostles of the Mormon Church, is one of a number of influential Mormons sitting on the board of the Howard Center. ${ }^{70}$ Carlson himself has what Butler calls a 'close working relationship' with Dr Richard Wilkins, former director of the World Family Policy Center at Brigham Young University. ${ }^{71}$

\footnotetext{
${ }^{65}$ As Butler notes, Dobson promoted the Left Behind series, which lays out an Armageddon scenario in which a charismatic UN Secretary General is revealed as the Antichrist. Butler, op. cit., p. 112. 
Though this organisation operates on a relatively small (but growing) annual budget, ${ }^{72}$ the Howard Center is a hive of scholarly activity. The Howard Center's publications include The Family in America and The Religion and Society Report. The former is a monthly report which summarises recent research on family issues, couched in predominantly secular language, whilst the latter takes on a more explicitly Christian tone in its analysis of the impacts of social change. ${ }^{73}$ As well as operating a massive library of 'pro-family' articles, speeches and other publications, the Howard Center is active at the UN as an official NGO. Most importantly, the Howard Center organises the WCF and runs the official WCF website and publications.

More than the other organisations considered here, the Howard Center generates ideas and arguments that provide the 'pro-family' movement with what Buss and Herman call its 'intellectual sustenance. ${ }^{74}$ Carlson, in particular, reflects on a number of social and economic issues with more depth and sensitivity than others in the movement. He acknowledges the tensions with the Christian Right's alliance with neo-conservatives in the Republican Party, and makes no secret of his antiindustrial sentiments. Carlson sees himself as a conservative who holds traditional values, but his nostalgia and agrarianism emphasise an attachment to different traditions than those of Dobson and CWA.

Another point of difference between the Howard Center and others of the Protestant Right is Carlson's attitude towards the role of government. His promotion of 'family-friendly' policies, such as income-splitting and personal tax exemptions for married couples with dependent children, marks a divergence from other evangelicals. ${ }^{75}$ Though he does not support the 'Swedish model,' he emphasises the potential benefits of socialising the cost of having children (though through tax

\footnotetext{
${ }^{72}$ While the Howard Center's 2004 tax return showed an income of under $\$ 500,000$; by 2007 this had increased to well over \$1 million. The Howard Center for Family, Religion and Society 2004, 2005, 2006 and 2007 Calendar Year IRS Form 990, Return of Organisation Exempt from Income Tax Forms.

${ }^{73}$ See Buss and Herman, op. cit., p. xxix for more on these publications.

${ }^{74}$ Ibid, p. xxix.

${ }^{75}$ Income-splitting is a taxation system which reduces the tax paid by families in which one spouse cares for dependent children on a full-time basis. According to this system, a working partner supporting a wife or husband at home with children 'splits' their income, so that they are both taxed at the much lower rate which corresponds to half of the working person's income, thus the couple pays substantially less tax overall.
} 
relief, not income redistribution). This is connected to his investment and confidence in European countries as potential 'pro-family' allies, which also sets him apart from many others in the movement who have given up the continent as irredeemably 'lost.'

These five organisations and their offshoots represent the different religious sectors of the 'pro-family' movement and the different ways that 'pro-family' organisations are globalising. Their varied emphases on different policy areas corresponds to the breadth of issues with which the movement as a whole is concerned. They also embody different - and in some cases opposing - perspectives on how to deal with the issues they face. Although other organisations important to the movement are omitted from this study, ${ }^{76}$ I consider the groups chosen to be a representative sample.

\section{Part II: How the texts are used}

These organisations and their motives for global activism could arguably be examined (and indeed similar studies have been pursued) using psychological or sociological methods. I have chosen a political science approach because it highlights the most important aspects of the movement's successes: globally active 'pro-family' organisations are elite agenda-setters, attempting to bring about social change and increase their influence relative to progressive organisations. Before I describe my methods in more detail, I will briefly discuss the ways that psychologists and sociologists have addressed this question and how my approach differs from theirs.

\section{Interview techniques}

A number of political psychologists have attempted to answer the question of how Christian Right beliefs and motivations work. Kristi Andersen's (1988) study seeks to answer a similar question about 'pro-family' organisations as this thesis: what are the sources of 'pro-family' ideology? ${ }^{77}$ Her analysis is an attempt to understand the cognitive processes through which individuals' 'pro-family' political stances

\footnotetext{
${ }^{76}$ Prominent organisations such as the World Family Policy Center, Eagle Forum and United Families International might have been included in a broader study of US 'pro-family' organisations. ${ }^{77}$ Andersen, K. (1988) 'Sources of pro-family belief: a cognitive approach,' Political Psychology, vol. 9, no. 2, (June 1988).
} 
evolve. Andersen interviews her subjects using open-ended questions, with interviewees encouraged to explain their positions, and make links between statements. Her analysis is excellent, and she uncovers a number of similar journeys where interviewees went from being 'pro-choice' to being vocal and active members of the domestic US 'pro-life' movement.

Another important contribution to the psychology of 'pro-family' advocates is Christel Manning's (1999) book on how women involved in the domestic Religious Right movement 'grapple' with feminism in their own lives. ${ }^{78}$ Manning is interested in how conservative Catholic, Protestant and Orthodox Jewish women deal with inconsistency between their ideological views and the day to day demands and experiences in their own lives. She spent time in three different conservative communities, using in-depth interviews to ascertain how conservative women of faith have responded to feminist ideas. Manning's subject matter may not seem to be directly relevant to this thesis. However, if we consider that one of the same issues that has motivated 'pro-family' activism at the international level - feminism - is a key factor in shaping how Manning's subjects identify themselves politically, then Manning's methods and findings could be expanded to explain the behaviour and ideology of 'pro-family' groups at the international level. In addition, ideological inconsistencies like the ones Manning describes in her analysis arise time and again in 'pro-family' texts. In these ways, Manning's methods may offer us a way to explain the behaviour and ideological views of 'pro-family' views at the global level.

In spite of the potential of interviews to uncover the reasons that 'pro-family' activists believe what they do, I do not interview 'pro-family' activists. For the purposes of this thesis, it is the statements that are made by elites once they are already established as activists that are of interest, rather than the cognitive processes by which individuals have arrived at their ideological positions. This is partly because these statements and the people who make them are leaders of 'profamily' culture and politics. As broadcasters of the 'pro-family' message, it is arguably less important to discover a general route by which they came to their

\footnotetext{
${ }^{78}$ Manning, C. (1999) God Gave us the Right: conservative Catholic, Evangelical Protestant, and Orthodox Jewish women grapple with feminism (New Brunswick, N. J.: Rutgers University Press).
} 
views, than to tease apart what their views are and how they seek to act upon them in the global realm. I take it as a given that the organisations have emerged on the global scene with a set of ideological commitments, and it is how and why these commitments change in the context of globalization that is of interest here. Though interviews and psychological studies of how the 'pro-family' brain works are an important step towards understanding the political behaviour and personal biographies of religious conservatives, they do not address the question of how conservative social movements see the world beyond the US and how they change as they become global actors.

\section{Sociological approaches}

Sociological approaches to this topic have also been used to understand the activism and ideologies of the Christian Right. Frameworks derived from Marx, Durkheim and Weber, along with other influential sociological models have been used to understand conservative religious movements in ways that could be potentially useful here. Building on their work, contemporary sociologists have usefully applied these frameworks to understand the activities of the Christian Right. What follows is a brief description of four sociological approaches to the globalization of 'pro-family' organisations, and my reasons for not utilising these methods in this thesis.

Marxist approaches to religion emphasise that religion acts as a palliative for the alienating effects of the capitalist mode of production. Carolyn Gallaher's excellent study of the domestic Religious Right picks up on this theme. ${ }^{79}$ She makes the very plausible argument that working-class people find comfort from the economic anxieties wrought by globalization in the 'remasculinization' offered by Religious Right ideology. ${ }^{80}$ The same approach could be use to understand the popularity of 'pro-family' ideas in the global South. However, while this framework may offer an

\footnotetext{
${ }^{79}$ Gallaher, C. (2004) 'The Religious Right Reacts to Globalization,' in Tétrault, M. A. and R. A. Denemark (eds.) Gods, Guns and Globalization: Religious Radicalism and International Political Economy, International Political Economy Yearbook, Vol.13 (London: Lynne Rienner), pp. 31-55. ${ }^{80}$ This mirrors the observation made by Rosalind Petchesky that feminists arguing for sexual and reproductive rights against their conservative religious opponents at the UN has been at the cost of using this energy to combat a macroeconomic agenda that jeopardises the ability of women to realise these rights. Petchesky, R. P. (2000) 'Reproductive and Sexual Rights: charting the course of transnational women's NGOs,' Geneva 2000 Occasional Paper no. 8, United Nations Research Institute for Social Development, p. 24.
} 
answer as to why people in the poorest countries seem so ready to accept the "profamily' message in the context of economic globalization, it does not cast light on why 'pro-family' groups themselves believe so strongly in 'remasculinization,' and what role it plays in their global agenda.

Another important contribution made by sociologists to this topic is their expansion of Durkheim's concept of 'anomie' to the literature on religion and globalization. In this framework, not dissimilar to the one described above, religion acts as a barrier against the erosion of norms and values which are challenged by the relativising force of globalization. As an explanation for the rise of religious fundamentalism in poor countries, sociologist Radhakrishnan suggests that a 'fast spreading anomie' compels increasing numbers of people to seek moral guidance and social connections in readily available 'religious banalities. ${ }^{81}$ As above, however, while this thesis may help to explain attraction to conservative ideologies under globalization, it has limited potential in uncovering why religious groups from rich countries seek to spread this particular set of 'banalities' across the globe.

Sociologists of religion in the Weberian tradition ${ }^{82}$ see globalization as a process through which the world is rationalised according to specific principles that trivialise local religious practices and defy the inviolability of the nation-state. As such, an argument could be made that the 'pro-family' movement is a defensive effort to safeguard against the encroachment of a global 'iron cage of rationality,' in which human heterogeneity is destroyed by an over-bureaucratised global society. Others picture this differently, seeing the spread of US style Christianity as one of the means by which the 'protestant ethic of capitalism' is exported. ${ }^{83}$ This framework is potentially useful in many ways, although it has little to say about why the focus on curtailing women's health and rights initiatives has been such a political success for 'pro-family' groups. Application of this framework would also be problematic if it ignored the ways in which 'pro-family' organisations are

\footnotetext{
${ }^{81}$ Radhakrishnan, P. (2004) 'Religion under Globalisation,' Economic and Political Weekly, vol. 39, no. 13 , pp. 1403 .

${ }^{82}$ See (among others) Ritzer, G. and T. Stillman, (2003) 'Assessing McDonaldization, Americanization and Globalization,' in Global America? The Cultural Consequences of Globalization, Ulrich Beck et al. (eds.) (Liverpool: Liverpool University Press), pp. 30-48. ${ }^{83}$ See for example, Brouwer, Gifford and Rose (1996) Exporting the American Gospel: Global Christian Fundamentalism (Routledge: New York and London).
} 
themselves attempting to homogenise the social practices of the world according to their own rationalised schema.

Some sociologists who study social movements have offered 'status politics' as a means of explaining why certain movements develop as they do. This approach suggests that disgruntled individuals who perceive that their social status has been devalued form protest movements to restore themselves to their original position. The status politics framework has been fruitfully applied to the domestic Christian Right in the context of the anti-pornography, ${ }^{84}$ anti-abortion, and anti-gay ${ }^{85}$ aspects of the movement. ${ }^{86}$ In the context of 'pro-family' organisations moving beyond the US, status politics theory would suggest one of two explanations for this movement: either 'pro-family' groups are globalising as a means of redressing their loss of status at home, or they at one stage perceived their ideology as one of global importance and seek to restore it to that position. There is likely to be some truth to both of these explanations. In terms of the first, as was discussed in the previous chapter, the end goal of political 'pro-family' activism may not be limited to the restoration of the organisation's domestic standing. In that case, an approach that relies on status politics will miss the aspects of global change which the organisations desire as ends in themselves. In terms of the second explanation, it is true that in many parts of the world, the 'pro-family' ideology and way of life were more esteemed in the past than they are now. There is some evidence that "profamily' organisations see the UN itself as an institution that was once conservative in its stance towards the family. Yet to see these groups' activities as aimed at the re-establishment of 'pro-family' norms on a global scale is problematic, because these groups have portrayed the UN - and indeed the entire world outside the US as untrustworthy, hostile and secular for so long. Nor have the organisations or individuals themselves suffered a loss of status at the international level; their personal experiences during the Bush Administration have been the opposite. So

\footnotetext{
${ }^{84}$ For an example of this, see Greek, C. E. and W. Thompson, (1992) 'Antipornography Campaigns: Saving the Family in America and England,' International Journal of Politics, Culture and Society, vol. 5 , no. 4 .

${ }^{85}$ See, for example, Burris, V. (2001) 'Small Business, Status Politics, and the Social Base of New Christian Right Activism,' Critical Sociology, vol. 27, no. 1.

${ }^{86}$ See Moen, M. C. (2001) 'Status Politics and the Political Agenda of the Christian Right,' Sociological Quarterly, vol. 29, no. 3, for a critical analysis of status politics approaches to understanding the Christian Right's political agenda.
} 
although the status politics framework may be useful when applied to this issue at a general level, to rely on it as a working method would run the risk of obscuring important elements in the global emergence of the 'pro-family' movement.

Sociological methods and frameworks do have much in common with political science approaches, and could have been used here to unearth some extremely valuable ideas and findings about the motivations of 'pro-family' groups. Sociology offers different ways of understanding how people pick up ideas, incorporate them into their lives, and transmit them to others. Yet because this thesis is so concerned with discerning political ideologies, the analysis of the texts has been carried out using a political science framework which focuses on the discourse of elites. Given the lack of knowledge of the general public as to the global activities of many of these organisations, it seems reasonable to suggest that it is the elites of the movement that are responsible for its globalization. For this reason, it is the political ideologies of 'pro-family' activists which are the subjects of scrutiny in this thesis.

\section{Political Science}

There are a number of reasons to approach 'pro-family' ideologies through a political science framework. Ideologies are by nature political. Political ideologies make sense of the world (using a particular set of assumptions), and stipulate how people should behave in it. 'Pro-family' activists have clearly defined ideas about what is wrong with the world, a blueprint for how they would like it to be, and a plan as to how they will make it better.

Political ideologies take on even greater significance in a globalizing world. In the absence of an established and respected international legal framework, appeals to 'universally shared' symbols - such as the importance of families and motherhood - can be a powerful tool for agenda-setting. In their areas of interest, 'pro-family' organisations seek to affirm the 'natural family' as the global norm for the entire population of the world. In this effort, the organisations characterise events and entities as either contributing towards a 'pro-family' outcome, or an obstacle preventing the realisation of this desired end state. But making such claims in the global realm is also problematic: as Beyer notes, globalization brings into stark 
relief the fact that 'diverse ways of living are largely human constructions. ${ }^{87}$ In this environment, then, 'pro-family' organisations can be seen as competing for their ideology - which they argue is the most 'natural' one - to be elected as the blueprint for development. In this sense, the ideology of global 'pro-family' organisations can be examined in the same way as other political ideologies.

'Pro-family' ideologies have emerged from an environment of cultural conflict. These groups have gathered in response to political entities and social phenomena that they and their followers find repulsive. In the domestic realm and beyond it, these groups define themselves and shape their politics in opposition to others, as was discussed in the previous chapter. Moreover, the way these organisations shift their ideological priorities and adapt their discourse to new contexts over time is politically informed. This is a process in which the movement picks a path between maintaining adherence to certain key principles, and the necessity of taking strategic opportunities in a constantly changing environment. As the conflicts have gone on, the groups have adjusted both their priorities and their tactics, becoming astute political actors in the process.

Perhaps most importantly, these organisations (the units of analysis in this thesis) are best understood as political entities. Though they are all religious, their approach to politics is like any other international $\mathrm{NGO}^{88}$ (except for the obvious difference that most NGOs have progressive or liberal goals) with a political agenda that seeks to influence the way people behave. They could be considered as a distinctive set of Religious International NGOs, or 'RINGOs' as Boli and Brewington identify them. ${ }^{89}$ These authors write that RINGOs use religion both as a means and an end: their goals are a mixture of solely religious activities like proselytizing, and attempting to fix worldly problems through 'service to humanity within a God-given meaning and identity system.' 90 'Pro-family' organisations can

\footnotetext{
${ }^{87}$ Beyer, P. (1994) Religion and Globalization (London: Sage), p. 2.

${ }^{88}$ See the 'seven rules' of INGOs as described by the Union of International Associations: 'functional, voluntary, non-profit organisations with a high degree of autonomy from the state, a demonstrated international presence or orientation, and ongoing activities oriented to reasonably well-specified goals.' See Boli, J. and D. Brewington, (2007) 'Religious Organisations,' in Religion, Globalization and Culture, ed. by Peter Beyer and Lori Beaman (Boston: Leiden), p. 207. 
be understood to differ from ordinary RINGOs in that they see this 'service to humanity' in their effort to prevent (rather than offer) access to knowledge and services, and their attempts to bring down international organisations they see as harming the world's people. I suggest, however, that in their short history, 'profamily' organisations have shown more enthusiasm in conservative political activism and almost no interest in proselytizing (in the sense of saving souls). Because they have historically preferred to focus their efforts on proscribing and disrupting international development initiatives than providing services, and because they make an effort to play down their religious identities, these groups are best considered as a political movement of religious organisations.

\section{Discourse Analysis}

'Pro-family' organisations form a specific political community with shared goals, language, and ideas about the world. As such, discourse analysis provides an academic tool through which their 'friend-foe' politics can be identified and understood. A 'discourse' is usefully defined by Charlotte Epstein as

'a cohesive ensemble of ideas, concepts and categorisations about a specific object that frame that object in a certain way and, therefore, delimit the possibilities for action in relation to it. ${ }^{91}$

Discourses evolve in a process which reinforces successful categorisations and representations, through which 'realities are constructed, made factual and justified. ${ }^{92}$ Understanding the way these organisations represent the world enables observers to see how 'pro-family' ideology is changing over time, to see which symbols and ideas are believed to be of most significance, and to understand how 'pro-family' groups represent the ideologies of their opponents.

It should be noted here that 'pro-family' political discourse almost certainly involves misrepresentation, exaggeration and outright deception. How is it possible to discern the motivations of people within the 'pro-family' movement if we do not know whether what is said represents even the views of the person saying it, let

\footnotetext{
${ }^{91}$ Epstein, C. (2008) The Power of Words in International Relations: Birth of an Anti-Whaling Discourse, (Cambridge: Massachusetts Institute of Technology Press), p. 2.

${ }^{92}$ Lessa, I. (2006)' Discursive Struggles Within Social Welfare: Restaging Teen Motherhood,' British Journal of Social Work, iss. 36, vol. 2, p. 285.
} 
alone the entire movement? To this I would reply that the fact that a claim has been made publicly is what matters, rather than whether the claims themselves are sincere, or representative of the wider 'pro-family' community. An assumption here is that strategically or deliberately distorted characterisations of the world are still a part of 'pro-family' discourse, and therefore say something about the 'pro-family' view of reality. In other words, if 'pro-family' activists are scoring political points from what they believe are widely held perceptions of the world and the people in it - even if they do not believe these perceptions themselves - this still betrays a 'profamily' belief about the world. Regardless of the objective truth or otherwise of any given 'pro-family' representation then, persistent depictions of the world that ring false or seem intentionally distorted offer the observer an insight into the kinds of symbols and characterisations that 'pro-family' organisations want their adherents to accept. That particularly bizarre characterisations of the world are either picked up or ignored by the 'pro-family' public is also relevant, attesting to the boundaries of the discourse.

In this way, discourse analysis enables observers to perceive the ways that the "profamily' movement is changing over time. When these organisations pick up on new ideas and stop emphasising old ones, we get an indication of the way the movement is changing. These changes in direction may be responses to events and actors outside the movement, or the projection of ideas generated from within the movement. Some ideas remain consistent core beliefs, while others are amenable to change. This type of analysis can show which policy positions are likely to persist, and which are not.

While the use of discourse analysis is by no means restricted to political scientists, its ability to discern symbols and ideas within the language of a given political community makes it an excellent tool for understanding that community's political views. The 'pro-family' movement appears to be particularly attuned to the importance of symbols surrounding gender and families. Symbols and ideas arguably become even more important under globalization as the organisations appeal to (what they believe are) universally held morals and beliefs. 
Finally, discourse analysis enables an observer to see the world through the eyes of other people. This allows us to understand why international 'pro-family' activists do what they do. Considering the discourse of another political community means coming to terms with the different assumptions that the people within it make about the world and how they work in practice. Thorough analysis of their rhetoric should provide a sophisticated understanding of these organisations. Here I am making the assumption that it is possible to discern the driving forces of the 'pro-family' movement from the way its organisations write and talk about the world. This is part and parcel of treating these organisations as political entities; every complaint or positive comment these organisations make suggests that the world is a step closer or further away from the way they think it should be. From this point of view, the way social issues are represented within a group of people is responsible for - or at least indicative of - the political views of its members, and directs the group's activities to a large degree. If these representations are successfully picked up in the discourse, they reinforce the importance of certain symbols, the accepted meaning of words, and ultimately the direction of the movement itself.

The texts in this thesis are not read with any new or specially developed technique, and no particular type or theory of discourse analysis is intended to be invented or redefined here. The texts are simply gathered by the use of search engines on the websites of the five organisations under scrutiny, according to their relevance to the international or global outlook or agenda of these organisations. For example, texts for chapter five, on feminism, were found by searching for the words 'fem*, 'wom*,' 'masc*,' 'child*, 'girl*,' 'abort*,' 'sex*,' 'repro*' and 'health,' on all of the websites.'

\section{What this thesis does not cover}

My research does not provide a detailed description of the activities of the profamily' movement in terms of their attendance at international conferences, lobbying US politicians and so on. The efforts of international 'pro-family' organisations are discussed in detail in a growing number of books on the movement. Lee Marsden, for example, traces the activism of these international Christian Right organisations in 'Hijacking the Human Rights and Humanitarian 
Assistance Agenda,' a relatively descriptive chapter in his 2008 book on the foreign policy influence of Christian Right organisations. ${ }^{93}$

Butler's 2006 book Born Again also provides analysis of Christian Right positions and arguments at different UN conferences, showing the approaches the movement has taken with regards to a variety of issues. She sees herself as a 'participating observer' of the Christian Right, having represented progressive religious organisations at the UN for some years. My research, by contrast, maps the "profamily' ideological terrain and its complications. In this sense, then, this thesis is intended to complement Marsden and Butler's work on 'pro-family' activism, in that it provides a kind of theoretical or ideological narrative to the action they describe.

Nor does this thesis follow the activism of 'pro-family' organisations in order to discern the reasons for their success, as Butler does. Butler's effort to understand why 'pro-family' groups have been so successful focuses on the techniques and circumstances surrounding the rise of the international Christian Right. Butler is sensitive to the difficulties facing these groups as they attempt to build a conservative NGO network by creating alliances with conservative Muslim governments and organisations. Crucially, she explains the globalization of "profamily' groups largely in terms of the opportunity they have been given to do so. This she does well, and from a tactical point of view, Born Again provides a superb analysis of the strategic aptitude of Christian Right organising. This thesis does not attempt to analyse the success of the 'pro-family' movement or predict its future success using any particular political framework for doing so. In other words, while I highlight the changing course of 'pro-family' discourse and pay close attention to the issues that threaten to divide or hinder the movement, I do not attempt to calculate whether or why the movement is successful or not or speculate as to its future.

This thesis considers 'pro-family' texts from the websites of the groups described above from 1997 to the end of 2008. There are two main reasons for starting my

\footnotetext{
${ }^{93}$ Marsden, L. (2008) For God's Sake: The Christian Right and US Foreign Policy, Zed Books, London and New York, p. 145.
} 
investigation of the international 'pro-family' movement around 1997. The first WCF was held in Prague in 1997, and signals the beginnings of a formal effort to coordinate the global agenda of 'pro-family' organisations. The second reason is that the internationalisation or globalization of the movement arguably only begins in earnest around or after this time. C-Fam was created in 1997, as was the Howard Center. Though the other groups may have attended conferences at the UN before this time, they did not gain official ECOSOC accreditation or consultative status until after $1997 .^{94}$ I finish my analysis at the end of the Bush administration.

\section{Conclusion}

In this chapter and those preceding it, I have attempted to do a number of things. I have explained my intention to examine and understand the motivations of globally active 'pro-family' organisations, and justified this aim in terms of the profound effects that this movement has had since the late 1990s. ${ }^{95}$ These 'pro-family' NGOs are an elite group of conservative global actors who enjoy the support of the US Christian Right but do not necessarily have to justify their activities to their grassroots domestic supporters. I have described each organisation in detail and justified my selection process.

I have considered the 'pro-family' motivations offered by the academic literature on this movement and used what I see as the most useful and fitting of these to focus my research. From this analysis, four areas emerged as important ways of understanding 'pro-family' motivations. The first is globalization, which provides an understanding of the changing context under which 'pro-family' organisations see themselves as working. The second is the UN, which has been both the means through which 'pro-family' groups have come to see themselves as global actors, and a nemesis which characterises the dangers inherent in global space. The third is feminism, which has undoubtedly been a major ideological opponent against which global 'pro-family' activism has developed. The last is fertility, which brings together a number of different strands of 'pro-family' thought around population

\footnotetext{
${ }^{94}$ See http://esango.un.org/civilsociety/displayAdvancedSearch.do?method=redefine\&ngoFlag= for the different years that ECOSOC consultative status or accreditation was granted to these organisations [last accessed 22/08/09].

${ }^{95}$ In terms of timing, my research is weighted towards more recent 'pro-family' discourse. This is because Buss and Herman's research, which is similarly focused on 'pro-family' ideology, covers the period up to early 2003.
} 
control, secularism and development. In these chapters, I lay out the different ways that these areas have been discussed in 'pro-family' discourse and show how these perceptions may be changing. In considering the changing ways that 'pro-family' organisations consider the ideologies and the people that they oppose, we gain crucial insights into what the 'pro-family' movement believes about itself and its role in the globalizing world. 


\section{Chapter Three: 'Pro-family' views of Globalization: danger meets opportunity}

'... the process of globalization to which we all seem to be committed will lead to the largest "state" of all, the World State, and that state will inevitably be despotic. ${ }^{\prime}$

The Howard Center, 2001

'I quite agree with Abraham Kuyper ... "There is not a square inch in the whole domain of our human existence over which Christ, who is Sovereign over all, does not cry: Mine!", ,2

The Family Research Center, 2001

Globalization is a massive and convoluted topic. Academics have suggested a number of different ways of understanding the meaning and practice of globalization. One of the first, sociologist Roland Robertson, described globalization as 'the compression of the world into a single place. ${ }^{3}$ Other scholars have preferred to characterise globalization in terms of the increasing frequency with which things and information travel across and between regions of the world. ${ }^{4}$ Alternatively, Philip McMichael sees it in more political terms, as a 'project' in which the increasing reach and influence of global elites is achieved through the exploitation of various inequalities. ${ }^{5}$ All of these definitions are valid (and compatible), from certain perspectives.

In this chapter I attempt to identify how 'pro-family' organisations understand globalization. As was discussed in chapter one, I assume that how organisations define globalization has a significant impact on how they behave. Finding the

\footnotetext{
${ }^{1}$ The Howard Center (2001) 'Large and Small States: Globalization,' The Religion and Society Report, vol. 18, no. 10, October 2001. See http://www.profam.org/pub/rs/rs 1810.htm [last accessed 08/09/09].

${ }^{2}$ Bolt, J. (2001) 'The Culture War in Perspective: Lessons from the Career of Abraham Kuyper,' Witherspoon Lecture, 15 August 2001, Family Research Council, http://www.frc.org/get.cfm?i=WT01G1, [last accessed 05/04/09].

${ }^{3}$ Robertson, R. (1992) Globalization: Social Theory and Global Culture (London: Sage) p. 6.

${ }^{4}$ This is a short version of one of five characterisations of globalization offered by James A. Beckford, (2004) 'Religious Movements and Globalization,' in Cohen, R. and S. M. Rai (eds.) Global Social Movements, (London: Continuum), p. 170.

${ }^{5}$ McMichael, P. (2004) Development and Social Change: A global perspective, $\left(3^{\text {rd }}\right.$ edn). (Thousand Oaks, CA: Pine Forge Press), p. 238.
} 
'truest' account of globalization is less important than understanding what 'profamily' leaders believe about the phenomenon. For this reason, I use all of the descriptions above as 'working definitions' of globalization as I seek out the different ways that 'pro-family' activists understand globalization.

Much has been written on how religious movements fare in the context of globalization. Because religions tend to appeal to universal moral principles, and globalization challenges the universal applicability of such claims, religious movements can struggle to maintain their moral authority in an increasingly relativistic social environment. 'Pro-family' organisations, with their strong history of moral declarations and their firm belief in the rightness and wrongness of certain behaviours, seemed predestined to suffer bitterly under globalization. Yet they have not. This chapter is an attempt to understand why this is so. It examines the ways that 'pro-family' organisations have characterised globalization, in order to discern how the groups reconcile their ideological positions and their identity with their new roles as global actors.

Most 'pro-family' leaders see globalization as a secularising process. Globalization, they argue, is both anti-Christian and anti-tradition. When it is not associated with liberal international organisations and 'globalists,' globalization is very occasionally conflated with anarchy in 'pro-family' discourse. As a result, globalization (as it is presently experienced) is at odds with the central values of Christian conservatism: the primacy of tradition and divine authority in ordering social space.

Where they see globalization as unavoidable, 'pro-family' discourse offers its own vision of how the process should be guided or shaped (insofar as this is possible). This vision sees enlightened global actors using 'pro-family' and 'Judeo-Christian' principles as a guide to make appropriate decisions for their constituencies. These principles, say the organisations, are preferable both to the approaches taken by liberal leaders of international institutions who are sometimes assigned as 'globalists,' and to a laissez-faire globalization that is controlled by nobody. Desiring neither anarchy nor a liberal world government, 'pro-family' organisations assume the responsibility of saving the world from 'anti-family' forces as their own. 
Policy positions on globalization seldom emerge with this degree of clarity, however, with the overwhelming approach to globalization clouded in ambiguity, confusion and apprehension. 'Pro-family' interpretations of globalization in this chapter show a movement that is quite uncertain of how to deal with this phenomenon. Inconsistencies and outright hypocrisies are rife. It is clear that 'profamily' organisations are not always talking about the same aspects of globalization when they make their claims for or against it. Globalization, like all forms of political change, is never treated neutrally in 'pro-family' discourses.

Nevertheless, a fledgling 'pro-family' agenda with regard to globalization can be discerned. Where political positions do become apparent, they veer in two directions. Some 'pro-family' arguments state that the process of globalization is in itself destabilising and needs to be arrested by appeal to government protection, whilst others speak to the 'pro-family' opportunities that emerge from this instability. Proponents of the former position advocate strong government and small communities, whilst advocates of the latter encourage the outreach of US 'profamily' organisations to areas most affected by globalization, in order to encourage the 'grassroots' uptake of the 'pro-family' message. These are very different agendas, but both have been advanced across the 'pro-family' spectrum, to various degrees.

This chapter is divided into three sections which analyse 'pro-family' texts that relate to globalization. The first section asks: how do 'pro-family' leaders interpret globalization? The second asks: which aspects of globalization are seen as redeemable? The way the groups are changing their perspectives over time is also considered throughout the chapter.

\section{Part I: How do 'pro-family' leaders interpret globalization?}

According to 'pro-family' organisations, globalization is mostly a negative phenomenon. 'Pro-family' thinkers who consider globalization tend to see it as a process that reduces both the freedom of people to live their lives as they choose, and the stability of the communities in which they live. The texts differ widely as to what it is that is exerting control over people's freedom, how this influence will be 
applied, and whether there are agents of globalization who are responsible for this reduction of freedom. As already noted, there is a wide variety of 'pro-family' perspectives on what globalization is, and what is driving it. This section is divided into six categories, which have emerged from this examination of 'pro-family' discourse: globalization as corporate-driven, globalization as external regulation, globalization as US-lead, globalization as materialism, globalization as spreading the 'culture of death,' and globalization as secularism.

\section{Globalization as corporate-driven}

Corporations are occasionally highlighted in 'pro-family' texts as playing a role in promoting an increasingly repressive global system, and they are largely seen to be unreliable entities in terms of protecting tradition and religion. Yet 'pro-family' groups do not display any expectation that corporations should act in a particular way, other than in the direction of maximising profits. Overall, texts that are critical of corporate-lead globalization tend to highlight the liberal attitudes of CEOs as the reason that globalization has what they see as 'anti-family' outcomes, rather than the structures or profit-seeking motives of corporations themselves.

The Howard Center stands out among 'pro-family' organisations as interpreting corporate globalization as problematic in itself, in that corporations inevitably increase their power relative to nation-states, local religious communities and individuals. The author of a 2002 Religion and Society report suggests that 'globalization, in which international corporations control the destiny of smaller nations and sometimes of ours, ${ }^{6}$ leads to the breakdown of national sovereignty. This is through "the power of international commerce, ${ }^{7}$ in which corporations are able to impose their will on the governments of smaller countries. The author sees this as a serious problem that threatens the US, though he concludes that 'for the time being, at least, it is Washington, not Wall Street, which rules. ${ }^{8}$ Globalization looms, but has not yet taken over. Thus with resolve and political action, people can still resist the detrimental effects of globalization by encouraging governments to

\footnotetext{
${ }^{6}$ The Howard Center (2002), 'Suicidal Democracy and Globalism,' The Religion and Society Report, vol. 19, no. 3 March, 2002. See

http://www.profam.org/pub/rs/rs_1903.htm?search=globalization\&opt=EXACT [last accessed $11 / 08 / 09]$.

${ }^{7}$ Ibid.

${ }^{8}$ Ibid.
} 
rein in corporations. Economically speaking at least, then, the Howard Center is moving towards the prioritisation of the nation-state system over any political commitment to unregulated capitalism.

C-Fam, on the other hand, interprets the role of corporations in the process of globalization more ambiguously. Big business is only identified as a global threat when its executives pursue political goals that are incompatible with those of the Christian Right. One C-Fam Friday Fax warns that '[i]ncreasingly... with the rise of globalization, the left is coming to see big business as a very powerful engine for liberal social change. ${ }^{9}$ Another Friday Fax bemoans the degree of cooperation between UN children's agency UNICEF, and corporations that they argue are run by executives with liberal tendencies: 'These [UNICEF] programs [promoting gender equality] frequently use financial and broadcast assistance from such media giants as Walt Disney, Warner Brothers, and Turner Broadcasting. ${ }^{10}$ Globalization is seen as being negative in this sense, because it facilitates the institutional 'teaming-up' of rich and influential 'anti-family' forces, not because it enables corporations and individuals to broadcast their agenda globally per se.

Another C-Fam author takes issue with liberal leaders of international corporations because he sees corporate leaders as betraying their long-term profit mandates by supporting pro-choice organisations. The author is perplexed by the idea that 'manufacturers that rely upon an increasing population of children, for instance, frequently give their money to groups that support and promote population control.' ${ }^{11}$ Rather than stress the moral dimensions of abortion and contraception, this author emphasises that the promotion of such policies counteract the interests of shareholders and in general, the economy as a whole. ${ }^{12}$ Here C-Fam does not question the appropriateness of global capitalism in promoting a 'pro-family/pro-

\footnotetext{
${ }^{9}$ Ruse, A. (2000) 'Corporate Investments May Be New Conduit for Abortion in Developing World,' Friday Fax, January 7, 2000, vol. 3, no. 8. Catholic Family and Human Rights Institute, available at http://www.c-fam.org/publications/id.123/pub_detail.asp, [last accessed 11/08/09].

${ }^{10}$ Ruse, A. (1998) 'UNICEF Uses American Media Giants to Spread Feminism to Developing World,' Friday Fax, October 2, 1998, vol. 1, no. 51. Catholic Family and Human Rights Institute, available at http://www.c-fam.org/publications/id.60/pub_detail.aspl [last accessed 11/08/09]. ${ }^{11}$ Ruse, A. (2000) 'Corporate Investments May Be New Conduit for Abortion in Developing World,' Friday Fax, January 7, 2000, vol. 3, no. 8. Catholic Family and Human Rights Institute, available at http://www.c-fam.org/publications/id.123/pub_detail.asp [last accessed 11/08/09].

${ }^{12}$ This is connected to the 'demographic winter' approach taken by 'pro-family' organisations, which is discussed at length in chapter six.
} 
life' society, seeing the two as highly compatible. Thus it is the agents, rather than the process, of globalization that is the problem for C-Fam.

\section{Globalization as external regulation}

Concerned Women for America (CWA) depictions of globalization are quite perplexing. Almost all CWA texts before 2004 mentioning globalization focus exclusively on the UN and its shortfalls. In one 2002 article that tangentially discusses globalization, 'UN takes on Population and Free Markets,' CWA senior fellow Janice Crouse warns that international discussions on globalization equate to calls for greater UN control:

'Group I [of three groups preparing for a UN-sponsored international conference on sustainable development] will focus on socialistic world-government anti-poverty schemes. Group II will focus on globalization-UN control of trade and finance in the world economy. ${ }^{13}$

Here globalization is intrinsically linked to - even defined by - attempts to control it. The UN is seen as an entity that seeks to control the world through its role as a regulatory body, imposing its ideological agenda on the world's population. This suggests that (at this time, at least) CWA does not distinguish between globalization and what Buss and Herman refer to as 'globalism': the drive to create a 'New World Order' based on socialist, feminist and environmentalist principles. ${ }^{14}$

Another article by Crouse in 2002 suggests that globalization is one of the UN's 'causes.' Crouse is concerned with the degree to which the UN is able to influence global attitudes and beliefs. In her words, the UN 'flaunts its causes: gender mainstreaming and gender equality, reproductive rights and services, globalization and reparations.' 15 Moreover, the UN is opposed to Western affluence and capitalism, says Crouse: 'According to the UN, capitalism, free trade, private

\footnotetext{
${ }^{13}$ Crouse, J. S. (2002) 'UN Takes on Population and Free Markets,' January 1, 2002, Concerned Women for America, http://www.cwfa.org/articledisplay.asp?id=1951\&department=CWA\&categoryid=nation [last accessed $11 / 08 / 09]$.

${ }^{14}$ See Buss, D. and D. Herman, (2003) Globalizing Family Values: the Christian Right in International Politics, (Minneapolis: University of Minnesota Press), pp. 20-25 for more on Christian Right interpretations of globalism.

${ }^{15}$ Crouse, J. S. (2002) 'UN/Hollywood Half-Truths', January 1, 2002, Concerned Women for America, available at http://www.cwfa.org/articles/1954/CWA/nation/index.htm, [last accessed $11 / 08 / 09]$.
} 
enterprise and entrepreneurship are all sources of environmental and developmental problems around the world. ${ }^{16}$ Thus in Crouse's view at this time, globalization is not capitalism writ large, it is the UN's response to it.

Later CWA articles on globalization are not much clearer than their predecessors. In an article written four years later in response to a publication by the US National Council of Churches (NCC), Crouse still makes a connection between globalization and economic redistribution from rich to poor countries:

'[the NCC report suggests that] global trade and global aid are essential for greater financial equity around the world; translation: Globalization means robbing the US and giving to undeveloped nations. ${ }^{, 17}$

Clearly Crouse is opposed to globalization if it means redistributing money away from the US. Crouse's issue with globalization is still to do with the efforts of progressives to mitigate its unequal effects, rather than the process itself. ${ }^{18}$

This is established further in a 2006 article by Crouse called 'the big G Globalization.' In this article, her emphasis on the UN's role in globalization has disappeared but she persists in seeing globalization in terms of the redistributive policies advanced by her opponents. In a critique of a United Methodist study which (among other things) opposes the increasingly elite control of global financial power, Crouse warns that the study's criticism of unfettered capital flows is an unspoken recommendation for regulation of the international economy by the

\footnotetext{
${ }^{16}$ Ibid.

${ }^{17}$ Crouse, J. S. (2006) 'Misguided Attempts to Eradicate Global Poverty: An analysis of the National Council of Churches Study Guide on the Millennium Development,' Concerned Women for America, 15 August, 2006. Available at http://www.cwfa.org/articledisplay.asp?id=11307\&department=BLI\&categoryid=reports [last accessed 11/08/09].

${ }^{18}$ It is noteworthy that 'global trade' is also considered to mean 'robbing the US,' given CWA's stated preference for trade as a means of economic development. See, for example, Crouse, J. S. (2002) 'Stumbling Blocks on the road to Johannesburg,' January 1, 2002, Concerned Women for America. Available at http://www.cwfa.org/articledisplay.asp?id=1955\&department=CWA\&categoryid=nation. See also Crouse, J. S. (2002), 'UN Takes on Population and Free Markets,' January 1, 2002, Concerned Women for America, http://www.cwfa.org/articledisplay.asp?id=1951\&department=CWA\&categoryid=nation [both accessed 12/08/09].
} 
UN, or, she scoffs, by 'a cabal of third world dictators. ${ }^{19}$ Perhaps unsurprisingly, Crouse comes out in full support of global capitalism:

'Ultimately, though, the study realizes that globalization [is] about politics globalization means privatization. This statement is fraught with horror! ${ }^{20}$

By 2006, then, Crouse sees globalization as an economic experience, occurring despite the involvement of the UN rather than because of it. She is still on the watch for would-be regulators, but seems far happier with laissez-faire economic globalization than she is with any regulatory involvement. Even though she does acknowledge the role of private companies in globalization, missing from any CWA texts is an indication of how globalization is promoted or affected by US interests. Globalization remains something of a problem, but what exactly it is and who is causing it is not ground that Crouse is comfortable covering.

The connection between globalization and perceived 'globalists' who seek to control the US is shared by other 'pro-family' authors. Concern that globalization is an effort to standardise norms and practices the world over is prevalent in earlier Howard Center texts. One of the 'dangerous features' of globalization, according to a 2000 Religion and Society Report, is the 'trend to submerge particular national sovereignties and ethnic identities into a multicultural "new world order.", 21 This is 'a project of global planification, standardization, or, as it is increasingly called, globalization. ${ }^{22}$ Even though this author's comments emerge as he discusses a disagreement in the global banking sector, his concern about globalization is wholly with its supposed homogenisation of culture, not its economic effects. Multiculturalism (which is equated with globalization) is thus seen as a form of newspeak, in which the illusion of many cultures in the same context hides a social reality in which differences are actually penalized, and freedoms curtailed.

\footnotetext{
${ }^{19}$ Crouse, J. S. (2006) 'The Big G - Globalization: Demagoguery about "America's Economic Exploitation",' August 16, 2006, Concerned Women for America. Available at http://www.cwfa.org/articledisplay.asp?id=11328\&department=BLI\&categoryid=nation [last accessed 12/08/09].

${ }^{20}$ Ibid.

${ }^{21}$ The Howard Center (2000) 'Tragedy and Masquerade,' The Religion and Society Report, vol. 17, no. 1, January 2000. See http://www.profam.org/pub/rs/rs 1701.htm?search=Islamic\%20family\&opt=ALL [last accessed $12 / 08 / 09]$.

${ }^{22}$ Ibid.
} 
This resonates with the central concern that most 'pro-family' groups have with pluralism and tolerance, which are the same weapons their opponents wield in their domestic battles. On a global scale, however, these values take on a more important role. As noted previously, globalization has a tendency to relativise claims to religious morality, making accusations of immorality and offence subject to debate rather than accepted as moral truths. Given that conservative groups inevitably suffer more from anti-discrimination laws and 'enforced' tolerance, purely because they are offended by a wider range of behaviours than liberals are, 'pro-family' groups equate tolerance with tyranny, paradoxically seeing any global imperative towards tolerance and pluralism as coming at the cost of the diversity of moral and religious beliefs.

Globalization in this form, then, is seen as unavoidably despotic to 'pro-family' organisations. Unlike other 'pro-family' activists, early Howard Center texts support national sovereignty without reserve; globalization and its promoters threaten the freedom enjoyed in the nation-state system. External forces are seen as regulatory, and threaten that freedom. In 2003, a Howard Center author suggests that putting the brakes on globalization is an important step in promoting and protecting domestic harmony within the US. He writes that

'Globalization ultimately means the end of national sovereignty, and without a principle of sovereignty, no nation, not even the richest in the world, will be able to fulfill the fundamental duty of a state to preserve domestic tranquility[sic]. ${ }^{23}$

The group thus rejects globalization on the grounds that it promotes a set of global norms and rules enacted from beyond the US nation-state. Thus again we see the idea that there are central planners behind globalization. While C-Fam and HLI see their purpose as defending the freedoms of people in developing countries from external secular forces, Howard Center authors emphasise that this same protection needs to be upheld for US citizens too. In this view, all nations are fragile in the wake of globalization, and require strong states to maintain domestic cohesion.

\footnotetext{
${ }^{23}$ The Howard Center (2003) 'The Hidden Violence of Globalization,' The Religion and Society Report, vol. 20, no. 4, April 2003. See http://www.profam.org/pub/rs/rs 2004.htm?search=globalization\&opt=EXACT [last accessed 16/08/09].
} 
How governments are supposed to safeguard their populace from external regulation is left unexplained, however. External regulation is characterised in different and sinister ways, some of which are virtually impossible to prevent. One Howard Center author writing in 2000 has the following to say about the way the world is changing:

'While democracy and liberty appear to be triumphant on a planet from which authoritarian regimes have largely been banished, censorship and manipulative control are returning in force under other names... the technology of communication is now, more than ever, playing an ideological role to muzzle thought... The true masters of the world are no longer those who control the appearances of political power. $^{24}$

While the meaning of some parts of this quote may be somewhat obscure, the author seems to arrive at the conclusion that with increased communication technology, the individual is no longer an active agent; he or she is just a mindless conduit for information. The active role is taken, curiously, by technology. Put another way, the author sees a group of people - presumably the very technologically savvy - benefiting from people's decreased ability to think for themselves. With an excess of information and a lack of access to divine truth (or an inability to recognize it amongst so much content), the author sees individuals as at the mercy of those in control of communication technology. Paradoxically, the same technology used by the groups to advance their views on the 'natural family' is also to blame for inhibiting diversity and freedom. That powerful people or groups, as the author suggests, are increasingly out of sight and unaccountable gives little clue as to who they might be, other than that they are not the people who 'should' hold power.

Other Howard Center texts stress that external regulation comes in the form of a global democracy. A report from 2002 suggests that globalization means the surrender of individual and cultural sovereignty; a global regulation of culture that needs to be arrested:

\footnotetext{
${ }^{24}$ The Howard Center (2000) 'In addition to which,' The Religion and Society Report, vol. 17, no. 1, January 2000. See http://www.profam.org/pub/rs/rs 1701.htm?search=true\%20masters\&opt=EXACT [accessed 15/08/09].
} 
'Americans fascinated by globalization and multiculturalism should consider what it will mean to allow our own lives to be regulated by organizations with little or no appreciation for many of our most cherished values. ${ }^{25}$

Stressing the dictatorial elements of a posited global government, this author sees global regulation, undertaken by a foreign authority, as a deeply troubling concomitant of globalization. Such an authority may be both legitimate and problematic.

Another 2002 text from this organisation sees globalization as dangerous precisely because of its democratizing effects. In a refreshingly candid manner, this author suggests that the globalization of democracy will be seriously harmful to those who currently hold wealth and power:

'... the globalization of democracy will inevitably mean that decisions in our own wealthy nations will not be made by their own citizens, but by the far more numerous poor of the world. ${ }^{26}$

The same sentiment is expressed in an article written a year later, which acknowledges that

'with fewer than 300 million people in the United States, we make up perhaps five percent of the world's population, and in a really globalized world we shall be outvoted with regularity and required to surrender the privileges that our wealth and power have accorded us. ${ }^{27}$

Hence for the Howard Center, the case for upholding national sovereignty is not only that it maintains freedom in general, but also that it particularly upholds the disproportionately far-reaching liberties of the US. This is especially the case for developing countries, the 'numerous poor,' who likely see their weak economic position as being, at least in part, a result of the West's extensive wealth and power. The interpretation here of 'real' globalization as being truly democratic (in the

\footnotetext{
${ }^{25}$ The Howard Center (2002) 'Going it alone,' The Religion and Society Report, vol. 19, no. 9, September 2002. See

http://www.profam.org/pub/rs/rs_1909.htm?search=cherished\%20values\&opt=EXACT [accessed $15 / 08 / 09]$.

${ }^{26}$ The Howard Center (2002) 'Suicidal Democracy and Globalism,' The Religion and Society Report, vol 19, no. 3, March 2002 http://www.profam.org/pub/rs/rs_1903.htm?search=globalization\&opt=EXACT [12/11/06].

${ }^{27}$ The Howard Center (2003) 'Involuntary Self-Abnegation,' The Religion and Society Report, vol 20, no. 4, April 2003. http://www.profam.org/pub/rs/rs_2004.htm?search=globalization\&opt=EXACT [12/11/06].
} 
sense that rich and powerful countries can be outvoted and forced to toe the line by poor and weak ones) is an interesting one. Not only is it a future the organisation does not look forward to in 2002, it is an entirely different vision of globalization than that imagined by most other opponents of globalization, who might welcome a democratic alternative to the repressive power relations emerging from the new global reach of corporations. The Howard Center does not approve of the corporate version either, as has already been established, though it is noteworthy that the organisation also takes issue with efforts to control corporate globalization. Thus Howard Center authors writing around this time all seem to suggest that globalization is likely to be harmful to US interests, whether through the tyranny of global corporations, the direct surrender of procedural power (as we would be likely to witness in a global democracy), or less tangibly, the ideological oppression emerging from increasing access to information.

However, no solution to globalization is offered by the Howard Center, and these ideas are left undeveloped by its contributors. Though they are common around the turn of the century, Howard Center texts discussing globalization appear only until around 2003-4, by which time reference to this previously popular topic seem to vanish. ${ }^{28}$ Howard Center authors may have decided that globalization is too slippery or treacherous a concept to continue to discuss. There is some evidence, however, that the organisation's concern with democratic globalization as documented above has changed. As Carlson notes in 2008 (this time writing for Focus), the staunchest allies of 'pro-family' forces in the 'battle for traditional families' are 'people of color' in the developing world. ${ }^{29}$ Moreover, writes Carlson, 'the $21^{\text {st }}$ century culture war's battle lines will be neither racial nor national... if traditionalists unite, their passion for life will provide not only moral authority but numerical superiority. ${ }^{30}$ This seriously complicates the Howard Center's stance on globalization. If this 'pro-family' organisation continues to claim the ideological allegiance of the global population, its days as a staunch opponent of globalization are over. I return to this development in the final part of this chapter.

\footnotetext{
${ }^{28}$ One 2005 article which refers to globalization is available on www.profam.org, but the majority of texts which discuss globalization appear between 2000 and 2003.

${ }^{29}$ Carlson, A. and P. Mero (2004) 'Traditional Families of the world, unite!' Focus on the Family Issue Analysis, available at http://www.citizenlink.org/FOSI/marriage/A000002224.cfm [last accessed 14/08/09].

${ }^{30}$ Ibid.
} 


\section{Globalization as US-lead}

Many 'pro-family' perspectives on globalization acknowledge that the US is leading globalization in some way, although the emphasis is on cultural globalization. HLI's Euteneuer is concerned about the spread of US cultural norms via both political and economic channels. He sees liberalisation of laws concerning sexuality and reproduction in the US as directly encouraging such changes in other countries. Consider the following excerpt from a speech given by Euteneuer in Sydney in 2003:

'Less than a month ago the US Supreme Court legalized sodomy as a right of privacy, opening the door to gay marriage; I was in Central America on the day that the decision was given, and the homosexual movement in the country I was visiting had a fiesta - as America goes, so goes the world (for good or evil)., ${ }^{31}$

Euteneuer's recognition of the colossal influence of the US indicates the degree to which he sees the rest of the world following the path the US sets. Though HLI makes a great effort to support grassroots movements in developing countries that are aligned with its views, in this text the most important battle for the future of the developing world is still being fought in the US.

James Dobson and Focus also share this sentiment, namely that the innocent in other countries must be protected from the spread of corrupt US culture and politics. In his 'Eleven Arguments Against Same-Sex Marriage,' Dobson warns that 'America continues to be the fountainhead of filth and immorality, and its influence is global. ${ }^{32}$ Like Euteneuer, Dobson sees the US as a global leader in the liberalisation of the moral order. 'If we take this step off a cliff,' continues Dobson with reference to legalising gay marriage, 'the family on every continent will splinter at an accelerated rate.' 33 US-lead globalization, for 'pro-family' organisations, is synonymous with the spread of liberal culture.

\footnotetext{
${ }^{31}$ Euteneuer, T. J. (2003) 'Fighting the Global De-Population Movement,' Human Life International, Humanae Vitae 35th Anniversary Conference, Sydney, Australia, July 25, 2003. Accessed at http://www.hli.org/commentaries_fr_tom_population_ control_fighting_global_pop.html [last accessed 13/11/07].

${ }^{32}$ Dobson, J. C. (2004) 'Eleven Arguments Against Same-Sex Marriage,' Focus on the Family Action, available at http://www.citizenlink.org/FOSI/homosexuality/maf/A000004753.cfm [last accessed 12/08/09]. ${ }^{33}$ Ibid.
} 
Even when 'pro-family' groups are concerned about the role of the US in leading economic globalization, it is because of the impact that economic globalization has in transmitting cultural norms, not because of the effects globalization is having on families in poor countries. In a 2003 text, for example, Euteneuer writes that societies in the developing world are helpless to resist the importation of US culture as they trade with the US:

'The advertising on billboards is all Western wannabees, too. It is sad, not because the West is bad, but because the culture of death and materialism comes with everything we export over there. ${ }^{34}$

Euteneuer clearly sees global trade as connected to the proliferation of a set of values which he opposes, though he is careful not to say that there is anything wrong with the West. The distinction between the propagation of Western exports and advertising (bad) and the West itself (not necessarily bad) appears to hinge on materialism. ${ }^{35}$ In this 'pro-family' depiction of economic globalization, it is impossible for countries which trade with the West to resist the slide towards materialism. In HLI terms, this is a part of the transmission of the 'culture of death,' a term used frequently in HLI texts to describe abortion specifically, and more generally to describe the global spread of values which HLI finds hugely objectionable. For Euteneuer, materialism and 'the culture of death' go hand in hand with globalization.

\section{Globalization as materialism}

Like Euteneuer, most 'pro-family' leaders are concerned with the link between global trade and the values that appear to accompany it. Materialism is a major issue for HLI, and bears much of the blame for declining birth rates in the industrialised world in HLI texts. I return to this subject in chapter six.

In the Religion and Society Report from 2000 cited above, the Howard Center author also sees the material excesses of globalization as a serious problem.

\footnotetext{
${ }^{34}$ Euteneuer, T. J. (2003) 'Pro-Life Missionary Trip: India,' Human Life International, 19 November 2003. Accessed at http://www.hli.org/mission_india_2003.html [last accessed 17/11/06].

${ }^{35}$ Given that the 'culture of death' is something of an intrinsically irredeemable label, akin to 'evil' or 'pro-death', I would argue that the difference here hinges on materialism, the more redeemable term, from which cultural change is at least possible.
} 
'Globalization,' he states, 'is pillage on a planetary scale. ${ }^{, 36}$ Three years later, the same author condemns the 'lust for profit today,' which is 'driving whole nations to the loss of their national identity to the forces of globalization, which certainly profit the few, but not so certainly the many. 37 The warning is clear: if globalization is harmful, people need to be protected from it. It is not clear whether the authors see US corporations as the 'few' behind this 'planetary pillage;' the forces of globalization remain obscure.

In addition to this concern for the 'many,' who presumably come from all over the world, there is a strong sense here that economic nationalism is at work as well. Like the author above, conservative icon Paul Weyrich is concerned that the benefits of globalization are not worth the costs. In his 2005 series on 'The Next Conservatism,' published - though not endorsed - by CWA, Weyrich suggests that it is more important to keep manufacturing jobs in the US than it is to increase economic efficiency through free trade. Moving away from a service economy is desirable, Weyrich suggests, because it would enable average Americans to survive on one income, so that 'mom can stay home and take care of the kids.' 'Life is not just about getting more stuff,' he recommends, and would like to 'restore thrift [rather than consumption] as a virtue' in US conservative culture. ${ }^{38}$ Weyrich, like Carlson and his Howard Center colleagues, would rein in multinational corporations which, in his view, care little about the future of the US. ${ }^{39}$

Although it appears on CWA's website, Weyrich's approach to this topic differs starkly from Crouse's approach to globalization. In her 2006 critique of the United Methodist study described above, Crouse derisively notes that:

\footnotetext{
${ }^{36}$ The Howard Center (2000) 'In Addition to Which,' The Religion and Society Report vol. 17, no. 1, January 2000. Available at http://www.profam.org/pub/rs/rs 1701.htm?search=Islamic\%20family\&opt=ALL [last accessed 12/08/09].

37 The Howard Center (2003) 'Dangerous Virtues,' The Religion and Society Report, vol. 20, no. 7/8, August 2003. See http://www.profam.org/pub/rs/rs_2007.htm?search=globalization\&opt=EXACT [last accessed 12/08/09].

${ }^{38}$ Weyrich, P. M. (2005) 'The Next Conservatism: The Next Conservative Economics,' Concerned Women for America, September 7, 2005. Available at http://www.cwfa.org/articles/8904/CWA/misc/index.htm [last accessed 11/08/09].

${ }^{39}$ Ibid.
} 
'The study suggests that the key to solving the problems of globalization is to buy from artisans, shop at locally owned businesses, buy only fair-trade coffee, and wear only sweat-free-label clothing. ${ }^{40}$

Crouse seems unable to stomach this attitude, labelling this kind of approach as 'demagoguery.' Her response suggests that she sees these as hackneyed solutions to a problem that is bigger than the authors of the study admit. She ends her article sarcastically, parodying the study's recommendations: 'if everyone would just quit drinking bottled water, the word would be a better place and we could end poverty and injustice. ${ }^{41}$ Though she appears to accept that there is a problem with globalization, Crouse has a strong aversion to what she characterises as ineffectual solutions offered by left-wing religious people. Crouse may have moved on from seeing globalization as synonymous with globalism, but the phenomenon is still identified in terms of how it helps her opponents advance their causes. To put it another way, globalization is still a part of the Left's arsenal in CWA's view.

Unlike HLI and CWA, who tend to depict globalization as an exogenous inevitability, the Howard Center does not accept that the way the world economic system is changing is a given. Another option - though not one without drawbacks of its own - exists:

"The only alternative to this "globalization" is a measure of economic protectionism, and of course economic protectionism violates the great canon of globalization and cuts the profits of those most interested. ${ }^{42}$

This Howard Center author prefers barriers to trade to economic globalization, eschewing even a rhetorical commitment to development via free trade. That economic protectionism creates profits for other domestic parties and can disadvantage the poor outside the US does not concern the author; what is important is that impediments to free trade slow or prevent the advance of globalization.

\footnotetext{
${ }^{40}$ Crouse, J. S. (2006) 'The Big G - Globalization: Demagoguery about “America's Economic Exploitation",' Concerned Women for America, August 16, 2006. Available at http://www.cwfa.org/articledisplay.asp?id=11328\&department=BLI\&categoryid=nation [last accessed 12/08/09].

${ }^{41}$ Ibid.

42 The Howard Center (2003) 'The Hidden Violence of Globalization,' The Religion and Society Report, vol. 20, no. 4, April 2003. Available at http://www.profam.org/pub/rs/rs 2004.htm?search=globalization\&opt=EXACT [last accessed 12/08/09].
} 
Again, the Howard Center opposes globalization as a process, and uses justifications that hark back to traditional US isolationism to support its position.

While all the groups reject globalization in a general sense, and take particular issue with the centralisation of power and any corresponding standardisation of culture, the groups themselves do seek to influence global norms. Thus the 'pro-family' objection to globalization is better understood as a reaction against particular aspects of the process that the organisations find offensive or threatening. The following section discusses these aspects.

\section{Globalization and the 'culture of death'}

Those behind the purported 'attack on the family' are characterised with different degrees of specificity by 'pro-family' organisations. HLI refers to its enemy as the 'culture of death,' 'anti-life,' and 'population controllers,' while the other groups tend to prefer slightly different terms such as 'radical feminists/NGOs,' and the 'radical Left,' among others. The majority of these texts stress the global reach of 'anti-family forces.' Thus globalization is both blamed for expanding the reach and influence of the 'culture of death,' and used as a justification for the expansion of 'pro-family' activities beyond the US. Consider the following excerpt from an HLI Special Report:

'...the anti lifers simply cannot leave people alone to just live their lives as they wish. The population controllers and other anti-lifers are fanatic meddlers who are absolutely driven to impose their will upon every human being on earth. ${ }^{43}$

HLI sees itself as struggling against a powerful, technologically advanced, obsessively driven opponent. The report goes on to claim that 'anti-lifers' have 'travelled to the most remote villages imaginable' to disseminate their 'warped gospel of sterility and biophobia., ${ }^{44}$ In this way, HLI places itself in defence of life and traditional culture, on a global scale. This theme is repeated time and again in HLI texts, with the group stressing the need for people to 'understand the

\footnotetext{
${ }^{43}$ Human Life International (2006) Special Report, no. 259, July 2006, p. 1 (Emphasis in original). See http://www.hli.org/sr_july_06.pdf [accessed 13/11/06].

${ }^{44}$ Ibid. This is a complaint frequently aired by HLI. See also Meaney, J. (2003) 'Pro-Life Missionary

Trip: Malaysia,' Human Life International, 13 November 2003, at http://www.hli.org/mission_malaysia_2003.html [last accessed 17/11/06].
} 
worldwide assault of the culture of death against God and man. ${ }^{45}$ Euteneuer gets more specific when he names 'abortion revolutionary groups like International Planned Parenthood Federation, Marie Stopes International, IPAS and other feminist and homosexual non-governmental organisations' as the force behind this assault. ${ }^{46} \mathrm{He}$ contends that these groups "wield millions of dollars and exist for the singular purpose of pushing their own hedonistic agendas on the rest of the world. ${ }^{47}$ For HLI, it is the relatively newfound global abilities and influence of progressive NGOs that are the major problem with globalization, and it is they who are fuelling the 'culture of death.'

HLI makes much of the infringement of national sovereignty by international NGOs, maintaining that these groups press for laws that will both undermine the will of the populace and further their own self-interest and funding base. The group sees progressive NGOs as using their global reach to force their ideologies on unwilling populations, bypassing national boundaries.

HLI authors are particularly interested in protecting developing countries against 'new' and 'radical' ideologies. Many poor countries' experience of globalization is deeply destabilising. The Philippines, for example, is the site of a number of battlefronts for 'pro-family' organisations, and a country HLI sees as something of a bellwether for the 'culture of death.' Seeking a global agent to blame for the cultural and family upheaval of this country, HLI points its finger at NGOs. In an account of an attempt to pass a Bill intended to guarantee universal access to reproductive health services in the Philippines, HLI's Brian Clowes is disturbed to report that:

'One of the most frightening provisions of HB 3773 is that, if it is enacted, the population program would not even be run by the Philippine government.

\footnotetext{
${ }^{45}$ Human Life International (2005) 'Training the Troops: Seminarian Summer Institute,' Human Life International, Human Life International Front Lines, Fall/Winter 2005, p. 7. http://www.hli.org/front_lines_fall_winter_2005.pdf [last accessed 17/10/06].

${ }^{46}$ This is not an acronym. Ipas is 'an international organisation that works around the world to increase women's ability to exercise their sexual and reproductive rights, and to reduce abortionrelated deaths and injuries.' See http://www.ipas.org/ for more details. [last accessed 21/2/08]. Euteneuer, T. J. (2003) 'Fighting the Global De-Population Movement,' Human Life International, Humanae Vitae 35th Anniversary Conference, Sydney, Australia, July 25, 2003. Accessed at http://www.hli.org/commentaries_fr_tom_population_control_fighting_global_pop.html [last accessed 13/11/07].

${ }^{47}$ Ibid.
} 
Instead, it would be operated by a bureaucracy overseen by three non-elected officials from non-governmental organizations like International Planned Parenthood Federation or Family Health International. ${ }^{48}$

HLI's objection in this case is thus wholly against progressive NGOs, who they see as foisting their 'polluted influence' on an innocent populace. ${ }^{49}$ That progressive NGOs have, in HLI's view, come to be responsible for the troubles faced by Filipino families speaks to the desire of 'pro-family' groups to find culprits other than the process of global economic integration to blame for the negative effects of globalization.

It is, of course, highly unlikely that HLI would look favourably on the same Bill even if it were planned and implemented by the sovereign government. In such cases, government decisions that run counter to HLI's value set tend to inspire accusations of official corruption. Consider the following excerpt from Euteneuer's trip to Venezuela:

'[the forces of darkness] lurk in the background until they gain enough political power to impose their will on the population, which remains pro-life despite the corruption of its government officials, judges, intelligentsia, medical profession and media. $^{50}$

It is not so much that the policies are encouraged or imposed by an external agent that is problematic for HLI, it is the nature of the policies themselves. When laws are the result of an elected government, and formed with domestic legal, academic and medical involvement, as in this Venezuelan case, and HLI still argues that they are forced on an unwilling public by corrupt elites, we can be fairly certain that at the heart of the matter, HLI's complaint is not about national sovereignty. As Euteneuer puts it: 'Anywhere the anti-life mentality takes root is mission territory. ${ }^{51}$ In HLI's view, globalization may facilitate the spread of 'the anti-life mentality,' but it is progressive agents that are to blame for the problems that accompany it.

\footnotetext{
${ }^{48}$ Human Life International (2006) Special Report, no. 259, July 2006, p. 1 (Emphasis in original). See http://www.hli.org/sr_july_06.pdf [13/11/06].

${ }^{49}$ Ibid, p. 3.

${ }^{50}$ Euteneuer, T. J. (2004) 'Pro-Life Missionary Trip: Venezuela,' Human Life International, 30 June, 2004. See http://www.hli.org/mission_venezuela 2004.html [last accessed 21/12/06].

${ }^{51}$ Euteneuer, T. J. (2002) 'Pro-Life Missionary Trip: Kenya,' Human Life International, 8 September 2002. See http://www.hli.org/mission_kenya_2002.html [last accessed 17/11/06].
} 


\section{Globalization as secularism}

To put it another way, though HLI may appeal to notions of national sovereignty, their grievance is with any efforts to alter society in a way in which the organisation does not approve, from inside or out. UN resolutions are always a problem for HLI, for example, because they are unmistakeably secular and thus an aspect of the 'culture of death.' Thus HLI sees it as imperative that Christian conservatives react to fight the global spread of secular organisations and their ideologies.

One way HLI has reacted against the diffusion of secular values is to appeal to what it sees as the natural, hard-wired, 'pro-family' principles of people in the developing world. Thus although official channels may be 'corrupted', as in the Venezuelan and Filipino examples above, all is not lost, because HLI sees its values as being aligned with the 'natural' values of people all over the world. 'Nature' will eventually win the day. The following quote on the implementation of comprehensive sex education in Malawi demonstrates:

'What gives me hope is that most teachers are RELUCTANT to teach their pupils this new value-free sex education. There is still shame in the eyes of most teachers.

What they are asked to do contradicts their embedded authentic cultural values.' $^{52}$

This HLI author believes that his organisation must only re-ignite the innate values of people in developing countries to fight off the global onslaught of secularism. HLI's own values are characterised as natural and authentic: those of progressive NGOs are juxtaposed as amoral, bizarre and alien. The same HLI report again takes the side of 'traditional values' over all others, stating that the cultural morality that progressive groups seek to jettison in Malawi 'were always upheld by the entire society. ${ }^{53}$ Putting the factual status of this assertion aside, the permanence and universalism of these values that HLI alleges are worth noting. Such a stance is not only in opposition to globalization, which is seen as an outside force that can only damage the moral cohesion of society, but hides the possibility that some "tradition values' may themselves be different to those held by HLI.

\footnotetext{
${ }^{52}$ Human Life International (2006) Special Report, no. 264, December 2006, p. 3, accessed at http://www.hli.org/sr_dec 06.pdf [accessed 30/01/07]. (Emphasis in original).

${ }^{53}$ Ibid, p. 3.
} 
C-Fam takes a similar stance on tradition, seeing secular NGOs as a threat to 'traditional values.' Responding to a Population Action International (PAI) study on population and development in Africa, C-Fam asserts that '...traditional societal and religious practice vigorously approve of large families, which Africans view as a sign of wealth. PAI calls for eradicating these traditional notions. ${ }^{54}$ Here again we see a secular NGO depicted as a would-be destroyer of traditional and indigenous value. Secularism is contrasted with variety, and portrayed as a force that prevents the acquisition and practice of traditions.

Focus is also concerned that the international realm is growing progressively more secular, or in one author's words, 'our global society has become increasingly more liberal, with a substantial change since the late 1990s. ${ }^{55}$ The article goes on to lament that 'traditional sexual values are disintegrating', leading to the increase of 'many social ills. ${ }^{56}$ Thus a battle is framed on a global scale with tradition, religion and morality on one side and secular liberalism on the other.

In this way, seemingly harmless ideas like women's and children's rights are recognised by 'pro-family' advocates as attacks on the family. Globalization is implicated in this attack. According to a 2008 FRC article, there has been 'an increasing trend against parents' rights,' which 'exists under the guise of globalization and the innocuously-named "children's rights movement.", 57 FRC, like CWA, persists with the idea that there are socialist or 'globalist' actors behind globalization, who seek to infiltrate the family and weaken parents' control of the way that children are raised.

\footnotetext{
${ }^{54}$ Ruse, A. (1998) 'Population Action International Calls for More African Abortions,' Catholic Family and Human Rights Institute, August 28, vol. 1, no. 46. Available at http://www.cfam.org/publications/id.55/pub_detail.asp [last accessed 14/08/09].

${ }^{55}$ Focus on the Family (2008) 'Cause for Concern (Abstinence),' Focus on the Family Issue Analysis, available at http://www.focusonthefamily.com/socialissues/abstinence/abstinence_before_marriage/cause_for_co ncern.aspx [last accessed [14/08/09].

${ }^{56}$ Ibid.

${ }^{57}$ Blackwell, K. (2008) 'Homeschoolers in the crosshairs of the NEA,' Perspective, Family Research Council, March 20, 2008. Available at http://www.frc.org/get.cfm?i=PV08L09 [last accessed 12/08/09].
} 
Taking a slightly different approach, in a lecture on T. S. Eliot, one Family Research Council (FRC) contributor agrees with the famous poet and author that the drift towards secularism is towards 'a life of boredom, alone on a blasted plain.' This, he suggests, is the inevitable result of 'a purely materialistic civilization with all of its technical achievements and its mass amusements. ${ }^{58}$ In the context of capitalist globalization, which hugely increases the number of material things that can be used to amuse oneself, globalization, associated as it is with secularism and materialism in the 'pro-family' vision, is a serious concern for FRC.

It would appear, then, that every 'pro-family' organisation has something negative to say about globalization. Whether it is alarm at the perceived direction of social and economic change, or anxiety about what a future globalized world might be like, all the 'pro-family' organisations take issue with certain aspects of globalization. Are there any aspects that they celebrate?

\section{$\underline{\text { Part II: Globalization as redeemable }}$}

'Pro-family' texts advancing the merits of globalization range between tacit approval of the new abilities of 'pro-family' groups to extend their influence beyond US borders, a grudging commitment to free trade, and a kind of prim approval of globalization purely for the reason that the Left sees it as a problem. No 'pro-family' group explicitly praises globalization; rather they seem to consent to its going on, or see no alternatives to it. The groups are encouraged by the global transmission of 'pro-family' norms and values, the increasing ability to permeate national boundaries and generally approve of international trade as a means to prosperity. This section is organised under five headings, each describing an aspect of globalization of which 'pro-family' organisations appear to appreciate.

\section{Globalization facilitates the widespread proliferation of 'pro-family' values}

Even while criticising its opponents for the violation of national sovereignty in developing countries, HLI is heartily satisfied with its own enhanced ability to interact with people in the farthest corners of the globe. On a 'pro-life mission' to Tanzania, for example, Euteneuer exclaims that he is 'constantly amazed to see

\footnotetext{
${ }^{58}$ Frohnen, B. (2001) 'Witherspoon lecture: T. S. Eliot on the necessity of Christian Culture,' Family Research Council, available at http://www.frc.org/get.cfm?i=WT01A1 [last accessed 15/08/09].
} 
HLI's reach - even to little Zanzibar! ${ }^{59}$ HLI also credits itself with preventing abortions in developing countries: the author of one HLI publication suggests that 'without HLI, many babies in the third world would be killed by agents of the devil. ${ }^{60}$ HLI is able to travel to these remote destinations, influence their officials and report back from them only because of innovations in global communication and transport technology. The reports repeatedly thank the sponsors of HLI for their funds, collected through HLI's donation webpage, which finance 'pro-life missions' to previously inaccessible areas.

HLI's mission reports show that HLI and its partner organisations in developing countries are extremely satisfied with the global network that they have created. In a trip to Paraguay, Euteneuer writes that 'the pro-lifers there are so glad to belong to an international pro-life organization. It gives them a sense of belonging, encouragement and great support in their efforts. ${ }^{61}$ HLI clearly sees itself as invited to act without concern for national boundaries, seeing its actions as justified both by its network in the countries in which it is active and the righteousness of its cause. Indeed, Euteneuer states unambiguously: 'the fight for life is a global one and is not just limited to what happens in one culture or another... ${ }^{62}$ The organisation sees no problem with working in defiance of state authorities. In a trip to Hong Kong, for example, Clowes is pleased to report on the successes of the underground Catholic movement in China. ${ }^{63}$ For HLI, national sovereignty is easily trumped by globalization, when it is HLI with the trump card.

The same can be said of HLI's approach to tradition. As was noted earlier, HLI and C-Fam both enthusiastically offer themselves as the guardians of tradition and 'authentic cultural values.' However, where these values conflict with those of HLI,

\footnotetext{
${ }^{59}$ Euteneuer, T. J. (2002) 'Pro-Life Missionary Trip: Tanzania,' Human Life International, 1 September, 2002. http://www.hli.org/mission_tanzania_2002.html [last accessed 17/11/06].

${ }^{60}$ HLI (2005) 'Tanzania: Aid from HLI Switzerland,' Human Life International's Front Lines, Fall/Winter 2005, p. 5. http://www.hli.org/front_lines_fall_winter_2005.pdf [accessed 17/10/06].

${ }^{61}$ Euteneuer, T. J. (2002) 'Pro-Life Missionary Trip: Paraguay,' Human Life International, 14 June 2002. See http://www.hli.org/mission_paraguay_2002.html [last accessed 21/12/06].

${ }^{62}$ Euteneuer, T. J. (2003) 'Fighting the Global De-Population Movement,' Human Life International, Humanae Vitae 35th Anniversary Conference, Sydney, Australia, July 25, 2003. Accessed at http://www.hli.org/commentaries_fr_tom_population_ control_fighting global_pop.html, [last accessed 13/11/07].

${ }^{63}$ Clowes, B. (2002) 'Pro-Life Missionary Trip: Hong Kong,' Human Life International, October 2002. Accessed at http://www.hli.org/mission_hong_kong_2002.html, [last accessed 17/11/06].
} 
cultural change and progress are heartily welcomed. In a mission trip to Malaysia, for example, Clowes notes that:

'Conversions [to Catholicism] are even more numerous among the different indigenous tribes who had previously practiced various forms of animist religions and who were infamous for such practices as head-hunting and ritual cannibalism. ${ }^{64}$

\section{Similarly, Euteneuer in Costa Rica writes:}

'Catholicism has always taught pagan societies how to form marriages and families because it has always known that these are the primary stabilizing forces of society. ${ }^{65}$

HLI is choosy in the range of cultural values it sees as authentic: ancient practices that do not fit with HLIs values are best relegated to the past. Where the globalization of secular values is seen by HLI as an affront to the cultural values of traditional societies, social change produced by the globalization of Catholicism is seen as valuable and legitimate.

\section{Globalization means the 'spirit-rich' South can evangelise the materialist West}

Another aspect of globalization of which HLI approves is the possibility that people from developing countries can and will 're-evangelise' the West. HLI's Brian Clowes writes that

'A century ago, the West evangelized Africa, and now the young and lively Faith of the Africans is evangelizing the dying West. Isn't it wonderful how the Holy Spirit has everything planned out? We win in the end: I've read The Book. ${ }^{, 66}$

Characterising the West as 'dying' turns development on its head: for HLI, the West is "...the so-called "developed" world (economically but not spiritually developed)...67 As such, HLI sees globalization as providing the means for 'spiritrich' Africa to enlighten and re-orient richer countries towards Christianity, as an inevitable and predictable part of God's divine plan. The 'young and lively' are

\footnotetext{
${ }^{64}$ Meaney, J. (2003) 'Pro-Life Missionary Trip: Malaysia,' Human Life International, 13 November 2003, http://www.hli.org/mission_malaysia_2003.html [17/11/06].

${ }^{65}$ Euteneuer, T. J. (2003) 'Pro-Life Missionary Trip: Costa Rica,' Human Life International, 30 June 2003. http://www.hli.org/mission_coasta_rica_2003.html [last accessed 21/12/06].

${ }^{66}$ Clowes, B., (2004) 'Pro-Life Missionary Trip: Nigeria,' Human Life International, May $25^{\text {th }}$, 2004. See http://www.hli.org/mission_nigeria_2004.html [last accessed 16/11/06].

${ }^{67}$ Euteneuer, T. J. (2003) 'Pro-Life Missionary Trip: Mexico,' Human Life International. 20 January, 2003. See http://www.hli.org/mission_mexico_2003.html [last accessed 21/12/06].
} 
juxtaposed with the West, almost certainly a reference to the 'demographic winter' depicted by 'pro-family' organisations, which is discussed further in chapter six. Euteneuer makes a related comment during his aforementioned trip to the Philippines:

'Fr. Marx used to comment that the Philippines has supplanted Ireland as the world's primary exporter of Catholicism and missionary of Catholic culture through the millions of Filippino [sic] Catholics who take their Faith with them when they leave. $^{68}$

Seeing the diaspora of (usually female) Filipinos and the global promulgation of Catholicism as positive are undoubtedly evidence of HLI's enthusiasm for globalization, albeit of a certain type. This happy disregard for national boundaries even appears to supersede the 'pro-family' concern that the 'export' of Filipino Catholics often leads to the long-term separation of family members. At any rate, while HLI may not explicitly state that globalization is a positive occurrence, it has no staunch loyalty to the ideals of national autonomy or democracy. In terms of ideology, compared to the other organisations examined here, HLI is proglobalization.

3. Globalization gives 'pro-family' organisations a voice in international policymaking

The Howard Center takes a far more cautious approach than HLI, preferring to find international allies and appeal for some semblance of international approval before it takes its values to the people of the developing world. Thus the Howard Center's support for globalization can be understood in terms of the potential top-down propagation of norms that it supports. In Carlson's reaction against the secular standards he sees as implicit in the Children's Convention, he offers his own alternative universal doctrine. He suggests that

'...in place of the current UN "Children's Rights" Convention, we could call on the nations of the world to secure to each child the Rights to a mother, a father, a home built on marriage, siblings, ancestors, posterity, religious faith, a healthy community, innocence, and tradition... These goals are what the governments of the world should

\footnotetext{
${ }^{68}$ Euteneuer, T. J. (2001) 'Pro-Life Missionary Trip: Philippines,' Human Life International. 20 October 2001. See http://www.hli.org/mission_philippines_2001_II.html [last accessed 17/11/06].
} 
seek and a focus on this list of rights would return the United Nations to its original and healthy pro family position. ${ }^{69}$

In this effort, Carlson seeks to universally advance 'pro-family' ideals as the instruments to improve the well-being of children. Rather than state that children have a (direct) right to security, health and material abundance, Carlson offers the divorce-free, fertile, heterosexual marriage as the means to achieving these tangible ends. Carlson's promotion of his set of 'pro-family' global principles is a direct effort to press for global norms of which he and his allies approve. That he finds it consistent with the intentions of the founders of the UN - contrasting it with the hijacking of the UN by his ideological opponents - suggests Carlson sees a role for 'pro-family' advocates in returning the UN to its 'proper' course. I return to this sentiment in the following chapter.

C-Fam is less clear in its advocacy for its own political positions. The documents that can be interpreted as being somewhat in support of globalization are of two types: those that promote universal rights which the group sees as 'pro-family,' and those that support free trade as the means to development. Whilst C-Fam presents a general impression of aversion to new applications of UN human rights documents as a matter of principle, the organisation is aware of the footholds it may gain as these documents are renegotiated and applied, as in the following 2006 example:

'Conservatives are disappointed, however, that the new [UN] resolution excludes the protection of children before birth, despite the fact that the Convention on the Rights of the Child (CRC) explicitly states: "Whereas the child, by reason of his physical and mental immaturity, needs special safeguards and care, including appropriate legal protection, before as well as after birth.",70

C-Fam's intention is to protect the unborn on a global scale. Thus it is clear that whether C-Fam prefers the world to be organised into self-governing nations or morphed into a global village, it has decided to press for its political and social goals in the most influential global forum available, the UN General Assembly. It

\footnotetext{
${ }^{69}$ Carlson, A. (2002) “"The Family” at the United Nations: What Went Wrong? And How To Get It Right Again. Remarks to the seminar on the U.N. Convention on The Rights of the Child,' The Howard Center, Awakenings Conference, The Cloister, Sea Island, Georgia, 4-6 January, 2002. http://www.profam.org/docs/acc/thc_acc_cloister020104.htm [last accessed 16/08/09].

${ }^{70}$ C-Fam (2006) 'Violence Against Women and Children Resolutions Still Outstanding at UN Third Committee,' Catholic Family and Human Rights Institute Friday Fax, vol. 9, no. 49, November 23, 2006. Available at http://www.c-fam.org/publications/id.489/pub_detail.asp [last accessed 17/08/09].
} 
could be argued that the organisation, taking globalization as a given, is simply defending or promoting the 'pro-family' way of life. However, I suggest that CFam is using globalization as an opportunity to promote its policies on a global scale. Indeed what may have begun as a defensive effort may now have evolved into a global offensive. In its discussion of a then upcoming WCF, C-Fam writes that its organisers intend to "craft a declaration and platform of action to serve as guides to family protection and renewal around the globe. ${ }^{71}$ As pro-active as the effort to create a new declaration appears however, the organisers still frame their efforts in antagonistic terms. If C-Fam (and indeed all the groups) can be said to be promoting globalization of a kind, its characterisations are not sketched in any positive substance, but simply defined in terms of what it is not: not 'anti-family,' and not 'population "bomb" ideology.'

\section{Economic globalization is the means to prosperity}

Similarly, while C-Fam texts do tend to promote economic globalization as the most appropriate path to development, their arguments tend to be framed in opposition to their adversaries rather than in favour of the freedom or prosperity that free trade may bring. C-Fam expressed support for open markets in 1999, positioning itself with the developing world, against the Clinton Administration and the EU:

'The real breakdown came with the call for free trade and open markets. This is a priority of the developing world and one looked upon generally favorably by the west. In this instance, however, the US and EU flatly refused to negotiate on this point. $^{72}$

During the Bush Administration, however, C-Fam's texts promoting free trade as a means of development tended not to mention the US government directly.

In 2005, C-Fam supported the following Heritage Foundation document which promoted 'economic freedom':

\footnotetext{
${ }^{71}$ C-Fam (2004) 'Mexico City Conference to Highlight Role of Family in Development,' Catholic Family and Human Rights Institute Friday Fax, vol. 7, no. 7, February 6, 2004. Available at http://www.c-fam.org/publications/id.342/pub_detail.asp [last accessed 17/08/09].

${ }^{72}$ C-Fam (1999) 'First Prepcom for Copenhagen+5 Ends in Stalemate at UN Headquarters,' Catholic Family and Human Rights Institute Friday Fax, vol. 2, no. 31, June 4, 1999. Available at http://www.c-fam.org/publications/id.94/pub_detail.asp [last accessed 17/08/09].
} 
'The document stresses that developing countries need more than international aid to end poverty. It declares that "economic freedom, good governance and the rule of law" are necessary for economic growth and that appropriate emphasis must be placed on the role of the private sector. "Development will not occur unless developing and developed countries alike open their markets and encourage private investment and entrepreneurship.",73

C-Fam's endorsement suggests that the organisation is comfortable with the idea of economic globalization as a means to development. Whether 'good governance' and 'the rule of law' in this quote are intended only in the domestic realm, or may also apply to international regulatory bodies, is uncertain. While free markets still largely remain a key rhetorical tool in 'pro-family' discussions about development, there are very few 'pro-family' texts that openly discuss the capitalist aspects of globalization. Bringing support for increased global trade (and corporations) together with the idealised 'pro-family' society is a task that has been left largely unaddressed in 'pro-family' texts.

\section{Our enemy's enemy must be our friend: globalization is better than what the} Left wants

As has already been discussed, CWA advocates on the side of freeing up international trade as the most important means to prosperity. CWA's stance is firmly against international regulation, which Crouse and her colleagues frame as an attempt to bring about a world government. While CWA does suggest that 'value-based investing' - in which conservative Christian shareholders invest in companies that fit 'pro-family' criteria - is a suitable response to what the group deems a moral crisis within American capitalism, the organisation does not make the same suggestions when it comes to the problems associated with global capitalism. ${ }^{74}$ It seems likely that Crouse in particular, and CWA in general, are torn between anxiety about the effects of globalization on the US populace and a deep dislike of all of the solutions offered. Unsurprisingly, CWA struggles to balance its

\footnotetext{
${ }^{73}$ C-Fam (2005) 'Conservative Document Endorsed by 700 NGOs Presented to UN Today,' Catholic Family and Human Rights Institute Friday Fax, vol. 8, no. 38, September 9, 2005. Available at http://www.c-fam.org/publications/id.424/pub_detail.asp [last accessed 17/08/09].

${ }^{74}$ Kleder, M. (2003) 'Values-Based Investing: A Tool for Pro-Family Activists,' Concerned Women for America, 21 January, 2003. http://www.cwfa.org/articledisplay.asp?id=3107\&department=CFI\&categoryid=papers [last accessed 17/08/09].
} 
allegiance to free enterprise and fairness and its commitment to US national sovereignty. Crouse's study of the National Council of Churches study on the Millennium Development Goals (MDGs) concludes that:

'... the NCC is saying that the United Nations, not Jesus Christ, is the salvation of the world. The NCC is surrendering leadership to a secular entity and offering utopian solutions, instead of Biblical ones, to the world's problems. To add insult to injury, the NCC is using its member churches as foot soldiers to carry forward the UN agenda around the world. ${ }^{75}$

Opposing church support of the UN here overrides any concern that Crouse may have with the material benefits to families in poor countries that might be achieved with widespread support of the MDGs. Like C-Fam, CWA's approach to globalization remains, for the most part, reactionary.

Increasingly, however, CWA has enlisted in more activist 'pro-family' global initiatives, notably the WCF. Crouse has been a plenary speaker at these events and writes that the (then upcoming) conference in Poland

'will bring together an international network of leaders who work to strengthen the family around the world. Not surprisingly, many of the problems facing the family here in the US are also problems in other countries. As we network together, each of us is strengthened in our work in our own nation. Having WCF IV in Poland makes a strong statement to other European nations about the world-wide support for pro-life, pro-marriage and pro-family policies. ${ }^{, 76}$

Like the other organisations studied here then, CWA perceives the advantages in creating a 'pro-family' global network to actively press for their policies. Claiming world-wide support for its political views, CWA is repeating Carlson's assertion that 'pro-family' organisations have the backing of the majority of the world's people. Though the emphasis is on taking the experiences gained at the international

\footnotetext{
${ }^{75}$ Crouse, J. S. (2006) 'Misguided Attempts to Eradicate Global Poverty: An analysis of the National Council of Churches Study Guide on the Millennium Development Goals,' Concerned Women for America, 15 August 2006. Available at http://www.cwfa.org/articledisplay.asp?id=11307\&department=BLI\&categoryid=reports [last accessed 17/08/09].

${ }^{76}$ CWA (2007) 'CWA Joins Press Conference Announcing Largest Gathering of Pro-Family Leaders,' 16 March, 2007, Concerned Women for America, http://www.cwfa.org/articles/12592/MEDIA/family/index.htm [last accessed 17/08/09].
} 
level back to strengthen 'our work in our own nation,' the Congress is also intended as a strong statement to opponents of the 'pro-family' view.

\section{Part III: Tensions}

This chapter has shown that although 'pro-family' organisations define globalization in mostly negative terms, they are actively promoting a set of "profamily' positions with which they intend to influence debates on development and human rights well into the future. The 'pro-family' groups studied here are increasingly behaving like progressive NGOs in their attempts to form global "profamily' networks and gain the support of like-minded delegates from developing countries. They are undeniably globalizing their activism, even as they claim to oppose globalization.

Many 'pro-family' advocates still see the role of international 'pro-family' organisations as defending the world from the onslaught of secular global forces. In this way, 'pro-family' activists see themselves not as proponents of their own ideological views, rather they are simply representing the 'normal' view in contrast with those of their 'radical' opponents. In the chaos of globalization and the ascendancy of liberalism, 'pro-family' advocates suggest that people have lost their bearings about what is right and what is wrong, and it is the job of the 'pro-family' movement to point the way.

Characterisations of globalization as culture-less, value-less and confusing has considerable currency for 'pro-family' activists. These organisations portray themselves as resisting a kind of social nihilism that threatens variety and freedom and only values profit and gratification. Yet this leads 'pro-family' opponents of globalization towards unification of purpose with the political Left, who have a parallel antipathy to the profit-driven and culturally destructive direction of economic globalization. CWA avoids discussing issues around which it shares a position with its archrivals, except to criticize their opponents' positions whilst keeping their own obscure. HLI's yardstick is abortion (and to a lesser extent, contraception and sex education), and whilst other issues arise in their texts, the organisation's stance on globalization depends entirely on whether it contributes to or opposes 'the culture of death.' C-Fam chooses its fights more carefully than HLI, 
hiding any approval of 'pro-family' globalization behind its critical approach. Yet in this, C-Fam has the same problem as CWA: its condemnation of its enemies only partially conceals its deep ambiguity about what globalization means and what to do about it. Focus and FRC, for their parts, have very little to say about globalization except that it can be equated with the spread of secularism and the breakdown of national boundaries across the world. Yet, more than any of the other groups, Focus on the Family wields significant influence beyond the US through its chapters in other countries. This must be taken into account when considering that organisation's view of globalization.

Of the groups under scrutiny here, only the Howard Center has considered the meaning of globalization in any depth. This organisation prefers not to embrace aspects of global capitalism which it sees as potentially detrimental to family structures, and has chosen to enter into a meaningful discussion about the dangers that new global power structures hold for freedom the world over. It is also wary of the sacrifice that any truly representative global democracy would demand of US hegemony. For these reasons, the WCF (which is organised by the Howard Center) could be seen as a global effort to resist certain aspects of globalization. I would suggest, however, that the Howard Center's foray into the global arena since the first WCF in 1999 is more ambitious than this, reflecting an increasingly ardent desire to win the world over with the persuasive power of 'pro-family' arguments. The WCF and Carlson's "natural family manifesto ${ }^{, 77}$ is evidence of the desire to combat secular globalization in a broad sense. The manifesto is a platform for an inter-faith, conservative alliance which is intended to advance an alternative future for the world: 'a world restored,' in Carlson's words. ${ }^{78}$

HLI, at the other end of the scale, sees the problems with globalization as being entirely related to global agents propagating values and practices HLI abhors. As much as HLI resents the global achievements of feminist NGOs, the organisation unreservedly uses and values that same potential for its own purposes. For this

\footnotetext{
${ }^{77}$ Available through www.profam.org [last accessed 29/09/09].

${ }^{78}$ Carlson, A. (2005) 'Beyond the Culture War: On the Natural Family: A Manifesto,' Concerned Citizens for America town hall meeting, 20 October 2005, Central Christian Church, Rockford, Illinois, available at http://www.profam.org/docs/acc/thc.acc.cca.051020.htm [last accessed 07/09/09].
} 
group, the structure or system driving globalization is not of particular concern. Indeed HLI seems almost uninterested in the workings of international institutions, capitalism and information technology, instead choosing to focus its disapproval on NGOs and occasionally national governments which support access to reproductive health services.

CWA stands out as the least able to come to a clear position on globalization either from a structural perspective or in terms of the agents involved in the phenomenon. Its authors are clearly divided between the threat of growing social instability that they see as inherent in the process of globalization, and a rejection of regulatory bodies other than the nation-state that might be put forward to alleviate this instability. CWA plainly has the strongest rhetorical commitment to open markets and entrepreneurship as the path to progress. Yet this standpoint clashes strongly with its firmly pro-US stance, evident even in the name of the organisation. Thus the most we can say for this organisation is that insofar as globalization is interpreted as being synonymous with decreasing US control - and the relative rise of UN influence - CWA is opposed to the process. However, CWA is involved in a number of international campaigns on issues that it sees as being of global importance. One of these is the effort to end human trafficking and prostitution, which CWA would argue is a necessarily global response to a problem that is caused or exacerbated by globalization. CWA also strongly supported an abandoned US-introduced resolution at the UN condemning sex-selected abortions, which would have effectively forced countries to change their domestic laws by UN fiat. Again we see the same pattern: like all other 'pro-family' organisations, CWA discourse combines rhetorical anti-globalization with vigorous global activism and claims to universal moral authority.

\section{Conclusion}

Of the three characterisations described in the introduction to this chapter, the 'profamily' picture of globalization most fits McMichael's approach, in which globalization is seen as a political project undertaken by a set of elites unsympathetic to the needs of society (as 'pro-family' organisations define those needs). This is sometimes because the groups see rising economic inequality and instability as a problem in itself, but more often it is because the organisations pit 
themselves against globally active 'anti-family' elites, be they corporations, governments or international institutions. In this way, the 'pro-family' approach to globalization can be understood in much the same way as other counterglobalization movements: they condemn the disappearance of local industry, they abhor the idea of global central planning, and they are deeply concerned about the normative changes wrought by globalization all over the world. In 2004, Carolyn Gallaher summed up a common perception about how 'the Religious Right Reacts to Globalization,' writing that

'Religious Right leaders have responded to globalization by invoking nationalist rhetoric, over time consolidating their position under the discursive umbrella of national sovereignty and calls for its protection. ${ }^{, 79}$

Though this is broadly true of many in the Christian Right, this chapter has shown that 'pro-family' leaders are struggling to maintain this stance. This is because of a number of broadly held ideological commitments. This tendency towards isolationism clashes markedly with 'pro-family' global activism. Economically speaking, the rhetorical importance of open markets and deregulation over aid is a key aspect to the way 'pro-family' organisations believe development should occur. Uncertainty about whether or how to criticise US corporations for their role in globalization pervades the few texts in which the author is willing to broach the subject. Perhaps most importantly, in accepting the invitation by Bush to influence and represent US positions on development and human rights, 'pro-family' organisations can no longer remain wholly critical of international cooperation, the growing global influence of civil society, or the global broadcasting of norms and ideas.

Time and again 'pro-family' groups show that they both dislike globalization and welcome it at the same time. Each group has its own take on what globalization is, and each has its own set of issues that motivate its global activism. And, as noted previously, all these groups are enthusiastically active at the global level. Yet the overwhelming majority of 'pro-family' discourse is in opposition to globalization, however it is defined. I would argue that there are two ways to understand this

\footnotetext{
${ }^{79}$ Gallaher, C. (2004) 'The Religious Right Reacts to Globalization,' in Tétrault, M. A. and R. A. Denemark (eds.) Gods, Guns and Globalization: Religious Radicalism and International Political Economy, International Political Economy Yearbook, vol. 13 (London: Lynne Rienner), p. 31.
} 
discord. The first is to see 'pro-family' global activism as evidence that the groups accept that social norms must now be contested at the global level. Though they would prefer to maintain national sovereignty and fight for their policies in the domestic arena, they feel that they can only defend their way of life by mounting a full-scale global offensive. This perspective characterises the way 'pro-family' organisations presented their activities in the early stages of their global emergence, and lingers in the discourse of CWA in particular, and C-Fam, to a lesser degree. Global activism, in this sense, is a reluctantly embraced defensive strategy.

The second way of understanding this is that 'pro-family' activism is actually better suited to the global sphere than the US. Globally, 'pro-family' organisations may be freer to advance their views than they are in the US domestic sphere. Nevertheless, for 'pro-family' groups to continue to promote their global agenda, they will have to either change the way they talk about globalization, or mute their criticisms of it, as we have seen in the case of the Howard Center.

In terms of understanding this change, we can revisit Peter Beyer's contention that globalization wears away older identities and encourages the creation of new ones, in order to gain control over power in the global system. ${ }^{80}$ In the confusion of "profamily' discourse on globalization depicted in this chapter, we can see that globalization is indeed eating away at aspects of older Christian Right politics. Opposition to rival religions is softening, as is the 'pro-family' stance on development. A new, Global South-friendly 'pro-family' politics is emerging that places the families of all countries ahead of more local political issues. Thus the older 'pro-family' identity is being replaced by a globally ambitious movement that appeals to many different kinds of social conservatives. In time, we may see the 'pro-family' movement rearranging its priorities even further, to better facilitate the inclusion of more and more conservatives from all over the world. But this process is a messy one. It requires considerable ideological flexibility and the recasting of old enemies - and allegiances - in new roles. Over time, however, if this movement is successful, it will bring 'pro-family' organisations together into a global network with shared aspirations that extend far beyond the US political scene. As we are just

\footnotetext{
${ }^{80}$ Beyer, P. (1994) Religion and Globalization (London: Sage), p. 3.
} 
beginning to see, the 'pro-family' movement is acting on a profound desire to reshape the way people all over the world think about their lives, their families and the role of religion in society. With this in mind, the following chapters show the ways in which three old global enemies, the UN, feminism, and population control, are being reframed in 'pro-family' thought. 


\section{Chapter Four: The United Nations in 'pro-family' thought}

'Nationhood as we know it will be obsolete [and] all states will recognise a single, global authority.'

Strobe Talbott, quoted by Concerned Women for America, 1998. ${ }^{1}$

'The family is the natural and fundamental group unit of society and is entitled to protection by society and the state.'

Allan Carlson quotes the UN Declaration of Human Rights ${ }^{2}$

The UN looms large in the 'pro-family' view of the global realm. Originally seen by Christian Right activists as an institution too weak to 'stand up' to communism, after the Cold War, the UN came to embody a communist threat in itself. Perceptions of the institution are still changing, with 'pro-family' leaders now investing time and energy into the UN system as they seek to 'return' the UN to its 'proper' 'pro-family' role. To understand the changing role of the UN in 'profamily' thought, I briefly sketch the history of Christian Right approaches to the institution before describing how academics have interpreted the 'pro-family' agenda at the UN.

Since its inception, the UN has been tainted by its association with communism in US Christian Right thought. This is both because it has contained communist states, and because of its own non-religious character and allegedly totalitarian ambitions. ${ }^{3}$ In the view of early Christian Right activists, the UN has always lacked the religious foundations that would make it a strong and legitimate force for good in international affairs. The 'failure' of the UN to criticise Russia and China during the Cold War confirmed Christian Right suspicions that it was in the service of

\footnotetext{
${ }^{1}$ CWA (1998) 'The United Nations,' Concerned Women for America, 15 April, 1998. Available at http://www.cwfa.org/articles/1852/CWA/nation/index.htm [last accessed 24/08/09].

${ }^{2}$ See http://www.profam.org in general. (Articles published in 2000, 2002, 2004, 2005).

${ }^{3}$ Discussing why the UN did not 'stand up to Russia' during the Korean war, Billy Graham reported that 'At the first meeting of the United Nations in San Francisco, there was no prayer made to God for guidance and blessing. We were afraid that the Godless, atheistic communists would not like it, so we bowed in deference to Russia.' Martin, W. (1996) With God on our side: the rise of the religious right in America (New York: Broadway Books), p. 35.
} 
communism. Some Christian anticommunists denounced the institution, with Barry Goldwater calling on the US government to pull out of the UN. ${ }^{4}$

During the Cold War, this view merged with Christian Right apocalyptic beliefs in the minds of some Christian Right leaders. Pat Robertson, for example, saw the UN as an agent of a satanic conspiracy 'to bring about a godless, socialist one world government. ${ }^{5}$ More temperate conservative Christian activists still called on their government to take action against the UN's acquiescence to communism, with William F. Buckley calling on then-president Nixon to stop the US delegate from voting in the General Assembly because of its acceptance of the People's Republic of China in 1971. ${ }^{6}$ Nixon did not, leaving Buckley to despair that the US had 'lost irretrievably - any remaining sense of moral mission to the world. ${ }^{7}$

By the end of the Cold War, Christian Right attitudes to the UN began to change, with the UN depicted as a rising global power. Conservatives expressed their concern that their leaders, both Democrat and Republican, were in thrall to the UN. ${ }^{8}$ This sentiment increased over Clinton's presidency, with Christian Right leaders alarmed at the speed with which cooperation between their government and the UN made headway promoting policies they strongly opposed. Seeking to bring this to a halt, 'pro-family' organisations began to attend UN meetings (as discussed earlier), which marked the beginning of organised Christian Right opposition to the UN. As Butler notes, 'pro-family' leaders were alarmed by the conferences both because of the inclusion of sexual and reproductive rights language, and because 'liberal activists were successfully advancing their agenda through such bodies and exporting that agenda to other parts of the world. ${ }^{9}$

\footnotetext{
${ }^{4}$ Barry Goldwater called on the US government to withdraw from the UN. Ibid, p. 80.

${ }^{5}$ Shriver, P. (1999) 'Table Manners: Sitting around the Public Table,' in Swatos, W. H. and J. K. Wellman (eds.) The Power of Religious Publics: Staking Claims in American Society (Westport: Greenwood Publishing Group), p. 89.

${ }^{6}$ Diamond, S. (1995) Roads to Dominion: Right-wing movements and political power in the United States (New York: the Guilford Press), p. 120.

${ }^{7}$ Ibid.

${ }^{8}$ In his 'America First' campaign, Pat Buchanan accused George Bush of being 'an Ivy League globalist wedded to such institutions as the UN and the World Bank, when we Americans have got to start looking out for America first.' Ibid, p. 293.

${ }^{9}$ Butler, J. S. (2006) Born Again: The Christian Right Globalised, Pluto Press, p. 15.
} 
The 'pro-family' presence at UN conferences grew from this time, and included neo-conservative organisations as part of a broader alliance intended to direct the work of the UN towards conservative goals. Butler quotes a Heritage Foundation document from 2001 which justified its association with the UN by stating that its "presence will break the "Liberals only" roster of present NGOs. 10

Some 'pro-family' organisations still advocated that the US should not be involved with the UN, despite their own association with it. In a 1999 interview with Buss and Herman, for example, Sheila Moloney of Eagle Forum stated that her organisation believed that the US 'should completely get out of the UN.' ${ }^{11}$ In spite of this sentiment, Eagle Forum had already sought and been granted Special Consultative Status at the UN in $1998 .^{12}$

The UN still embodies a socialist/communist threat in 'pro-family' thought in the post-Cold War context because it is seen as 'big government' writ large. As Buss and Herman put it, the UN is 'a force for the international centralisation of power. ${ }^{13}$ The UN is seen as dangerous not only because its conferences have the potential to change domestic law and public policy, but also because it represents to 'pro-family' organisations the growing threat of enormous institutional power outside of the US. One Christian Right organisation, for example, condemns 'the astounding international takeover of the control of children. ${ }^{14}$ Combined with this suspicion of the UN, however, is a growing acknowledgement that NGO status at the UN is a source of legitimacy for 'pro-family' organisations. In turn, their involvement legitimises the UN to their 'pro-family' base, making the relationship a dynamic and complicated one. With these conflicting approaches and history of hostility, how can we best understand the 'pro-family' agenda at the UN?

Academics are divided as to how to understand 'pro-family' intentions when it comes to their activism at the UN. Stuart Croft argues that the Christian Right is

\footnotetext{
${ }^{10}$ Ibid, p. 50.

${ }^{11}$ Buss, D. and D. Herman (2003) Globalizing Family Values: the Christian Right in International Politics, (Minneapolis: University of Minnesota Press), p. 51.

${ }^{12} \mathrm{See}$ http://www.un.org/esa/coordination/ngo/ for NGOs with consultative status at the UN [last accessed 11/06/08].

${ }^{13}$ Buss and Herman, op. cit., p. 47.

${ }^{14}$ This is the John Birch Society. See Herman, op. cit., p. 63.
} 
inherently hostile to the UN. In his analysis, conservative Protestants attempt to manipulate the processes of the UN for the purpose of promoting their social agenda at the global level. ${ }^{15} \mathrm{He}$ acknowledges the number of Christian Right organisations that are active in the UN development arena is now considerable, but argues that this does not necessarily mean that the Christian Right is increasingly supportive of the UN. In Croft's view, the UN is 'merely a tool., 16

By contrast, Buss and Herman characterise 'pro-family' organisations as deeply ambivalent about the UN. Both Croft's and Buss and Herman's examinations of the Christian Right acknowledge the importance of the UN in the worldview of the Christian Right, but arrive at quite different conclusions as to what Christian Right groups want to achieve through their activism in this organisation. In Buss and Herman's view, the UN is depicted in two quite different ways by 'pro-family' organisations. In the first, the UN is a global entity that is attempting to gain control over the countries and people of the world. In Buss and Herman's words, the UN is 'corrupt to its core and implicated in the global consolidation of power. ${ }^{17}$ If this interpretation is correct, it follows that the 'pro-family' agenda at the UN must be understood as highly antagonistic. Their second depiction sees the UN as a forum that has been hijacked by 'anti-family' forces. ${ }^{18}$ In this reading, the role of the 'profamily' movement is to retain the good aspects of the organisation and remove the bad ones. Writing in 2003, Buss and Herman see the movement as still struggling to decide on its role at the UN.

Buss and Herman's more complex understanding of the dynamics affecting the Christian Right and the UN sees tensions and opportunities emerging within the movement because of its activities there. In their analysis 'pro-family' involvement at the UN thus has the potential to change the ideology and agenda of 'pro-family' organisations in a way that Croft's interpretation does not allow.

\footnotetext{
${ }^{15}$ Croft, S. (2007), 'Thy Will be Done: The New Foreign Policy of America's Christian Right,' International Politics, Issue 44, p. 707.

${ }^{16}$ Ibid, p. 703.

${ }^{17}$ Buss and Herman, op. cit., p. 57.

${ }^{18}$ Ibid.
} 
Butler discerns three stages in the activism of Christian Right NGOs at the UN. The first she describes as 'symbolic protest,' in which the organisations' efforts were directed at encouraging conservative countries to demur from consensus with liberal proceedings at the UN. ${ }^{19}$ This stage is closely connected to 'pro-family' justifications of their involvement at the UN as acting as a 'UN watchdog.' The second stage Butler describes is where 'pro-family' groups become 'insiders' in the UN arena, with the help of President Bush. The third is what Butler calls 'a proactive agenda on the issue of family. ${ }^{20} \mathrm{By}$ this final stage, Butler writes, "profamily' groups found themselves in the position of using a UN legal structure they have always opposed to advance policies that they support. ${ }^{21}$

Butler also notes the interest some Christian Right groups have in 'returning' the UN to its 'proper work,' and sides with Buss and Herman's interpretation that 'profamily' organisations see the UN as 'corrupt but salvageable. ${ }^{22}$ Yet if Swinski is correct in her observation that 'pro-life' groups at the UN do not work towards the 'greater legitimacy of the UN, ${ }^{23}$ then it may be that Croft's view, that 'pro-family' organisations are simply using the $\mathrm{UN}$, remains valid.

What this chapter seeks to uncover is what role the UN plays in 'pro-family' global activism. To do this, I consider the ways that different groups in the 'pro-family' movement have depicted the UN and its activities, and how this is changing over time. The first part of this chapter discusses the ways which the UN is characterised in 'pro-family' texts. The first set of depictions of the UN show the institution as a would-be hegemon, which must be attacked and defeated. The second set portrays the UN as a potentially redeemable organisation which has been hijacked. From this perspective, the UN needs to be changed rather than eradicated. With the continued involvement of 'pro-family' organisations at the UN, it is possible to discern a movement from the first type of depiction to the second, though both perspectives remain present in 'pro-family' discourse. The last part of the chapter considers the tensions in the conflicting 'pro-family' approach to the UN.

\footnotetext{
${ }^{19}$ Butler, op. cit., p. 52.

${ }^{20}$ Ibid, p. 69.

${ }^{21}$ Ibid.

${ }^{22}$ Butler, op. cit., p. 77. See also Buss and Herman, op. cit., p. 57.

${ }^{23}$ See chapter one of this thesis for more on this.
} 
$\underline{\text { Part I: How do 'pro-family' organisations characterise the UN? }}$

The UN as a world government-in-waiting

Despite its increasing involvement with the institution, 'pro-family' organisations have taken issue with the UN and its branch organisations, often arguing that it is a power-hungry organisation that seeks to govern the world. 'Pro-family' texts of this kind can be roughly divided into two categories. The first objection is that the UN is a socialist organisation, using economic redistribution to consolidate its power. In this framework, development funds are seen as a way of forcing poor countries to obey rules laid out by the UN. The second 'pro-family' complaint is that the UN is trying to increase its power by destroying the family, through the promotion of women's and children's rights. These rights are seen as efforts to 'individualise' the people of the world, part of a ploy to do away with any traditional social structures powerful enough to resist the establishment of a 'new world order' headed by the UN.

Development assistance in the first 'pro-family' framework is a form of welfare dependency on a global scale, used to bribe or discipline countries in order to make them conform to the will of the increasingly powerful UN. In a 2006 article, Crouse accuses the UN of using development assistance as a way of interfering in the national sovereignty of poor countries. As was discussed in the previous chapter, CWA has frequently depicted the UN as a globalist entity, attempting to control the world through its role as a regulatory body, and warns that ceding any power to the international organisation necessarily harms the US and its citizens. In Crouse's analysis, the UN has become a source of 'easy money,' which has enabled it to grow in power at the expense of poor countries' ability to govern their own affairs. According to Crouse, the UN 'maintains international control' using a carrot and stick approach to reward compliance and punish non-compliance. ${ }^{24}$

\footnotetext{
${ }^{24}$ Crouse, J. S. (2006) 'Misguided Attempts to Eradicate Global Poverty: An analysis of the National Council of Churches Study Guide on the Millennium Development Goals,' Concerned Women for America, 15 August, 2006. Available at http://www.cwfa.org/articledisplay.asp?id=11307\&department=BLI\&categoryid=reports [last accessed 11/08/09].
} 
HLI, for example, sees its role as protecting small countries from the overarching power of the UN. In a 2006 Special Report, HLI informs its readers that the UN strategically applies pressure to small countries to change their abortion laws, as part of an 'aggressive international culture of death. ${ }^{25}$ HLI sees this culture as intimately connected with the rise of progressive NGOs associated with the UN. In Nicaragua, Euteneuer warns of an alliance between 'leftist' socialist NGOs and the UN, who are carrying out 'their new plan to dominate the world with the culture of death. ${ }^{26}$ The idea that left-wing NGOs are using abortion to dominate the world may seem fanciful to some observers of the 'pro-family' movement, but it reveals the degree to which sexual and reproductive issues have the capacity to save or destroy the world in Euteneuer's view. HLI, denied accreditation at the UN, has not significantly changed its view of the organisation; the UN is still seen as a bullying and corrupting Goliath, forever tainted by association with the 'culture of death.'

Early CWA texts were similarly hostile to the UN. In a 1997 article entitled 'United Nations attempts to steal US sovereignty,' the author argued that the US should cut funding to the UN, due to 'gross financial mismanagement' and 'radical social policies which most Americans do not agree with. ${ }^{27}$ Environmentalism was also seen as a means by which the UN sought to increase its ideological control over the US in CWA texts. 'Sovereignty under siege: the United Nations' plan for your home' is one such article. ${ }^{28} \mathrm{CWA}$ warns its readers of the Clinton Administration's collusion with the UN, facilitating a 'UN land-grab.' ${ }^{29}$ Early CWA texts were profoundly sceptical of the intentions of the UN as an institution, seeing gains at the UN as necessarily problematic for the US. ${ }^{30}$ Though this characterisation is

\footnotetext{
${ }^{25}$ Human Life International (2006) Special Report, no. 264, December 2006, p. 5. See http://www.hli.org/sr_july_06.pdf [last accessed 13/11/06].

${ }^{26}$ Euteneuer, T. J. (2003) 'Pro-Life Missionary Trip: Nicaragua,' Human Life International, 24 -28 June 2003. Accessed at http://www.hli.org/mission_nicaragua_2003.html [last accessed 21/12/ 06]. ${ }^{27}$ CWA (1997) 'United Nations attempts to steal US sovereignty,' Concerned Women for America, 5 March, 1997. Available at http://www.cwfa.org/articles/1830/CWA/nation/index.htm [last accessed 24/08/09].

${ }^{28}$ Macleod, L. A. (1997) 'Sovereignty Under Siege: the United nations plan for your home,' Concerned Women for America, April 1, 1997. See http://www.cwfa.org/articles/1832/CWA/nation/index.htm [accessed 24/08/09].

${ }^{29}$ Ibid. See also 'Eco-warriors want your land,' on the same webpage.

${ }^{30}$ A 1998 CWA article argues that the UN is opposed 'to the notion of nationalism and is working to promote many policies that undermine US sovereignty and hinder the interests of the American people.' CWA (1998) 'The United Nations,' Concerned Women for America, 15 April 1998. Available at http://www.cwfa.org/articles/1852/CWA/nation/index.htm [last accessed 24/08/09].
} 
changing with CWA's increased involvement at the UN, it persists as a theme in the discourse of this organisation.

CWA authors also see the UN as corrupted by socialist tendencies, although unlike HLI, the focus of CWA's criticism changes over time. In her critique of the 2002 UN Commission on Sustainable Development, Crouse denounces the Summit as yet another attack on affluent nations, with every session calling for the redistribution of wealth from rich to poor countries. ${ }^{31}$ Crouse sees the UN as opposed to capitalism itself, complaining in 2002 that 'every United Nations conference turns into ... attacks against capitalism and free trade. ${ }^{32}$ Her analysis of this event goes on to describe a North-South divide that prevented consensus on development, due to the 'bitter, angry delegates' from the South who wanted to 'rub the North's affluence right back in the faces of the developed nations. ${ }^{33}$ She concludes her description of the event firmly on the side of the North, writing that 'as long as they [the South] refuse to accept personal responsibility, there can be no healing and no restoration.' 34 This echoes an older Christian Right approach to foreign aid mentioned in the introduction, which sees poor countries as suffering because they lack the moral values required for successful economic development.

CWA depictions of the UN can not be said to improve after the inauguration of George W. Bush, but they do change in a noticeable way. Numerous earlier articles had warned that Clinton was strongly allied with the UN and together, they sought to augment their power over the people and families of the world. ${ }^{35}$ From 2001, CWA continues to depict the UN as power-hungry, but it becomes less of a threat to the US, thanks to the protection provided by the new Bush Administration. Reporting on the World Summit for Children in 2001, CWA writes that many "profamily' people had 'wondered about US/UN policies' under the new

\footnotetext{
${ }^{31}$ Crouse, J. S. (2002) 'Stumbling Blocks on the road to Johannesburg,' January 1, 2002, Concerned Women for America. See http://www.cwfa.org/articledisplay.asp?id=1955\&department=CWA\&categoryid=nation [last accessed 19/08/09].

${ }^{32}$ Ibid.

${ }^{33}$ Ibid.

${ }^{34}$ Ibid.

${ }^{35}$ See for example, CWA (1999) 'Executive Orders: A blueprint for dictatorship?' Concerned Women for America, 1 December 1999, available at http://www.cwfa.org/articles/1668/CWA/misc/index.htm [last accessed 29/09/09], where Clinton is accused of having a 'United Nations-inspired agenda.'
} 
Administration. Happily for CWA, the new delegation appeared to toe the "profamily' line, and the reporter has the following to say about the delegations new emphasis on 'parental authority:'

'You can imagine the sigh of relief among pro-family NGOs - as our children return from the grasp of the "global parenting" movement. ${ }^{, 36}$

Contrasting the collusion of Clinton with the staunch resistance of the new Bush Administration, CWA's assessment of the 'pro-family' role at the UN begins to change around this time. CWA continues to criticise the UN, but in the name of defending families in other countries, rather than defending the US. Perhaps sensing that American families were now well defended (thanks to the "new sheriff in town ${ }^{37}$ ) CWA felt able to pursue a new offensive in its attack on the UN. 'Profamily' discourse during the Bush Administration begins to appeal more and more to an audience outside the US, calling on this audience to resist the 'anti-family' agenda of the UN.

This is because the UN's agenda, say 'pro-family' activists, is completely out of touch with what the people of the world want. 'Despite efforts to undermine the natural family in the United Nations,' suggest Dobson and Carlson in 2000, the world's people agree 'that the natural family is the fundamental social unit. ${ }^{38}$ The alleged 'anti-family' effort at the UN is seen as a strategy which will bring about a global standardisation of culture and society, made in the image of the individualistic and godless global citizen. Against this purported endeavour, Focus on the Family states its steadfast opposition to 'any and all domestic or international efforts of social parenting movements that would define children as wards of the state. ${ }^{39}$ In this way, Focus implies a desire on the part of its opponents for a world in which governing agencies control childrearing, with parents relieved of this role.

\footnotetext{
${ }^{36}$ CWA (2001) 'World Summit for Children: 1 Feb 2001,' Concerned Women for America, 1 January 2002, available at http://www.cwfa.org/articles/1929/CWA/nation/index.htm [last accessed 29/09/09].

${ }^{37}$ Austin Ruse quoted in ibid.

${ }^{38}$ Dobson, J. C. (2000) 'The Future of the Family,' Focus on the Family, January 2000. Available at http://www2.focusonthefamily.com/docstudy/newsletters/A000000794.cfm [last accessed 19/08/09].

${ }^{39}$ Focus on the Family (no date) 'Parental Rights Statement,' available at http://www.citizenlink.org/FOSI/education/pe/A000001425.cfm [19/08/09].
} 
In this dystopic scenario, having control of the education and upbringing of children, the UN grows in power at the expense of families, tradition and variety.

'Pro-family' authors posit the 'natural family' as the most important bulwark against the growing power of a hegemonic UN. One speaker at the Mexico WCF even notes in the introduction to his speech that 'the family is more important than the United Nations,' to the survival of human society. ${ }^{40}$ In fact, in 'pro-family' discourse, the UN is not just outranked by the family in importance, it is jealously trying to eliminate it. For this reason, UN treaties, conventions and declarations that purport to advance the cause of women and children are eyed with suspicion by 'pro-family' activists. In one example, responding to the Children's Convention in 2002, Carlson suggests that the Convention not only undermines parents' authority, it also favours 'radical' social science approaches to ordering society over religion and tradition, and 'prevents nations and peoples from sheltering their own unique cultures. ${ }^{41}$ Though he does not explicitly say who or what it is that cultures must be sheltered from, it is clear that Carlson still has some global standardising ideology in mind that keeps him wary of the UN. Carlson laments that the UN now functions within a 'post-family' framework. ${ }^{42}$ The job of 'pro-family' activists, then, is to challenge the UN's application of its 'anti-family' influence.

HLI definitely sees itself as defending the world against the UN and its agencies. In a 2003 'pro-life missionary trip' to Colombia, Euteneuer suggests that the UN's way of preventing the spread of HIV among children is to throw condoms at them. 43 'It's absolutely unbelievable,' exclaims Euteneuer, 'what lengths these people will go for the sole purpose of destroying a culture.' ${ }^{44}$ Consequently,

\footnotetext{
${ }^{40}$ Sprigg, P. (2004) 'Homosexuality: The Threat to the family and the attack on Marriage,' World Congress of Families III, Mexico City. Available at http://www.frc.org/get.cfm?i=PD04F01 [last accessed 19/08/09].

${ }^{41}$ Carlson, A. (2002) " "The Family” at the United Nations: What Went Wrong? And How To Get It Right Again,' remarks to the seminar on the UN Convention on The Rights of the Child, Awakenings Conference, The Cloister, Sea Island, Georgia. The Howard Center, http://www.profam.org/docs/acc/thc_acc_cloister020104.htm [last accessed 19/08/09].

${ }^{42}$ Ibid.

${ }^{43}$ Euteneuer, T. J. (2003) 'Pro-Life Missionary Trip: Colombia.' Human Life International, 6 October 2003. Accessed at http://www.hli.org/mission_colombia 2003.html [last accessed 21/12/06].

${ }^{44}$ Ibid.
} 
Euteneuer declares that 'it is HLI's mission to at least slow the advance of these satanic forces in the rest of the still-sane world. ${ }^{45}$

Early CWA texts agree that the world needs to be protected from the UN. As has already been noted, globalization has often been considered as an item on the UN's agenda in CWA texts (rather than a process that occurs beyond the control of the organisation). One CWA author writes in 1998 that

'In equating peace with globalization, and ultimately, a world government, the UN is proposing a radical government of tyranny, wherein "tolerance" is only a byword for those who support the establishment. ${ }^{46}$

Here CWA takes a classic conservative position against tolerance: conservative values will not be deemed worthy of toleration by those who hold power in the UN, whereas the ideas espoused by 'UN radicals' will be protected.

\section{Parts of the UN are corrupted and must be exposed}

'Pro-family' organisations frequently attack UN agencies and treaty implementation committees as the tools of totalitarian elites, arguing that they are attempting to destroy traditional family structures. By breaking up families, this argument goes, the UN disables the major obstacle in its path towards world domination. Development agencies are thus cast as pleasant façades concealing a darker purpose, and the role of 'pro-family' organisations is to expose the 'true' agendas of UN agencies.

A 1999 CWA article on the UN's activities in Kosovo accuses the UN Population Fund (UNFPA) and the Planned Parenthood Federation of America (PPFA) of 'taking advantage of suffering women to further their own agenda.' Criticising the supply of emergency contraceptive health kits for rape victims in the region, CWA accuses UNFPA of increasing the suffering of refugees by supplying them with equipment that endangers their lives. ${ }^{47} \mathrm{CWA}$ draws attention to Kosovo's relatively

\footnotetext{
${ }^{45}$ Ibid.

${ }^{46}$ CWA (1998) 'The United Nations,' Concerned Women for America, 15 April, 1998. Available at http://www.cwfa.org/articledisplay.asp?id=1852\&department=CWA\&categoryid=nation [12/10/06]. ${ }^{47}$ CWA (1999) 'UNFPA and PPFA advance the victimization of women in Kosovo,' Concerned Women for America, 16 April, 1999. Available at
} 
high birth rate, suggesting that the country is 'a prime target for population controllers like UNFPA. ${ }^{48}$ The article concludes that

‘... UNFPA and PPFA are taking advantage of desperate, vulnerable refugee women.

They are attempting to program them with the UN's ideas about sexuality and abortion. $^{49}$

CWA texts on CEDAW also stress the threat that the UN poses to vulnerable women. In 2002, in an article entitled 'CEDAW preys on needy women,' Crouse complains that CEDAW is actually a decoy, through which radicals seek to impose their extremist ideology on unwitting nations:

'The CEDAW treaty is just a red herring that cloaks radical social engineering in socalled women's concerns in order to draw attention away from its heavy-handed imposition of a radical ideology. ${ }^{, 50}$

CEDAW is depicted as a 'radical' UN project that will replace 'traditional values' with a new sterile ideology that tries to erase any essential differences between men and women. CEDAW threatens women in developed countries too, says CWA, because it 'unravels America's families and forces women to model themselves after global feminists' ideal image. ${ }^{51}$ In a 2004 article, Crouse states that CEDAW is a

'...leftist utopian wish list: comparable worth, paid maternity leave, a national network of child care, free maternity-related health care, gender-blind military service, and quota-determined political parity for women. ${ }^{52}$

Crouse takes the position that women would be better served by improving sanitation and medicine (presumably not in the areas of sexual health), and, more

http://www.cwfa.org/articledisplay.asp?id=1374\&department=CWA\&categoryid=life [last accessed 19/08/09].

${ }^{48}$ Ibid.

${ }^{49}$ Ibid.

${ }^{50}$ Crouse, quoted in CWA (2002) 'CEDAW Preys On Needy Women: Political Maneuvering is Sheer Opportunism,' Concerned Women for America, June 13, 2002. http://www.cwfa.org/articledisplay.asp?id=1578\&department=BLI\&categoryid=media [last accessed 23/08/09].

${ }^{51}$ MacLeod, L. and C. Hurlburt (2000) 'Exposing CEDAW,' Concerned Women for America, 1 September 2000, available at http://www.cwfa.org/articledisplay.asp?id=1971\&department=CWA\&categoryid=nation [last accessed 29/09/09].

${ }^{52}$ Crouse, J. S. (2004) 'The Stalking Horse Named CEDAW,' Concerned Women for America, 16 January, 2004. Available at http://www.beverlylahayeinstitute.org/articledisplay.asp?id=5108\&department=BLI\& categoryid=reports [last accessed 20/08/09]. 
elusively, working to provide them with 'the freedom that brings human dignity., ${ }^{, 53}$ She argues that CEDAW is attempting to re-define the family, through its promotion of the idea that the responsibility for children rests on the wider community, not just parents. 'Feminists,' Crouse writes in 2004, 'are at the forefront of those who are trying to convince the world that "father and mother" are just words. ${ }^{54}$ Believing that feminism challenges the very identity of parents, Crouse, like Focus, sees CEDAW and its architects at the UN as threatening to deliver the responsibility of raising children from parents to the state, and thereby further centralising power in the hands of UN elites.

In 2002, the Howard Center takes a similar stance in opposition to CEDAW, with Carlson concerned that

'Taken as a whole, CEDAW strips the family of all autonomy and authority. It gives moral legitimacy solely to the isolated, radical individual. And it grants sweeping power to the state to regulate, restructure, and even abolish the natural family. ${ }^{55}$

Carlson's rendering of the Women's Convention paints the document as a revolutionary tool indeed. Carlson sides with moral collectivism over the more liberal agenda promoted by CEDAW, derided here as the promotion of the 'isolated, radical individual.' Like Crouse in her statement about feminists rejecting the terms 'father' and 'mother,' Carlson depicts CEDAW as a tool that pits individuals against families as the social units of value. This individualism is seen as an item on the UN's 'post-family' agenda, and supports the UN in its alleged efforts to dismantle 'natural families' and pursue its 'radical ideology.

By stressing that UN ideologues are advancing their own agenda ahead of what women want or need, C-Fam activists claim that the UN is now embarking on a massive overhaul of familial, societal and political relations. Suspicious of UN's emphasis on sexual and reproductive rights, C-Fam author Douglas Sylva argues

\footnotetext{
53 Ibid.

${ }^{54}$ Crouse, J. S. (2004) 'Feminism and the Family,' Remarks at the World Congress of Families III, Mexico City, March 29, 2004, available at Concerned Women for America, http://www.cwfa.org/articles/5435/BLI/commentary/index.htm [13/3/08].

${ }_{55}$ Carlson, A. (2002) “The Family” at the United Nations: What Went Wrong? And How To Get It Right Again,' remarks to the seminar on the UN Convention on The Rights of the Child, Awakenings Conference, The Cloister, Sea Island, Georgia. The Howard Center, http://www.profam.org/docs/acc/thc_acc_cloister020104.htm [15/2/2007].
} 
that UN development agencies have replaced essential development services with an ideologically charged agenda. ${ }^{56}$ Sexual and reproductive rights, then, are seen as part of a project that is intended to undermine motherhood and family, and UN agencies are at the forefront of this effort.

This focus on UN agencies and conventions allows 'pro-family' organisation to isolate the 'bad guys' away from the UN in general, and enables them to view the $\mathrm{UN}$ as potentially salvageable. Though this is by no means a clean break, around 2002 and 2003, many 'pro-family' organisations begin to depict the UN as organisation that has been captured by 'radical' ideologues. Having differentiated between the parts of the UN that they see as redeemable and those they argue should be dissolved, 'pro-family' organisations begin to represent the UN in a more favourable light. The General Assembly and the UN Declaration of Human Rights start to be elevated as potentially beneficial, whilst certain UN agencies are singled out for sustained 'pro-family' hostility. The following section discusses the different ways that 'pro-family' organisations frame the UN as hijacked by 'antifamily' enemies, rather than being an inherently sinister and power hungry organisation in itself.

\section{The UN must be rescued}

'Pro-family' organisations increasingly depict the UN as a legitimate organisation that has been captured by enemy organisations and ideas. There are a number of potential hijackers in this 'pro-family' framework. Feminists are the most prominent, but homosexuals, environmentalists and liberals are also charged with being part of the 'anti-family' alliance that has taken over the UN. A major aspect of this takeover in the 'pro-family' view is that the 'real needs' of people in developing countries are ignored and even made worse by the activities of UN agencies. 'Pro-family' activists suggest that UN elites - often feminists - are using the suffering of women in developing countries to further their agenda and increase their global influence.

\footnotetext{
${ }^{56}$ See pages 3-16 of Sylva, D. (2003) 'The United Nations Children's Fund: Women or Children First?' International Organisations Research Group, Catholic Family and Human Rights Institute White Paper, p. 84. See https://www.c-fam.org/docLib/20080424_Number 3 UNICEF 2003.pdf [last accessed 20/08/09].
} 
Leaders in the 'pro-family' movement argue that the UN's Universal Declaration of Human Rights conveys a 'pro-family' set of values. Activists who take this view see the problem with the UN in the form of a group of UN-savvy progressive organisations and individuals aligned in their efforts to impose their ideological agenda on the rest of the world. These progressives, say some 'pro-family' activists, have made the most headway in UNFPA, the World Bank, and UNICEF. As Buss and Herman and others have observed, the General Assembly is the 'pro-family' movement's preferred venue for its UN activism. The UN is thus dissected into acceptable and unacceptable parts. The role of 'pro-family' organisations then, is not to bring down the UN, but to return it to its original 'pro-family' mandate.

In the introduction to a 2002 C-Fam 'White Paper' on the activities of UNFPA, veteran Christian conservative activist Patrick Fagan condemns 'the new sex alliance,' which he claims is pitted against 'the old universal family order. ${ }^{57}$ This is a theme that is repeated time and again in 'pro-family' discourse: there were once universally accepted family conventions and identities which served to benefit society, but these must now be defended by 'pro-family' organisations. ${ }^{58}$

Criticising this 'new sex alliance,' 'pro-family' organisations seek to 'expose' UN activities to public scrutiny as a way of shoring up resistance to the international recognition of sexual and reproductive rights. In this same White Paper, Fagan goes on to suggest that:

'Few policies could be so insidiously hostile to other nations than ones that interfere with their intimate family lives. UNFPA is at the forefront of this distortion, this grand experiment of the "new sex" camp to create a new world order. ${ }^{, 59}$

\footnotetext{
${ }^{57}$ Fagan, P. F. (2002), in Sylva, D. A. (2002) 'The United Nations Population Fund: Assault on the World's Peoples,' Catholic Family and Human Rights Institute, The International Organisations Research Group, White Paper Series Number Three, p. III. Available via http://www.cfam.org/publications/id.327/pub_detail.asp [last accessed 20/08/09].

${ }^{58}$ Buss and Herman make a similar point in Globalizing Family Values, in reference to the semantics around the Christian Right's opposition to homosexuality: Christian Right activists see the social world so changed that 'normalcy is on the defensive.' See Buss and Herman, op. cit., p. 4.

${ }^{59}$ Fagan, P. F. (2002), in Sylva, D. A. (2002) 'The United Nations Population Fund: Assault on the World's Peoples,' Catholic Family and Human Rights Institute, The International Organisations Research Group, White Paper Series Number Three, p. III. Available via http://www.cfam.org/publications/id.327/pub_detail.asp [last accessed 20/08/09].
} 
Fagan emphasises the 'newness' of this liberal 'experiment' in juxtaposition with older conservative moral laws surrounding sex, as well as suggesting to his audience that these ideas are not old enough to be entrenched, so can still be fought off. Interference is also stressed: in Fagan's view, nations and families would be better off without the interference of the UN. Feminists at the UN, says Fagan, dream of a 'scientific socialist controlled utopia of just the right number of people, of health, efficiency, and plenty. 60

CWA also depicts feminists as seeking to control the UN. 'Is there no end to the power grabs of the women at the United Nations?' ${ }^{61}$ asks Crouse in 2006, in response to a proposed UN office for women's affairs. Concerned at the degree to which 'the feminist agenda' has been mainstreamed at the UN, Crouse protests that 'for decades the feminists have dominated sessions at numerous other UN conferences. ${ }^{62}$ All this has done, in Crouse's view, is increase the influence of feminists at the UN at the cost of addressing real issues faced by women in poor countries. In later CWA texts, depictions of the UN as an evil entity have given way to representations in which the organisation could do some good if feminists were removed from it.

C-Fam has taken this position for some time, charging feminists at the UN with seeking to extend their authority far beyond the areas in which a focus on women is appropriate. One Friday Fax notes that feminists have significant influence within UN committees which discuss:

'population, children, housing, aging, the disabled, women, human rights, refugees, and the family. UN feminists, years ahead of pro-family forces, have found ways to include their agenda in all of these areas. ${ }^{, 63}$

\footnotetext{
${ }^{60}$ Ibid.

${ }^{61}$ Crouse, J. interviewed in Singson, S. (2006) 'Senior UN Official Outlines Vision for New UN Women's Office,' Catholic Family and Human Rights Institute Friday Fax, vol. 9, no. 47, November 9, 2006. Available at http://www.c-fam.org/publications/id.487/pub_detail.asp [last accessed 20/08/09].

${ }^{62}$ Ibid. Gender equality is given similarly short shrift in the same article: 'Having another initiative for 'gender equality,' argues Crouse, 'would establish another roadblock to having the real needs of women addressed.'

${ }^{63}$ Ruse, A. (1998) 'New Session of the UN General Assembly Begins Work in New York City,' Catholic Family and Human Rights Institute Friday Fax, Vol.1, No. 48, September 11, 1998. Available at http://www.c-fam.org/publications/id.57/pub_detail.asp [last accessed 20/08/09].
} 
Many feminists might find it surprising that anyone would find their input inappropriate in any of these areas, given that they do all affect women, and often in ways that are different from men. For C-Fam, however, they are not women's issues, and trying to make them so shows the degree to which parts of the UN have undergone a 'feminist takeover. ${ }^{64}$ In this way, C-Fam portrays its international responsibility as holding back the interfering and bullying ${ }^{65}$ feminists within the $\mathrm{UN}$, and protecting smaller nations from their influence.

CWA frequently takes this position. In a response to a call for increased US funding for UN-administered vaccinations and antibiotics to combat the spread of childhood diseases, Crouse suggests that these diseases are as widespread as they are because of UN feminists' narrow-minded focus on abortion:

'For at least the past decade, the United Nations has been so focused on abortion that it has totally neglected other health issues that could have been reduced by now -and that sad fact has caused millions of deaths around the world. ${ }^{, 66}$

Seeing advocacy for reproductive health and safe motherhood as coming at the cost of other health interventions, CWA accuses the UN of prioritising feminist ideology above saving lives. Similarly, numerous C-Fam publications accuse UN agencies of wasting health dollars on promoting equality. In one author's words, the UN children's agency UNICEF is 'wander[ing] further and further from its official mandate to feed and medically treat suffering children. ${ }^{67}$ Similarly, commenting on the five-year review of the International Conference on Population and Development, C-Fam argues that developing country representatives also disagree with what they see as the UN's emphasis on overpopulation. In C-Fam's

\footnotetext{
${ }^{64}$ This term is used in a 2003 Friday Fax, entitled: 'C-Fam Releases Major Report on Radical Feminist Takeover of UNICEF,' available at https://www.cfam.org/publications/id.305/pub_detail.asp [last accessed 20/08/09].

${ }^{65}$ See Ruse, A. (1999) 'Chairman Criticized/ Many Nations Reserve on Final Cairo+5 Document,' Catholic Family and Human Rights Institute Friday Fax, vol. 2, no. 35, July 8/9, 1999. Available at https://www.c-fam.org/publications/id.98/pub_detail.asp [last accessed 20/08/09].

${ }^{66}$ Crouse, J. S. (2006) 'Misguided Attempts to Eradicate Global Poverty: An analysis of the National Council of Churches Study Guide on the Millennium Development Goals,' Concerned Women for America, 15 August, 2006. Available at http://www.cwfa.org/articledisplay.asp?id=11307\&department=BLI\&categoryid=reports [last accessed 11/08/09].

${ }^{67}$ Ruse, A. (1998) 'UNICEF Uses American Media Giants to Spread Feminism to Developing World,' Catholic Family and Human Rights Institute Friday Fax, vol. 1, no. 51, October 2, 1998. Available at https://www.c-fam.org/publications/id.60/pub detail.asp [last accessed 20/08/09].
} 
framework, developing countries are frustrated by UN agencies' lack of interest in 'legitimate' development concerns. ${ }^{68}$

Another reason C-Fam sees ideologues at work at UNFPA is the continued emphasis on policies that C-Fam believes 'haven't worked,' as exemplified in the following Friday Fax:

'UNFPA admits that AIDS has not been brought under control, noting that, "Despite expanding prevention activities, some 5 million new infections are occurring each year." However, the report then goes on to endorse policies that have not worked, most notably "promoting the correct and consistent use of condoms.",69

Both UNFPA and UNICEF have been targets of investigation by C-Fam's International Organisations Research Group, with the paper on UNFPA calling for suspension of funding pending a thorough investigation by donor countries into the organisation's alleged support of human rights abuses. ${ }^{70}$ The UNICEF paper: 'women or children first?' characterises a feminist takeover of the organisation, in which the needs of children are now totally subjugated to the needs of women in this institution. The author, Sylva, writes that

'These ideological shifts - seismic shifts for an agency once interested in teaching mothers home economics as a practical method of promoting the welfare of children - have not gone unnoticed. ${ }^{71}$

Seeing the desires of women and children in zero-sum terms, the paper ultimately recommends a number of policy changes, including the removal of 'radical feminism' as the UNICEF's guiding principle. ${ }^{72}$

\footnotetext{
${ }^{68}$ See, for example, Ruse, A. (1999) 'UNICEF Believes State of War Exists Against World's Women and Children,' Catholic Family and Human Rights Institute, Friday Fax, vol. 3, no. 7, December 31, 1999. Available at https://www.c-fam.org/publications/id.122/pub detail.asp [last accessed 20/08/09].

${ }^{69}$ C-Fam (2004) 'UNFPA Report Claims Reproductive Rights Still Key to Development,' Catholic Family and Human Rights Institute Friday Fax, vol. 7, no. 39, September 17, 2004. Available at https://www.c-fam.org/publications/id.373/pub_detail.asp [last accessed 20/08/09].

${ }^{70}$ Sylva, D. A. (2002) 'The United Nations Population Fund: Assault on the World's Peoples,' Catholic Family and Human Rights Institute, The International Organisations Research Group, White Paper Series Number Three, p. III. Available via http://www.cfam.org/publications/id.327/pub_detail.asp [last accessed 20/08/09].

${ }^{71}$ Sylva, D. (2003) 'The United Nations Children's Fund: Women or Children First? International Organisations Research Group,' Catholic Family and Human Rights Institute White Paper, p. 84. See https://www.c-fam.org/docLib/20080424_Number_3 UNICEF_2003.pdf [last accessed 20/08/09].

${ }^{72}$ Ibid, pp. 89-92.
} 
Focus takes the same line when it condemns UNFPA for sending contraceptives to Myanmar after the Boxing Day tsunami, before assistance with 'food, shelter and medication. ${ }^{73}$ Only a world nearly devoid of God,' says a Focus spokesperson, 'could give supplies denying life before necessities to sustain life. ${ }^{74}$ For "profamily' groups, then, even if parts of the UN are benign, agencies such as UNICEF and UNFPA remain beyond the pale.

'Pro-family' organisations accuse UN elites of wilful anti-democratic behaviour which promotes sexual and reproductive rights against the will of the global populace, and in opposition to the intentions of the UN's founders. The Howard Center, in particular, looks back with nostalgia to a time in which the UN steered clear of family issues, before what Carlson refers to as 'the UN press into social and family policy. ${ }^{75}$ His view, which forms a part of the justification for the WCF, is that the UN has been profoundly altered since its inception. He states that

'.. the rise of a militant secular, anti-family political ideology transformed the United Nations from an initially friendly venue into a vehicle dangerous to families, to parents, and to children. ${ }^{, 76}$

The danger posed, in Carlson's view, is that the UN has become an end in itself, an engine of social change reaching far beyond the scope of issues for which it was created. Because this change is liberal in nature, appealing to the rights of individuals rather than families, Carlson sees the family and indeed 'natural society' ${ }^{77}$ as being undermined by the UN. 'Pro-family' organisations seek to meet

\footnotetext{
${ }^{73}$ Focus on the Family (2008) 'Myanmar receives condoms before food, medicine,' 28 May, 2008. Available at http://www.citizenlink.org/CLBriefs/A000007534.cfm [last accessed 20/08/09]. 
this threat at its source - the UN - with a broad base of international support, to oppose the further liberalisation of sexual and reproductive norms at the global level.

In order to do so, 'pro-family' organisations accept that they must make their arguments on non-religious grounds. Believing strongly in the broad efficacy of their policy positions, there is no evidence to suggest that the organisations see defending them in a secular forum as a problem. What 'pro-family' organisations do object to is what they see as the bias of UN elites towards established progressive organisations and ideas in the debates around and implementation of policies at the UN.

The 'pro-family' lobby at the UN still sees itself as a reviled group, with its activists struggling against a tide of animosity and stealth tactics as they attempt to have their perspectives heard. 'Welcome to the United Nations' states Crouse dryly, as she complains that liberals avoid the democratic process by moving debates to 'private, unannounced meetings.' 'Such shenanigans,' says Crouse, are par for the course' at the UN. ${ }^{78}$ Similarly, Focus asks its followers to pray for its staff and other 'pro-family' activists at the UN: 'It can be a daunting challenge to stand up for righteous principles in what is often a hostile environment; but ... our presence there can - and does - make a difference. ${ }^{79}$

C-Fam also complains about unfair treatment in UN meetings. A 2001 Friday Fax complains that 'pro-family' lobbyists were 'harassed' by UNICEF personnel as they attempted to register for a UN summit on children. ${ }^{80}$ Illustrations of UN agencies' hostility towards 'pro-family' organisations contribute to the 'pro-family' sentiment that secular entities and individuals seek in order to dominate UN

\footnotetext{
${ }^{78}$ Crouse, J. S. (2002) 'Stumbling Blocks on the road to Johannesburg,' January 1, 2002, Concerned Women for America. Available at http://www.cwfa.org/articledisplay.asp?id=1955\&department=CWA\&categoryid=nation [last accessed 20/08/09].

${ }^{79}$ Dobson, J. C. (2005) 'Good News regarding families around the world,' Focus on the Family, July 2005. Available at http://www2.focusonthefamily.com/docstudy/newsletters/A000000762.cfm [last accessed 20/08/09].

${ }^{80}$ Ruse, A. (2001) 'Bush Negotiators Cheered for Conservative Statement at UN Child Summit,' Catholic Family and Human Rights Institute Friday Fax, February 2, 2001, vol. 4, no. 7. Available at http://www.c-fam.org/publications/id.176/pub_detail.asp [last accessed 20/08/09].
} 
proceedings. C-Fam is particularly affronted by what it perceives as a procedural bias against 'pro-family' groups in the UN arena, in which 'anti-family' forces within the UN manipulate the processes and the language of debates in the UN to suit their own agendas. ${ }^{81}$

\section{$\underline{\text { Part II: Tensions }}$}

The General Assembly is legitimate but 'anti-family' forces still control the process 'Pro-family' groups are increasingly viewing the General Assembly as a legitimate place in which the 'pro-family' perspective is respected. In their work in this arena, 'pro-family' organisations rely on delegates from developing countries to represent their views and now frequently portray the General Assembly as an arena of lively debate. Though they do not see it as perfectly democratic by any means, "profamily' organisations now focus most of their energy on influencing resolutions in the General Assembly and other UN meetings with a large number of developing country delegations. This reflects the contention of 'pro-family' organisations that their message has a receptive audience in the more religious and less developed world.

'Pro-family' efforts in the General Assembly do not always translate into satisfactory results, however. When outcomes are not consistent with 'pro-family' views, the groups react by either rekindling their general anti-UN stance or their argument that the procedure is biased against them. An example of the first approach is Crouse's 2006 criticism of the National Council of Churches, in which she calls the UN a 'corrupt and bloated international organisation with a long record of ineffectiveness and corruption. ${ }^{82}$ By contrast, Crouse's account of the General Assembly's 2005 decision to ban human cloning makes the following assessment of

\footnotetext{
${ }^{81}$ CWA shares this sentiment - a staff writer at CWA complains that its 'radical' opponents have taken this underhanded approach with CEDAW: 'CWA has learned that at least four radical organizations are working to get CEDAW ratified... CEDAW supporters are pushing its ratification and building grassroots support through low-key events, such as the forum, in order to win passage "under the radar." Stuber, R. (2006) 'Feminists Step Up Attempt to Ratify CEDAW treaty,' Concerned Women for America, 1 March, 2006. Available at http://www.cwfa.org/articledisplay.asp?id=10233\&department=CWA\&categoryid=nation [last accessed 20/08/09].

${ }^{82}$ Crouse, J. S. (2006) 'Misguided Attempts to Eradicate Global Poverty: An analysis of the National Council of Churches Study Guide on the Millennium Development Goals,' Concerned Women for America, 15 August, 2006. Available at http://www.cwfa.org/articledisplay.asp?id=11307\&department=BLI\&categoryid=reports [last accessed 11/08/09].
} 
what this portends: 'it is reassuring that the UN vote signals an international commitment to moving forward in a way that respects the sacredness of human life. ${ }^{83}$

An example of the second approach is C-Fam's complaint that UN elites circumvent definitions hard-won by 'pro-family' organisations and their allies in the General Assembly. 'Pro-family' groups argue that treaty compliance committees use liberal interpretations of key words in documents relating to sexuality and reproduction when they oversee their implementation. For example, in a 2004 discussion about the activities of the UN Human Rights Council, C-Fam complains that treaty implementation committees wilfully misinterpret the term 'reproductive health' to include abortion 'and other new rights,' even while the General Assembly excludes abortion from its definition of reproductive health. ${ }^{84}$ In a 2004 Friday Fax, a C-Fam author suggests that a number of government representatives were concerned that efforts to move a discussion on cloning out of the General Assembly were 'deeply anti-democratic,' suggesting that the move was 'an effort to circumvent three years of public and open debate on cloning at the UN and replace it with the closed-door work of "experts.", 85

A similar case is made over the use of the term 'gender,' recalling that both times the word has been considered by the General Assembly, it has been defined in a way that 'pro-family' groups accept. Despite this, C-Fam is frustrated that the UN Gender Advisor still defines 'gender' as a 'social construct,' because to 'profamily' organisations, this means that it can be changed. ${ }^{86}$ Hence even though CFam has enjoyed increasing influence at the UN, it is still concerned that the structure of the UN produces 'anti-family' outcomes. Despite this, C-Fam clearly

\footnotetext{
${ }^{83}$ Crouse, J. S. (2005) 'Cloning Rejected by UN,' Concerned Women for America, 10 March, 2005, available at http://www.cwfa.org/articledisplay.asp?id=7659\&department=CWA\&categoryid [last accessed 29/09/09].

${ }^{84}$ Singson, S. (2006) 'Controversial 'Rights” Being Pushed at Human Rights Council,' Catholic Family and Human Rights Institute Friday Fax, vol. 9, no. 42. Available at http://www.cfam.org/publications/id.481/pub_detail.asp [last accessed 20/08/09].

${ }^{85}$ C-Fam (2004) 'Girding for UN Defeat, Cloning Advocates Seek to Move Decision to UNESCO,' Catholic Family and Human Rights Institute Friday Fax, vol. 7, no. 33, August 6, 2004. Available at http://www.c-fam.org/publications/id.368/pub_detail.asp [last accessed 20/08/09].

${ }^{86}$ Singson, S. (2006) 'Secretary-General Puts "Gender Equality” At Center Of UN Reform Proposal,' Catholic Family and Human Rights Institute Friday Fax, vol. 9, no. 48, November 16, 2006. Available at http://www.c-fam.org/publications/id.488/pub_detail.asp [last accessed 20/08/09].
} 
sees an advantage to having issues in which it is involved debated in the relatively open forum of the General Assembly. 'Pro-family' investment in the General Assembly is an important indication of the degree to which the groups are now committed to changing the UN, rather than attacking it. Moreover, the consistent appeal to democracy and open debate at the international level shows either a quiet confidence in the popularity of conservative principles at this level, or a tactical decision on the part of C-Fam to at least appear confident of the widespread appeal of its positions. Either way, the organisation sees itself as protecting democracy at the international level, or in the words of a document endorsed by C-Fam, preventing UN officials from undermining 'the values and sovereignty of individual nations. ${ }^{87}$ For 'pro-family' activists, then, the General Assembly is the source of the UN's legitimacy and the primary target of 'pro-family' organisations' activism in their attempt to change the UN.

'Pro-family' efforts at the General Assembly and appeal to the UN's founding documents require the organisations to break with some of their past characterisations of the UN. If they continue to press for their policies at the UN level with increasing success, while encouraging an increase of 'pro-family' activism there, elites in the movement must acknowledge that they are having an impact on the UN. They must acknowledge that they are at least to some degree responsible for the outcomes that they have helped to bring about. In doing this, images of the UN as a 'globalist' entity with a totalitarian agenda are reframed to pinpoint particular enemies within the UN system, rather than the UN as a whole. But who are these enemies?

\section{Will the real 'anti-family' forces please stand up?}

As in the past, 'pro-family' activists are still uncertain about who is playing the lead role of 'anti-family' influence at the UN. Given that most of the policies that 'profamily' organisations oppose are advanced by feminists, one might suppose that feminists would be singled out as the movement's main enemy at the UN. Yet 'pro-

\footnotetext{
${ }^{87}$ C-Fam (2005) 'Conservative Document Endorsed by 700 NGOs Presented to UN Today,' Catholic Family and Human Rights Institute Friday Fax, vol. 8, no. 38, September 9, 2005. Available at http://www.c-fam.org/publications/id.424/pub_detail.asp [last accessed 20/08/09].
} 
family' organisations seem surprisingly reluctant to concede that much power to feminists.

One exception to this is a 2001 article written by Patrick Fagan for the FRC. In this article, Fagan states that feminists and their policies are indeed a major force behind the 'anti-family' changes at the UN. He writes that 'the United Nations has become the tool of a powerful feminist-socialist alliance that has worked deliberately to promote a radical restructuring of society. ${ }^{88}$ In this reading, feminists and socialists are in the driver's seat at the UN. Fagan suggests that UN 'agents' now promote a sexual code of conduct that is indistinguishable from those sought after by feminists: "they are becoming the tenets of a new "moral" code against which all religions, domestic policies and cultures would be judged. ${ }^{89}$ Fagan rounds out his argument by stressing what he sees as the weakness of non-traditional family structures, suggesting that 'if the objective is to increase state control of all functions of society, then the UN approach makes sense.' 90 Making these connections, Fagan hopes to stimulate 'pro-family' action against what he sees as the combination of two 'anti-family' ideologies which now control the UN.

Interestingly, however, Fagan's direct clarification of who is to blame at the UN has not been picked up by 'pro-family' discourse: searches of 'pro-family' websites for 'feminist/socialist alliance' and similar terms show either a lack of awareness of this framework or an unwillingness to use it to describe what has been going on at the UN. The only 'pro-family' activist who comes close to this degree of clarity about the enemies directing the UN is Carlson, who for his part, blames the 'militant secular alliance' (of the Clinton Administration and the EU) in the 1990s for the 'anti-family' outcomes of the 'originally pro-family' UN. And indeed, Fagan himself appears to change his mind about the role of feminists at the UN, describing their activities as cover for other actors at the UN in the following year. In 2002, Fagan, this time writing for C-Fam, suggests that UNFPA bureaucrats are able to disguise the major changes to family, tradition, culture and population they seek to

\footnotetext{
${ }^{88}$ Fagan, P. (2001) 'How UN conventions on women's and children's rights undermine family, religion and sovereignty,' Family Research Council, February 5, 2001. Available at http://www.frc.org/get.cfm?i=LH08H21 [last accessed 02/01/09].

${ }^{89}$ Ibid.

${ }^{90}$ Ibid.
} 
bring about by hiding 'behind the skirts of the new radical woman. ${ }^{91}$ Thanks to feminists, says Fagan, UNFPA's 'assault' is difficult to challenge because UNFPA 'spins criticism of these practices as oppression of women and their rights' (in other words, using feminist arguments as 'spin' rather than truly believing in them). ${ }^{92}$ Feminists make these changes possible, in the 'pro-family' view, but they are not actually responsible for them: feminists function as puppets for people within the UN who wish to promote radical social change on a global scale.

In 'pro-family' discourse, then, women's and children's rights activism at the UN is still often considered a smokescreen for some other objective, perhaps even done on behalf of some other actor. In this conspirational view, women's and children's rights allows agents of the UN to hide their 'true' culturally imperialistic intentions. CWA takes this position in an article entitled 'The Stalking Horse named CEDAW.' In her 2004 article, Crouse denounces the Women's Convention and its proponents as testing the water for sweeping social change controlled and directed by the UN. Crouse is concerned that 'elitists with a radical vision' within the UN are 'eagerly awaiting the opportunity to interject their power into the most intimate seams of the fabric of our personal lives. ${ }^{, 93}$ This vision of UN elites making and enforcing rules to govern our intimate lives - yet concealed behind innocuous sounding treaties - is a repeatedly voiced concern in 'pro-family' discourse. This view also sees the UN as using feminists to further their goals of domination, rather than feminists using the UN to do so.

Why are 'pro-family' organisations so unsure about how to portray the role of feminists at the UN? One possibility is that 'pro-family' leaders do not want to acknowledge that feminist ideologies have been successful or appealing. Moreover, if feminists are in charge, 'pro-family' groups must continue to see the UN in a negative light, rather than as a potentially beneficial organisation within which 'pro-

\footnotetext{
${ }^{91}$ Fagan, P. F. Introduction to Sylva, D. A. (2002) 'The United Nations Population Fund: Assault on the World's Peoples,' Catholic Family and Human Rights Institute, The International Organisations Research Group, White Paper Series Number Three, p. III. Available via http://www.cfam.org/publications/id.327/pub_detail.asp [last accessed 20/08/09].

${ }^{92}$ Ibid, p. vi.

${ }^{93}$ Crouse, J. S. (2004) 'The Stalking Horse Named CEDAW,' Concerned Women for America, 16 January, 2004. Available at http://www.beverlylahayeinstitute.org/articledisplay.asp?id=5108\&department=BLI\& categoryid=reports [last accessed 20/08/09].
} 
family' groups can broadcast their ideas. Another possibility is that blaming particular rather than general enemies can come across as paranoid; undermining the efforts of 'pro-family' elites to move away from this kind of politics. Perhaps most importantly, they are still struggling to decide how to work within the UN system given their ideological constraints: while they are driven to promote binding public moralities and the strengthening of 'tradition,' they are also inclined to oppose the redistribution of wealth and traditional or cultural practices that they see as un-Christian. In this light, it may be easier to keep representing their enemies as unseen, lest they commit themselves fully to a particular course of action that might upset this fine ideological balance.

\section{The UN is bad-but we need it anyway}

Regardless of this uncertainty, 'pro-family' organisations are increasingly willing to support the UN. As one 'pro-family' author puts it, 'the United Nations does some crazy things, but also some very good things. And we have to be prepared to support the good things. ${ }^{94}$ The FRC is similarly supportive of some of the UN's policies, suggesting that while the UN has faults, it has also been a pioneer in the campaign against female genital mutilation, and in attempting to secure 'equal rights for women throughout the world. ${ }^{95}$ FRC is also pleased to see the UN facilitating cooperation between Muslims and Christians. ${ }^{96}$

Likewise, a 2007 article by Crouse firmly declares that the UN is 'worth fixing.' Among other reasons, Crouse defends her position by stating that

\footnotetext{
${ }^{94}$ Cameron, N. (2001) 'Preserving the Ethics in Bioethics,' Focus on the Family, September/October 2001. Available at http://www.citizenlink.org/FOSI/bioethics/A000001352.cfm [last accessed 20/08/09].

${ }^{95}$ Blackwell, K. (2007) 'Protecting the Human Dignity of the Girl Child Worldwide,' Family Research Council, 1 November, 2007. Available at http://www.frc.org/get.cfm?i=PV08L11 [last accessed 20/08/09]. For additional positive appraisals of the UN from Focus and FRC, see also Jenkins, P. (2003) 'Sibling Rivalry Among the Children of Abraham: Global Conflict and Cooperation Between Islam and Christianity,' Family Research Council Witherspoon Lecture, July 18, 2003. Available at http://www.frc.org/get.cfm?i=WT04C01 [last accessed 20/08/09]. Dobson, J. C. (2005) 'Good News regarding families around the world,' Focus on the Family, July 2005. Available at http://www2.focusonthefamily.com/docstudy/newsletters/A000000762.cfm. [last accessed 20/08/09].

${ }^{96}$ Jenkins, P. (2003) 'Sibling Rivalry Among the Children of Abraham: Global Conflict and Cooperation Between Islam and Christianity,' Family Research Council Witherspoon Lecture, July 18, 2003. Available at http://www.frc.org/get.cfm?i=WT04C01 [last accessed 20/08/09].
} 
'there are thousands of people around the world who need to know that they are not alone. At a minimum, the UN provides a platform where their views can be affirmed and reinforced. ${ }^{, 97}$

Thus the UN is portrayed as a structure that has the potential to protect people from oppression, rather than having the UN as the oppressor. Crouse does not explicitly say what her alternative to 'fixing' the UN is, but she has clearly sensed the need to defend the 'pro-family' presence there.

As has already been discussed, the Howard Center is also committed to reforming the UN, rather than rejecting it as an illegitimate entity. Like many other "profamily' organisations, the Howard Center is institutionally attached to the UN, having a strong sense of purpose there and deriving legitimacy from its association with it. Likewise, C-Fam's mission and function would arguably make little sense without the UN, even if it were to decide that the organisation was irredeemable.

\section{Conclusion}

'Pro-family' organisations have for some time depicted the attempts of UN agencies to promote women's and children's rights, redistribute income from rich to poor countries, and promote environmentalism as evidence that the UN as a whole is a power-seeking totalitarian entity. In many ways, this is a predictable result of using an anti-communist global framework to promote 'family values' beyond the US. A link between totalitarianism and the liberalisation of sexual mores explains the UN 'agenda' in earlier 'pro-family' texts.

More recently, however, a new perspective on the UN has begun to emerge in 'profamily' discourse. 'Pro-family' groups affiliated with the UN have begun to frame it as a previously 'family-friendly' and even potentially beneficial organisation that has been hijacked by nefarious 'anti-family' and 'anti-American' forces. Put crudely, the 'pro-family' agenda is changing from 'attack' the UN to 'fix' the UN.

\footnotetext{
${ }^{97}$ Crouse, J. S. (2007) 'The UN: Is it worth fixing?' Concerned Women for America, 5 March, 2007. Available at http://www.cwfa.org/articles/12483/BLI/dotcommentary/index.htm [last accessed 20/08/09].
} 
In both frameworks, the 'natural family' is a centrepiece of the battle. In the earlier view, the 'natural family' is seen as the target of oppressive forces within the UN, and the shield that must be strengthened to protect innocents against the organisation's encroaching power. In the latter view, the 'natural family' is the means by which the 'evil' elements within the UN can be distinguished from the worthwhile ones, and thus the 'natural family' serves as a platform for UN reform and renewal.

Even renewed, however, the UN is ultimately a poor fit for the 'pro-family' movement. Certainly UN policies with which 'pro-family' activists approve are seen as worthy of support. Yet 'pro-family' leaders baulk at wholehearted investment in the UN as an organisation that can be used to bring about 'good' outcomes. A 2004 CWA article asks its readers the following question: 'What does the mission of the church have to do with the UN?' It concludes that

'the mission of the church is to lift up to a suffering world the "Prince of Peace"... hearts are changed and peace is attainable only though the true Gospel message. ${ }^{98}$

In the words of one FRC author writing in 2004, the 'pro-family' movement needs to remember that:

'... we are not closer to the Kingdom of God today than in the early Roman Empire just because we have democracy, human rights, and the United Nations. ${ }^{99}$

This author, reminding the 'pro-family' movement of its Christian roots, sums up a serious question for 'pro-family' activists: what is the purpose of 'pro-family' activism at the UN? This chimes with Buss and Herman's view, that a legitimate international government is impossible without 'Christ at the helm. ${ }^{, 100}$ In pursuing success at the UN, 'pro-family' organisations buy into the potential of human-led progress, an idea that sits uncomfortably with many Christian conservatives. By acting at the UN, the 'pro-family' movement may gain some control over systemic

\footnotetext{
${ }^{98}$ Kiser, K. (2004) 'The United Nations: An Untold Story,' Concerned Women for America, 1 November, 2004, available at http://www.cwfa.org/articles/6623/BLI/reports/index.htm [29/09/09]. ${ }^{99}$ Family Research Council (2004) 'Natural Rights and the American Experiment: Some Problems for Christian Theology,' Family Research Council Witherspoon Lecture, March 12, 2004. Available at http://www.frc.org/get.cfm?i=WT04C02 [last accessed 20/08/09].

${ }^{100}$ Buss and Herman, op cit., p. 30 . They also note that "no matter how "family-friendly" the UN may be, it will always be a form of big government that seeks to replace God.' Ibid, p. 40.
} 
power, as Beyer puts it, but this may be at the cost of losing sight of their ultimate aims and their identity as conservative Christians.

Their identity as political activists does benefit from their activism at the UN, however. The organisations who have it clearly relish their NGO status, which is another complication for a movement that is still, at its core, ambivalent about the worth of the UN. NGO accreditation has the effect of 'mainstreaming' organisations, in that it both constrains behaviour and language - manifest in the difference between the discourse and activities of HLI and C-Fam, for example and announces to 'pro-family' peers and opponents the legitimacy of the organisation, which through its UN status is recognised well outside its ideological community.

Thus while they are still sceptical of the UN, the groups now see themselves as being inextricably connected to the organisation. From seeing the UN as an entity which threatens to annihilate the world's families, tradition, and culture, the organisations now see the UN as a forum in which they can support some parts and policies while they condemn others. In this way, the 'pro-family' justification for globalizing is changing. Originally stepping up because of a perceived threat from the UN, 'pro-family' organisations can now justify their activities at the UN as making a difference by changing the philosophy of the organisation from within.

It could be argued that the changing 'pro-family' views of the UN largely depend on the government which is in charge of the US. I suggest, however, that it has more to do with 'pro-family' investment and involvement in the UN system. While has coincided with who is in the White House, in the sense that Bush facilitated a greater 'pro-family' presence at (and influence on) the UN than Clinton, the organisations would not have changed their views about the UN without being involved in it. By making alliances at the UN, the organisations not only show the developing world that 'they are not alone,' as Crouse puts it, they also re-affirm the widespread popularity of their message amongst themselves. ${ }^{101}$ This suggests that

\footnotetext{
${ }^{101}$ Though 'pro-family' organisations are 'not alone' in their identity as religious conservatives in the international community, they do not always share particularly saintly company. As a number of observers have noted, 'pro-family' allies at the UN include members of the 'Axis of Evil.'
} 
Croft's analysis of Christian Right organisations at work within the UN is incorrect. It overlooks the degree to which 'pro-family' organisations are changing as a result of their presence in that forum: they have become stakeholders in the UN. While it is not difficult to find evidence that some 'pro-family' organisations still look to the UN with distaste, and still see UN elites controlling the processes despite the successes of 'pro-family' organisations at the General Assembly, this chapter shows that there has been a trend towards the desire to retain and reform - rather than simply use - the UN. In this way, the continued presence of 'pro-family' organisations at the UN is justified. The UN offers 'pro-family' groups the opportunity to challenge arguments about the narrow applicability of their views, and provides them with additional networking possibilities in the developing world. Yet in being absorbed into the UN, the 'pro-family' movement has essentially lost a very important enemy. The 'pro-family' presence there legitimates the UN as a democratic forum in which conservative voices are now heard loud and clear. The UN can no longer be a threatening entity in 'pro-family' discourse; something else must take that role.

The findings of this chapter raise important questions about the role of feminists in the 'pro-family' worldview. In some 'pro-family' articles, Feminists, with their liberal, socialist, and environmentalist allies, are accused of pressing for an 'antifamily' agenda through the UN. They are charged with inserting their agenda into areas well beyond their mandate, for seeking to advance a gender-free 'new world order,' and for numerous other assaults on the 'natural family.' Yet feminism is also ridiculed as a bizarre ideology in 'pro-family' discourse, and feminists are sidelined as the pawns of a more powerful (and as yet unnamed) foe. If the UN is to be redeemed or defeated, and more generally, if 'pro-family' organisations are going to achieve the global renewal of 'natural family' values, their ambiguity about feminism and the global role of feminists must be addressed. It is to this "profamily' effort I now turn. 


\section{Chapter Five: Radicals and Basket-Cases: 'pro-family' characterisations of} feminism

'...the feminists had infiltrated the meeting and planted their operatives around the perimeter of the room like a feminist noose.'

Thomas Euteneuer, Human Life International, $2002^{1}$

Resisting the influence of feminism at the global level has been a key aspect of the expansion of 'pro-family' activism beyond US borders. While 'liberals,' 'globalists,' 'socialists' and others do feature as 'anti-family' forces (and are often associated with feminism), 'pro-family' organisations have most often justified their global activism through their opposition to feminist advances and the international organisations that they believe are in thrall to feminist ideas. This chapter considers the ways in which international 'pro-family' organisations characterise feminism, and whether this is changing over time.

Observers of 'pro-family' groups agree that while earlier texts were uniform in their disparagement of feminism, there has been a growing tendency to marginalise only certain types of feminism in the discourse of the Christian Right. Buss and Herman suggest that Christian Right groups split feminism into 'radical' or 'gender' feminism, and another kind of feminism they find acceptable. ${ }^{2}$ They quote Sara Diamond, who notes that 'even on the Right, it is no longer politically correct to make direct attacks on women's equality.' 3 Butler agrees that 'pro-family' organisations dissect feminism into a version they find tolerable and 'radical feminism,' which 'pro-family' groups see as an effort to turn women against men, among other things. ${ }^{4}$ This separation, Butler suggests, may be an acknowledgement that feminist perspectives have become normalised, or it may reflect the 'capacity of religious conservatives to integrate new ideas' into their agenda. ${ }^{5}$ Both Buss and Herman and Butler note that many 'pro-family' organisations now depict feminism

\footnotetext{
${ }^{1}$ Euteneuer, T. J. (2002) 'Pro-Life Missionary Trip: Argentina,' Human Life International, 5 June, 2002. Accessed at http://www.hli.org/mission_argentina_2002.html [last accessed 21/12/06].

${ }^{2}$ Buss, D. and D. Herman (2003) Globalizing Family Values: the Christian Right in International Politics, (Minneapolis: University of Minnesota Press), p. 40.

${ }^{3}$ Ibid, p. 40.

${ }^{4}$ Butler, J. S. (2006) Born Again: The Christian Right Globalized (London: Pluto Press), pp. 16-17.

${ }^{5}$ Ibid, p. 16.
} 
as a 'noble cause,' hijacked by 'radicals,' (similar to the way that the UN has been depicted in 'pro-family' discourse.

Buss and Herman observe that feminist activism provokes two contradictory responses in 'pro-family' politics: feminists are both the actors most often identified as the force behind 'anti-family' changes, while at the same time they are not really taken seriously as a threatening force. ${ }^{6}$ This observation provides an important way of understanding how feminism fits into the 'pro-family' view of the world. If feminists and their ideas are powerful, then international 'pro-family' activism can be understood as opposing the kind of feminism they do not like, and promoting a 'pro-family' form of feminism in its place. On the other hand, if feminists are a minimal threat, it falls on 'pro-family' activists to seek out the real forces behind the 'anti-family' changes they oppose, and target those agents instead.

In this second case, are Herman's 'unseen enemies' - those presumed to be 'hiding behind' feminism - sustaining 'pro-family' interest in the global realm over time, or is feminism becoming a specific and visible 'anti-family' enemy in 'pro-family' discourse? With this question in mind, 'pro-family' discourse on feminism in this chapter is divided between characterisations of feminism as a powerful agent of 'anti-family' change, versus depictions of feminism as a symptom of other (more powerful) 'anti-family' forces. The last part of this chapter considers the issues raised by 'pro-family' characterisations of feminism.

\section{Part I: Characterisations of feminism in 'pro-family' texts}

The first part of this chapter looks at how feminists and feminism are characterised by 'pro-family' organisations. Noting the frequency with which the groups attach the term 'radical' to feminism, this section begins with a discussion of the ways 'pro-family' groups attempt to marginalise feminist NGOs who promote sexual and reproductive health and rights. Related to their charge of radicalism is the characterisation of feminism as the rejection of all forms of sexual morality. This is seen as an effort to liberate men, women and children from the 'traditional' norms and responsibilities that 'pro-family' organisations see as vital to the cohesion of

\footnotetext{
${ }^{6}$ Buss and Herman, op. cit. p. 41.
} 
society. This effort is depicted as a kind of worldwide social experiment conducted by powerful 'radical' feminists. Dangerous feminists have made considerable headway in the industrialised world, say 'pro-family' activists, and their influence needs to be stopped before people from the South suffer the same fate as the 'dying' West.

Another common 'pro-family' response to the increasing influence of feminism and feminist NGOs has been to argue that their political successes come at the cost of meeting peoples' 'real needs.' By pressing for the inclusion of sexual and reproductive health and rights in development debates and outcome documents, say 'pro-family' activists, feminists ignore issues like nutrition, sanitation and literacy. In this way, feminist NGOs involved in the UN are depicted as powerful bullies, who do not listen to the needs and desires of women in poor countries, and harass conservative NGOs who seek to offer alternative perspectives.

Feminists are accused of being ideologues who pursue their agenda regardless of the realities of poor women. In many texts, feminism is linked with other political ideologies condemned by 'pro-family' organisations. Some 'pro-family' perspectives see feminists using Marxist ideas to bring down the 'natural family,' whilst others stress the liberal capitalist interests working in conjunction with feminist NGOs to bring about a more self-serving, individualistic, consumer-driven society. Still others see feminism combining with a radicalised imperialist agenda that seeks to alter the very fabric of social life. Each of these characterisations is discussed in depth in the following section.

\section{Feminists are responsible for 'anti-family' changes}

The term 'radical feminism' is prolific in 'pro-family' discourse. 'Radical' is used as a prefix which separates 'bad' feminist ideas from 'good' ones. Though it sometimes refers to particular feminist philosophies of patriarchy and oppression, 'radical' is more commonly used to marginalise a variety of different kinds of feminist arguments. The term 'radical' is frequently found as a prefix to feminism in 'pro-family' texts, and appears to be interchangeable with 'gender' feminism.

\footnotetext{
7 'Militant' and 'extreme' feminism are also common, and serve the same purpose.
} 
As a brief illustration of the wide use of these terms, of the articles on CWA's website that contain the term 'feminist' or 'feminism,' nearly a third also contain one or both of these qualifiers. ${ }^{8}$

'Radical' feminism, according to 'pro-family' activists, bears the blame for normalising comprehensive sex education, contraception and abortion. This, say 'pro-family' organisations, is a massive social experiment that feminists are conducting on a global scale. The 'radical' feminist experiment has 'sex without consequences' as its end goal. In this view, 'radical' NGOs who press for this goal through their advocacy for sexual and reproductive rights have no genuine interest in the real needs and desires of women. 'Radical' feminism is portrayed as distorted and unnatural and leads to acceptance of (and conversion to) homosexuality. This comes about because 'radical' feminists' seek to meddle with nature and remove all vestiges of 'traditional masculinity.' From this perspective, 'pro-family' organisations see themselves as having knowledge of the 'real' agenda of 'radical' feminists and the ability to protect the world from their machinations.

'Radical' is used in opposition to a set of feminist arguments which 'pro-family' groups find reasonable, such as political and civil rights won by first wave feminists. These prefixes also protect 'pro-family' leaders from association with their ideological opponents when they speak about themselves as feminists or 'prowoman. ${ }^{9} \mathrm{CWA}$, for example, supports the empowerment of women, but derides the pursuit of 'sameness in the name of equality. ${ }^{10}$ In this way, a 'pro-family' feminism emerges - what its proponents call an 'authentic' feminism that celebrates difference, appreciates the constraints of human nature and ascribes to 'gender complementarity' - and can be rescued from its association with 'radical' feminism.

\footnotetext{
${ }^{8}$ A search for articles containing the terms 'feminism' or' feminist' on www.cwfa.org [on 02/04/08] elicited 1555 items on CWA's website, while the terms 'radical feminism' and 'radical feminist' resulted in 306 items retrieved. Add 'gender' in the same way to this search and the number of articles rises to 489 .

${ }^{9}$ Consider the following quote from a lobbyist in a CWA article: 'I consider myself a feminist, but I'm a true feminist. I'm for women, and so that's why I'm here, because I'm pro-woman, and I don't think abortion is pro-woman.' McGinnis, E. (2005) 'REAL Women's Lobbying Day Succeeds on Capitol Hill,' Concerned Women for America, 29 April 2005. Available at http://www.cwfa.org/articles/8015/CWA/life/index.htm [last accessed 24/08/09].

${ }^{10}$ Knight, R. (2003) 'Turning Women into Cannon Fodder,' Concerned Women for America, 29 April, 2003. Available at http://www.cwfa.org/articles/3708/CFI/cfreport/index.htm [last accessed 26/08/09].
} 
As has been discussed by other observers of the Christian Right, 'pro-family' elites seek to 'return' feminism to its 'pro-life' origins. One HLI author writes that during a lecture in Goa, he 'spoke of women's empowerment - how it started beautifully, and how it was and is being ruined by radical feminists. ${ }^{11}$ According to CWA, this is because feminism has 'gone the wrong way, baby. ${ }^{12}$ Arguing that feminism has lost sight of the real needs and desires of women, Crouse suggests that the majority of American women find the term 'feminist' offensive. ${ }^{13}$ 'Experts agree,' writes Crouse, 'that women are growing more and more uncomfortable with the current feminist movement. ${ }^{14}$

Capitalising on this discomfort, Crouse and LaHaye seek to reinvent feminism in the form of the conservative Christian woman. In A Counterfeit Strength, the pair write that 'radical feminists did not invent the idea of the powerful woman. God did. ${ }^{15}$ As LaHaye and Crouse see it, great women are also humble, faithful and obedient, and true power is found through God. The authors contrast this kind of strength with feminist's struggle for equality in other, more public, areas. 'Radical' feminists, in CWA's view, in seeking power through their careers, their relationships and through the acquisition of money, do not actually come any closer to fulfilment or equality with men. ${ }^{16}$

Focus on the Family takes a similar line, isolating 'pro-family' feminism from its 'anti-family' contemporaries. Highlighting the anti-abortion stance of 'Susan B. Anthony: pro-life feminist' one Focus author offers a number of contemporary

\footnotetext{
${ }^{11}$ Human Life International (2008) Special Report, no. 283, July 2008, p. 6. Accessed at http://www.hli.org/sr_jul 08.pdf [Last accessed 30/01/07].

${ }^{12}$ Crouse, J. S. (2003) 'Crouse delivers speech at Princeton: a conservative critique of feminism,' Concerned Women for America, 8 October 2003. Available at http://www.cwfa.org/articles/4693/BLI/media/index.htm [last accessed 24/08/09].

${ }^{13}$ Crouse summarises a 2004 CBS poll in which 'three out of four women described the word feminist as an insult.' Crouse, J. (2004) 'Feminism and the Family,' Remarks at the World Congress of Families III, Mexico City. Concerned Women for America, 29 March, 2004. Available at http://www.cwfa.org/articles/5435/BLI/commentary/in dex.htm [last accessed 24/08/09].

${ }^{14}$ Ibid.

${ }^{15}$ Crouse, J. S. and B. La Haye, (2001), 'A Counterfeit Strength,' Family Voice, September/October 2001, Concerned Women for America. Available at http://www.cwfa.org/familyvoice/2001-09/2226.asp [last accessed 24/08/09].

${ }^{\frac{26}{16} \text { Ibid. }}$
} 
examples of feminists who have opposed abortion. ${ }^{17}$ The era of 'pro-life' feminists is not in the past, stresses the author; there are still numerous feminists who condemn abortion as harmful to women.

Dobson himself suggests that feminism was once a beneficial force, with 'legitimate grievances, such as equal pay for equal work and discrimination in the workplace. ${ }^{18}$ According to Dobson, however, feminism went far beyond these injustices, to the point where we are at now, in which 'radical feminists and elitists tell us that men are fools and boys are fools too. ${ }^{19}$ Another Focus commentator sums the distinction within feminism succinctly: 'Authentic feminism,' she suggests, 'celebrates the dignity of women ... radical feminism refuses to acknowledge differences between men and women, idealizes androgyny and denigrates marriage and motherhood. ${ }^{20}$

C-Fam is even clearer about the difference between 'radical' feminists and their acceptable counterparts. As an explanation, C-Fam author Douglas Sylva suggests that the term 'radical feminist' distinguishes feminists who condone abortion, and understand gender as a social construct, from other types of feminism. ${ }^{21}$ Abortion and homosexuality, as ever, remain the most important issues on the political horizon for 'pro-family' groups.

Feminism is often depicted as a form of Marxism that pits men and women against each other. 'Pro-family' authors associate Marxist concepts of conflict with feminism in a number of different ways. For the FRC, Patrick Fagan and others write that marriage is the key distinction between feminism that is unacceptable, and 'moderate, mainstream' feminism. The latter kind, suggest the authors, 'have

\footnotetext{
${ }^{17}$ Mathewes-Green, F. (2000) 'Susan B. Anthony: pro-life feminist,' Focus on the Family, January 2000. Available at http://www2.focusonthefamily.com/focusmagazine/sohl/A000000164.cfm [last accessed 24/08/09].

${ }^{18}$ Dobson, J. C. (2004) 'Radical Feminism Shortchanges Boys: Dr Dobson Considers the feminist movement's affect [sic] on boys and shares an excerpt from Bringing up Boys,' Focus on the Family, November 2004. Available at http://www2.focusonthefamily.com/docstudy/newsletters/A000000370.cfm [last accessed 01/06/09]. ${ }^{19}$ Ibid.

${ }^{20}$ Campbell, C. C. (2005) quoted in Culture Clips, September 18, 2005, Focus on the Family, available at http://www.pluggedinonline.com/cultureclips2/a0002330.cfm [last accessed 01/06/09]. ${ }^{21}$ Sylva, D. (2003) 'The United Nations Children's Fund: Women or Children First? International Organisations Research Group,' Catholic Family and Human Rights Institute White Paper, p. 1. See https://www.c-fam.org/docLib/20080424_Number_3 UNICEF_2003.pdf [last accessed 20/08/09].
} 
long rejected [the] animus against marriage ... and are focused on a worthy concern: removing obstacles to the advancement of women in all walks of life.' 'Radical' feminists, by contrast, go far beyond this: According to Fagan et al., 'radical' feminists 'seek to undermine the nuclear family of married father, mother, and children, which they label the "patriarchal family.", 22 The 'radical' feminist vision of marriage, in the words of these authors, is 'man's war against women.' In the author's view, this vision explains the 'shrillness' of feminist opposition to policies that promote 'healthy marriage.' 23

In a 2005 article, CWA links feminist efforts to the communist consolidation of power. 'Make no mistake,' she warns:

'like Lenin who talked idealistically about the Communist state "withering away" while he was ruthlessly consolidating his tyrannical control over the people of Russia, these so-called "advocates for women's rights" are really about gaining the power to dictate how societies all over the world will organize and rule. ${ }^{24}$

Crouse still sees feminists as implicated in 'globalism,' conflating their efforts to improve public health with advocacy for more government control, and eventually world government control. These feminists ('many of whom are neo-Marxists,' says Crouse) pit their utopian socialist schemes against a 'real-world' system. ${ }^{25}$ In this light, the liberation advanced by feminists in the form of sexual and reproductive rights masks their attempt to control people through the UN and its member states. HLI also picks up this theme, running courses in which Brian Clowes teaches his seminarians about 'the Marxist Roots of the Anti-Life Movement (see photograph below). ${ }^{26}$

\footnotetext{
${ }^{22}$ Fagan, P. F., R. E. Rector and L. R. Noyes (2003) 'Why Congress Should Ignore Radical Feminist Opposition to Marriage,' Family Research Council Backgrounder No. 1662, June 16, 2003, available at http://www.frc.org/get.cfm?i=LH08H41 [last accessed 01/06/09].

${ }^{23}$ Ibid.

${ }^{24}$ Crouse, J. S. (2005) 'A Contest of Wills,' Concerned Women for America, 1 March, 2005.

Available at http://www.cwfa.org/articledisplay.asp?id=7573\&department=BLI\&categoryid=nation [last accessed 24/08/09].

${ }^{25}$ Ibid.

${ }^{26}$ Human Life International (2006) 'The Death Bill,' Special Report, no. 259, July 2006, Human

Life International. Available at http://www.hli.org/sr july_06.pdf [last accessed 13/11/06].
} 


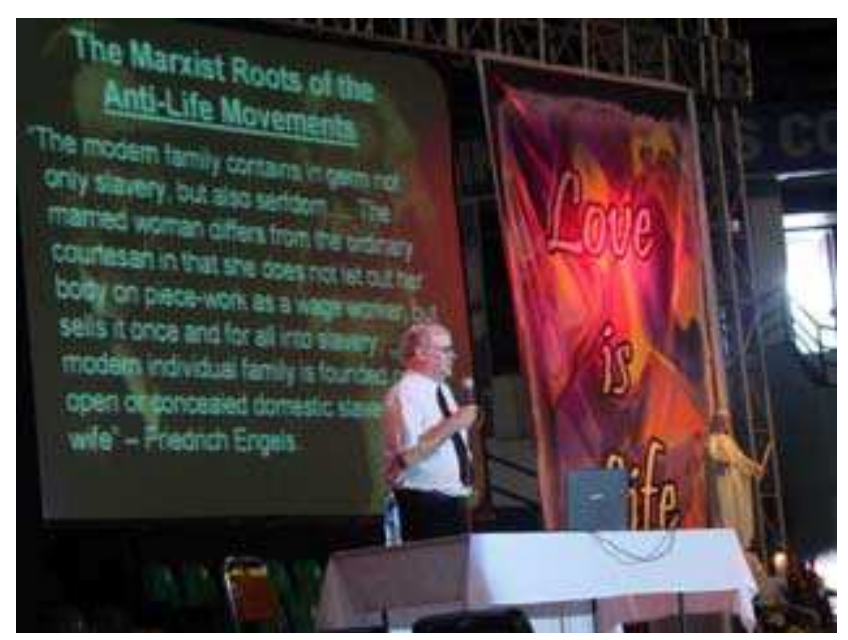

(Human Life International, 2006)

In a trip to Nicaragua, Euteneuer equates contraceptive distribution with tyranny; a 'leftist Marxist revolution called contraceptive imperialism.' 27 Though most references connecting feminism to Marxism are left unexplained in HLI texts, Euteneuer does delve deeper in a trip to Central America in 2003. He condemns 'radical feminism' as a 'plague on the family,' offering his view that it is 'the feminist face of Marxism' in which 'feminists pit man against woman as a form of class hatred within the family and it too is a struggle to the death. ${ }^{28}$

The Howard Center uses the words of self-described Marxist feminists to argue that feminism is in fact 'anti-family.' In a 2005 Religion and Society Report, one Howard Center author offers a plethora of Marxist feminist quotes showing that 'burying the family at long last,' and 'the complete destruction of traditional marriage and the nuclear family,' are the ultimate goals of 'radical' feminism. ${ }^{29}$ That these quotes have come to stand for 'the feminist agenda' in the view of 'profamily' organisations is not particularly noteworthy, however. It is not uncommon to marginalise one's political opponents by associating them with extreme forms of their ideologies. What is important to note here is the implication that it is this particular form of feminism that is seen as globally ascendant, and in control of key

\footnotetext{
${ }^{27}$ Euteneuer, T. J. (2003) 'Pro-Life Missionary Trip: Nicaragua,' 24 - 28 June 2003. Human Life International. http://www.hli.org/mission_nicaragua_2003.html [accessed 21/12/06].

${ }^{28}$ Euteneuer, T. J. (2003) 'Pro-Life Missionary Trip: Costa Rica,' 28 - 30 June 2003. Human Life International. http://www.hli.org/mission_coasta_rica_2003.html [accessed 21/12/06].

${ }^{29}$ Vivian Gornick, quoted in Heimbach, D.R. (2005) 'Deconstructing the Family,' The Religion and Society Report vol. 22, no. 7, October/November 2005. The Howard Center, available at http://www.profam.org/pub/rs/rs_2207.htm [last accessed 21/04/08].
} 
international political institutions such as the UN and the World Bank. In this appeal to oppose a massive global Marxist/feminist threat, then, the Howard Center justifies its activism on behalf of the 'natural family.'

Feminism is also depicted as a massive social experiment which promotes 'free love' with 'no consequences.' As was touched on in the previous chapter, in destroying the family, 'radical' feminists are pursuing the goal of building a 'postfamily order,' according to 'pro-family' observers. This is imagined as a grand experiment, in which feminists within the UN (and beyond it) seek absolute sexual freedom. In the 'pro-family' framework, this is the purpose of the dissemination of contraceptive technologies: 'radical' feminists seek to reduce the body to a consequence-free play area, dedicated to the pursuit of enjoyment.

Austin Ruse, for example, suggested in 1998 that 'feminists believe the traditional notion of the family - father, mother, and children - must be permanently altered because it hinders the advance of complete sexual and reproductive freedom. ${ }^{30}$ Crouse, for her part, sees 'free love' - which she defines as 'sexual activity that is unconstrained and without consequences' - as the central aspect of the women's liberation movement. ${ }^{31}$ Normal women find 'modern feminism' problematic suggests Crouse, because it 'ignores the relationship between decisions/choices and consequences. $^{32}$

In this reading, feminists' advocacy for reproductive and sexual rights is an appeal to people's desire to gratify themselves, encouraging dangerous and selfish behaviour and ultimately leading to the 'radical' feminist's end goal: the destruction of the family. For 'pro-family' organisations, then, their job is to defend the threatened moral fortitude and traditions of developing countries from the

\footnotetext{
${ }^{30}$ Ruse, A. (1998) 'New Session of the UN General Assembly Begins Work in New York City,' Friday Fax, September 11, 1998 vol. 1, no. 48, Catholic Family and Human Rights Institute, available at http://www.c-fam.org/publications/id.57/pub_detail.asp [last accessed 24/08/09]. ${ }^{31}$ Crouse, J. (2004) 'Feminism and the Family,' Remarks at the World Congress of Families III, Mexico City, March 29, 2004. Concerned Women for America, http://www.cwfa.org/articles/5435/BLI/comm entary/index.htm [last accessed 13/3/08].

${ }^{32}$ Crouse, J. S. (2003) 'Crouse delivers speech at Princeton: a conservative critique of feminism,' Concerned Women for America, October 2003. Available at http://www.cwfa.org/articledisplay.asp?id=4693\&department=BLI\&categoryid=media [last accessed 24/08/09].
} 
hedonistic and corrupting effect of feminists and their ideas. HLI is one such organisation, painting itself as defending the world against what it calls a 'feminist onslaught. ${ }^{33}$ Feminist NGOs appear in HLI texts as 'armies of well-financed liars, 34 'loaded with money, ${ }^{35}$ who 'wield millions of dollars and exist for the singular purpose of pushing their own hedonistic agendas on the rest of the world. ${ }^{36}$ HLI declares its resistance to what it calls the "militant atheistic feminist movement. ${ }^{37}$ Euteneuer writes that feminists enjoy 'perverse glee' when they enter countries in order to 'undermine and destroy the fabric' of societies. ${ }^{38}$ Chief among the 'pro-death' ${ }^{39}$ feminist NGOs in Euteneuer's view is Planned Parenthood, which 'prowls about like a roaring lion looking for someone to devour. ${ }^{40}$ Representations of feminist NGOs moving into developing countries and corrupting the innocent are frequently used in appeals for financial support for HLI's global activism.

One of the main 'pro-family' complaints about feminists is that they push policies that poor countries do not need or want. 'Pro-family' groups cite the legalisation or legitimisation of prostitution, abortion and homosexuality as the most problematic of the policies that feminist NGOs are trying to force developing countries to accept. 'Pro-family' organisations see developing countries as helpless to oppose the liberalisation of their laws because feminists have managed to make

\footnotetext{
${ }^{33}$ Euteneuer, T. J. (2003) 'Pro-Life Missionary Trip: Nicaragua,' 24 - 28 June 2003. Human Life International, http://www.hli.org/mission_nicaragua_2003.html [21/12/06].

${ }^{34}$ Euteneuer, T. J. (2002) 'Pro-Life Missionary Trip: Peru,' $10-14$ June 2002. Human Life International, http://www.hli.org/mission_peru_2002.html [accessed 30/01/07].

${ }^{35}$ Euteneuer, T. J. (2003) 'Pro-Life Missionary Trip: El Salvador' 28 - 30 June 2003. Human Life International, http://www.hli.org/mission_el_salvador_2003.html [accessed 21/12/06].

${ }^{36}$ Euteneuer, T. J. (2003) 'Fighting the Global De-Population Movement,' Humanae Vitae 35th Anniversary Conference, Sydney, Australia, July 25, 2003. http://www.hli.org/commentaries_fr_tom_population_control_fighting_global_pop.html [13/11/07].

${ }^{37}$ Euteneuer, T.J.(2004) 'Pro-Life Missionary Trip: Venezuela,' 29 April - 30 June 2004. Human Life International, http://www.hli.org/mission_venezuela_2004.html [accessed 21/12/06].

${ }^{38}$ Euteneuer, T.J. (2002) 'Pro-Life Missionary Trip: Paraguay.' Human Life International, 14 June, 2002, accessed at http://www.hli.org/mission_paraguay 2002.html [accessed 21/12/06].

${ }^{39}$ Euteneuer, T.J. (2002) 'Pro-Life Missionary Trip: Tanzania,' 22 August - 1 September 2002. Human Life International, http://www.hli.org/mission tanzania_2002.html [accessed 17/11/06]. ${ }^{40}$ Euteneuer, T.J. (2004) 'Pro-Life Missionary Trip: Venezuela,' 29 April - 30 June 2004. Human Life International, http://www.hli.org/mission_venezuela_2004.html [accessed 21/12/06]. In Paraguay, for example, Euteneuer depicts the situation as follows: 'The feminists have been infiltrating the political process since before the Cairo conference on women in 1994, and the proliferation of radical feminist, non-governmental organizations in Paraguay has been literally exponential. Feminists everywhere just try to force their agendas into the political mainstream by overwhelming the process with their sheer number and with a saturation of their nefarious ideas that are readily parroted by the liberal media.' Euteneuer, T.J. (2002) 'Pro-Life Missionary Trip:

Paraguay,' 14 June 2002, Human Life International, http://www.hli.org/mission_paraguay_2002.html [21/12/06].
} 
development assistance and funding for health services conditional on the adoption of liberal norms surrounding sexuality and reproduction.

In a 2003 article, CWA is concerned that HIV prevention funds would be made available to groups that advocate for the legalisation of prostitution. Giving condoms to prostitutes, in this organisation's view, 'would be like placing a Bandaid on a cancer patient: what these women need is bold assistance to help them out of prostitution. ${ }^{41} \mathrm{CWA}$ sees prostitution as a trap (frequently equated with human trafficking) rather than a choice. In this way, feminists are depicted as disregarding prostitutes' desperation to escape their situations, and in fact increasing and prolonging the suffering of women.

Feminists are accused of the 'promotion of a victim status' for women in a number of 'pro-family' texts, especially by CWA activists. 'Pro-family' activists see men as the chief beneficiaries of reproductive rights. One CWA author argues that the feminist pursuit of reproductive rights has increased the victimisation of women because it

'has more ironically benefited men who no longer bear responsibilities for impregnating girlfriends as long as there's a women's clinic handy. Women may have more power and clout in the boardroom but not over their lives. ${ }^{42}$

This position is also broadly shared by other 'pro-family' groups. In 2006, Carlson writes that 'frequently, boyfriends or male family members pressure women into having abortions. ${ }^{43}$ Thus reproductive rights are portrayed as a means of increasing the suffering of women, rather than empowering them.

\footnotetext{
${ }^{41}$ Vineyard, A. (2003) 'AIDS Funding: A Good Idea Gone Miserably Bad? Abstinence takes a back seat to condoms,' Concerned Women for America, 31 March 2003, available at http://www.cwfa.org/articles/3645/BLI/femfacts/index.htm [last accessed 24/08/09].

${ }^{42}$ Colon, A. (2000) 'We need a new Women's Movement.....Now!' Concerned Women for America, 12 December, 2000,

http://www.cwfa.org/articledisplay.asp?id=1105\&department=CWA\&categoryid=family [31/03/08]. See also, CWA (2004) 'A Christian Women's Declaration,' Concerned Women for America, 8 March, 2004. Available at http://www.cwfa.org/articles/5338/CWA/misc/index.htm [last accessed 26/08/09].

${ }^{43}$ Carlson, A. (2006) 'World Congress of Families Cautions Poland Against Legalizing Abortion,' The World Congress of Families Press Release, the Howard Center, 10 July, 2006. Available at http://profam.org/press/wcf.pr.060710.htm [last accessed 26/08/09].
} 
This concern is transferred to women in developing countries in 'pro-family' texts with vigour. Contraceptive technologies have had a devastating effect in areas where women enjoy very limited decision-making autonomy, say 'pro-family' organisations. They offer a number of historical examples of how women are victimised by contraceptive technologies, most notably in the coercion of women by their governments in the name of fertility reduction targets. This form of abuse which also concerns many feminists - has received considerable attention in "profamily' discourse. For their part, however, 'pro-family' organisations blame sexual and reproductive rights language for providing window dressing for this form of abuse.

Similarly, "pro-family' activists are deeply concerned at the degree to which economic pressures may result in abortion where it is available, stressing that in these situations, access to abortion actually reduces the status of women. ${ }^{44}$ The 'pro-family' view of women's bodies sees them as fundamentally inviolable or sacred. However, the presence of contraceptives and abortion renders these bodies vulnerable to economic forces which have no regard for their sacred status. This economic pressure to prevent or terminate pregnancies may come from forces external to the family, or may come within it; like some feminists, 'pro-family' organisations are concerned that reproductive health services actually victimise women because of their relative powerlessness within their relationships.

'Pro-family' organisations occasionally argue that feminists are cultural imperialists. ${ }^{45}$ Western feminists are accused of holding up progress on development because they refuse to omit liberal terms and passages from international agreements. One CWA flyer distributed at the UN - despite the activities of what CWA describes as 'members of a lesbian caucus, [who] tried to stop the distribution' - informed delegates that 'if the West would stop pushing

\footnotetext{
${ }^{44}$ As some feminists have been careful to warn proponents of reproductive rights, Ken Blackwell suggests that in many contexts, cultural and economic pressures make the decision to have an abortion a spurious choice. Blackwell, K. (2007) 'Protecting the Human Dignity of the Girl Child Worldwide,' Family Research Council. Available at http://www.frc.org/get.cfm?i=PV08L11 [last accessed 26/08/09].

${ }^{45}$ CWA (2002) 'Beijing+5-Pro-Life, Pro-Family Coalition Wins Big at Beijing+5' Concerned Women for America, 1 January 2002, available at http://www.cwfa.org/articles/1922/CWA/nation/index.htm [last accessed 26/08/09].
} 
homosexual and abortion "rights" on unwilling countries, the document would be done.' It continues: 'Don't blame the developing countries for the courage to defend their values and their right to self-government. ${ }^{46}$

Ruse also depicts feminists as contemptuous of the political process in their efforts to exert their influence on the policies of developing countries. Labelling his opponents as 'aggressive radical feminist NGOs, ${ }^{47}$ Ruse suggests that Western feminists amuse themselves by 'openly laughing' at developing country delegates who do not speak English as a first language. 'In fact,' suggests Ruse, 'radical social activists at the UN count on this confusion to intrude their extreme agendas into documents.' 48

In a 2006 Friday Fax, C-Fam accuses feminist NGOs of seeking to build a global network of 'supranational tribunals' that will implement their agenda, 'bypass[ing] representative government and national sovereignty. ${ }^{, 49}$ Europe is a major part of the feminist threat in C-Fam texts, with the European Union portrayed as a domineering bully, disregarding the desires of developing countries. One Friday Fax in 1999 states that

'When the G-77 tried to change only one word in the "women and health" section, the German chairman of the general session, supported vociferously by the powerful EU, tersely instructed the G-77 nations that they must abide by the agreement. ${ }^{50}$

\footnotetext{
${ }^{46}$ CWA (2000) 'CWA Presents Petition Upholding the Home, Marriage and Family to Ambassador Linda Tarr-Whelan,' Concerned Women for America, 6 August 2000, available at http://www.cwfa.org/articles/1917/CWA/nation/index.htm [last accessed 01/06/09].

${ }^{47}$ Ruse, A. (1999) 'Overreaching by US and EU Angers Developing World, Stalls Cairo+5,' Catholic Family and Human Rights Institute Friday Fax, April 9, 1999, vol. 2, no. 23, available http://www.c-fam.org/publications/id.86/pub_detail.asp [last accessed 24/08/09].

${ }^{48}$ Ruse, A. (1999) 'UN Double Standard Favors Western Nations Against Developing World,' Catholic Family and Human Rights Institute Friday Fax, March 19, 1999, vol. 2, no. 21. See http://www.c-fam.org/publications/id.83/pub_detail.asp [last accessed 24/08/09].

${ }^{49}$ Yoshihara, S. (2006) 'Left and Right Agree, UN Compliance Committees New Front Line in UN Abortion Debate,' Catholic Family and Human Rights Institute Friday Fax, September 29, 2006, vol. 9, no. 41. Available http://www.c-fam.org/publications/id.480/pub_detail.asp [last accessed 24/08/09]. See also Ruse, A. (2002) 'UNFPA Executive Director seeks additional funding for beleaguered agency,' Catholic Family and Human Rights Institute Friday Fax, March 22, 2002, vol. 5, no. 13, http://www.c-fam.org/publications/id.83/pub_detail.asp [last accessed 24/08/09].

${ }^{50}$ Ruse, A. (1999) 'UN Double Standard Favors Western Nations Against Developing World,'

Friday Fax, March 19, 1999, vol. 2, no. 21. See http://www.c-

fam.org/publications/id.83/pub_detail.asp [last accessed 24/08/09].
} 
Seeing feminists as pushing their unwanted agenda on increasingly frustrated developing countries rather than helping them, C-Fam calls on 'pro-family' organisations to rally against feminism at the global level.

Smaller European countries which oppose the liberalisation of homosexuality and abortion laws must also be protected from feminists within the EU in 'pro-family' discourse. 'Pro-family' organisations appeal to choice and diversity in their support for the conservative stances of small countries. In one example, on the Latvian government's conservative stance on homosexuality, Carlson praises its decision 'not to be bullied into acquiescing to the New Erotic Order.' Carlson calls on the EU 'to accept diversity of values among its members. ${ }^{51}$ Similarly, entering the Portuguese abortion debate, Carlson criticises the 'European Bureaucracy' for 'eradicating choice among nations, when it comes to protecting the unborn child., 52

All kinds of feminism (except 'pro-family' feminism) are seen as part of a slippery slope in 'pro-family' discourse. Acceptance of 'even the tiniest portion of the antilife agenda,' says Euteneuer, 'is invariably fatal to a nation's soul and well-being. ${ }^{, 53}$ Commonly, 'pro-family' leaders see the work of feminists as a kind of social engineering that attempts to homogenise men and women through interference in the upbringing of children. In this effort, feminists are messing with human nature, say 'pro-family' activists. As Carlson puts it,

'women and men are hardwired to be different. Denying these differences can only result in violations of human nature, doing particular harm to existing and potential children. ${ }^{54}$

\footnotetext{
${ }^{51}$ The Howard Center (2006) 'World Congress of Families Supports Latvian Decision to Withhold Special Rights from Homosexuals,' World Congress of Families Press Release, 26 June, 2006, available at http://www.profam.org/press/wcf.pr.060626.htm [last accessed 24/08/09].

${ }^{52}$ Carlson, A. (2006) 'World Congress of Families Cautions Portugal Against Legalizing Abortion,' The World Congress of Families Press Release, 10 July 2006, available at http://profam.org /press/wcf.pr.060710.htm [last accessed 30/10/06].

${ }^{53}$ Human Life International (2006) Special Report, no. 259, July 2006, p. 2. See http://www.hli.org/sr_july_06.pdf [13/11/06] (Emphasis in original).

${ }^{54}$ Carlson, A. (2005) 'Sweden and the failure of European Family Policy,' The Howard Center, A lecture for the Civics Institute, the Senate Building, Prague, Czech Republic, 27 April, 2005. Available at www.profam.org/docs/acc/thc.acc.prague 050427.htm [last accessed 08/09/09].
} 
In this view, feminist promotion of gender equality denies or minimises the differences between men and women; feminism is not only distorted and unnatural, it is part of a slippery slope towards homosexuality.

'Pro-family' groups are divided as to whether nature is strong enough to endure these violations, or whether over time, feminists will achieve their supposed goal of a homogenised social order. Discussing UNFPA, Fagan (this time for C-Fam) confirms that feminists within the organisation are conducting an 'experiment in playing god - against the natural order, which will not change, no matter what advances man makes. ${ }^{55}$ In this framework, the 'natural order' is strong enough to resist the 'feminist ideologues' who wish to 're-engineer human nature. ${ }^{56}$

In other 'pro-family' texts, human nature is not so resilient. Reacting to the 'feminist' idea that 'kids need fathers like fish need bicycles,' Dobson argues

'feminists have 'sniffed out' male pride and uprooted it and the result is that men don't know how to be responsible grown-ups anymore. Without the influence of a father or other responsible male role model ... disastrous consequences - such as homosexuality - may follow. ${ }^{57}$

The 'natural order' is thus not always seen as strong enough to prevent feminists from achieving their goals, in this case, the destruction of the family and the conversion of heterosexual children to homosexuality.

In some texts, HLI sees feminism as so unnatural that it is easy for societies steeped in 'traditional' and 'natural' values to shrug off feminist initiatives as the bizarre ideas of an alien culture. But in others, feminists are 'prowling lions,' and the people they infect with their 'corrupt' agenda are poor, simple and vulnerable to feminist ideas. In one case, feminist ideas are seen as 'programming.' In Peru,

\footnotetext{
${ }^{55}$ Fagan, P. in Sylva, D. A. (2002) 'The United Nations Population Fund: Assault on the World's Peoples,' Catholic Family and Human Rights Institute, The International Organisations Research Group, White Paper Series Number Three, p. III. Available via http://www.cfam.org/publications/id.327/pub_detail.asp [last accessed 20/08/09].

${ }^{56}$ Carlson, A. (2005) 'Sweden and the failure of European Family Policy,' The Howard Center, A lecture for the Civics Institute, the Senate Building, Prague, Czech Republic, 27 April, 2005. Available at www.profam.org/docs/acc/thc.acc.prague050427.htm [last accessed 08/09/09]. ${ }^{57}$ Dobson, J. C. (2004) 'Radical feminism shortchanges boys,' Focus on the Family, November 2004. available at http://www2.focusonthefamily.com/docstudy/newsletters/A000000370.cfm [last accessed 24/08/09].
} 
Euteneuer is pleased to report the successful teaching of 'natural family planning' to rural couples. 'Rural couples are the easiest to teach,' he says, 'because they don't come pre-programmed against the message of NFP by the media-controlled culture. ${ }^{58}$ As was discussed in chapter three, there is hope for HLI, because 'shame,' and 'embedded, authentic cultural values' make people reluctant to embrace feminist ideas. Yet they are still considered dangerous.

In a 'pro-life missionary trip' to Costa Rica, Euteneuer accuses feminists of portraying 'the natural roles specific to their gender' as 'forms of social repression that men have used for ages to keep women subjugated to them. ${ }^{59}$ In Euteneuer's view, this is intimately connected to homosexuality. He continues his discussion on the feminist influence in Latin America by noting that he is not surprised that with this 'rabid leftist-feminist ideology being pumped into Hispanic societies, there is a rapid growth of homosexuality.' ${ }^{60}$ In this reading of the situation, 'natural' or 'traditional' repulsion of feminism and homosexuality is not always enough; acceptance of one leads to the other.

CWA also links feminism to homosexuality, as part of a continuum. In her historical critique of feminism, Crouse suggests that the feminist movement began to fall apart when some feminists started to advocate for the unhindered expression of sexual desire, and it completely came unglued when it began to focus so intensely on promoting lesbianism. ${ }^{61}$ That homosexuality (and lesbianism in particular) is an end result of feminism is a virtual truism in most 'pro-family' discourse. This is framed in a number of ways. In some 'pro-family' texts, tolerance of feminist ideas leads to tolerance of homosexuality in a broad sense. A 2005

\footnotetext{
${ }^{58}$ Euteneuer, T. J. (2002) 'Pro-life Missionary Trip: Peru,' Human Life International, 14 June, 2002. Accessed at http://www.hli.org/mission_peru_2002.html [last accessed 21/12/06].

${ }^{59}$ Euteneuer, T. J. (2003) 'Pro-life Missionary Trip: Costa Rica.' Human Life International, 30 June 2003. Accessed at http://www.hli.org/mission_coasta_rica_2003.html [last accessed 21/12/06]. ${ }^{60}$ Ibid.

${ }^{61}$ Crouse, J. S. (2004) 'Feminism and the Family,' Remarks to the World Congress of Families, Mexico City, 29 March, 2004. Concerned Women for America, available at http://www.cwfa.org/articles/5435/BLI/commentary/index.htm [last accessed 24/08/09].
} 
Religion and Society Report reminds its readers that 'the ordination of women has been followed in several cases by the acceptance of homosexuals in the ministry. ${ }^{62}$

Alternatively, feminism leads to 'conversion' to homosexuality at an individual level too. A 2001 Religion and Society Report makes the case that if sex roles are constructed and can be changed, then homosexuality is also the result of cultural construction and can be changed. Moreover, the argument goes, gay pride activities 'may condition people not otherwise so inclined or determined to become homosexuals. ${ }^{63}$ Thus it is inferred that feminists and homosexuals intend to reconstruct people's gender identities in their own image. Feminist efforts to brand gender as a construct, then, are an attack on the heterosexual identity of children, and thus an assault on the 'natural family.'

In all of these different characterisations, feminists are seen as powerful agents promoting their own agenda. This agenda does coincide with the goals of other organisations, but feminists are granted at least a degree of ambition and influence. In the characterisations that follow, feminists may have some agency, but they and their ideas are not the real enemy that 'pro-family' organisations face. Feminism is the product of (or the facade for) some other force: but what?

\section{There is already a problem with modern society, and feminism is just a symptom}

In the second type of characterisation, in which feminism is just a symptom of some other malevolent 'anti-family' force or forces, there are a number of other 'antifamily' agents and ideas offered as the real problem. In many 'pro-family' texts, the cultural elevation of self-gratification and consumerism is depicted as leading to feminism and homosexuality, not the other way around. The alleged devaluation of motherhood is part of this problem, in which selfishness in modern industrialised society is connected to the desire of young people to pursue careers and postpone or forgo family life. The mother, say ‘pro-family' leaders, has been lost as a symbol

\footnotetext{
${ }^{62}$ Berthoud, J. M. (2005) 'The Family in Theological Perspective,' the Religion and Society Report, vol. 22, no. 2, The Howard Center http://www.profam.org/pub/rs/rs_2202.htm?search [last accessed 25/08/09].

${ }^{63}$ The Howard Center (2001) 'In Addition to Which,' the Religion and Society Report, vol. 18, no. 6, June, 2001. See http://www.profam.org/pub/rs/rs 1806.htm [last accessed 25/08/09].
} 
and role model of selflessness, and this places society in a vicious cycle in which individualism and materialism sustain 'anti-family' outcomes, and vice versa.

In this view, women from developing countries need to be protected from feminists because they encourage self-serving individualism - in the form of demanding their rights - as an antidote to patriarchy. 'Demographic Winter,' a 'pro-family' framework discussed at length in the following chapter, is the end result of this kind of individualism. Secularism is also responsible for declining fertility, blamed alongside feminism for the 'birth dearth' in the developed countries which have turned their back on religion. In one 'pro-family' text, industrialisation and modernity are to blame for feminism. Finally, some 'pro-family' intellectuals see feminism as a small part of a larger relativising phenomenon, which is a far bigger problem than feminism because it trivialises religion and questions the very existence of God. The next part of this chapter describes these issues in detail.

There are a number of 'pro-family' texts which see feminism as a product of selfishness. Materialism bears a lot of the blame for the problems faced by families, in Carlson's view. He identifies advertising as a means of destroying the family economy. By stimulating the desire for more manufactured products, he argues, consumerism works to export family members from the home into the paid labour force. $^{64}$ Echoing many critics of capitalism who have gone before him, Carlson bemoans the standard measures of economic growth, which he argues have come to rely on 'the steady transfer of ever more tasks from the uncounted household economy to the fully accounted industrial orbit. ${ }^{65}$

In a lecture in 2005, Carlson expands further on this:

'Working mothers are also a great short-term boon to the economy. In place of home cooked meals, these households now buy fast food. Instead of the home care of small children, they buy day care. The negative effects of these changes on children-in forms of physical and emotional health-only show up in the long run. These

\footnotetext{
${ }^{64}$ Carlson, A. (2002) 'Love Is Not Enough: Toward the Recovery of a Family Economics,' Witherspoon Lecture, 28 June, 2002. The Howard Center/Family Research Council, available at http://www.profam.org/docs/acc/thc acc frc love_020628.htm [last accessed 25/08/09].

${ }^{65}$ Ibid.
} 
examples do point to a common rule: as families lose functions, the Gross National Product goes up...for a time. ${ }^{66}$

In this article, Carlson suggests that families need protection from three main sources of intrusion: the centralising state; modernity; and 'anti-family' ideologies (of which feminism is one). Carlson highlights working mothers, day care and 'marriage penalties' in the tax code as evidence that business-friendly policies are not necessarily 'family-friendly.' 'Capitalism itself,' concludes Carlson 'needs true "family friendly" policy to protect its own long term interests. ${ }^{67}$ In this view, rather than emancipating women, feminist successes simply provide more fodder for the market.

Carlson is treading a path that many feminists have walked before him, and defends his position in a lecture in the same year by declaring that 'Christian Democracy has formally opposed economic materialism, in both its socialist and liberal capitalist manifestations. ${ }^{68}$ That Carlson connects economic materialism in the Marxist sense with the capitalist impulse towards consumption, and disregards both options, is a part of his search for an alternative to materialist way of thinking about social change. In its place, Carlson offers tenets of Christian Democracy - churchrun health, education and welfare, for example - as a guide for successful political and economic change. Christian Democrats from across the spectrum, writes Carlson, believe that the

'spontaneous, organic structures of human life - villages, towns, neighbourhoods, labour associations, and (above all) families - need protection from the levelling tendencies of modern life. ${ }^{69}$

In addition to his desire to protect human institutions beyond the family (even unions) Carlson attacks individualism, in the name of protecting the variety of social groups. Abortion and contraception, to expand on Carlson's metaphor, are

\footnotetext{
${ }^{66}$ Carlson, A. C. (2005) 'Defining Family Friendly,' Remarks for a public dialogue co-sponsored by the Hinkley Institute of Politics, The University of Utah, 23 September, 2005. The Howard Center, available at http://www.profam.org/docs/acc/thc.acc.dfu.050923.htm [last accessed 25/08/09]. ${ }^{67}$ Ibid.

${ }^{68}$ Carlson, A. (2005) 'Europe and the Christian Democracy Movement: A Once and Future Hope?' A lecture to the Witherspoon Fellowship, The Howard Center/Family Research Council, Washington DC, 20 July 2005. Available at http://www.profam.org/docs/acc/thc_acc_frc.Christian.Democracy.htm [last accessed 25/08/09]. ${ }^{69}$ Ibid.
} 
steamrollers of modern life, in the sense that they attempt to make adjustments to flatten out even the biological differences that prevent the realisation of parity between the sexes. In order to combat the advance of 'the culture of death, institutionalized egoism, and population decline, ${ }^{70}$ Carlson pins his hopes on Christian family life, which he believes acts as a guarantor against both mass conformity and individual selfishness.

Carlson's opposition to individualism is at the root of his aversion to the world order he sees being promoted by feminists and development policymakers at the UN. Claiming the 'natural' family as 'the one anarchist institution' that is able to withstand the repressive capabilities of the modern state, Carlson fears for the family's survival against what he calls

"the "soft" totalitarianism of the early twenty-first century, now packaged around a militant secular individualism, but still seeking to build a marriage-free, post-family order. $^{, 71}$

That he pits himself so firmly against individualism helps to explain why his organisation, and indeed the 'pro-family' movement as a whole, so abhors the (individually held) human rights agenda advanced by feminist proponents of sexual and reproductive rights.

In Carlson's view, then, reproductive rights are a result of a drift towards secular individualism, or they are at least complementary social forces. Contraception and abortion grant people the ability to prevent the formation of families. This, in Carlson's view, means that individuals will no longer appreciate the essential worth of self-sacrifice, which being in a family imparts. In a fully contracepted and family-free world (which Carlson imagines is desired by feminists) the responsibility for making people act in the best interest of others then falls on society, or worse, the state. This is an outcome he finds vile. In this way, Carlson justifies his strong anti-liberal stance, putting the 'natural family' - and not the

\footnotetext{
${ }^{70}$ Ibid.

${ }^{71}$ Carlson, A. (2004) 'Standing for Liberty: Marriage, Virtue and the Political State,' a family policy lecture to the Family Research Council, Washington DC, June 16, 2004. The Howard Center, http://www.profam.org/docs/acc/thc_acc_frc_sfl_040616.htm [last accessed 25/08/09].
} 
freedoms and capabilities of the individual man, woman or child - as the highest priority of development efforts.

Women-as-mothers represent the core of the 'natural family.' As 'pro-family' organisations see it, re-valuing motherhood is the key to reversing 'anti-family' individualism in both developed and developing countries. Mothers as role models of selflessness appear as feminine ideals in many 'pro-family' texts. In a C-Fam 'white paper,' Douglas Sylva despairs over UNICEF's 'feminist revolution,' declaring that

'In the view of feminists, a mother who subsumed her own interests to the interests of her children, a person always elevated by UNICEF as an archetype, a person to be celebrated and assisted, was now considered to be guilty of perpetuating "maledefined stereotypes." 72

Feminists, Sylva argues, see motherhood as a pigeonhole that needs to be eradicated through education. 'The mother' is under threat in 'pro-family' discourse, both figuratively, as a symbol of selflessness, and literally, thanks to contraception and abortion.

Part of the problem 'pro-family' organisations say they have with feminism is that it venerates the independent, individual woman and consequently 'devalues motherhood.' CWA texts are particularly scathing of feminism for this reason, suggesting that the kind of woman produced by feminist ideas is an 'alienated and abandoned individual. ${ }^{73}$ By contrast, according to Crouse, the WCF offers a 'different vision of female empowerment... the interconnected, socially and religiously embedded woman. ${ }^{74}$ In this fashion, 'pro-family' authors juxtapose religion and companionship with secularism and isolation, in the dichotomised forms of feminism they portray.

\footnotetext{
${ }^{72}$ Sylva, D. (2003) 'The United Nations Children’s Fund: Women or Children First? International Organisations Research Group,' Catholic Family and Human Rights Institute White Paper, p. 69. See https://www.c-fam.org/docLib/20080424_Number_3_UNICEF_2003.pdf [last accessed 20/08/09].

${ }^{73}$ Crouse, J. S. (2004) 'Two Gatherings: Which Agenda is Extreme?' Concerned Women for America, 27 April, 2004. See http://www.cwfa.org/articles/5726/BLI/dotcommentary/index.htm [last accessed 26/08/09].

${ }^{74}$ Ibid.
} 
Secularism plays a very important role in 'pro-family' discourse. Feminism is just one of many issues highlighted by 'pro-family' groups, in which its proponents trace the root cause of 'anti-family' outcomes back to the drift away from religion. In 'pro-family' texts, secularism, feminism and fertility decline all exist in a coconstitutive cycle. This is no accident: Carlson suggests in 1999 that advocates of what he calls the 'diminished child, post-family order' are well aware of the demographic trends that secularism encourages:

'They look for the levers that will engineer fertility decline and result in fewer children. They understand, all too well, that the values behind the second demographic transition face only one real opponent: vital religious faith. They know that if religion can be defeated, marginalized, or "converted" to their side, they will win. ${ }^{75}$

In this text, Carlson depicts religion and fertility locked in a fierce battle against secularism and contraception: fewer children signal the demise of religious faith, and vice versa. And it is not only religious faith, but uncompromising orthodoxies that are required to reverse the 'virulent secular individualism' Carlson sees threatening to 'complete its work' in the near future. ${ }^{76}$

C-Fam's Sylva bemoans what he calls 'the steady drumbeat to eliminate the influence of Christianity from international political affairs,' which he argues is continuing 'among radical pro-abortion non-governmental organizations. ${ }^{77}$ Here again, sexual and reproductive rights are seen more as symptoms of the effort to eject God from public and private life, rather than being the cause of this ejection. Seeing the presence of religion as the key to preserving morality in the international sphere, 'pro-family' groups see themselves as maintaining a space for religion in global affairs.

For CWA, a crucial test of the acceptability of feminist ideas is whether they are religious or not. As was touched on earlier in this chapter, more recent CWA texts

\footnotetext{
${ }^{75}$ Carlson, A. (1999) 'Depopulation and the New World Social Order,' Keynote Address to the Australian Regional Conference of the World Congress of Families II, Melbourne, Australia, August 7, 1999. Available at http://www.profam.org/docs/acc/thc_acc_depop.htm [last accessed 26/08/09]. ${ }^{76}$ Ibid.

${ }^{77}$ Sylva, D. A. (2004) 'CFFC Seeks to Eliminate Pope's Pro-Life "Armada" from Europe,' Friday Fax, vol. 7, no. 3, January 9, 2004. Catholic Family and Human Rights Institute, available at http://www.c-fam.org/publications/id.338/pub_detail.asp [last accessed 26/08/09].
} 
on this topic state that 'modern feminism has abandoned its religious founders. ${ }^{, 78}$ Secular progressives, in this view, have 'hijacked' feminism, and it is up to 'Conservative Christians, ${ }^{79}$ and 'Godly women' ${ }^{, 80}$ to return it to its religious roots.

Feminism is attributed to industrialisation in a 2002 speech by Carlson. In his view, development has caused feminism because the movement of work away from the home deprives women of their economic purpose. In an article entitled 'When Feminism Was a Mental Illness: Tales and Lessons from the 1950s,' Carlson offers a parallel between what he sees as feminist angst, and the suburban neuroses suffered by bored housewives. In his view, both of these result from the excesses of the industrial revolution, which continues to drive work out of the home and into factories. This reorganisation of production, says Carlson, renders work done at home less valuable, makes women bored, anxious and disturbed, and deprives them of the social support wives and mothers in more agrarian settings once enjoyed. He carries his analysis of feminist neuroses back to Mary Wollstonecraft, arguing that she was a 'masochist,' whose secret heart's desire was that her lover would marry her and that they would have a large family. Carlson concludes his article by offering the following advice to his 'pro-family' friends:

'...the next time you confront an angry feminist-be it in court, in Congress, or in public debate-you might remember Mary Wollstonecraft and perhaps see that you actually face another woman looking desperately for her true and real home. ${ }^{, 81}$

The solution to feminism, Carlson suggests, is to de-industrialise some parts of our lives, to allow mothers to fulfil meaningful economic and social functions from home. Carlson has chosen to pity feminists here, offering his readers an analysis which ranges from psychology to economics as a means of explaining why feminists are the way they are. In this reading, Carlson is either unwilling or unable

\footnotetext{
${ }^{78}$ Porowski, S. (2003) 'Hijacking a Noble Cause: How Modern Feminism has Abandoned its Founders,' Concerned Women for America, 26 September, 2003. Available at http://www.cwfa.org/images/content/early-v-mod-fem.pdf [last accessed 26/08/09]. ${ }^{79}$ Ibid.

${ }^{80}$ LaHaye, B. and J. S. Crouse (2002) 'The Strength of a Godly Woman,' Concerned Women for America, 2 February, 2002, available at http://www.cwfa.org/articledisplay.asp?id=3154\&department=BLI\&categoryid=misc [last accessed 26/08/09].

${ }^{81}$ Carlson, A. (2002) 'When Feminism Was a Mental Illness: Tales and Lessons from the 1950s,' the Family in America, vol. 16, no. 10, October, 2002. Available at http://www.profam.org/pub/fia/fia 1610.htm [last accessed 26/08/09].
} 
to see feminists as the drivers of social change, preferring to represent them as victims of an economic system that no longer values them. Like the most ardent of Marxists, Carlson sees the mode of production in society as being causally connected to the social relations of the people within it. Using this framework, we could say that Carlson perceives feminism as an instrument of false consciousness, superficially promoted as a means of increasing women's freedoms, but actually serving the interests of those who stand to benefit from the use of women's bodies, be they industry, individuals or officials.

Though perhaps not perfectly representative of the 'pro-family' position on feminism, Carlson's understanding of the psychology of feminists (as produced by the way the world has become) shows the degree to which he prefers to see feminism as a symptom, rather than a cause, of the outcomes to which he so strongly objects. This renders feminists less powerful in Carlson's view, leading him to seek a greater authority for his 'pro-family' forces to attack. Carlson has no qualms in pointing the finger at aspects of capitalism (particularly consumerism and excessive individualism) and secularism, as the primary contributors to the problems he sees in society today. From this perspective, feminists are to be pitied for their deranged views, which Carlson sees as being brought about by a social and economic system that forces women to conform to an unnatural state of existence.

Feminism is frequently associated with postmodernism in 'pro-family' discourse. Mainstream society is 'post-modern' according to most 'pro-family' observers, and this condition is a much bigger problem than feminism, because it trivialises religion and questions the very existence of God. By the term post-modern, 'profamily' organisations mean 'morally relativistic thinking' and the rejection of 'all notions of authority and overarching meta-narratives. ${ }^{82}$ This is contrasted with the

\footnotetext{
${ }^{82}$ See for example, Dobson, J. C. ((2002) 'Odd, Outrageous and Over the Top,' Focus on the Family, January 2002. Available at http://www2.focusonthefamily.com/docstudy/newsletters/A000000362.cfm [last accessed 26/08/09], and Köstenberger, A. (2006) Feminism, Family and the Bible: A Biblical Assessment of Feminism's Impact on American Families,' the Religion and Society Report, vol. 23, no. 1, January/February 2006. The Howard Center, available at http://www.profam.org/pub/rs/rs.2301.htm [last accessed 26/08/09].
} 
'time-honored, Judeo-Christian principles' ${ }^{83}$ espoused by 'pro-family' organisations.

In its promotion for the $2007 \mathrm{WCF}$, a C-Fam author writes that the Congress was originally founded in response to a militantly anti-family ethos prevalent in the "post-modern" West, and explains the conference's purpose as restoring the family as the 'seed-bed of a sane society. ${ }^{84}$ In its perceived attempts to sever society from the norms of the past, feminism is again linked to social chaos and insanity.

A number of Focus authors see feminist ideology as a product of post-modernism, with the individual left to work out how to best live his or her own life. ${ }^{85}$ Seductive in its appeal, the 'postmodern world' pulls individuals

'...into a vacuum of self-centeredness, whispering, "It's all about you." It's all about your own pleasure, peace, prosperity, and comfort. It's all about what you think. It's all about your own self-actualization, your individual pursuit. ${ }^{86}$

This pursuit for 'worldly success really is a big lie,' says the author. He attributes depression, drug use and other social ills to the self-serving worldview which he believes is brought about by post-modern thought. The FRC also sees postmodernism's 'guiding principles' as leading to a 'me' culture. These principles 'equality overseen by experts and a relentless consumerism' - are placed in opposition to belief in a Christian God. ${ }^{87}$ In this light, post-modernism and its associated ideas are a larger cause for concern to 'pro-family' groups than feminism alone.

\footnotetext{
${ }^{83}$ Dobson, J. C. ((2002) 'Odd, Outrageous and Over the Top,' Focus on the Family, January 2002. Available at http://www2.focusonthefamily.com/docstudy/newsletters/A000000362.cfm [last accessed 26/08/09].

${ }^{84}$ Singson, S. (2007) 'World Congress of Families Convenes in Poland,' Catholic Family and Human Rights Institute Friday Fax, vol. 10, no. 21, May 10, 2007. Available at http://www.cfam.org/publications/id.513/pub detail.asp [last accessed 26/08/09].

${ }^{85}$ See Dobson, J. C. (2004) 'Radical Feminism Shortchanges Boys: Dr Dobson Considers the feminist movement's affect [sic] on boys and shares an excerpt from Bringing up Boys,' November 2004, available at http://www2.focusonthefamily.com/docstudy/newsletters/A000000370.cfm [last accessed 01/06/09], for example.

${ }^{86}$ Tackett, D. (2006) 'Living in Reality' Focus on the Family, available at

http://www.focusonthefamily.com/faith/christian_worldview/why_is_a_christian_worldview_import ant/living_in_reality.aspx [last accessed 26/08/09].

${ }^{87}$ Family Research Council (2003) 'Historic Reality and Future Hope: Christopher Dawson's Vision of Christianity and Culture,' November 11, 2003, available at http://www.frc.org/get.cfm?i=WT03K01 [last accessed 26/08/09].
} 


\section{Part II: Tensions}

A number of issues arise in the 'pro-family' reading of feminism. Though feminism was frequently portrayed as an assault on society, increasingly 'pro-family' organisations are taking a more sophisticated view, seeing feminism as connected to (and a result of) other enemy ideologies. In this way, feminism has become both salvageable as a potential 'pro-family' political force, even though it may always be tainted by its association with 'anti-Christian' ideas. In this section, I consider some of the problems raised by 'pro-family' stances towards feminism.

\section{Cultural imperialism versus protecting women}

One major problem for 'pro-family' groups who take issue with feminists is that in arguing with feminists, the organisations often take an opposing stance that is itself a feminist one. In arguing that their ideas are better for women than the policies espoused by feminists in positions of power, 'pro-family' organisations end up using radical feminist arguments to best liberal ones, and vice versa. A focus on families, sexuality and reproduction seems destined to produce feminist arguments of some kind, even from the most ardent of 'anti-feminists.'

Many of the major successes 'pro-family' organisations have enjoyed have been in areas which divide Western feminists. One such example is sex-selective abortion. In the 'pro-family' view, abortion is a choice that should not exist, so sex-selective abortion appears as yet another morbid symptom of the widespread availability of the practice. Though they speak about the trend with sadness, however, 'pro-family' organisations struggle to restrain the victorious tone with which they discuss sexselective abortion. On a 'pro-life missionary trip' to India, for example, Euteneuer declares that he yearns to find a 'radical American feminist' to confront with the issue

'... and ask her if abortion is still a woman's sacrosanct right when it targets girl children in the womb. This is the radical feminist's Catch-22: to them abortion is a fundamental right necessary for women's self-realization, but it is more like selfdestruction when it is used to search out and destroy women before they are born. ${ }^{, 88}$

\footnotetext{
${ }^{88}$ Euteneuer, T. J. (2003) 'Pro-Life Missionary Trip: India,' Human Life International, 19 November, 2003. Accessed at http://www.hli.org/mission_india_2003.html [last accessed 17/11/06].
} 
In her discussion of the UN's dilemma over this issue, Crouse catches the UN in what she calls a position of 'cognitive dissonance,' in which the UN is forced to admit 'the humanity of unborn girls. ${ }^{89}$ She concludes her article with confidence that "in due time, the bitter fruit of "choice" will be recorded in the pages of history." 90 'The notion of sex-selection abortion challenges the liberal concept of abortion as an innate human right,' argues Ken Blackwell of the FRC. ${ }^{91}$ As can be seen here, for 'pro-family' organisations, pre-natal sex selection 'shows' anyone in doubt that abortion is wrong. The trend is portrayed as a serious chink in the armour of Western feminists, which can be prised open to show that the whole Western feminist project is in disarray. Yet 'pro-family' organisations do acknowledge that there is more to this issue than abortion alone. Most articles on sex-selective abortion also mention infanticide, and recognise that a major aspect of the problem is the status of women and girls in those countries in which the practice is a serious problem. Euteneuer, for example, emphasises the culpability of Indian culture in his appraisal of the problem, although he also blames Western 'hate-mongers' who 'constantly preach overpopulation' to a receptive Indian audience. ${ }^{92}$

Female genital mutilation is another issue in which 'pro-family' organisations, like many feminists, end up condemning cultural practices in favour of a set of higher universal values. Some experienced members of the 'pro-family' movement are aware of potential traps here, however. In a WCF speech on the activities of the 'anti-family faction' at the UN, veteran 'pro-family' activist Kathryn Balmforth warns that feminist treatment of this practice should be treated with caution. 'Feminists,' says Balmforth,

'...always insist on condemning "female genital mutilation and other harmful, traditional practices." This phrase has always seemed to me to be a potential source

\footnotetext{
${ }^{89}$ Crouse, J. S.(2007) 'the United Nations' Abortion Dilemma,' Concerned Women for America, 2 March, 2007. Accessed at http://www.cwfa.org/articles/12441/BLI/reports/index.htm [last accessed 27/08/09].

${ }^{90}$ Ibid.

${ }^{91}$ Blackwell, K. (2007) 'Protecting the Human Dignity of the Girl Child Worldwide,' Family Research Council. Available at http://www.frc.org/get.cfm?i=PV08L11 [last accessed 26/08/09].

${ }^{92}$ Euteneuer, T. J. (2003) 'Pro-Life Missionary Trip: India,' Human Life International, 19

November, 2003. Accessed at http://www.hli.org/mission_india_2003.html [last accessed 17/11/06].
} 
of mischief. Sure enough. I recently obtained a report of an NGO meeting held in Nigeria... which lists "virginity" among the "other harmful, traditional practices. ${ }^{, 93}$

However, if Balmforth senses the danger in condemning traditional practices because they are harmful, this warning has not been picked up by other 'pro-family' activists who see cultural relativism as a serious weakness of the political Left. Crouse quotes with approval one commentator's view of Western feminism 'as "soft" in its "romanticization of other cultures" and its relativism on critical issues. $^{94}$

The resolute stances of 'pro-family' organisations, in cases like those described above, make the movement appear strong and decisive compared to its feminist opponents. However, such clear resolutions favour universal approaches to morality rather than local traditions and religions: the same 'cookie-cutter' standard which 'pro-family' organisations have frequently opposed. In choosing between cultural variety and universal morality (which depends on the issue in question) 'pro-family' organisations struggle to decide whether women in the developing world should be treated as victims or as responsible rights-bearers. Deep at the heart of this conundrum is a basic indecision about freedom, especially women's freedom. Western feminists also struggle with this, and like Western feminists, 'pro-family' organisations must choose a course between mothering innocent women in the South or leaving morally culpable women to suffer their fate.

\section{Is feminism 'the problem' or not?}

Although they all state their opposition to 'radical' feminists, the 'pro-family' groups studied here struggle to say whether feminism is a powerful presence in world affairs or not. That some 'pro-family' organisations depict feminists in a 'new sex alliance,' a supposed global effort to overhaul family relations, is perhaps the clearest indicator of the 'pro-family' movement's acknowledgment of feminism as a serious power in world affairs. Carlson and his colleagues in 2003 stated that

\footnotetext{
${ }^{93}$ Balmforth, K. (1999) 'Hijacking Human Rights: Remarks to the WCF II,' November 17, 1999. World Congress of Families, available through the Howard Center at http://www.worldcongress.org/wcf2_spkrs/wcf2_balmforth.htm [last accessed 27/08/09].

${ }^{94}$ Crouse, J. S. (2005) 'Dowd Declares Feminism's Defeat: her bitterness is palpable.' Concerned Women for America, 21 November, 2005. Available at http://www.cwfa.org/articles/9503/BLI/commentary/index.htm [last accessed 27/08/09].
} 
'liberal or equity feminism' was perhaps the most successful ideology of the $20^{\text {th }}$ century. ${ }^{95}$ However, having both exaggerated and discredited feminist ideas, it is odd that the groups consider such a deranged ideology to be so appealing, and dangerous in its potential to change human relations all around the world.

The groups all have slightly different takes on why feminism is so dangerous. HLI sees the influence of feminists in terms of their ability to corrupt, whilst C-Fam prefers to stress the procedural deception of feminists at the UN as the reason for their political successes in the development arena. In this way, C-Fam sees feminists' strength in their tactical expertise rather than in the appeal of their ideas. While CWA comes close to accepting that the type of feminism they deride is in some way tempting to young women who want careers and independence, the organisation baulks at conferring feminism with any genuine legitimacy in the debate about what is best for women. Focus and FRC stress the difference between what they see as legitimate feminist gains and 'radical' feminist attacks on the family. The latter are appealing to women and men because they offer the selfish individual the opportunity to gratify their desires without guilt in a self-centred, morally relativistic society. Of all the groups discussed here, it is the Howard Center that comes closest to appreciating why women might embrace feminism, and seeing feminism as a powerful force for change. Yet this organisation, more than the others, consistently looks beyond feminism in an attempt to find a greater power that has brought about the 'anti-family chaos' it so desperately seeks to reverse.

This uncertainty about the influence of feminism makes it difficult for the groups to decide exactly how to deal with it. 'Pro-family' groups searching for a global nemesis seem to settle for feminism some of the time, but continue to search for a more powerful or more satisfying enemy. In this we can see recognition on the part of 'pro-family' groups that either feminists simply cannot be blamed for all the ills of the world, or that they do not want to grant feminists that degree of influence.

\footnotetext{
${ }^{95}$ Carlson, A. (2003) 'The Curious Case of Gender Equality,' the Ingersoll Prize Symposium, Belmont, North Carolina, 17-18 November, 2003. The Howard Center, available at http://www.profam.org/docs/acc/thc acc 031017.htm [last accessed 26/08/09].
} 
But to look beyond feminists as the enemy means finding a better culprit to blame for society's ills. This most often results in criticism of global capitalism, the UN system, or a general unease about individualism and liberalism. These are things the 'pro-family' movement struggles to condemn without raising a host of other issues. Criticism of global capitalism means an uncomfortable lean away from free trade, and the problem of what to advocate in its place. ${ }^{96}$ Condemning the UN means attacking the institution that serves as a platform through which they can forge new alliances and pursue their goals. Criticising individualism is perhaps the most potentially problematic, as 'pro-family' values still attach great importance to individual responsibility (and consequently, choice).

\section{Pro-woman opposition to feminism is feminism}

In the last decade and a half, 'pro-family' organisations have turned their customary opposition to feminism into a movement that can in fact be described as a version of feminism. In criticising feminist successes in improving women's access to health, 'pro-family' organisations actually employ feminist arguments, entering debates within feminism about what is best for women.

In the 'pro-family' view, women need to be valued in their capacity as wives and mothers because that is how women naturally find the most fulfilment. This view owes much to John Paul II's call for a 'new feminism,' which values the ways that women are 'functionally' different from men. 'Pro-family' organisations use arguments based on 'gender complementarity' to contest liberal feminist policies that they see as harmful to women. But in seeking to value women in all the ways that they are different to men, 'pro-family' groups advance a form of feminism that is not dissimilar to the 'radical' feminists they treat with such contempt. In opposing prostitution, for example, 'pro-family' organisations take a political stance with which many feminists agree. When 'pro-family' organisations claim that women's bodies are exploited through contraceptives and abortion, they are making the same arguments that radical feminists have made since the dissemination of these technologies in the 1960s and 1970s. On the other hand, in their opposition to quotas and legislative 'special treatment for women,' 'pro-family' groups take a

\footnotetext{
${ }^{96}$ For more on the tensions within the US political Right in this area, see Butler, op. cit., pp. 135143.
} 
libertarian feminist perspective. When they oppose Western feminism as maternalistic, they borrow from postcolonial feminism. That they cover a broad range of feminist arguments in their rebuttal of feminism shows that even a rhetorical 'pro-woman' standpoint makes conservatives speak like feminists to some degree.

This may be a reflection of the fact that international 'pro-family' organisations have entered these debates through the development arena: arguments about women's health may have to be made from a 'pro-woman' perspective to be heard in development circles. 'Pro-family' concern about fertility decline in developed countries, for example, is an acknowledgement that issues around sexuality and reproduction, once considered by some conservatives as a private matter, are now justifiably in the public domain (in many cases, thanks to religious conservatives).

\section{Are women victims?}

'Pro-family' organisations appear to be torn as to whether women - and especially developing country women - are able to exercise free will and personal responsibility or not. In some cases, Western feminists are accused of making victims out of the women they are purporting to help. Crouse paraphrases Betty Friedan to show her audience that women are victims, according to feminists. ${ }^{97}$ In others, women in developing countries are depicted as needing bold assistance to help them out of their conditions, rather than access to a set of choices that "profamily' organisations see as useless at best, and morally indefensible at worst. In other words, feminists make women victims in need of rescue, but in some cases, 'pro-family' organisations feel compelled to rescue these same women, and sometimes for similar reasons.

Most 'pro-family' discourse around the 'real needs' of women in developing countries, intentionally or otherwise, relies on the victim status of women to a large

\footnotetext{
${ }^{97}$ Crouse, J. S. (2003) 'Crouse delivers speech at Princeton: a conservative critique of feminism,' Concerned Women for America, 8 October 2003. Available at http://www.cwfa.org/articles/4693/BLI/media/index.htm [last accessed 24/08/09]. See also CWA (1999) 'UNFPA and PPFA advance the victimization of women in Kosovo,' Concerned Women for America, 16 April, 1999. Available at http://www.cwfa.org/articledisplay.asp?id=1374\&department=CWA\&categoryid=life [last accessed 19/08/09].
} 
degree. Arguing that sexual and reproductive health services are offered where food, sanitation, medicine and shelter are called for, 'pro-family' organisations claim that proponents of sexual and reproductive rights are out of touch with the 'real' needs of women. Seeing a dichotomy between women's rights (as they are understood by progressives) and women's needs, 'pro-family' organisations attack rights based approaches to development as coming at the cost of meeting real needs.

In this way, 'pro-family' organisations do indeed see developing country women as victims of their situations. Western feminists cannot be lumped with all the blame for the problems faced by women in poor countries. Corrupt governments in developing countries are to blame for the poverty of its citizens according to a number of 'pro-family texts. ${ }^{98}$ HLI's Euteneuer blames 'Indian culture' for the 'second class status' of women in that country. ${ }^{99}$ Some texts see 'Islamic regimes' as a major cause of women's oppression. Many 'pro-family' texts acknowledge that poor development outcomes are caused by a combination of factors; in this sense, feminists have simply added fuel to the fire.

Women are often framed as lacking the ability to make the right choices in "profamily' discourse. In some cases, 'pro-family' organisations are able to portray their role as providing the choices that developing country women want to have, for example, through fighting against coercion and violence in the name of population control. This can also be seen in the efforts of 'pro-family' organisations to offer women what they 'really need.' Yet the ability to choose is in itself a problem in 'pro-family' discourse. This is not just because certain choices are seen as immoral, such as abortion and homosexuality, but also because the very availability of choices results in the satisfaction of individual preferences rather than the pursuit of moral goods. For example, for 'pro-family' organisations, choice devalues motherhood because it renders motherhood a decision rather than a selfless

\footnotetext{
${ }^{98}$ See, for example, Kiser, K. (2004) 'The United Nations: An Untold Story,' Concerned Women for America, 1 November, 2004. See http://www.cwfa.org/articledisplay.asp?id=6623\&department=BLI\&categoryid=reports [last accessed 26/08/09]. See also, Euteneuer, T. J. (2003 'Pro-Life Missionary Trip: El Salvador,' Human Life International, 30 June 2003. Accessed at http://www.hli.org/mission_el_salvador_2003.html [last accessed 21/12/06].

${ }^{99}$ Euteneuer, T. J. (2003) 'Pro-Life Missionary Trip: India,' Human Life International, 19 November 2003.Accessed at http://www.hli.org/mission_india_2003.html [last accessed 17/11/06].
} 
sacrifice. Where there is no choice, women may be victims, but they retain the potential for self-sacrifice, a virtue deeply valued in 'pro-family' discourse.

At the heart of this issue is uncertainty about women in the developing world. Application of core 'pro-family' tenets like virginity before marriage assumes a degree of autonomy that women in poor countries do not universally enjoy. If women are victims of cultural oppression, economic underdevelopment, or brutal regimes, their ability to choose the 'pro-family' blueprint for development is severely compromised. That 'pro-family' groups do not see 'women's empowerment' as the answer to this issue is clear. But what is the alternative for these self-proclaimed 'pro-woman' organisations?

\section{Conclusion}

Though it remains a key aspect of their global agenda, the research in this chapter shows that 'pro-family' characterisations of feminism are becoming more diverse. Despite the enormity of its twentieth century successes, feminism is still often seen as a symptom rather than a cause of social change in 'pro-family' texts. Feminists are sometimes the dupes of corporate capitalism and at other times mentally ill in the 'pro-family' worldview, but they are increasingly pushed aside as 'pro-family' organisations struggle to identify the real influence behind the 'anti-family' changes of the last few decades.

More recent depictions of feminism see it as deriving from (or connected to) other ideological enemies of conservative Christianity: socialism, Marxism, liberalism, and postmodernism. Yet it should be noted that this expansion of enemies is still articulated in terms of women's rights and roles. Marxism is a problem because of the role it plays in 'pitting women against men,' socialism is likewise derided because it 'attacks' the father-led family, and so on. In their development activism, 'pro-family' groups reject feminism on behalf of poor women in the South, thereby saving them from materialism, consumerism, childlessness and other evils associated with this cluster of bad ideas.

Like many feminists who have had second thoughts about the sexual revolution, 'pro-family' organisations do pinpoint real issues faced by women as a result of the 
liberalisation of sexuality and reproduction. In many ways, feminism has been at least partly responsible for increasing the pressures and multiplying the expectations placed upon women. Yet this is not the negative aspect of feminism that 'pro-family' groups use in their arguments. 'Pro-family' groups choose instead to talk in terms of the 'corrupting' effects of feminism. And feminism, 'correctly' applied, need not be corrupting at all, say the organisations. In the separation of a virtuous 'pro-family' feminism from a corrupting 'radical' feminism, 'pro-family' organisations highlight the influences of old foes (communism and secularism, for example) in the makeup of the feminism they do not like. In this way, feminism is diminishing as a 'pro-family' enemy, and being replaced with its alleged ideological support systems: individualism, secularism and materialism.

These belief systems could be understood in terms of 'unseen enemies,' as Herman puts it, or even a tendency towards conspiracy, which looks beyond an evident global enemy to find something darker and more powerful. However, I suggest that the new enemies of the 'pro-family' movement may be unseen, but they are specified. Secularism, individualism and materialism have emerged as the global 'anti-family' forces of the twenty-first century and feminists are again relegated to puppet status, but this time under the control of bad ideas rather than bad people.

Nowhere is this clearer than in 'pro-family' discourse around 'demographic winter,' in which 'pro-family' organisations embark on an effort to save humanity from these forces. Fighting the feminist threat may be on the backburner, but the "profamily' movement must be ever vigilant against the ideas that spawned feminism: the fertility and future of the 'human family' may depend upon it. 
Chapter Six: From 'population controllers' to 'demographic winter': the changing threat to fertility in 'pro-family' discourse

'Our foes are dying, of their own choice. We have a world to gain. Natural families of all races, nations and creeds, let us unite.'

The Howard Center, $2005^{1}$

Fertility decline has nearly always been considered in negative terms in "profamily' discourse. Since the time they became interested in the world outside the US, 'pro-family' organisations have tended to depict fertility decline the work of powerful global elites and nefarious (and often Marxist) forces under the rubric of population control. Various entities have been held responsible for population control in 'pro-family' discourse. Some 'pro-family' leaders have depicted environmentalists and academics as broadcasting a 'population bomb' message that has been picked up by elites and broadcasted throughout the world. Others emphasise population control as a joint conspiracy between NGOs, Western governments and the UN. Occasionally, the governments of developing countries have been blamed for their efforts to limit their population growth.

Articulating population and development issues within a human rights framework (as epitomised in the Cairo conference) was the catalyst for the emergence of "profamily' organisations into development politics. As already noted in chapter one, it was not population control per se that brought the 'pro-family' movement into the international arena, it was when reproductive rights became the framework through which population policy was discussed that 'pro-family' organisations entered the debate.

Buss and Herman devote a chapter of Globalizing Family Values to Christian Right politics around population and development. They suggest that for 'pro-family' groups, population policy embodies the threats to 'family, nation and church' more than any other issue, because it brings together 'abortion, contraception, women's

\footnotetext{
${ }^{1}$ The Howard Center (2005) 'The Natural Family: a Manifesto,' WCF Update, Online! vol. 6, no. 12, 22 March, 2005, available at http://www.worldcongress.org/WCFUpdate/Archive06/wcf_update_612a.htm [last accessed 27/08/09].
} 
rights, the "internationalization" of social relations and the global centralization of power. ${ }^{2}$ Opposition to abortion is the core of the issue for 'pro-family' groups, as a number of observers have discerned. ${ }^{3}$ On top of this, Buss and Herman suggest that population policy is understood as part of a global 'culture of death,' and the source of other assaults on the "natural family.'4

'Pro-family' organisations have depicted a variety of international entities feminist NGOs, governments, and international development organisations - as working together to spread 'the population control agenda.' Environmentalism is also tainted by its connection with population control in 'pro-family' texts. Sometimes considered by 'pro-family' organisations as ideologically interchangeable with population control, environmentalists are accused of trying to protect the environment at the cost of human life. Though some feminists have sought to clarify their position vis-à-vis the environment - that women's health rights ought to be enjoyed regardless of their effect on the environment - the promotion of sexual and reproductive rights has enjoyed the support of environmentalists because they allegedly relieve the environment of the burden of increasing numbers of humans. ${ }^{5}$ Environmentalism, in early 'pro-family' discourse, was seen as a device used by globalists to augment their power and bring about a 'new world order.' Environmentalism has thus existed both as an enemy ideology in its own right, as well as a misused science implicated in what 'pro-family' organisations have viewed as the immoral and brutal practice of population control. Though 'pro-family' groups remain suspicious of environmentalism, over time they are changing the way they think about environmental issues, increasingly incorporating them into an agenda in support of the 'natural family.'

\footnotetext{
${ }^{2}$ Buss, D. and D. Herman (2003) Globalizing Family Values: the Christian Right in International Politics, (Minneapolis: University of Minnesota Press), p. 57.

${ }^{3}$ See chapter one of this thesis for more on this.

${ }^{4}$ Buss and Herman, op. cit., p. 62.

${ }^{5}$ Though as Rosalind Petchesky notes, the link between environmental degradation and population growth has always been a spurious one. She writes that 'the dominant path to modernity has meant more and more things in place of children; plenitude, not people, is the worst polluter.' See Petchesky, R. P. (2000) 'Reproductive and Sexual Rights: charting the course of transnational women's NGOs,' Geneva 2000 Occasional Paper No. 8, United Nations Research Institute for Social Development, p. 24.
} 
As the 'pro-family' discourse around 'globalists' has changed, so too has the way that 'pro-family' groups oppose international development initiatives seeking to widen access to effective contraception and safe abortion. In their 2003 work, Buss and Herman trace a change in 'pro-family' rhetoric, from opposing population control and abortion as the 'tool of an emerging Marxist world government to a "softer" focus on poverty, third world development, and 'the rights of poor women. ${ }^{6}$ Although this characterisation is correct, I suggest that there has been another significant shift in the way that 'pro-family' groups discuss population policy. In this chapter, I show the way that 'pro-family' population discourse is moving away from advocacy on behalf of women in developing countries, towards emphasis upon the demographic problems of the Western world. 'Pro-family' groups, I suggest, now see fertility decline as a cultural issue. ${ }^{7}$

This is exemplified in a 2008 film produced by 'pro-family' activist Don Feder, entitled Demographic Winter: the decline of the human family. The makers of this 'pro-family' documentary intend to show how 'social science and economics come together to declare a looming demographic winter which threatens to have social and economic consequences. ${ }^{8}$ Set to an unsettling score, Demographic Winter provides testimony from a range of social science 'experts' who warn their audience of what they can expect from the social and economic fallout which they argue will accompany depopulation.

In this chapter, I illustrate the different ways in which 'pro-family' discourse portrays declining fertility - or as it is increasingly called, 'demographic winter' and its relationship to the 'natural family.' The first part of this chapter considers 'pro-family' characterisations of population control, and the way discourse on fertility decline is shifting to incorporate new issues about modern society that 'profamily' groups highlight as a problem. This part shows the way that 'pro-family' discourse on fertility has shifted towards discussion of 'demographic winter,' in

\footnotetext{
${ }^{6}$ Buss and Herman, op. cit, p. 58.

${ }^{7}$ Fertility decline is broadly understood as population birth-rates below 2.1 births per woman (this does not necessarily correspond to an absolute decline in population numbers). Buss and Herman do briefly acknowledge depopulation as an aspect of a new Christian Right 'science,' but it is not a theme that they pursue in detail. Ibid, pp. 68-9.

${ }^{8}$ See 'Demographic Winter: the decline of the human family,' SRB Documentary, LLC. Available at http://www.demographicwinter.com/index.html [last accessed 30/08/09].
} 
terms of its purported effects and what is causing it. The second part of this chapter considers the tensions and complications in this relatively new 'pro-family' way of talking about fertility.

\section{$\underline{\text { Part I: Fertility in 'pro-family' discourse }}$}

\section{Population Control}

With the Vatican, 'pro-family' organisations have rallied against population control and many still articulate their international policies in terms of opposing the practice. As other observers have noted, since their emergence on the international scene, 'pro-family' organisations have justified their international activity as protecting women, and particularly women in developing countries, from human rights abuses carried out in the name of 'population control.' Leaders in the 'profamily' movement often point to a time of population alarm - spanning the 1960s, 1970s and early 1980s - in which women's reproductive capacity was targeted as a problem. This time, writes Allan Carlson, was 'a time of open war on human nature, and on human fertility, one directed in particular against women.' According to Carlson, population control 'ruthlessly condemned the gift granted to women of bearing new life.' 9

In 'pro-family' discourse, population control has been seen as a conspiracy between a set of global elites: feminist NGOs, Western governments, and international organisations, especially the World Bank and the UN. These 'population controllers,' 'pro-family' groups maintain, have used arguments about the carrying capacity of the Earth to increase the uptake of their message. Rather than bettering the lives of people in developing countries, say 'pro-family' leaders, the efforts of these elites have actually hindered development, because countries must now prepare for rapid depopulation. I discuss each of these 'pro-family' perspectives in detail in the following section.

Population control is seen as a conspiracy between feminist NGOs, Western governments and international organisations in a number of 'pro-family' texts. As

\footnotetext{
${ }^{9}$ Carlson, A. (1998) 'Twenty-Five Years into the Culture of Death,' Talk for the Rockford Pro-life Breakfast for Clergy and Lay Leaders, 9 January 1998. The Howard Center, available at http://www.profam.org/docs/acc/thc.acc.980109.RvW25th.htm? [last accessed 28/08/09].
} 
was discussed earlier, 'radical feminists' and 'population controllers' are seen as staunch allies in many 'pro-family' texts. Where they have not been assumed to be the same people, feminists have been accused of working alongside 'population controllers' and international agencies to bring about stark reductions in fertility in the developing world, against the will of women and their families. In a flyer promoting the $2004 \mathrm{WCF}$, for example, 'militant feminists' were listed alongside 'population controllers' and the 'socialist Left' as the foes of the 'natural family., 10

Connecting people from different ideological standpoints joining for the purpose of promoting the 'anti-family,' 'anti-child' agenda is common in older 'pro-family' texts. In a 1997 article, Focus condemned a number of Republicans for joining their Democrat opponents in giving over $\$ 400$ million to the International Planned Parenthood Federation and similar groups for overseas population control, including abortion. ${ }^{11}$

Similarly, in a 2006 text, HLI still sees a combination of different forces at work driving the population control agenda, in what it refers to as an 'aggressive international culture of death. ${ }^{12}$ In HLI's view, 'population controllers' are a force external to national governments, who 'move into' countries. ${ }^{13}$ In a trip to Nigeria, HLI's Brian Clowes reports that

'Regarding foreign aid, it is the usual story in Nigeria. Millions go without clean drinking water, electricity, basic health care, safe transportation, safe food, or any of the many other necessities of life that you and I take for granted. Yet the US Agency for International Development (USAID), the United Nations Population Fund (UNFPA), the International Planned Parenthood Federation (IPPF) and all of the

\footnotetext{
${ }^{10}$ By the time of the $2007 \mathrm{WCF}$, however, Carlson and his organisation declare their intention to shift the "terms of certain key public debates... From "overpopulation" to "underpopulation" as the demographic problem facing the $21^{\text {st }}$ century.' See both the Howard Center's Family Update Online! vol. 5, iss. 51, http://www.worldcongress.org/WCFUpdate/Archive05/wcf update 551.htm? and Carlson, A. (2005) 'The Values Vote Goes Global: On the World Congress of Families, http://www.profam.org/docs/acc/thc.acc.050224.frc.wcf.htm? [both accessed 28/08/09].

${ }^{11}$ Dobson, J. (1997) 'Dr Dobson Discusses Families Under Fire,' Focus on the Family, July 1997. Available at http://www2.focusonthefamily.com/docstudy/newsletters/A000000280.cfm [last accessed 28/08/09].

${ }^{12}$ Human Life International (2006) Special Report, no. 264, December 2006, p. 5. Accessed at http://www.hli.org/sr_dec_06.pdf [last accessed 30/01/07].

${ }^{13}$ See Mosher, S. W. (2004) 'Unto the least of these my brethren: US population control policy.' Speech given at the World Congress of Families III, Mexico City, 29 - 31 March 2004. Available at http://www.worldcongress.org/wcf3 spkrs/wcf3 mosher.htm? and repeated in the Family in America, vol. 18, no. 9. http://www.profam.org/pub/fia/fia 1809.htm [both accessed 28/08/09].
} 
other anti-life groups insist on stocking village dispensaries with thousands of condoms, Norplant kits, and cycles of birth control pills. Their only concern seems to be turning large poor families into small poor families. ${ }^{, 14}$

Portraying their opponents as an international collection of different entities, each promoting their own agenda as well as the overall goal of fertility reduction, HLI sees enemies everywhere. 'Population controllers,' states Euteneuer in Kenya, 'are killing our world,' with support from 'huge governmental and private interests promoting these nefarious agendas. ${ }^{15}$

Reflecting on population control in 2008, Carlson argues that the movement has been a 'successful conspiracy.' ${ }^{16}$ In a panel discussion with other 'pro-family' intellectuals, he suggests that a small 'wealthy cabal' of Americans were behind the population control movement, and essentially 'turned US foreign aid into a global birth control programme. ${ }^{17}$ The actions of these elites, he reveals, have had an enormous impact on fertility rates all around the world.

This 'cabal' has been assisted by international organisations in their efforts to broadcast the contraceptive message, say 'pro-family' leaders. 'Pro-family' groups are well aware that without international organisations, particularly the UN and the World Bank, fertility reduction programmes would have enjoyed less legitimacy in the developing world. C-Fam has been especially active in accusing international organisations of unauthorised meddling in the affairs of sovereign countries. The World Bank, UNICEF and UNFPA have been targeted in three separate C-Fam 'White Papers' which accuse the organisations of going beyond their mandate in their promotion of population control. ${ }^{18}$

\footnotetext{
${ }^{14}$ Clowes, B. (2004) 'Pro-Life Missionary Trip: Nigeria,' Human Life International, May 25th 2004, accessed at http://www.hli.org/mission_nigeria_2004.html [last accessed 16/11/06].

${ }^{15}$ Euteneuer, T. J. (2002) ‘Pro-Life Missionary Trip: Kenya,' Human Life International, 1-8 September 2002. Accessed at http://www.hli.org/mission_kenya_2002.html [last accessed 17/11/06]. ${ }^{16}$ Carlson, Fagan and John Mueller participated in a panel discussion for the Family Research Council in 2008, which discussed the implications of Don Feder's 2008 documentary Demographic Winter. See 'Family Research Center's Family Policy Lecture: Demographic Winter Policy Discussion,' available at http://www.frc.org/get.cfm?i=PL08E02 [last accessed 28/08/09] (Carlson's reference to this 'successful conspiracy' occurs between 6:50 - 8:40).

${ }^{17}$ Ibid.

${ }^{18}$ For C-Fam's accusation of UNICEF promotion of population control, see https://www.cfam.org/docLib/20080424_Number_3_UNICEF_2003.pdf pp. 32 and 37. For the World Bank's alleged promotion of population control see http://www.c-
} 
Environmentalism and population control are seen as 'anti-people' in 'pro-family' discourse. In many texts, population control is caricatured as an ideology that prioritises animals and plants over human lives. One CWA article from 2006 explains that population control is 'an ideology that considers human beings a blight on the Earth, rather than creative and resourceful individuals with unique worth. ${ }^{19}$ As examples of population control, the author offers 'forced abortions and sterilisations and infanticide,' and goes on to paraphrase a widely misconstrued speech by Texan scientist Eric Pianka, who the author claims has advocated 'releasing the Ebola virus to wipe out 90 percent of the population.' 20

In a later article from 2006, a CWA author contrasts what he sees as the anti-human philosophical standpoint of religious environmentalists against the growing membership of conservative churches in the US. The author suggests that under the current leadership of an environmentalist, US Episcopalians will 'hold fast to their noble environmental stewardship and maintain a steady, and eco-friendly downward membership spiral. ${ }^{21}$ According to the author, the 'growing Anglican communion,' by contrast, 'view[s] people as gifts from God, not as parasites on an exploited planet earth. ${ }^{22}$

This depiction of environmentalism as anti-human is still widely shared in the "profamily' movement. HLI's 2008 Special Report offers its subscribers an audio discussion that claims to offer scientific evidence rebutting the contention that an environmental crisis is looming. The advertised audio CD offers HLI supporters the opportunity to

\footnotetext{
fam.org/publications/id.332/pub detail.asp in general. For UNFPA, see http://www.cfam.org/docLib/20080624_UNPF.pdf. [All accessed 20/08/09].

${ }^{19}$ Randall, L. (2006) 'Global Warming Fanatics Warming Up to Evangelicals: What's the real tactic?' Concerned Women for America, 19 December, 2006. Available at http://www.cwfa.org/articledisplay.asp?id=12033\&department=CWA\&categoryid=misc [last accessed 28/08/09].

${ }^{20}$ For more on this controversy, see 'Professor Criticised over Comments about Impending Pandemic,' ABC News, Texas, Tuesday April 4, 2006, available at http://abclocal.go.com/ktrk/story?section=news/ state\& id=4051760 [last accessed 27/5/09].

${ }^{21}$ Tooley, M. (2006) 'Not Much Thanksgiving for Episcopalians,' Concerned Women for America, 23 November, 2006. See http://www.cwfa.org/articledisplay.asp?id=11888\&department=CWA\&catego ryid=misc [last accessed 30/08/09].

${ }^{22}$ Ibid.
} 
'know the truth and reveal it to others before the extreme population control and environmental movements advance further in their quest to degrade the value of the human person. ${ }^{23}$

The advertisement concludes by declaring that "people are not pollution. ${ }^{24}$ 'Profamily' activists suggest that contrary to popular belief, the relationship between the number of people on Earth and the state of the environment is not inversely related. As such, they condemn efforts to spread contraceptives as a means of protecting the environment. In this way, environmentalism is portrayed in 'pro-family' texts as a false belief that puts people at the service of nature.

Population control and environmentalism are so frequently conflated that CWA refers to 'population-control environmentalists' in a 2006 article. ${ }^{25} \mathrm{CWA}$ quotes a likeminded institute as it explains how the ideology of environmentalists works:

'...since people use up natural resources, release $\mathrm{CO} 2$ into the atmosphere and otherwise pollute the environment, the fewer people, the less global warming and less harm to the environment. ${ }^{, 26}$

Wendy Wright, CWA's president, answers this attitude as follows:

'While it is absolutely necessary that Christians be good stewards of the Earth, there is no Biblical basis for elevating the Earth above human beings in priority. We care for Nature so it can sustain God's crowning creation - the only thing made in His image - mankind. When the mission comes in conflict with the Biblical, pro-life stance that evangelicals live by, it negates itself. ${ }^{27}$

This 'pro-family' stance on environmentalism is broadly shared by 'pro-family' organisations: the environment is precious only because people live in it. Countries should embrace environmental initiatives to support a growing global population, rather than try to stem the growth of humanity, say 'pro-family' activists. ${ }^{28}$

\footnotetext{
${ }^{23}$ Advertisement in HLI's Special Report, no. 279, March 2008, p. 8. Available through www.hli.org [last accessed [20/08/08].

${ }^{24}$ Ibid.

${ }^{25}$ Randall, L. (2006) 'ECI: Evangelical Christians Impolitic? The Hewlett Foundation's answer to global warming? Abort babies.' Concerned Women for America, 27 November, 2006. Available at http://www.cwfa.org/articles/11711/CWA/life/index.htm [last accessed 28/08/09].

${ }^{26}$ Ibid.

${ }^{27}$ Ibid.

${ }^{28}$ Finger, op. cit.
} 
By 2003, however, some 'pro-family' leaders began to acknowledge the potential for environmentalist principles to be used to support 'pro-family' arguments. Carlson suggests that the cultural aspects associated with fertility decline may actually be harmful to the environment. He quotes from an article in the journal Nature, which reports that even with declining fertility in the US and Italy (and in the case of the latter, a reduction in the absolute population) the actual number of households in both countries is increasing. ${ }^{29}$ This contributes to greater environmental decay, says Carlson. He concludes:

'Counter-intuitively, it turns out that the retreat from marriage and fertility decline are actually the cause of urban sprawl and environmental decay. Why? Larger families-on a per capita basis--use less land, fuel, building materials, and supplies than do singles and childless couples. Large family households, in a sense, are both more efficient and more environment friendly. But there are precious few of these today. ${ }^{30}$

This theme is explored in some detail in the documentary Demographic Winter. Jianguo Liu of Michigan State University calculates that divorce and the rise of individual households are causing a significant increase in the total demand for water and electricity in the US, even though overall population levels are stable. ${ }^{31}$ Liu and others make the case that population reduction policies are based on false premises about the relationship between people and the environment. This new approach puts environmentalism on the side of 'pro-family' politics. Just as they have done in other areas (feminism, for example), 'pro-family' organisations are increasingly finding ways to turn their opponents' ideologies against them.

Another example of this is the way that 'pro-family' organisations have attempted to turn an outcome desired by their adversaries - a global reduction in population growth - into a nightmare scenario that calls for the immediate establishment of 'pro-family' political 'solutions.' Some commentators are quite candid about this. CWA, for example, sees changing fertility levels as a boon for the 'pro-family'

\footnotetext{
${ }^{29}$ Carlson, A. (2003) 'World Population Trends and the Retreat from Marriage,' Speech to the Illinois Association of Scholars at Loyola University, Chicago, Illinois. The Howard Center, 5 April, 2003. Available at http://www.profam.org/docs/acc/thc_acc_loyola030405.htm [last accessed 30/08/09].

${ }^{30}$ Ibid.

${ }^{31}$ Liu calculates that in the US in 2005, 'people used an extra 600 billion gallons of water and 73 billion kilowatts of electricity.' See the 'environmental waste from divorce,' Demographic Winter: the Decline of the Human Family (2008) SRB Documentary, LLC, Acuity Productions [DVD] $(36: 50-37: 45)$.
} 
movement. In her analysis of a 2002 UN report that the world's total fertility rate has declined to its lowest ever rate, Crouse is satisfied to read that 'the focus has shifted to discussion about the end of population growth' in international development politics. In her article, she quotes a 'pro-family' interviewee, who remarks that

'God has given us a new weapon in our pro-life efforts; these new population projections have changed the minds of a lot of countries already. It has the potential to revolutionize the abortion issue because nations can now see that the pro-abortion stance will destroy their nation. ${ }^{32}$

This link between abortion, nationhood and fertility decline is an important one in 'pro-family' texts, because it brings together three issues which lie at the heart of discussions of both 'population control' and 'demographic winter.' This is not only because in 'pro-family' thought, nationhood is threatened both by abortion (in a spiritual sense) and reductions in fertility (in the sense of continued ancestral nationhood). It is also intimately connected to the contention that the recognition of sexual and reproductive rights owe their existence, at least in part, to the context of a global 'population bomb' mentality.

C-Fam took an early interest in depopulation. 'That the world is overpopulated has been a staple of education and media speculation for more than forty years,' reads one Friday Fax from 1999. ${ }^{33}$ Concerned with 'below replacement fertility, ${ }^{34}$ the author, Austin Ruse, warns that 'the ramifications of this project are only now being considered. ${ }^{35}$ The introduction to C-Fam's critique of the World Bank states that contrary to promoting fertility decline, 'the World Bank should begin studying how to increase fertility rates. ${ }^{36}$ The organisation opposes the link between fertility

\footnotetext{
${ }^{32}$ Crouse, J. S. (2002) 'The United Nations' Ubiquitous and Destructive "Footprints",' Concerned Women for America, 1 January 2002. Available at http://www.cwfa.org/articles/1953/CWA/nation/index.htm [last accessed 28/08/09].

${ }^{33}$ Ruse, A. (1999) 'Mainstream Media Increasingly Covers Emerging Depopulation Scare,' Friday Fax, vol. 2, no. 41, August 20, Catholic Family and Human Rights Institute. Available at http://www.c-fam.org/publications/id.104/pub_detail.asp [last accessed 28/08/09].

${ }^{34}$ Replacement fertility is a population-wide average estimated at 2.1 live births per woman, considered to be the number required to maintain a stable population over time.

${ }^{35}$ Ibid.

${ }^{36}$ Essig, A. M. (2007) 'The World Bank: How it compromises economic development by promoting a population control agenda,' International Organizations Research Group White Paper, Catholic Family and Human Rights Institute. Available at http://www.cfam.org/docLib/20080425_Number_7_World_Bank_2007.pdf $[$ last accessed 20/08/09], p. 2.
} 
decline and economic development that has been assumed in development circles, suggesting that 'high fertility' has historically been mistakenly viewed as a problem that needs correcting. ${ }^{37}$

Focus on the Family makes a similar point. In its discussion of 'the real problem' with the Earth's population, a Focus author writes that 'for the last several decades, the threat of overpopulation has dominated the discourse on global demographics. ${ }^{38}$ Although he acknowledges 'an upper limit' to the sustainability of the human population, the author goes on to say that ageing and low birth rates are the impending crisis, rather than overpopulation. ${ }^{39}$

HLI has also seized on the concept of falling fertility to support its opposition to birth control and abortion. In 2008, HLI still sees 'international death peddlars' at large in the world, ${ }^{40}$ but is also coming around to the idea that there is an indigenous (or domestic) demand for contraceptives that is driving fertility decline. Thus instead of only speaking out against 'population controllers,' HLI is beginning to follow its 'pro-family' allies and appeal to nationalism and ethnic identity in its activism. On a trip to India, one HLI spokesperson warns that 'India's total fertility rate has dropped to a dangerously low 2.7,' and in Goa the rate is $1.7 .^{41}$ The author goes on to say that 'I warned the people during my talks that if they continue having no children, there will come a time when there will be more foreigners than Goans. ${ }^{42}$ Although HLI does not (yet) use the term 'demographic winter,' this emphasis on out-breeding immigrants shows, at least to some degree, that HLI is moving beyond the older 'population controllers' framework to defend its policies. That HLI (which tends to lag the other organisations in adjusting its 'pro-family' discourse) is moving in this direction, suggests that amongst 'pro-family' groups, talk of population control may soon be confined to discussions about the past.

\footnotetext{
${ }^{37}$ Ibid, pp. 23 and 31.

${ }^{38}$ Finger, R. (2005) 'The Earth's Population: What is the Real Problem?' Focus on the Family Issue Analysis. Available at http://www.citizenlink.org/FOSI/worldview/A000001564.cfm [last accessed 30/08/09].

${ }^{39}$ Ibid.

${ }^{40}$ Human Life International's Special Report, no. 283, July 2008. Available at http://www.hli.org/sr_july_08.pdf [last accessed 29/05/09], p. 5.

${ }^{41}$ Ibid, p. 4.

${ }^{42}$ Ibid, p. 6 (emphasis in original).
} 


\section{Demographic Winter}

Though opposition to population control was a central platform for the activism of 'pro-family' organisations in the 1990s, discussions around fertility decline have changed significantly between 1997 and 2008. Leaders in the movement increasingly refer to depopulation as 'demographic winter' and have shifted much of their focus to the industrialised world, especially Europe. 'Demographic winter' is also referred to as the 'birth dearth,' a condition in which governments struggle with ageing populations and declining economies. In 'pro-family' discourse, 'demographic winter' is caused by factors internal to the process of industrialisation and modernisation. These factors are discussed at great length by 'pro-family' intellectuals. The reasons offered for declining fertility in developed countries are multi-faceted: a general movement away from religion; welfare, 'anti-family' taxation and state education; tolerance of homosexuality, abortion, and contraceptives; and materialism and selfishness as cultural norms. I consider each of these areas in turn, before discussing complications with this relatively new aspect of 'pro-family' discourse.

One of the first documented appearances of the term 'demographic winter' was at the second World Congress of Families in Geneva in 1999. ${ }^{43}$ The speaker, Senator Franscisco Tatad of the Philippines, warned his fellow 'pro-family' allies that

'In the West, a severe demographic winter has turned once vigorous societies into a murderous desert from which all celebration of conjugal love and human life has been banished forever. But unlike any other winter, it threatens to be permanent; there is no prospect of spring. One child will have to be shared by four lucky

\footnotetext{
${ }^{43}$ 'Demographic winter' stands in contrast to an economic development model that has been used by proponents of investment in sexual and reproductive health called the 'demographic window.' Both are efforts to use a demographic framework based on fertility to support a particular political view, but they work in opposite directions. The Demographic Window theory posits that the introduction and use of modern contraceptives increases the proportion of the working age population relative to their dependents (children and the elderly). Smaller families can save and invest more, and their societies as a whole can save and invest more in health, education and economic infrastructure. If the increased savings and investments are translated into increased productivity, suggest this theory's proponents, the achievements can be significant and ongoing. See, for example, Singh et al. (2003) 'Adding it up: the Benefits of Investing in Sexual and Reproductive Health Care,' UNFPA and the Alan Guttmacher Institute, http://www.unfpa.org/upload/lib_pub_file/240 filename addingitup .pdf [last accessed 13/06/09].
} 
grandparents; by contrast, a third world grandparent will have a riot of great grandchildren around him or her. ${ }^{, 44}$

Use of the term 'demographic winter' remained relatively infrequent until around 2003, when the term appeared to quickly gain currency in 'pro-family' discourse. Europe has been singled out by most commentators as being in an advanced state of 'demographic winter,' with Carlson suggesting the continent is in 'demographic freefall. ${ }^{45}$ Tatad, for his part, predicted in 1999 that 'Asians and Africans who manage to learn the language well will become tomorrow's Europeans. ${ }^{46}$ As such, Europe is frequently used as a warning for the rest of the world in 'pro-family' discourse, especially as a lesson of what happens when societies abandon Christianity.

'Demographic winter' is in some respects an echo of the eugenics movement from the late nineteenth and early twentieth century in the US. ${ }^{47}$ Activists involved in opposing 'race suicide' advocated both restrictions on immigration and pro-natal policies for women of 'desirable' race. While 'demographic winter' does not include a fear that those of 'uncivilised' races will soon outnumber 'civilised' ones, it does emphasise the importance of maintaining nationhood in the form of ethnic ancestry. If out-breeding occurs, however, advocates of 'demographic winter' assure their audiences that it will be religious people out-breeding the faithless. 'Pro-family' scholars of 'demographic winter' vigorously reject the notion that racism is driving their concern; rather, they say they are issuing a warning to the world of an impending crisis that will have far-reaching and detrimental effects.

'Pro-family' organisations acknowledge their political interest in this phenomenon to varying degrees: the more scholarly seek only to describe 'demographic winter,'

\footnotetext{
${ }^{44}$ Tatad, F. (1999) 'The Family and Population Control,' Remarks to the World Congress of Families II, November 15 1999, Geneva, November 14 - 17, available at http://www.worldcongress.org/wcf2_spkrs/wcf2 tadad.htm [last accessed 28/08/09].

${ }^{45}$ Carlson, A. (2003) 'World Population Trends and the Retreat from Marriage,' Speech to the Illinois Association of Scholars at Loyola University, Chicago, Illinois. The Howard Center, 5 April, 2003. Available at http://www.profam.org/docs/acc/thc_acc_loyola030405.htm? [last accessed 30/08/09].

${ }^{46}$ Tatad, op. cit.

${ }^{47}$ For more on this, see Rosen, C. (2004) Preaching Eugenics: Religious Leaders and the American Eugenics Movement (New York: Oxford University Press), and Black, E. (2003) War Against the Weak: Eugenics and America's Campaign to Create a Master Race (New York, London: Four Walls Eight Windows).
} 
whilst others openly encourage its use as part of the 'pro-family' arsenal against their opponents. In addition, leaders differ in their interpretations of how this impending catastrophe will impact on their movement and its relative influence in world affairs. Some portray the process as one that will be broadly devastating, yet others expect 'demographic winter' to usher in the eventual (ironically) evolutionary triumph of faith over secularism. Although 'demographic winter' has been broadly adopted in 'pro-family' circles, people in the movement vary as to their interpretations of what it means and their responses to it.

An example of the more scholarly approach described above is a speech entitled 'World Population in the $21^{\text {st }}$ Century: Last one out turn off the lights?' given in 1999 at the same WCF conference attended by Tatad. In this speech, 'pro-family' scholar Nicholas Eberstadt offered some demographic projections for the next one hundred years. In his 1999 description of what society will be like, he suggested that:

'... pervasive and prolonged sub-replacement fertility in a world of long life expectancy would presage a radical change in family structure along the lines of onechild China. For the first time in the human experience, there could be societies in which the only biological relatives for many people would be their ancestors. With sufficiently low fertility for just two generations, people with blood siblings and cousins would become the exception. Exactly how a society would operate under such conditions - how, for example, children would be socialized - is difficult to imagine. $^{48}$

Despite this assessment, Eberstadt does not suggest that long-term fertility decline is necessarily disastrous; rather he warns that the process of 'orderly global depopulation would require strange new adjustments. ${ }^{, 49}$ Eberstadt's prediction is an echo of the 'pro-family' fear of an increasingly individuated society, a social outcome which, as has already been shown, 'pro-family' organisations find deeply problematic. Rather than spell out the strange aspects of a cousin-less, sibling-less society with no aunts and uncles, this 'pro-family' demographer is content to let his

\footnotetext{
${ }^{48}$ Eberstadt, N. (1999) 'World Population in the $21^{\text {st }}$ Century: Last one out turn off the lights?' Remarks to the World Congress of Families II, Geneva, November 14 - 17 November 151999 , Available at http://www.worldcongress.org/wcf2_spkrs/wcf2_eberstadt.htm [30/08/09].

${ }^{49}$ Ibid (Emphasis in original).
} 
prediction of a childless and faithless future - the opposite of the fertile Christian family at the heart of the 'pro-family' vision - speak for him.

Few 'pro-family' commentators are so reserved in their evaluation of 'demographic winter.' Catastrophic assessments of how 'demographic winter' will affect societies abound in 'pro-family' texts. Some 'pro-family' authors focus on economic issues associated with ageing societies. Some commentators see intergenerational conflict as likely under conditions of depopulation, and others predict tensions as increased immigration impacts on social stability. One even suggests the possibility that some international conflicts can be explained in part by low birth rates. ${ }^{50}$ While some of the more far-fetched 'demographic winter' scenarios have not been widely picked up in 'pro-family' discourse, ageing and immigration have become important issues in 'pro-family' circles. I discuss each of these before turning to 'pro-family' explanations as to why 'demographic winter' has occurred.

'Pro-family' leaders stress the economic downturn they believe will be associated with declining fertility. As consumption decreases, say 'pro-family' economists, people in economies with shrinking populations will struggle to maintain their standards of living because relative to the elderly, the economically productive members of the population will be smaller. Economic stagnation is likely in Carlson's view, 'as the old inherit large parts of the earth.' ${ }^{51}$

Population ageing is a major aspect of 'demographic winter,' and the one perhaps most immediately worrisome for government policymakers. 'Pro-family' activists have seized upon this anxiety and offer a plethora of advice to governments as to how they might reverse this trend by the adoption of 'pro-family' policies. 'Profamily' leaders promise higher birth rates through the criminalisation of abortion,

\footnotetext{
${ }^{50}$ In an interview with CWA, for example, Don Feder suggests that Russia's declining population was a factor in its government's 2008 decision to invade neighbouring Georgia. Kleder, M. (2008) 'Russia, Georgia and Demographic Winter,' Interview with Don Feder, Concerned Women for America, 1 September 2008. Available at http://www.cwfa.org/articles/15721/CWA/misc /index.htm (6:05-7:40) [Last accessed 08/05/09]. See also Harry S. Dent's analysis of baby-boomer's consumption which he argues is driving the economy in 'Demographic Winter: the Decline of the Human Family (2008) SRB Documentary, LLC, Acuity Productions [DVD] (16:30-17:30).

${ }^{51}$ Carlson, A. (1999) 'Depopulation and the New World Social Order,' Keynote Address to the Australian Regional Conference of the World Congress of Families II, Melbourne, Australia, August 7, 1999. Available at http://www.profam.org/docs/acc/thc acc_depop.htm [last accessed 26/08/09].
} 
the reduction of tax burdens on one-income families, opposition to gay marriage and the promotion of home-schooling, to name a few.

Promoting a book called 'Gray Dawn' in 1999, Ruse says that the book explains how 'rapidly aging populations in the industrial countries' will bring about 'the collapse of medical and social pension systems and may eventually bring on intergenerational warfare. ${ }^{52}$ Dobson also sees declining fertility in stark terms, and blames society's hostility to families for what he sees as a very depressing future:

'The eventual result of this hostility to children and parents, as it spreads, will be a form of social suicide, leading to a world without springtime, regeneration, or the idealism of youth. Remaining will be an increasingly ageing community stumbling inevitably toward death and decay. ${ }^{53}$

Juxtaposing springtime, life and youth with winter, death and the elderly, 'demographic winter' is a highly political and emotionally charged appeal to people of reproductive age to resist this trend and have more children.

Although the elderly are routinely vilified in 'demographic winter' scenarios, euthanasia is not the answer to the ageing trap for 'pro-family' organisations. One Focus author does acknowledge the economic appeal of euthanasia, but condemns the practice as 'a moral evil and societal curse' which would not fix a country's economic problems anyway. ${ }^{54}$ Because of the 'devaluation of human life' that this author sees as inherent in the practice, 'far from solving the problem of excess elderly per worker, [euthanasia] introduces an undercurrent of death and fear throughout the country, outweighing any possible economic benefit. ${ }^{55}$ That this author is willing to weigh up what he sees as an absolute 'moral evil' against its measurable 'possible economic benefit' is an example of a growing trend in 'profamily' discourse away from a steadfast reliance on absolute moral certainty to win the day. I return to this theme later in the chapter.

\footnotetext{
${ }^{52}$ Ruse, A. (1999) 'Mainstream Media Increasingly Covers Emerging Depopulation Scare' Friday Fax, vol. 2, no. 41, Catholic Family and Human Rights Institute. Available at http://www.cfam.org/publications/id.104/pub_detail.asp [Last accessed 30/08/09].

${ }^{53}$ Dobson, J. (2007) 'Children are a blessing and a treasure,' Focus on the Family, 17 April, 2007. Available at http://www.citizenlink.org/focusaction/fofafeatures/A000006801.cfm [Accessed 30/08/09].

${ }^{54}$ Finger, op. cit.

55 Ibid.
} 
Immigration is also an inappropriate policy response to 'demographic winter,' say 'pro-family' groups. Seeking to bolster the number of young workers to support their ageing populations, many industrialised countries have rapidly increased the numbers of immigrants they allow to settle within their national borders. A number of 'pro-family' scholars claim that Europe is losing touch with its culture as European governments respond to their declining birth rates with increasing immigration. This trend is seen as a serious problem in 'pro-family' discourse, with Europe again emphasised as a worrisome litmus test for the cultural and economic deterioration these groups associate with fertility decline.

'Pro-family' intellectuals see immigration as detrimental to a nation's identity, arguing that nations need sufficiently high rates of reproduction to be 'racially and culturally connected' to their histories. ${ }^{56}$ Don Feder also makes this point, suggesting that as Europe takes in more and more immigrants their national character is changing. ${ }^{57}$ 'Within a few decades, he argues, 'England will no longer be England, and France will no longer be France... It could be 'the Islamic Republic of France. ${ }^{58}$ Feder is not alone in his efforts to capitalise on a rise in antiimmigration sentiment in Europe: European audiences have been treated to an increasing number of 'pro-family' speeches, visits and conferences in recent years. Anti-immigration sentiment may also be connected to 'pro-family' groups' opposition to globalization as a culturally homogenising force. ${ }^{59}$ That immigration increases the tendency towards cultural relativism may or may not be the case, but the appeal to national identity suggests that 'pro-family' leaders do seek a counterweight to the relativising effects of multiculturalism.

Crouse sees the problem of immigration in terms of immigrants' 'refusal to assimilate' into their new countries' cultures. In a 2005 article attacking first world

\footnotetext{
56 Ibid.

${ }^{57}$ Kleder, M. (2008) 'Russia, Georgia and Demographic Winter,' Interview with Don Feder, Concerned Women for America, 1 September 2008. Available at http://www.cwfa.org/articles/15721/CWA/misc/index.htm [Accessed 30/08/09].

${ }^{58}$ Ibid (this quote occurs between 7:50-8:30).

${ }^{59}$ Globalization, in this case through immigration, may be problematic for many religious conservatives, because it brings into stark relief the idea that 'diverse ways of living are largely human constructions,' as Beyer puts it. Beyer, P. (1994) 'Religion and Globalization,' Sage, p. 2.
} 
feminists, she stresses the incompatibility of this feminist-inspired Western culture with the sensibilities of its new (non-Western) immigrants:

'It is ironic that the feminist leaders of advanced developed nations wish to spread their culture of abortion to all corners of the world; these privileged elites come from countries that are being so depopulated by low birth rates that they have had to import labor from Third World nations to keep their economies functioning. The new arrivals are refusing to assimilate into the decadent cultures of their host countries. In the end, Western culture, especially in Europe, is being threatened with extinction. ${ }^{, 60}$

In this assessment, Crouse again discusses abortion as a culture that harms nationhood (as she does in her 2002 article quoted earlier in the chapter), but this time makes an explicit connection with immigration. Crouse is not the only observer who sees irony in this situation: in 'pro-family' efforts to save 'European culture' from extinction, these organisations are trying to rescue what they elsewhere deride as a haven of secularism, feminism, and liberalism. That Crouse sees immigrants' lack of assimilation as connected to the extinction of nationhood is significant, as it raises the question of whether successful integration into new cultures is even desirable in the 'pro-family' view. If Western culture were less offensive to its new citizens, Crouse would still be likely to reject immigration as a plausible policy response to population ageing. Although she appears to side with the 'new arrivals' - and hence with Islam - against Western depravity, Crouse is still uneasy about the situation she is describing.

Crouse is not the only one siding with immigrants. Turning his focus to the US, the Howard Center's Bryce Christensen's view of new immigrants is also somewhat positive. After warning that the Social Security and Medicare demands of ageing baby-boomers will demand the influx of as many as five million new immigrants per year to the US, ${ }^{61}$ Christenson considers the implications of this increase in immigration. He considers the relatively more religious and 'pro-family' Mexican

\footnotetext{
${ }^{60}$ Crouse, J. S. (2005) 'A Contest of Wills: Whose worldview about women's well-being will ultimately prevail?' Concerned Women for America, 1 March, 2005. Available at http://www.cwfa.org/articledisplay .asp?id=7573\&department=BLI\&categoryid=nation [Last accessed 01/06/09].

${ }^{61}$ Christensen, B. (2006) 'Confronting the Family Implications of the Immigration Debate: Remembering the Laws of Man y las Leyes de la Naturaleza.' The Family in America vol. 20, no. 9. The Howard Center, September 2006. Available at http://www.profam.org/pub/fia/fia.2009.htm?search=demographic\% 20winter\&opt=EXACT [last accessed 03/06/09].
} 
immigrants already in the US to be a desirable addition to a country that he sees as drifting away from religious and traditional values. The immigration 'problem,' he writes, 'is about us, not them.' Had the 'natural laws of the home economy' not been flouted, Christenson writes, the US would not need immigrants to sustain its ageing population.

Moreover, say 'pro-family' experts, immigration causes the removal of productive citizens from their homes in the developing world. In this way, 'pro-family' analysts argue that 'demographic winter' adds to the problems of people in developing countries. ${ }^{62}$ Maria Sophia Aguirre, interviewed in Demographic Winter, suggests that immigration is a problem for developing countries for two main reasons. Firstly, she suggests that the labour productivity in developing countries goes down as its productive citizens leave. Secondly, as the majority of workers who leave are men, she suggests that there is a 'human capital' cost, because more children from developing countries grow up without their fathers. Spanish economics professor Alban d'Entremont has this to say about the situation:

'It would be ironic, and it would be very unjust, that the poor countries should come to bail out the rich countries because the rich countries have been delinquent in doing their homework, in keeping up stable and strong families, and then they themselves would lose theirs, bailing us out. ${ }^{, 63}$

Immigration, in this view, is not just an economic issue, it is a moral one. The policies of delinquent governments have helped to produce fatherless, dysfunctional families at home, and the economic incentives they have created will produce fatherless families in third world countries by a different means.

Not far beneath the surface, 'demographic winter' is an affirmation of the positive role of religion in society. 'Demographic winter' discourse is connected to the trend away from explicitly religious references in most 'pro-family' discourse. The two trends are linked in different ways: deductively, by conflating children and religion with selflessness, and contrasting these with faithlessness and materialism; statistically, with children being disproportionately born to people of faith; and

\footnotetext{
${ }^{62}$ Maria Sophia Aguirre and Alban d'Entremont, interviewed in Demographic Winter: the Decline of the Human Family (2008) SRB Documentary, LLC, Acuity Productions [DVD] (7:30-8:00)

${ }^{63}$ Ibid.
} 
culturally, through increasing individualism and the rejection of conservative Christian sex morality.

In a speech in 2003, Carlson makes it clear that the movement away from religion is the 'key variable' in understanding fertility decline. ${ }^{64}$ In Carlson's view, 'demographic winter' should not really be considered as something new: it is simply a continuation of the Western world's long term shift away from Christian morality. Where 'responsibility, sacrifice, altruism, and sanctity of long-term commitments' used to be paramount, Carlson says, society is now moving towards the prioritisation of 'a militant "secular individualism" focused on the desires of the self. ${ }^{65}$

Fagan concurs, observing that this trend can be seen where religious and nonreligious family sizes are compared. 'The future,' he argues, 'belongs to those who have children. ${ }^{66}$ This point is reiterated a number of times in Demographic Winter. Echoing this and Crouse's warning to Europe, Phillip Longman, a prominent speaker in the film, states that 'people, who for lack of faith, don't go forth and multiply, are on the road to extinction. ${ }^{67}$

HLI makes the connection between the retreat from religion and declining fertility quite explicit. Promoting a CD talk by HLI's founder Paul Marx, entitled 'The World Sex Mess Confirms Catholic Teaching around the World,' HLI offers listeners the opportunity to

'travel around the world with Fr. Marx as he explains how the world's population crisis-and by that I mean the declining populations of so many countries-is

\footnotetext{
${ }^{64}$ Carlson, A. (2003) 'World Population Trends and the Retreat from Marriage,' Speech to the Illinois Association of Scholars at Loyola University, Chicago, Illinois. The Howard Center, 5 April, 2003. Available at http://www.profam.org/docs/acc/thc_acc_loyola030405.htm [last accessed 30/08/09].

${ }^{65}$ Ibid.

${ }^{66}$ Fagan, P. (2008) 'Family Research Center's Family Policy Lecture: Demographic Winter Policy Discussion,' available at http://www.frc.org/get.cfm?i=PL08E02 [last accessed 29/05/09] (44:4545:00).

${ }^{67}$ Phillip Longman interviewed in Demographic Winter: the Decline of the Human Family (2008) SRB Documentary, LLC, Acuity Productions [DVD] (46:50-47:05).
} 
directly linked to the world's rejection of traditional Catholic teachings on abortion and birth control. ${ }^{68}$

Though 'the world' is responsible for rejecting Catholicism in this text, external enemies are still at large in HLI's framework. The advertisement continues:

'The Church is thriving [in Africa], but forces from wealthy Western nations are trying to bring the culture of death to this life-loving continent by injecting it with contraception, abortifacients, and destructive sex education. ${ }^{69}$

Unlike other 'pro-family' organisations, HLI remains reluctant to fully translate its discussion of declining population into terms which see the enemy as internal to society, rather than external to it.

This movement away from religion has spawned a number of different drivers of demographic winter, say 'pro-family' groups. Sometimes the blame for declining fertility is assigned to the absence of religion from government. 'Pro-family' organisations cite 'anti-family' economic policies, mass state education, and legal tolerance of homosexuality and abortion as leading causes of 'demographic winter.' At other times 'pro-family' leaders hold the diminishing role of religion in industrialised society responsible for people's choices to limit their family size. In this way, 'pro-family' groups see the absence of a public religious culture as leading to 'demographic winter' through an increase in selfishness, individualism and materialism, and the diminishing status of children in society.

'Pro-family' activists acknowledge the role that tax laws and welfare play in influencing the way families are formed. Over time, 'pro-family' scholars trace a movement away from an economic system that rewards the one-income family with many children to one that encourages two-income parents with smaller families. Dobson recommends that child-rearing is already 'bone-wearying and timeconsuming work,' so those that choose to do so should not face 'backbreaking taxes and family-unfriendly policies from the government. ${ }^{70}$ While most 'pro-family'

\footnotetext{
${ }^{68}$ Advertisement at the end of HLI's Special Report, no. 28, April 2008, available through www.hli.org. [last accessed [20/08/08]. 
leaders see family formation as a natural human urge, which is not necessarily dependent on economic policies, they nevertheless argue that government incentives have a significant impact on young couples' decisions about their families.

In 2003, Carlson makes a similar complaint about the way that governments in industrialised economies disincentivise marriage and child-rearing. In his attempt to explain governments' role in promoting fertility, he suggests that 'family creation as an expression of religious belief' is not sufficient to bring about a change in downward population trends. Being religious is not enough; the decision to start a family 'also requires a favorable policy environment.' ${ }^{71} \mathrm{He}$ highlights the importance of tax law in promoting marriage and childrearing, and offers the following view of transfer payments to low-income parents:

"The "Chicago School" also shows how state-provided welfare benefits can disrupt the natural economic gains of marriage. So can easier divorce, since women will only commit to more children and housework, and forego career advancement, if they are reasonably certain that their households will not dissolve. ${ }^{, 72}$

'Pro-family' economists concur. In his discussion of population decline during a discussion with Carlson and Fagan on the documentary Demographic Winter, economist John Mueller suggests that the best policy response to the trend (after criminalising abortion) is to 'downsize transfer payments' and institute a 'broad base low rate income tax. ${ }^{, 73}$

Broadly agreed upon is the rejection of the 'Swedish model.' Though Sweden's birth rate is higher than that of most European countries, it is still unsatisfactorily low in the view of 'pro-family' activists. In addition, stimuli intended to increase the number of Swedish children are derided as coercive and radical by 'pro-family'

\footnotetext{
${ }^{71}$ Carlson, A. (2003) 'World Population Trends and the Retreat from Marriage,' Speech to the Illinois Association of Scholars at Loyola University, Chicago, Illinois. The Howard Center, 5 April, 2003. Available at http://www.profam.org/docs/acc/thc acc loyola030405.htm [last accessed 30/08/09].

${ }^{72}$ Ibid.

${ }^{73}$ Mueller, J. (2008) 'Family Research Center's Family Policy Lecture: Demographic Winter Policy Discussion,' available at http://www.frc.org/get.cfm?i=PL08E02 [last accessed 29/05/09] (Mueller makes these statements between 27:30-28:30).
} 
intellectuals. ${ }^{74}$ Sweden plays an interesting role in 'pro-family' texts as the antithesis of the conservative Christian development model. Despite Sweden's obvious success in terms of the economic well-being of its citizens, 'pro-family' activists use Sweden as an example of how not to modernise. In terms of preventing 'demographic winter,' 'pro-family' authority Philip Longman suggests there is 'not much to say for the Swedish model. ${ }^{, 75}$ 'Pro-family' groups portray Sweden as 'ultra-liberal, ${ }^{76}$ with socialism having 'triumphed over the home. ${ }^{77}$ The country's (as yet) unsuccessful efforts to increase its birth rate to 2.1, despite its generous parental leave policies, are cited by 'pro-family' organisations as the final nail in the coffin of the secular welfare state.

Speaking on 'Sweden and the Failure of European Family Policy' in Prague, Carlson declares 'that a social order that does not reproduce itself will be replaced by another... the Swedish model works no better than any other social welfare model in countering depopulation. ${ }^{78}$ Part of the explanation for this, Carlson suggests, is because liberal economies in general create doubts in women's minds as to whether they should devote their lives to raising children. Another reason for declining fertility rates, says Carlson, are Europe's efforts to promote gender equality, which in his view are an attempt to cure a problem created by feminism with feminist ideas. In explaining why the US birth rate has not declined as far as Europe's, Carlson suggests that Americans are 'generally held less hostage to the anti-natal dogmas of pure "gender equality" than are the "Swedenized"

\footnotetext{
${ }^{74}$ Of the requirement that fathers take paid parental leave, for example, Carlson notes that 'even some of the more coercive aspects of Sweden's parents insurance program... have their human side: it turns out that Swedish fathers have a strong preference toward taking their parental leave during Sweden's elk-hunting season!' Carlson, A. (2005) 'Sweden and the Failure of European Family Policy,' A lecture for the Civics Institute, the Senate Building, Prague, Czech Republic. The Howard Center, 27 April 2005. See http://www.profam.org/docs/acc/thc.acc.050727.fof.sweden.htm? [last accessed 30/08/09].

${ }^{75}$ Phillip Longman interviewed in Demographic Winter: the Decline of the Human Family (2008) SRB Documentary, LLC, Acuity Productions [DVD] (00:45-00:49)

${ }^{76}$ Dobson, J. (2006) 'The Battles Ahead,' Focus on the Family, 4 January 2006, available at http:// www.citizenlink.org/focusaction/fofafeatures/A000006835.cfm [last accessed 30/08/09].

${ }^{77}$ Carlson, A. (2004) 'Marriage and Procreation: On Children As The First Purpose of Marriage,' Family Policy Lecture, Family Research Council, October 20, 2004. See http://www.frc.org/get.cfm?i=PL04J01 [30/08/09].

${ }^{78}$ This thesis is not the place to judge the validity or otherwise of this statement. Carlson, A. (2005) 'Sweden and the Failure of European Family Policy,' A lecture for the Civics Institute, the Senate Building, Prague, Czech Republic. The Howard Center, 27 April 2005. Available at http://www.profam.org/docs/acc/thc.acc.050727.fof.sweden.htm? [last accessed 30/08/09].
} 
Europeans. ${ }^{79}$ Sweden's efforts to increase its birth rate - and Europe's by association - are thus doomed to fail. In Carlson's view, this is not just because Sweden has abandoned tradition and religion as guiding economic principles, but because its policy makers deny the innate differences between men and women. This denial, he argues, 'can only result in violations of human nature, doing particular harm to existing and potential children. ${ }^{80}$ Because its governments are infused with feminist sentiments and condone homosexuality and abortion, 'profamily' activists confidently predict that Sweden's pro-natalist efforts will ultimately fail to prevent fertility decline.

Europe is emerging as a new front line in the 'pro-family' battle for the 'natural family.' Instead of depicting Europe as 'lost' as was frequently the case in earlier texts, interest in 'rescuing' Europe from a secular and childless fate is increasingly common in 'pro-family' discourse. In a flyer for the fourth WCF in 2007, the Howard Center invites those who 'believe in the family' to attend the congress, stating that

'Europe is the battlefield and Poland is pivotal. Through demographic winter and the rule of an anti-family elite, Europe is almost lost to family values. The loss of Europe will have a devastating impact on the family in the Americas, Asia and Africa, as well as in international forums. Poland is a bastion of tradition, faith and family. WCF IV will draw pro-family advocates from across the European continent in what could be the beginning of a pro-family renaissance. ${ }^{81}$

Evoking images of war, tribulation and rebirth, the choice of Poland in 2007 (and indeed the Netherlands in 2009) as host countries for the WCF shows a new-found interest in Europe as a target for increased 'pro-family' activism. Europe's demographic situation undoubtedly plays a part in this. Whether 'pro-family' organisations seek to use Europe as a warning, or to 'save' Europe from 'extinction' is not clear. ${ }^{82}$

\footnotetext{
${ }^{79}$ Ibid.

${ }^{80}$ Ibid.

${ }^{81}$ The Howard Center (2007) 'If you believe in the family, come to Warsaw,' World Congress of Families IV flyer, accessed at www.worldcongress.org/WCF4/wcf4.nmx0701.htm [last accessed 13/07/09].

${ }^{82}$ Christian Right observer Kathryn Joyce suggests that 'demographic winter' is part of the 'profamily' strategy to give its ideology a foothold in the European political scene. Joyce, K. (2008) 'Missing: The "Right" Babies,' The Nation, March 3, 2008.
} 
'Demographic winter' has proved an opportunity for 'pro-family' activists to show old foes in a new and negative light. That homosexuality, contraception and abortion are cited by 'pro-family' organisations as drivers of declining fertility will come as no surprise to observers of the US Christian Right. What is interesting, however, is that 'demographic winter' has enabled 'pro-family' organisations to extend their criticism of practices they oppose to developed countries, such as Europe and Japan. 'Look to Europe,' suggest 'pro-family' organisations in their efforts to prevent gay marriage in the US. In the words of one Focus on the Family booklet:

'Marriage produces and raises the next generation of humanity, which every society needs. If you don't believe this is a need, look at the current depopulation trends in much of Europe. Governments there are realizing that a dearth of childbearing couples raises many serious social and economic issues. ${ }^{, 83}$

Europe, generally seen as sympathetic to homosexuality in 'pro-family' circles, has only itself to blame for its low fertility rates in this author's view.

Like homosexuality, abortion is similarly targeted as a cause of declining fertility, and criminalisation of abortion is usually the first advice given to reverse 'demographic winter.' Abortion causes 'demographic winter' in practical as well as well as cultural terms in 'pro-family' discourse. 'By tolerating abortion of unborn children by the millions, particularly in North America, Europe and China,' one Focus author writes,

"we have first of all eliminated a large group of young citizens who now and in the future could be helping to support our elderly. Second, we have instilled a "culture of death" that has taken us well beyond the notion of reasonably limiting family sizes, to becoming "anti-child" altogether. ${ }^{, 84}$

Seeing abortion as responsible for an alleged 'anti-child' culture of industrialised countries as well as driving down the overall numbers of young people, 'profamily' organisations have expanded the arguments they use to oppose the practice.

\footnotetext{
${ }^{83}$ Stanton, G. T. (2005) 'Ten Persuasive Answers to the question... Why not gay marriage?' Focus on the Family, http://www.citizenlink.org/pdfs/fosi/marriage/Why_Not_Gay_Marriage_Bklt.pdf [last accessed 13/06/09].

${ }^{84}$ Finger, op. cit.
} 
Another driver for fertility reduction identified by Carlson is 'mass state education.' This too is connected to the movement away from religion, say 'pro-family' activists, in that state schooling establishes state moralities in the place of traditional ones. Carlson sees state education as a major driver behind reduced fertility, citing a 1982 study by demographer John Caldwell as evidence for this position. Caldwell's view is that state schooling has programmed new generations of children against 'the old family morality,' with the result that societies cannot maintain 'stable high fertility beyond two generations of mass schooling.' ${ }^{85}$ As a solution to 'demographic winter,' then, 'pro-family' policy solutions to combat 'demographic winter' (according to Patrick Fagan) are to 'retain family control over education,' and to 'build an intellectual and organisational infrastructure that is forthrightly pronatalist. ${ }^{86}$

When religion is addressed in discussions of 'demographic winter,' such as in these arguments against state-schooling, abortion and homosexuality, it is discussed as an empirical variable, and associated with a desirable social outcome. In connecting 'demographic winter' with older conservative Christian concerns, 'pro-family' groups can now depict the removal of old foes as new and statistically 'proven' policy solutions. If this seems like a sleight of hand however, it is not. As noted above, Carlson and his colleagues do not disguise their affection for religion as a public good. In his 2003 speech on world population trends, Carlson openly states that the other variables that might explain fertility decline are just a list of secondary causes deriving from the removal of religion from public life; all his speeches and articles on this subject identify the movement away from Christianity as the most crucial aspect of depopulation. This he sees as the key source of trouble faced in the economically developed world, and increased religious observance is the solution. Industrial societies' rejection of religion is not only wrong in itself; in Carlson's view, it is harming people in a measurable way.

\footnotetext{
${ }^{85}$ John C. Caldwell, quoted in Carlson, A. (2003) 'World Population Trends and the Retreat from Marriage,' Speech to the Illinois Association of Scholars at Loyola University, Chicago, Illinois. The Howard Center, 5 April, 2003. See http://www.profam.org/docs/acc/thc_acc_loyola030405.htm [last accessed 30/08/09].

${ }^{86}$ Carlson (2008) 'Family Research Center's Family Policy Lecture: Demographic Winter Policy Discussion,' available at http://www.frc.org/get.cfm?i=PL08E02 [last accessed 29/05/09] (12:2512:52).
} 
One of the main reasons that the absence of religion causes 'demographic winter,' say 'pro-family' organisations, is that without religion as a moral guide, individuals become self-serving and materialistic. No longer seeking to be loving parents, 'profamily' authors suggest, couples opt out of having children because they see no reason to subject themselves to work that has no obvious material gratification. 'Pro-family' intellectuals argue that not only do people live apart from their families in today's society, their attitudes, beliefs and values have changed so significantly that individual successes and material wealth are now valued over family life. Recognising this, many 'pro-family' commentators suggest that changes to the economy and in the political sphere (the structural changes described above) would have been unlikely to have had such an enormous impact on family life in the absence of cultural changes influencing the ideologies of individuals. ${ }^{87}$

These changes have been so momentous that in a discussion of how 'pro-family' advocates might reverse 'demographic winter,' Carlson suggests that 'science is on our side... but the human heart.... culture... is no longer on our side. ${ }^{88}$ This marks an important turning point away from asserting a 'pro-family' 'moral majority,' at least in the industrialised world. Carlson sees reality (as measured by social science indices) as confirming his political views, and yet diverging from most people's heartfelt ideas about how the world is and should be. ${ }^{89}$ This goes some way to explaining the enormous effort 'pro-family' organisations are making to find evidence to support their positions outside the religious and traditional realm: they now see social science as their best foothold in an increasingly 'anti-family' public sphere.

In a discussion of the film Demographic Winter, Carlson suggests that many of the issues that the documentary addresses - women working, divorce, affluence - are symptoms as well as causes of fertility decline. The real reason for declining

\footnotetext{
${ }^{87}$ Norval Glenn, interviewed in Demographic Winter: the Decline of the Human Family (2008) SRB Documentary, LLC, Acuity Productions [DVD] (20:20-20:45)

${ }^{88}$ Carlson, A. (2008) 'Family Research Center's Family Policy Lecture: Demographic Winter Policy Discussion,' available at http://www.frc.org/get.cfm?i=PL08E02 [last accessed 30/08/09] (reference occurs between 64:10 - 64:30)

${ }^{89}$ This is in many ways the reverse of Christian Right arguments as the 'moral majority': they are now the experts, and the public is not on their side.
} 
fertility, he suggests, is to be found in the changing world of politics and ideas. ${ }^{90}$ Patrick Fagan concurs, and puts much of the blame for this on the world of academia. Universities, suggests Fagan, face a huge problem of political correctness, a lack of courage, and a reluctance to discuss contraceptives and abortion, which he sums up as a 'huge denial' and an 'unwillingness to look at the truth. $^{91}$

Similarly, Dobson also sees the source of fertility decline in the changing ideology and culture of industrialised societies. He suggests that the selfishness inherent in modern societies stops couples from having children. Acknowledging that raising children can be extremely difficult at the best of times, he sees the decision to have a child nowadays as a 'counter-cultural' act. In a 2007 article, Dobson states that 'the investment in children is the antithesis of our society's self-centered, "me first" environment that so often aborts its babies or neglects its young. ${ }^{92} \mathrm{He}$ suggests that childless adults have huge economic appeal as consumers and workers, with more disposable income than their parenting peers. Contemporary society, his article suggests, tells people that children are a 'burden and an inconvenience,' part of a major shift from a society of families to one that is child-free. ${ }^{93}$ Moreover, in Dobson's view, parents and children are not just disappearing from society, they are actively scorned as 'breeders' and 'spawn' in contemporary culture. ${ }^{94}$ Making exceptions for those who cannot physically have children, Dobson takes issue with this culture and its 'child-free adults,' ultimately stating that 'chosen childlessness must be named as moral rebellion. ${ }^{95} \mathrm{He}$ and his colleagues see children as the way for adults to become good people, by virtue of the way that parenthood forces otherregarding behaviour.

Dobson is not alone in his contention that the place of children in society has changed. Parents, families and children, say 'pro-family' groups, are now objects of

\footnotetext{
${ }^{90}$ Carlson, A. (2008) 'Family Research Center's Family Policy Lecture: Demographic Winter Policy Discussion,' available at http://www.frc.org/get.cfm?i=PL08E02 [last accessed 30/08/09] (5:45-6:55, 63:50-64:00).

${ }^{91}$ Fagan, in ibid, (62:30-63:00).

${ }^{92}$ Dobson, J. (2007) 'Children are a blessing and a treasure,' Focus on the Family, 17 April, 2007. Available at http://www.citizenlink.org/focusaction/fofafeatures/A000006801.cfm [Accessed 30/08/09].

${ }_{93}^{93}$ Ibid.

${ }^{94}$ Ibid.

${ }^{95}$ Ibid.
} 
derision, and the well-being of children now takes second place to adult fulfilment. Kay Hymowitz, interviewed in Demographic Winter suggests that industrial societies tell people that 'the happiness of adults is so much more important than the well-being of children." 96 Another interviewee, sociologist Steven Nock, suggests that 'adults have an obligation to children generally. ${ }^{97}$ Though he does not discuss what this means, Nock suggests that adults no longer recognise this obligation, and for this reason 'things are unhappy in a general sense.'

Focus writer Glenn Stanton also takes this perspective, positing a link between moral decay and fertility decline. Stanton sees a waning of 'selflessness, sacrifice and maturity' and a dearth of children being born as reinforcing each other in a vicious circle. He is concerned that

'Rather than learning that healthy adulthood requires the consideration of others, many twenty- and thirty-somethings seem to view life as "all about me" as they pursue gadgets, fun, money and peer approval. This is at crosspurposes to the selfsacrifice and commitment necessary for marriage and child-rearing. ${ }^{98}$

'Pro-family' groups reject the idea that people can be socialized well through relationships that exist outside of family life. Echoing Eberstadt's consideration that children need aunts, uncles, cousins and siblings to be properly socialised, Fagan explains that children from large families learn to give. ${ }^{99}$ Again 'pro-family' groups offer family life - large family life - as the antidote to all forms of anti-social behaviour.

HLI also offers an opinion on the link between reduced fertility and individualism. In a trip to Mexico, HLI's Euteneuer criticises what he sees as selfishness in choosing to have smaller families, complaining that couples

\footnotetext{
${ }^{96}$ Kay Hymowitz, interviewed in Demographic Winter: the Decline of the Human Family (2008) SRB Documentary, LLC, Acuity Productions [DVD] (30:50-31:10).

${ }^{97}$ Steven Nock interviewed in Demographic Winter: the Decline of the Human Family (2008) SRB Documentary, LLC, Acuity Productions [DVD] (30:20-30:35).

${ }^{98}$ Stanton, G. T. (2007) 'Family Formation Trends and Analysis: US Overview 2007. Children: the health of growing up in America' Focus on the Family, p. 1. Available at http://www.citizenlink.org/pdfs/fosi/marriage/07_Family_Formation_Trends_Children.pdf [last accessed 30/08/09].

${ }^{99}$ Fagan, P. (2008) 'Family Research Center's Family Policy Lecture: Demographic Winter Policy Discussion,' available at http://www.frc.org/get.cfm?i=PL08E02 [last accessed 30/08/09] (45:15).
} 
'opt for lifestyles that exclude or minimize children, and the practice of divorce becomes regularized and justified for the self-fulfilment of parents with no thought of its effect on children., ${ }^{100}$

Framing small families as a materialistic lifestyle choice, as opposed to what in practice is likely to incorporate a far more complicated set of values and issues, HLI sees the 'contraceptive mentality' as a package that promotes this kind of 'Porsche versus pregnancy' calculus. Euteneuer goes on to advise his 'pro-life' colleagues that

'...there are always three inevitable, I would say, infallible, consequences of the contraceptive mentality when it permeates a society long enough-and I wish all prolifers recognized these consequences as well:

1. A precipitous lowering of the fertility rate of a country;

2. An increase in abortion (whether legal or illegal) and the legalization of it where it is not yet legal; and worst of all,

3. The formation of selfishness in a populace. ${ }^{101}$

Euteneuer links these consequences in a causal chain, in which the worst consequence - selfishness - is the social outcome of adopting secular ideas about sexuality and reproduction.

The pursuit of money and material things is disdained in a number of different 'profamily' texts. Prosperity is understood as a correlate of low fertility both in terms of couple's financial choices to delay (or forgo) childbearing, and also in terms of the inverse relationship between a country's level of economic development and its fertility rate. This challenges the pursuit of money as a means of success, and deeply problematises the notion - central to the Republican Party platform - of personal financial responsibility. Dobson suggests that older generations should advise younger married couples to become parents as soon as possible, rather than "waiting for all of their financial dreams and aspirations to be realized., ${ }^{102}$ And as 'pro-family' activists accept, young couples in industrialised countries today face

\footnotetext{
${ }^{100}$ Euteneuer, T. J. (2004) 'Pro-Life Missionary Trip: Mexico,' Human Life International, March 29, 2004. Accessed at http://www.hli.org/mission_mexico_2004.html [last accessed 21/12/06]. ${ }^{101}$ Ibid.

${ }^{102}$ Dobson, J. (2007) 'Children are a blessing and a treasure,' Focus on the Family Action, 17 April, 2007. Available at http://www.citizenlink.org/focusaction/fofafeatures/A000006801.cfm [Accessed 01/06/09].
} 
'stark choices' when it comes to deciding when or whether to start a family. They can either 'live like kings,' or choose to have children, which is acknowledged as a 'relatively tough life, economically.' ${ }^{103}$ Still, 'pro-family' authors consistently state their preference for people to have a difficult financial life and a large family, characterizing childless couples who seek to delay the financial hindrance of childrearing as greedy, idle and un-Christian.

Reviewing a study on why American women remain childless in 2001, CWA considers the decision not to have children as a lazy one. The study's conclusion acknowledges that environmental issues and career advancement have an impact on peoples' decisions, but concludes that 'most childless couples simply have no desire for children or do not think they would be suitable parents.' This CWA translates as follows: 'in other words, they simply can't be bothered.' ${ }^{104}$ Again, choice and individual responsibility - demonstrated in this case by people's concern that they would be poor parents - is given short shrift.

Carlson offers us some insight as to why 'pro-family' intellectuals are so happy to move away from a focus on individual responsibility and choice in favour of blanket pro-natalism. He suggests that it is the social view of children that is at stake; personal choice has less to do with the matter than people are led to believe. He writes that

'It is important to note that the values of the new secular order, despite the rhetoric, do not in fact center on "freedom" and "choice." Rather, the evidence suggests that those are transitional arguments, masking a new and quite negative view of children. $^{105}$

Carlson sees the current 'secular order' as one in which children are commodified to some degree: they are either avoided as an economic burden or demanded to fulfil a lifestyle choice. Thus even the choice to have children is problematic to

\footnotetext{
${ }^{103}$ Fagan, P. (2008) 'Family Research Center's Family Policy Lecture: Demographic Winter Policy Discussion,' available at http://www.frc.org/get.cfm?i=PL08E02 [last accessed 29/05/09] (40:0041:30).

${ }^{104}$ CWA (2001) 'Apathy \& Childlessness' Concerned Women for America, 4 December 2001. Available at http://www.cwfa.org/articles/807/BLI/dotcommentary/index.htm [last accessed 30/08/09].

${ }^{105}$ Carlson, A. (2003) 'World Population Trends and the Retreat from Marriage,' Speech to the Illinois Association of Scholars at Loyola University, Chicago, Illinois. The Howard Center, 5 April, 2003. See http://www.profam.org/docs/acc/thc acc loyola030405.htm [last accessed 30/08/09].
} 
Carlson, because it is now privately made. As he puts it: "those who choose to parent now do so "to satisfy their private needs," rather than to meet religious, family, or communal obligations. ${ }^{106}$ He bemoans a society in which childrearing is merely the realisation of a consumption preference: 'some people have poodle dogs, others have children,' as he puts it. ${ }^{107}$ Having reproductive choice, rather than making all pregnancies 'wanted,' is seen as part of a general anti-child worldview.

Those 'pro-family' authors who discuss reproductive choice in this way see it as a running counter to 'pro-family' ideas about the role of God in conception. As Dobson puts it, 'lifestyle childlessness... is a wilful rejection of God's procreative purpose for marriage. ${ }^{108}$ The choice to have children, or not to have them, becomes a self-referential exercise that has nothing to do with God. In Carlson's words, fertility is now in the domain of the 'individual's secular conscience. ${ }^{109}$ Perhaps most importantly, reproductive choice is part of an increasingly common relativistic value set that 'pro-family' groups find intolerable. 'Pro-family' intellectuals posit that in conferring couples (or women) the choice to have children or not, altruism is no longer possible: parents do not have the ability to sacrifice their own happiness for that of their families, because such a sacrifice only makes sense outside the context of choice. Carlson suggests that societies are moving away from the values 'long affirmed by Christian teaching... responsibility, sacrifice, altruism, and [the] sanctity of long-term commitments... and toward a militant secular individualism.' 110 'Demographic winter,' in this light, is just a depressing byproduct of this shift. Not surprisingly, Carlson sees the key 'pro-family' response to 'demographic winter' as cultural rather than economic or political. He calls for the launching of 'a counter-revolution in values, which welcomes children under the banner of the natural family.' 111

\footnotetext{
106 Ibid.

${ }^{107}$ Carlson, A. (2005) 'Defining Family Friendly,' Remarks for a public dialogue co-sponsored by the Sutherland Institute and the Hinkley Institute of Politics, The University of Utah, 23 September 2005. See http://www.profam.org/docs/acc/thc.acc.dfu.050923.htm?search [last accessed 29/07/09]. ${ }^{108}$ Dobson, J. (2007) 'Children are a blessing and a treasure,' Focus on the Family, 17 April, 2007. See http://www.citizenlink.org/focusaction/fofafeatures/A000006801.cfm [Accessed 01/06/09]. ${ }^{109}$ Carlson, A. (2003) 'World Population Trends and the Retreat from Marriage,' Speech to the Illinois Association of Scholars at Loyola University, Chicago, Illinois. The Howard Center, 5 April, 2003. See http://www.profam.org/docs/acc/thc_acc_loyola030405.htm [last accessed 30/08/09]. ${ }^{110}$ Ibid.

${ }^{111}$ Carlson (2008) 'Family Research Center's Family Policy Lecture: Demographic Winter Policy Discussion.' See http://www.frc.org/get.cfm?i=PL08E02 [last accessed 30/08/09] (12:55-13:05).
} 


\section{Part II: Tensions}

'Demographic winter' is an idea that has been broadly picked up by 'pro-family' activists and has enormous potential to broaden the movement's appeal. Many countries in the industrialised world are indeed experiencing a 'birth dearth,' which in conjunction with faltering economies makes them ripe with potential for a wellorganised pro-natalist, 'traditionalist' movement. ${ }^{112}$ In this context, it is unsurprising that US 'pro-family' organisations seek to fill that role. Yet 'demographic winter' brings to light a number of tensions between competing 'profamily' views of the world. I highlight three.

\section{To prosper or not to prosper, that is the question}

Within the framework of 'demographic winter' sits the premise that affluence and family size are inversely related. This connection is made in a number of ways. Statistically, 'pro-family' social scientists measure income against fertility at the level of individual families, and in cross-country comparisons, and find that a negative relationship is produced in most cases. Others note the tough economic futures faced by young couples, and empathise to some degree with the enormity of the consequences of the decisions that they have to make. The relationship is also explained in terms of social norms in modern societies: the industrial world, "profamily' intellectuals claim, is actively 'anti-child.' Weyrich, in writing that life is about more than the acquisition of 'more stuff,' puts a distinctly anti-materialistic spin on this.

Yet on the other hand, 'demographic winter' is an appeal to maintain economic well-being through consumption. As Harry S. Dent reminds us, it is consumption that drives the earnings of companies. 'Demographic winter' scenarios rely on a crashing economy, produced by the combination of an ageing population with a sharp decline in consumption. More babies are required not just as a work force, but as a cohort of consumers to avoid the prolonged stagnation of the economy as babyboomers retire. If people are not afraid of this economic forecast, 'demographic

\footnotetext{
${ }^{112}$ See Gallaher, C. (2004) 'The Religious Right Reacts to Globalization,' in Tétrault, M. A. and R. A. Denemark (eds.) Gods, Guns and Globalization: Religious Radicalism and International Political Economy, International Political Economy Yearbook, vol. 13 (London: Lynne Rienner) for more on this.
} 
winter' loses a lot of its sting. Just as 'pro-family' groups are starting to suggest that capitalism needs to be restrained so that it better tends to the needs of families, they are also relying on the consumption appetite of the next generation to save it. Do 'pro-family' organisations want young people to prosper and consume in a materialistic manner, or do they want young people to have a 'relatively tough life'?

As we have seen with other 'pro-family' issues, 'demographic winter' turns development on its head. The global South is now used by proponents of 'demographic winter' to cast light on the problems of the West. Affluence as a goal of development is called into question. Yet there is little evidence that 'pro-family' groups are rhetorically moving away from advocacy for flat taxes and free trade, with economic growth as a major overall goal. Rather these economic policies are supported because of their supposedly beneficial impact on increasing the size of families. Families, I suggest, are the basis of 'the new conservatism' as advocated by Weyrich and others. ${ }^{113}$ 'Natural families' and fertility trump affluence as the primary goal of 'pro-family' development policy.

\section{Explaining facts with morals: ends-means issues}

Just as feminists struggled with their population-minded allies, 'pro-family' organisations are likely to run into problems as they pursue fertility under the name of staving off a 'demographic winter.' Feminists who sought to remedy human rights issues that did not fit with the macro-level agenda of their allies, such as treating fistulae and infertility in the developing world, found funding hard to come by. In the same way, it seems likely that if 'pro-family' organisations pursue the goal of higher fertility levels they may well succeed, but higher birth rates will not be delivered solely by 'natural families.' Similarly, huge families of atheists, socialists or liberals are unlikely to bring about the 'demographic springtime' desired by leaders of the 'pro-family' movement.

'Pro-family' emphasis on fertility, though it struggles to retain a positivist framework, consistently leads to advocacy for the containment of sexuality within

\footnotetext{
${ }^{113}$ See Weyrich, P. M. (2005) 'The Next Conservatism: The Next Conservative Economics,' Concerned Women for America, September 7, 2005. Available at http://www.cwfa.org/articles/8904/CWA/misc/index.htm [last accessed 11/08/09].
} 
marriage. This is despite the acknowledgement that out-of-wedlock births do significantly alleviate the 'birth dearth' in the industrialised world. In this way, the message of 'demographic winter' is constantly blurred: 'pro-family' environmentalist arguments about carbon footprints 'prove' that divorce is bad for the environment, but does this really say anything about fertility? It seems more likely that 'demographic winter' is a kind of umbrella phrase under which any regression analysis that associates the 'natural family' with a positive social outcome can be promoted.

Ultimately, arguments that utilise demographic and economic statistics are really about fighting normative trends to which 'pro-family' organisations morally object. As feminists and others before them have found, demographic facts cannot be made to support absolute moral positions. What will 'pro-family' groups do with high fertility that is not a result of maritally contained sex?

\section{'Pro-family' environmentalism?}

Sympathetic to those at the height of the 'population boom' who felt that it was not responsible to have a large family, some recent 'pro-family' discourse acknowledges that there is indeed a limit to the population that the Earth can sustain. This marks a shift for a movement that on the whole remains wary of environmentalism. In arguing that countries with lower birth-rates are the world's largest polluters, 'pro-family' organisations are starting to adopt a stance that brings stewardship of the environment into the 'pro-family' framework. In adding up 'carbon footprints,' 'pro-family' groups give some measure of credence to this form of environmentalism.

As has been shown in previous chapters, however, the 'pro-family' movement is suspicious, and even in some cases nauseated by environmentalist attitudes. Environmentalism is still seen as a coercive means of extending the reach of governments and international institutions in many 'pro-family' texts. Moreover, it is decidedly contaminated by association with the Left. Nevertheless, this fledgling 'pro-family environmentalism may be another way in which the 'pro-family' movement is able to 'integrate new ideas' into its agenda (as Butler puts it). But so far, this new concern with the environment is just another part of the 'pro-family' 
toolkit; that its use works in spite of the general flow of 'pro-family' politics as a whole may not be particularly important.

If the 'faithless' die out - so what?

'Pro-family' activists are enormously confident that 'people of faith' will survive 'demographic winter.' Moreover, 'real demographers,' as 'pro-family' activists put it, have always known what is going on, and have disagreed with "population controllers' and fought against their efforts to make people have fewer children. ${ }^{114}$ Given that 'pro-family' groups are hopeful about the potential of people of faith to inherit the Earth, how do they justify this warning - ostensibly directed to a secular audience - that a 'demographic winter' is looming? Why not keep quiet about it?

'Demographic winter' is likely to be seen by 'pro-family' activists as a means of entering new political arenas, declaring a commonsense solution to a problem that other political actors are unwilling to identify. Targeting Europe makes sense here, because its low birth-rate and high levels of immigration mean that the 'problem' is broadly acknowledged. Europe, once considered a lost cause in 'pro-family' circles, is now the recipient of 'pro-family' attempts to save it from extinction. Yet this rescue mission is bound to be a tricky one. Entering the immigration debate leaves 'pro-family' organisations open to accusations of racism, and the inherent nationalism implied in 'pro-family' solutions to 'demographic winter' may not be in harmony with other aspects of the movement's global activism. Balancing (at least rhetorical) concern for the people of the developing world whilst exploiting the racist fears of the West will be a difficult task for the 'pro-family' movement.

If people of faith are going to inherit the Earth, broadcasting the message of 'demographic winter' in a secular manner might have the effect of preventing or reducing this inheritance. One answer to this is that 'demographic winter' may be an outlet for the evangelical inclinations of the 'pro-family' movement. If the population of the world is threatened, Christians have a role to play in proselytising the non-religious (and childless) people of the world. In this case, they are called to spread the gospel of the 'natural family.' The secularism of the medium in this case

\footnotetext{
${ }^{114}$ See David Popenoe and Phillip Longman interviewed in Demographic Winter: the Decline of the Human Family (2008) SRB Documentary, LLC, Acuity Productions [DVD].
} 
just reflects the efforts of its proponents to reach as many people as they possibly can. Another possibility is that the 'pro-family' movement has become so deeply involved in changing social norms that so long as people's behaviour conforms to the 'pro-family' ideal, their religious status is of secondary importance.

In this way, 'demographic winter' raises a broader question about the role of religion in 'pro-family' activism. Can 'pro-family' activists continue to diminish the importance of religion into a mere 'variable' that hinders or helps family life? Or will 'pro-family' activists feel the need to acknowledge their religion as being of paramount importance - just as human rights are to feminist NGOs - pervading all aspects of life regardless of its effects on macroeconomic and demographic outcomes? This question may be of interest to future observers of the 'pro-family' movement.

\section{Conclusion}

'Pro-family' discourse around fertility is changing. Where they had previously focused much of their international advocacy against 'population controllers,' 'profamily' organisations now see fertility decline as an issue that is connected to changes inherent in the process of secular modernisation. In other words, where fertility decline was once considered a result of malevolent forces external to societies, 'pro-family' groups are now more likely to frame their arguments in terms of an impending 'demographic winter,' the result of 'anti-family' cultural changes which influence people's decisions to have smaller families, or to forgo family life altogether.

'Pro-family' interest in fertility, which was previously focussed on the people of the global South, now also encompasses 'pro-family' concerns about the West. The new focus on Europe may mark a significant shift for a movement which initially globalized - at least rhetorically - in defence of the Southern poor. This indicates that the movement may be seeking to move beyond development politics and into the broader realm of international and domestic social and economic policy-making.

'Pro-family' groups now highlight a number of different reasons for declining fertility, many of which revolve around what their leaders see as the 'anti-family' 
economic, social and cultural environments of developed countries. Other 'profamily' intellectuals link declining fertility directly to the removal of religion from public life in developed countries. 'Population controllers' are still at large in the view of many 'pro-family' activists, but they are no longer the main focus of 'profamily' actors interested in population issues.

This changing emphasis emerges in a number of different ways. For example, where 'pro-family' organisations have tended to oppose the supply of contraceptives and condoms to the developing world, they are increasingly placing themselves in opposition to what they see as the cultural messages associated with industrial capitalism. These messages, they suggest, are loaded with individualism, and bring selfishness and ultimately, unhappiness to the countries they 'infect.' Another example of this changing emphasis is in 'pro-family' organisations' increasing recognition that it is now normal to want to limit the size of one's family, rather than making the claim that it is coercive 'population controllers' and governments that are responsible for declining fertility. 'Pro-family' efforts are now focused on changing people's attitudes about larger families, and recasting old enemies - abortion, contraception, homosexuality, feminism and socialism - not just as problems in themselves, but as contributors to 'demographic winter.'

Towards the end of their chapter on population policy and Christian Right activism, Buss and Herman observe that debates about population have led the Christian Right to adopt a 'pro-development' agenda, in the sense that they now compete with feminists in their claim to speak on behalf of women. In doing so, 'pro-family' organisations (to some extent) forgo their suspicion of international development. Thus Buss and Herman pose the following question: can the new 'developmentfriendly' approach of 'pro-family' organisations be reconciled with the Christian Right's 'long-standing and often vehement objection to international measures as amounting to governmental interference in the free operation of the market and undermining US independence?' ${ }^{115}$ They suggest that the answer is probably no.

${ }^{115}$ Buss and Herman, op. cit., p. 78 
My findings suggest that the 'pro-family' movement may have found a way to get around this conflict. In defending the rights of people in developing countries to have large 'strong' families, free from the interference of secular development models, these organisations claim to speak on behalf of the people of the developing world even as they suggest that poverty alleviation is not the answer (as their models show, the accumulation of wealth is in opposition to the accumulation of children). Advocacy for increasing family size in the West can be framed as reducing the future burden on the families of the South, as their men will no longer be encouraged to migrate for work at better wages in rich foreign lands. Families in the South are glorified as young, strong and fertile, and juxtaposed with those in rich countries which are small and old.

Time and again we see the 'pro-family' movement adapt to new political requirements and use new tools to advance their cause. Demography, once an instrument of environmentalists and progressives, is now wielded with fierce determination by 'pro-family' advocates of the 'natural family.' Racism, a charge once used to sideline the predominantly white Christian Right, is now being turned back on progressives. Progressives are culpable, say 'pro-family' groups, because in their support for population control and abortion they have coerced and targeted disadvantaged ethnic groups.

Environmentalism is another example of this adaptation. Buss and Herman suggest that phrases such as 'sustainable development' and 'caring for the Earth' are seen by 'pro-family' groups as globalist ambitions; a part of 'the UN's hidden agenda for ideological control. ${ }^{116}$ Though their analysis may be true of earlier 'pro-family' discourse (and especially that of the domestic Christian Right), this chapter has shown that though the organisations remain sceptical of environmentalism, a budding 'pro-family' version in support of the 'natural family' is emerging.

In all of this change, then, what can be said about the global future of the "profamily' movement? Can the 'pro-family' movement continue to garner support from the global South as it challenges some of the more broadly accepted ideas

${ }^{116}$ Ibid. p. 21. 
about development? If it is successful in doing so, how will this affect the movement's domestic base? How much accommodation to new ideas can 'profamily' organisations manage before the cracks start to show? These are the questions I consider in the conclusion to this thesis. 


\section{Conclusion}

Though they no longer enjoy the patronage of a president sympathetic to their views, the global activism of 'pro-family' organisations shows no signs of abating. A sixth World Congress of Families is scheduled for 2011, and new conservative, 'pro-life' and 'pro-family' organisations continue to register for NGO accreditation at the UN. ${ }^{1}$ This may reflect an overall burgeoning in civil society participation at the UN in general, but it also shows an increasing interest on the part of US 'profamily' organisations in political participation beyond their homeland.

This participation is sustained by the earnest commitment of 'pro-family' organisations to prevent progressive norms about sexuality and reproduction from being further established as dominant models, both in the development arena and beyond it. In their global endeavours to save the unborn and maintain the social value of chastity, modesty and 'traditional' understandings of gender, 'pro-family' groups have created a global network of likeminded activists, a ready source of inspiration to maintain the movement as it struggles to pursue its agenda. Over time, this agenda has changed to suit the political milieu, growing in sophistication, funding and intellectual depth. This thesis has attempted to capture the ideological views of the 'pro-family' movement, and show some of the important ways that their discourse has shifted as they have established and continue to maintain a global presence.

In terms of their views on globalization and how the world is changing because of the phenomenon, 'pro-family' groups now tend not to depict 'globalists' and a 'new world order' as the forces behind global change. They still oppose globalization as a homogenising force, but for the reason that in its present form it is secular, individualistic and relativising, rather than because they perceive that a set of powerful people are orchestrating global change for the purpose of achieving totalitarian outcomes. Totalitarian outcomes may occur, in this altered 'pro-family' view, but this will be a result of unrestrained liberal capitalism racing to forget

\footnotetext{
${ }^{1}$ Recently UN-accredited NGOs include the American Conservative Union (2007), the Congregation of Our Lady of Mount Carmel (2009), Feminists For Life (2005) and the Hudson Institute (2008). For more information see http://esango.un.org/civilsociety/login.do [last accessed 04/09/2008].
} 
religion, 'traditional morality,' and the importance of family life. The role of 'profamily' organisations in this view is thus not just to represent these things in the global public realm; it is also to preserve them in human memory. In this way, we can see that the threat of annihilation is still present in the 'pro-family' political world, but the agents of chaos are beginning to be depicted as aspects of modern culture itself, rather than in the form of would-be evildoers at large in the world. Yet this may not be such a large shift, as the elites targeted by 'pro-family' organisations earlier in their activism were the focus of 'pro-family' ire precisely because they espoused and encouraged liberal and individualistic ideas about how the social world should be organised.

However it is framed, anti-individualism is most certainly emerging as a key component of 'pro-family' discourse (as evident in the theme of the Amsterdam WCF conference: 'the family: more than the sum of the parts'). With this new perspective, 'pro-family' activists are both better-off and worse off. They are better equipped to bring about the outcomes they desire, because they are tackling the root causes of the political changes they do not like, and they will find many likeminded people from beyond the limits of US Christian conservatism to join their cause. But in staking their claims against the individualistic culture of modernity itself, 'pro-family' groups will be obliged to address the new tensions and contradictions within their worldview.

Despite the enormous task they have set themselves - a worldwide 'pro-family' reversal of modern values - 'pro-family activists seem content to work towards long-term change. In their tireless organising and prolific publishing, Carlson, Crouse, Dobson, Euteneuer and their allies often give the impression that they are already riding a wave of 'pro-family' euphoria that cannot help but spread across the globe. Though they scramble to oppose globalization, 'pro-family' groups continue to embrace certain universal principles and strengthen their global network. 'Pro-family' organisations also enthusiastically participate in the global propagation of norms and ideas, even while they oppose the interference of their opponent's ideas as violating the sovereignty of other nations. In their actions and proposed policy positions, 'pro-family' groups accept, take advantage of, and can even be said to advance a form of globalization. 
In 1994, Peter Beyer made the following prediction:

'... if particular cultures are to survive in altered form in the modern global context, the religious traditions associated with them will also survive, but not without themselves facing the serious challenge of the relativised context. Given that religions deal with absolutes, this adjustment should result in significant crises within those traditions. ${ }^{2}$

Beyer's insistence on the incompatibility between the relativism wrought by globalization and the universalism of religion guides observers of emerging global religions to seek out this struggle in the discourse of the religious movements they examine. My research suggests a new response or episode in the adjustment of religious communities to modernity and globalization. Many religious people have reacted to globalization in the same way, have found in its challenges more commonalities than differences with each other, and have paradoxically confirmed (at least in their own eyes) that their views are, after all, 'universal.'

Thus if globalization is a crisis for conservative religious groups, it has also been an opportunity. This global 'pro-family' network may be the result of many particular crises, in which different groups rise to face similar challenges to their way of life; as Butler suggests, rather than challenging it, globalization may have caused (and may in fact be strengthening) the 'pro-family' movement. In terms of the survival of certain religious traditions referred to by Beyer, we can see that a number of tenets historically associated with the 'pro-family' movement have indeed survived the process of globalization. The Christian Right suspicion of international institutions still remains, though altered, and fear of extinction has been smoothly transferred to the global context. Opposition to abortion, and to a lesser extent, homosexuality, still dominate the political agenda of these organisations.

Yet much has changed. The 'pro-family' view of the UN, an organisation cast for a time as the force majeure behind the impending enslavement of the world's people, now more often than not is spoken of with a kind of cautious familiarity in "profamily' parlance, reflecting a decade and a half of investment in the institution.

\footnotetext{
${ }^{2}$ Beyer, P. (1994) Religion and Globalization (London: Sage), p. 9.
} 
Though they are still largely dissatisfied with most of its outcomes, 'pro-family' activists now see themselves as belonging to the democratic process that goes on at the UN. Their integration may, in time, be considered an enormous achievement of the UN civil society process.

Inclusion, though, has its costs for the 'pro-family' movement. Buss and Herman ask whether 'pro-family' groups actually want to pull the UN back from its slide into 'anti-family chaos,' given that Christian Right activism there goes some way to legitimising an organisation that is seen as a key threat to the "natural family. ${ }^{3}$ The research in this thesis suggests that if 'pro-family' groups were ambivalent about their role at the $\mathrm{UN}$, their certainty about their presence there is increasing. Carlson's steady repetition of Article 16, Ruse's desire to form a permanent 'profamily' bloc at the General Assembly, and Crouse's dedication to 'fixing' the UN show a movement that is now dedicated to rescuing this organisation with an injection of 'pro-family' values and zeal. Thus the UN is seldom considered an evil entity in recent 'pro-family' pronouncements; it is seen as a legitimate institution, although with a number of problems, which is worth saving.

As expected, association with the UN has had an important effect on the discourse of 'pro-family' organisations. HLI stands out among the organisations under scrutiny in this thesis not only because of the peculiar take it has on the world, but also because of the venom in the language it uses. HLI does not have the same reason to modify its language or behaviour in the way that its 'pro-family' allies do, because it has no UN accreditation to lose. Moreover, it is likely that by speaking in the way it does, HLI has developed a niche audience of supporters and donors who appreciate the organisation's combative vernacular.

In addition, though they do not say so outright, it is likely that the UN now also functions as a bastion for the defence of nationhood in the 'pro-family' world view. This is somewhat ironic, because it was not long ago that the UN was considered to be a major 'globalist' threat to the very idea of nationhood. Though the organisations condemn what they see as attempts by the UN to violate national

\footnotetext{
${ }^{3}$ Buss, D. and D. Herman (2003) Globalizing Family Values: the Christian Right in International Politics, (Minneapolis: University of Minnesota Press), p. 79.
} 
sovereignty, they surely prefer it to the prospect of a globalizing world without the UN. For without the UN to represent, justify and reify nations, globalization as understood by 'pro-family' organisations would probably be even more socially destabilizing than it already is. Torn between enduring social chaos or supporting a forum they once depicted as the forefront of a new 'anti-family' order, 'pro-family' groups, it would seem, have decided to err on the side of order and maintain their presence at the UN.

Similarly altered is the 'pro-family' view of feminism. Both feminism and the UN are now seen as noble causes that have been hijacked by totalitarians and 'radicals,' and both are seen as potentially beneficial forces in the 'pro-family' battle for the future. As noted by a number of different scholars, 'pro-family' leaders no longer oppose all feminism as immoral, rather they oppose a certain type of feminism that they see as rampant in the development arena. 'Radical' feminists, once seen as the smokescreen for totalitarian elements in the UN, are now frequently depicted as part of a hijacked tradition, a righteous idea infiltrated and corrupted by liberal and secular forces. Feminism is still seen as dangerous, but this is because of its association with the set of ideas that make modern culture selfish and individualistic, not because feminists are attempting to bring about a 'new world order.'

Certainly the fight to represent the true needs of poor women is still being waged by 'pro-family' forces and their progressive counterparts, but 'pro-family' organisations increasingly depict the efforts of their feminist opponents as a feature of secularism and liberalism. In this framework, if it were not misinformed by these ideologies, the feminist impulse would in fact be 'pro-family,' rather than a distinct fifth column. Feminism, in recent 'pro-family' discourse, occupies an odd position. Though they are not really given the full share of blame or credit for the 'antifamily' aspects of modern society, the issues raised by 'pro-family' activists are still all about feminist issues: sexual and reproductive health, homosexuality, and women's rights and empowerment. 'Pro-family' leaders seek to sideline feminists, even as they directly address and argue against feminist ideas. 
In this way, 'pro-family' groups do not address feminism as a cause of 'demographic winter' as such, rather they highlight social changes associated with feminism - the sexual revolution, and access to divorce and contraception - as reasons for declining fertility. 'Demographic winter' is the chief example of the new modus operandi of the 'pro-family' movement: a collection of regression analyses that finally 'prove' that the 'natural family' is the way to achieve better social outcomes. This approach has potential in its appeal to policymakers, but also compromises the movement. One major issue is that family life and religion become means to socially prescribed ends, an idea which is bound to raise concern for a movement that is suspicious of central planning and ideological control, be it through governments or the UN.

Another issue with the recent efforts of 'pro-family' activists to use social science research is that they run the risk of blurring the agenda of the movement. As "profamily' experts on 'demographic winter' acknowledge, retaining higher birth rates may mean encouraging everyone to have more children, wed or unwed. Just as feminists discovered decades ago, targeting fertility does not always bring about desired outcomes. Moreover, if the assumption that large families make honest, generous and well-socialised people (as discussed in the previous chapter) is broadly accepted in the movement, the emphasis on the containment of sex within marriage may be compromised. The social role of marriage is the lynchpin of most 'pro-family' arguments that purport to 'defend' the married state.

'Demographic winter' discourse justifies and necessitates the turning of 'profamily' activists attention to Europe, a major shift for a movement that had previously relied on taking the moral high ground in defence of poor families in the South to legitimise its global activism. Though 'pro-family' groups do still articulate their activities as defending the victims of Western governments and institutions (especially women), their interest in Europe marks an attempt to move their politics beyond the development arena, as noted in chapter six. It seems likely that 'pro-family' activists will continue to exploit Europe's demographic 'crisis' for as long as they can, because the continent is so politically threatening to the "profamily' movement. By denying its Christian heritage, secular Europe also calls into question the core religiosity of the US. Also, as Butler suggests, as a 'super- 
government,' the EU threatens to disseminate its 'nihilist values' to the rest of the world. ${ }^{4}$ Similarly, the new 'pro-family' approaches to the UN and feminism also show the extent to which political concerns are guiding this discourse. The movement could no more maintain its outright hostility to the UN than it could continue to frame development as a problem of paganism. Likewise, feminists will no longer be depicted as the smokescreen for a 'new world order' if their threat is diminished in the 'pro-family' political world. Though they may never again be seen by 'pro-family' activists as powerful agents of change, however, it is likely that feminists will always be a part of 'pro-family' discourse, ensconced as they are in the issues against which the movement rallies.

As in the past, 'pro-family' groups see themselves as trying to hold back dangerous new trends. In this way, they portray themselves as steering global norms 'back': back to the original intentions of the founders of the UN; 'back' to valuing the 'natural' morality of families in developing countries; 'back' to a time when culture and traditions were respected in the industrialised world. Though there is some evidence that they are increasingly aware of the new issues faced by families of the South - the absence of fathers in the developing world due to labour migration, for example - the movement is still a deeply nostalgic one. Yet for a global movement that seeks to inspire sweeping global 'pro-family' change, is this focus on arresting and reversing progress a good fit? Do they want to go forward to a 'demographic springtime' or back to a time before 'development' began to occur?

The changes highlighted in this thesis suggest that 'pro-family' involvement in development is more about bringing attention to the problems of the West than about advocating for meaningful change for people in the global South. In this sense, unless the 'pro-family' movement starts to address the glaring poverty, environmental decay and lack of human security faced by families in the South, it is in grave danger of being seen as pursuing a wholly self-serving endeavour.

Yet perhaps judging the 'pro-family' movement by such progressive criteria is to miss the point of its political activism. 'Pro-family' progress would like to see

\footnotetext{
${ }^{4}$ Butler, J. S. (2006) Born Again: The Christian Right Globalized (London: Pluto Press), p. 144.
} 
poverty alleviated and democratic protections enjoyed across the globe, but without what they see as the institutionalised selfishness which has been a part of modern capitalist development in the West. The 'pro-family' blueprint for development would temper market fundamentalism with religion and 'family values,' and if Dobson and Carlson's views were to prevail, with the institutionalisation of a tax system that favoured large, single-income 'natural' families.

In working towards this ideal, 'pro-family' groups are likely to continue to appeal to religion as the cure for 'anti-family' political change, and large families as the antidote for individualism. The nexus of orthodox religion and idealised family life will remain the core ideals for the movement, with abortion and homosexuality framed as both the wilful rejection of these principles and as forces that threaten to damage people already following the 'pro-family' path. The change that the research in this thesis suggests is that 'pro-family' appeals will be made against modern ideas and culture rather than entities and people. The 'friend-foe' way of thinking endures, but in an altered form. Expect to see more 'pro-family' arguments couched in regression analyses: crime, health indices, wealth, and other indicators of social stability will all be marshalled to support 'pro-family' development policy. Cogent arguments explaining these correlations in terms of materialism, selfgratification and secular values - and their 'opposites,' self-sacrifice, discipline and Christian principles - will be advanced as justifications and acclamations for the influence of the 'pro-family' movement in policymaking.

\section{$\underline{\text { Overall observations }}$}

If Buss and Herman are correct in their suggestion that the Christian Right have globalized in order to mainstream their political movement, then this research suggests that they have been largely successful in that endeavour. 'Pro-family' discourse has changed significantly since these organisations became active in the international arena. Concern with globalism and a rising 'new world order' in 'profamily' discourse' has transformed into more social science based criticism about the effects of modernity on family life. The movement away from evil entities in 'pro-family' discourse has allowed the movement to be far more appealing to those who do not share its legacy of conspiracy theories and suspicion. The incorporation of empirical material to support their positions is an also an important way in which 
'pro-family' groups are demanding to be taken seriously by people all over the political spectrum.

As they get more involved in international politics, 'pro-family' groups are getting more specific about the aspects of development of which they disapprove. Since the 1990s, 'pro-family' groups have incorporated aspects of feminism into their political ideology, have gone from opposing the UN as an entity to seeing it as a forum which they can use to bring about meaningful change. This is also an aspect of mainstreaming, and is likely to happen more, rather than less, as the groups tone down their righteous anger in order to be taken seriously by their political peers.

Yet the way the 'pro-family' movement is changing as a result of its global endeavours problematises the very idea of 'mainstream' politics. Under the tutelage of Christian Right academics and think-tank researchers, the 'pro-family' view of the world can be considered both more and less mainstream. Being more conventional in its appeal to a wider set of people in that its politics (now framed in terms of protecting the family from the excesses of modernity rather than from unseen but nefarious global nemeses) means that the movement can no longer be written off as a far-right religious cult with a conspirational bent. On the other hand, the 'pro-family' movement is remains critical of some widely held ideas and norms. In the light of the $21^{\text {st }}$ century, Dobson's position on 'wilful' childlessness as moral rebellion, and Carlson's opposition to economic materialism are relatively revolutionary ideas. This is acknowledged by some of the more thoughtful 'profamily' intellectuals; as Carlson laments, the human heart is no longer 'pro-family.' Moreover, 'pro-family' organisations now see a role for themselves in a far wider range of political roles: in the attempt to 'mainstream' the 'pro-family' agenda into areas beyond its original scope, such as health, immigration, economics, and increasingly, academia, 'pro-family' activists are showing that they seek to totally transform the way people think about their world. Again, Carlson recognises and embraces this revolutionary sentiment in his suggestion that the world needs a 'counter-revolution' in values.

Ten years ago, few would have guessed that the spark for this 'pro-family' counterrevolution might be sought in 'secular, childless' Europe. Yet the focus on this 
continent has been intensifying for some time, and has stimulated sufficient European interest in the 'pro-family' cause to justify continued activism there. The focus on Europe is also likely to contribute to the increased secularisation of "profamily' arguments, as the groups change their discourse to suit a European audience. In some ways, this complicates Butler, Jenkins and Brouwer, Gifford and Rose's forecast that the conservative Christian centre of gravity is moving South. If these authors are correct in this prediction, the unwillingness of 'pro-family' organisations to relinquish Europe (and the secular, industrialised world in general) splits the 'pro-family' movement from this southwards trend. That 'pro-family' organisations have found allies in European countries and acted promptly to strengthen these alliances to 'save' Europe speaks to the wider literature on the Christian Right: it shows both the importance of the emergence of 'pro-family' statisticians and demographers (providers of what Buss and Herman refer to as 'expert discourse') and the significance of international alliance building - friends, not just foes - in directing the activism of this movement. Future examinations of the global activism of Christian Right 'pro-family' organisations would do well to further examine this finding.

Buss and Herman, among others, have suggested that the Christian Right view the world outside the US as a hostile place. My research shows that while this has been a characterisation of 'pro-family' thought in the not too distant past, it is no longer the case. 'Pro-family' groups now perceive that their future political role lies beyond the US, a realm they now depict as relatively receptive to their message. As an explanation for this change, I suggest that the organisations' movement into the global realm - their policy achievements and beneficial alliances - has fundamentally changed their view of the world beyond the US.

In The Battle for God, Karen Armstrong writes that American Protestants in the 1970s

'felt alienated from modern secular culture but their leaders at least enjoyed prosperity and success. This would later prove to be one of their problems. Despite 
their conviction that they were outsiders, Protestant fundamentalists were very much at home in America. ${ }^{5}$

This, I suggest, has largely been true of the 'pro-family' experience of the global realm as well. Though they relished their hated status at the UN and took pleasure in portraying themselves as a small but courageous force fighting the onslaught of feminists, globalists and the like, 'pro-family' leaders can no longer claim to be fighting the good fight alone in a wholly hostile environment. This, I suggest, is because they have taken advantage of globalization and enjoyed considerable success in the global realm, especially compared to their achievements domestically. Moreover, 'pro-family' groups now claim to represent the 'natural families' of the world, defending what they see as an innocent majority from the corrupting norms and practices of modern secular culture.

Part of what the families of the developing world need to be protected from is capitalism itself, although this is far from established in 'pro-family' circles. Distrustful of corporations and increasingly scornful of the drive to consume, a number of 'pro-family' leaders now stress the importance of 'fixing' capitalism in order to make it encourage marriage and family formation, and discourage avarice and egotism. In addition, affluence has been questioned as an objective of development and public policy, given its highly negative impact on fertility.

In this sense, Butler and Petchesky's concern, that the culture wars distract the public's attention from an economic agenda that is harmful to the vast majority of the world's people, may in time become apparent to 'pro-family' organisations. ${ }^{6}$ Many in the 'pro-family' movement are aware of the uglier aspects of unrestrained global capitalism. Joint activism with left wing opponents of global capitalism is not without precedent, as witnessed in Seattle in 1999. However, as it stands, 'profamily' organisations still impede the transfer of funds to the developed world, attaching so much more attention to condoms, contraception and homosexuality than suffering and poverty that it seems highly unlikely that they will more closely ally their agenda with their ideological opponents in the near future. Moreover,

\footnotetext{
${ }^{5}$ Armstrong, K. (2000) The Battle for God: Fundamentalism in Judaism, Christianity and Islam, (New York: Knopf), p. 309.

${ }^{6}$ Butler, op. cit., p. 11.
} 
though they may agree with progressives that there is a problem with capitalism, it is difficult to think of any kind of economic solutions on which both sides might actually support. Though some 'pro-family' leaders are growing increasingly vocal in their opposition to unbridled capitalism in the name of protecting 'the family,' this remains a very tentative adjustment in 'pro-family' discourse.

It is unlikely that any new and critical consideration of capitalism would have been raised and sustained in 'pro-family' discourse without the intellectual impact of Allan Carlson on the movement. Carlson, the force behind the WCF, has arguably been the key figure bringing about the changes in the 'pro-family' movement that this thesis has documented, especially in its shift away from suspicion and vehement antipathy. Carlson is the chief instigator of the term 'natural family,' with which he has largely shaped the agenda of the 'pro-family' movement. $\mathrm{He}$ is the coauthor of the Natural Family Manifesto, in which he seeks to guide 'pro-family' activism to some degree.

In his efforts, Carlson has broadened the appeal of the international Christian Right beyond a narrowly reactive politics opposing abortion and population control, to include a number of different issues faced by people in many different parts of the world. Though the 'pro-family' movement is still a largely reactionary one, Carlson's emphasis on the 'natural family' has been crucial to the movement towards criticism of norms and ideas that question 'traditional morality' and endanger the kinds of families he seeks to protect.

This discursive trend away from agents of evil goes some way to confirming one of Beyer's key ideas in his understanding of how religions must change as they globalize:

'the effort on the part of many people in the world nevertheless to preserve, stabilize, and (re)create particular identities ... constantly runs counter to this tendency of the global system to relativise them. The resulting conflict, in this case, is then not so much against rival cultures and identities, although people may formulate it as such, as against the corrosiveness of the system itself. ${ }^{7}$

\footnotetext{
${ }^{7}$ Beyer, op. cit., p. 2. Emphasis added.
} 
Under Carlson's leadership, the 'pro-family' movement is indeed beginning to comprehend that it is the absence of their religious principles from the global realm - rather than 'radical' feminists, liberals or globalists - which is behind the changes they so desperately seek to reverse. Though 'pro-family' groups have laid the blame for devaluing families and motherhood on their progressive opponents, their real complaint is that social norms have become so distorted that 'natural families' robust entities that have existed for millennia - must now be defended at all.

In this context, 'anti-family' agents would not have made any progress without an ideological structure that allowed their ideas to flourish and take hold as global norms. Globalization, in its current form, is providing that structure. Some 'profamily' leaders are beginning to acknowledge this. To revise Steve Bruce's words, in the new 'pro-family' discourse, bad things happen not so much because bad people want them to happen, but because bad ideas are so appealing and corrupting, and there is no global moral system to arrest their advance.

Buss and Herman's suggestion that millennialism is important in the makeup of Christian Right ideology has been borne out to some degree in this research. Though the emphasis on globalists has changed, there is evidence that some "profamily' groups still hold on to the idea that powerful and evil forces remain at large in the global realm. That they are now ideological rather than demonic organisations and people may not be a particularly important shift. Millennialism does persist as an aspect of the way the 'pro-family' movement looks to the future. Discourse around Demographic Winter is a case in point; the documentary is a curious blend of statistics set to an apocalyptic narrative: the millennium is coming, and here are some measurements to estimate when it might occur. A sophisticated 'rapture index,' if you will. Proponents of 'demographic winter' allude to a broad ranging plan to decimate the world's population, concocted by a set of global elites. In addition, the presence of a number of Christians - or in Demographic Winter terms 'real demographers' - who 'see what is really happening' and attempt to expose it to the public, is (consciously or otherwise) lifted out of the apocalyptic narratives of Christian Right prophetic literature and given a statistical gloss. 
Another way of framing this 'pro-family' view of the future is that it may not be millennialism that is driving 'pro-family' activists, so much as fear of annihilation. Karen Armstrong warns her readers not to underestimate the impact of dread and anxiety in motivating religious groups to defend their way of life against secular humanism. 'The desire to define doctrines, erect barriers, establish borders,' she suggests, are 'rooted in fear. ${ }^{8}$ In this context, 'demographic winter' is a plea to maintain the 'pro-family' way of life against the onslaught of secular modernity, which has evicted Christianity and family values from Europe and much of the industrialised world, and threatens to do the same everywhere else.

Hence it remains difficult to measure how important second coming beliefs are in the 'pro-family' view of the world. They are a part of the discourse, but they are conspicuously absent from the surface. Given the emphasis that this thesis has placed on the language of 'pro-family' representations of the world, perhaps greater sensitivity to 'pro-family' narratives 'between the lines' might have uncovered more underlying apocalyptic sentiments. Yet the absence of clear apocalyptic discourse may reflect the growing successes that the 'pro-family' movement has enjoyed under the Bush Administration: as their perceptions of their strength and potential have increased, so their millennial narratives have faded into the background. Should these groups face a major setback, we may once again see unconcealed references to end times on the rise.

The relationship between global 'pro-family' activists and the grassroots Christian Right movement remains an interesting question. My focus on elites as leaders of the movement does not allow me to assess what effect the changes in the global 'pro-family' movement have had, if any, on their domestic base. These organisations may have significant autonomy, but they are not 'free-floating' entities. Thus the relationship between the globally active 'pro-family' movement and the Christian Right as a whole is an area in which future researchers can uncover interesting shifts and important tensions.

${ }^{8}$ Armstrong, op. cit., pp. 368-9. 
Though the internet has been the source of my 'pro-family' texts, how much the internet is having an impact on the political evolution of 'pro-family' groups remains unknown. In solely focussing on materials published through the internet, it is possible that this research has overlooked some vital aspects of 'pro-family' activism. My analysis has not sought to explore the ways in which the internet itself is impacting on the way that social movements define and present themselves. Other researchers might consider how the medium itself moderates or intensifies 'pro-family' discourse, and the way in which it affects efforts to create a global 'pro-family' network. ${ }^{9}$

What has been undertaken in this thesis is a detailed analysis of 'pro-family' texts from 1997 to 2008. I have extended Buss and Herman's 2003 examination of the ideological underpinnings of 'pro-family' activism, confirming some of their findings and demurring on others. I have shown how the discourse of this movement has changed in the relatively short period covered in my timeframe. I have analysed an example of 'pro-family' 'expert discourse' in my chapter on 'demographic winter' and shown the way that it conforms with the general 'profamily' trend identified in my other research chapters, that 'pro-family' ideology is moving away from suspicion of powerful elites in the global realm and towards a full-scale condemnation of the values they see as inherent in the culture of secular modernity. The tensions involved in taking the movement in this direction have been analysed in each research chapter. This kind of research could be usefully applied to other kinds of social movements, for example, the left-wing antiglobalization movement.

Further research must examine how the global 'pro-family' network fares in the post-Bush context; in this endeavour, the ideas produced at 'Amsterdam 2009' would make an excellent starting point. Keck and Sikkink's boomerang theory might prove useful in analysing whether 'pro-family' organisations are keen to maintain their international role in order to bring pressure to bear on the Obama Administration. Given that there is little evidence of a slowdown in the global activism of the movement, the increasingly favourable 'pro-family' view of the

\footnotetext{
${ }^{9}$ But see Butler, J. S. (2006) Born Again: The Christian Right Globalised, Pluto Press, p. 160.
} 
political world outside the US makes for an interesting dynamic for observers of Christian Right politics in general. Another question for future observers of this movement is to consider how globally active 'pro-family' women combine their new brand of feminism with their global activism: how does the religious, powerful, 'pro-life' woman balance the expectations of conservatives from outside the US? Do they reject secular norms about equality in their global activism? Will 'profamily' women promote a form of women's empowerment with their conservative Islamic sisters?

Lastly, many gay people, liberals, and feminists agree with the 'pro-family' view that the 'me' culture inherent in modern consumption-driven economies, and its associated promiscuity and general obsession with sex, are indeed vulgar aspects of modern life. Research is required into the ways that 'pro-family' discourse deals with the adoption of positions with which its political opponents have some sympathy, even as its leaders lay the blame for the increase in this behaviour on the shoulders of these same opponents.

\section{Concluding remarks}

'Pro-family' discourse may be changing in all of the ways described above, but it still does not address the suffering of the people it now purports to be protecting from modern secular culture. 'Pro-family' organisations' still keenly oppose condoms, contraceptives and abortion, and their position that funding for these should be redirected towards the 'real needs' of women belies the fact that they still broadly oppose the redistribution of wealth from rich to poor. Even on their own terms, there is a disconnect between their stated concern for the 'real' needs of women in developing countries and their willingness to concretely address these needs. The reason for this disconnect is that the body of a needy third world woman remains a symbol for 'pro-family' organisations, highly invested with meaning, but not a real living body in need of sustenance and security. Despite their new prodevelopment approach, it is still the case that 'pro-family rhetoric and religious 
morality,' as Petchesky and Judd argued a decade ago, are 'synonymous with the eradication of social welfare programmes for the poor. ${ }^{10}$

As long as 'pro-family' organisations maintain their focus on opposing abortion and containing sex within heterosexual marriage, they are unlikely to make much of a difference in the lives of women in the global South, who are already largely living under those social norms. 'Pro-family' activism, in this sense, just detracts from efforts to improve the quality of health services in poor countries and ignores the plight of abused women and girls in deference to religion, 'tradition,' and the 'family.' Insofar as 'pro-family' organisations are developing a critical vision of the developed world, the reflection of this vision on the South now glorifies poverty and praises the absence of women's reproductive autonomy.

Nevertheless, distracting and destructive as their activism may be, 'pro-family' groups do highlight some important issues about the way we live. For conservative men and women who want to raise their children according to the norms of their parents and grandparents, globalization and the liberal ideas it spreads represent a multifaceted threat to their families and their way of life. New ideas about sexuality and reproduction do have a profound impact on families and communities, and not only on their size. Sexual and reproductive rights and the empowerment of women have complicated social consequences that must be acknowledged and managed.

Thus while it is tempting to hope that the changes in 'pro-family' discourse documented in this thesis - such as their opposition to consumerism and materialism, and their commitment to the world's families - might lead to genuine practical compassion towards those suffering under poverty, this is very unlikely. 'Pro-family' anxieties will not be overcome by the simple assertion that the enjoyment of sexual and reproductive health is a human right, nor will it be assuaged by measurements of improving human development indices or even by the prevention of disease, disability and death. Even in the face of such a depressing lack of development, the 'pro-family' movement will remain to remind whoever will listen that things are not as they should be in the West, either.

\footnotetext{
${ }^{10}$ Petchesky, R. and K. Judd (eds.) (1998) Negotiating Reproductive Rights: Women's Perspectives across Countries and Cultures (London: Zed books), p. 267.
} 


\section{Bibliography}

ABC News, 'Professor Criticised over Comments about Impending Pandemic,' Texas, Tuesday April 4, 2006, http://abclocal.go.com/ktrk/story?section=news/ state\& $\underline{\mathrm{id}=4051760}$ [last accessed 27/5/09].

Alrich, C. (2007) 'Abstinence Education Spending Requirement Hinders International Response to HIV/AIDS,' Guttmacher Policy Review, vol. 10, no. 2.

Andersen, K. (1988) 'Sources of pro-family belief: a cognitive approach,' Political Psychology, Vol. 9, No. 2, (June 1988).

Armstrong, K. (2007) On the Bible (New South Wales: Allen \& Unwin).

Armstrong, K. (2000) The Battle for God: Fundamentalism in Judaism, Christianity and Islam, (New York: Knopf).

Barnett, J. E. and C. S. Hurst (2003) 'Abstinence education for rural youth: an evaluation of the Life's Walk program,' The Journal of School Health, vol. 73, no. 7.

Beck, U., N. Sznaider and R. Winter (eds) (2003) Global America? The Cultural Consequences of Globalization, (Liverpool: Liverpool University Press).

Bergman, Y. (ed.) (2004) 'Breaking Through: A guide to sexual and reproductive health and rights,' The Swedish Association for Sexuality Education, Stockholm, available at http://www.rfsu.se/publications rfsu.asp [last accessed 15/07/09].

Beyer, P and L. Beaman (eds.) (2007) Religion, Globalization and Culture: International Studies in Religion and Society, vol. 6 (Leiden, Boston: Brill).

Beyer, P. (1994) Religion and Globalization (London: Sage).

Black, E. (2003) War Against the Weak: Eugenics and America's Campaign to Create a Master Race (New York, London: Four Walls Eight Windows).

Brouwer, S., P. Gifford and S. D. Rose (1996) Exporting the American Gospel: Global Christian Fundamentalism (Routledge: New York and London).

Bruce, S. (2008) Fundamentalism (2 $2^{\text {nd }}$ ed.) (Cambridge: Polity Press).

Burris, V. (2001) 'Small Business, Status Politics, and the Social Base of New Christian Right Activism,' Critical Sociology, vol. 27, no. 1.

Buss, D. and D. Herman (2003) Globalizing Family Values: the Christian Right in International Politics, (Minneapolis: University of Minnesota Press).

Butler, J. S. (2006) Born Again: The Christian Right Globalized (London: Pluto Press). 
Butler, J. S. (2002) A New Sheriff in Town: The Christian Right Nears Major Victory at the United Nations, Public Eye, available at http://www.publiceye.org/magazine/v16n2/PE Butler2.html [last accessed 29/12/08].

Catholic Family and Human Rights Institute publications:

Essig, A. M. (2007) 'World Bank: How it compromises Economic Development by Promoting a Population Control Agenda,' http://www.cfam.org/publications/id.332/pub_detail.asp, [last accessed 08/09/09].

Ruse, A. (2002) 'UNFPA Executive Director seeks additional funding for beleaguered agency,' Friday Fax, March 22, 2002, vol. 5, no. 13, http://www.cfam.org/publications/id.83/pub detail.asp [last accessed 24/08/09].

Ruse, A. (2001) 'Bush Negotiators Cheered for Conservative Statement at UN Child Summit,' Friday Fax, February 2, 2001, vol. 4, no. 7, http://www.cfam.org/publications/id.176/pub detail.asp [last accessed 20/08/09].

Ruse, A. (2000) 'Corporate Investments May Be New Conduit for Abortion in Developing World,' Friday Fax, January 7, 2000, vol. 3, no. 8. http://www.cfam.org/publications/id.123/pub detail.asp, [last accessed 11/08/09].

Ruse, A. (1999) 'UNICEF Believes State of War Exists Against World's Women and Children,' Friday Fax, vol. 3, no. 7, December 31, 1999, https://www.cfam.org/publications/id.122/pub_detail.asp [last accessed 20/08/09].

Ruse, A. (1999) 'Mainstream Media Increasingly Covers Emerging Depopulation Scare,' Friday Fax, vol. 2, no. 41, August 20, http://www.cfam.org/publications/id.104/pub_detail.asp [last accessed 28/08/09].

Ruse, A. (1999) 'Chairman Criticized/ Many Nations Reserve on Final Cairo+5 Document,' Friday Fax, vol. 2, no. 35, July 8/9, 1999, https://www.cfam.org/publications/id.98/pub_detail.asp [last accessed 20/08/09].

Ruse, A. (1999) 'Overreaching by US and EU Angers Developing World, Stalls Cairo+5,' Friday Fax, April 9, 1999, vol. 2, no. 23, http://www.cfam.org/publications/id.86/pub_detail.asp [last accessed 24/08/09].

Ruse, A. (1999) 'UN Double Standard Favors Western Nations Against Developing World,' Friday Fax, March 19, 1999, vol. 2, no. 21, http://www.cfam.org/publications/id.83/pub detail.asp [last accessed 24/08/09]. 
Ruse, A. (1998) 'UNICEF Uses American Media Giants to Spread Feminism to Developing World,' Friday Fax, October 2, 1998, vol. 1, no. 51. http://www.cfam.org/publications/id.60/pub detail.aspl [last accessed 11/08/09].

Ruse, A. (1998) 'New Session of the UN General Assembly Begins Work in New York City,' Friday Fax, vol. 1, no. 48, September 11, 1998, http://www.cfam.org/publications/id.57/pub detail.asp [last accessed 20/08/09].

Ruse, A. (1998) 'Population Action International Calls for More African Abortions,' August 28, vol. 1, no. 46. Available at http://www.cfam.org/publications/id.55/pub detail.asp [last accessed 14/08/09].

Singson, S. (2007) 'World Congress of Families Convenes in Poland,' Friday Fax, vol. 10, no. 21, May 10, 2007, http://www.cfam.org/publications/id.513/pub_detail.asp [last accessed 26/08/09]. Singson, S. (2006) 'Secretary-General Puts "Gender Equality” At Center Of UN Reform Proposal,' Friday Fax, vol. 9, no. 48, November 16, 2006, http://www.cfam.org/publications/id.488/pub_detail.asp [last accessed 20/08/09].

Singson, S. (2006) 'Senior UN Official Outlines Vision for New UN Women's Office,' Friday Fax, vol. 9, no. 47, November 9, 2006, http://www.cfam.org/publications/id.487/pub_detail.asp [last accessed 20/08/09]. Singson, S. (2006) 'Controversial "Rights” Being Pushed at Human Rights Council,' Friday Fax, vol. 9, no. 42, October 6, 2006, http://www.cfam.org/publications/id.481/pub detail.asp [last accessed 20/08/09]. Sylva, D. A. (2004) 'CFFC Seeks to Eliminate Pope's Pro-Life "Armada" from Europe,' Friday Fax, vol. 7, no. 3, January 9, 2004, http://www.cfam.org/publications/id.338/pub_detail.asp [last accessed 26/08/09].

Sylva, D. A. (2003) ‘The United Nations Children's Fund: Women or Children First?' International Organizations Research Group, White Paper, https://www.cfam.org/docLib/20080424 Number 3 UNICEF 2003.pdf [last accessed 20/08/09].

Sylva, D. A. (2002) 'The United Nations Population Fund: Assault on the World's Peoples,' International Organisations Research Group, White Paper Series Number Three, http://www.c-fam.org/publications/id.327/pub detail.asp [last accessed 20/08/09]. 
Yoshihara, S. (2006) 'Left and Right Agree, UN Compliance Committees

New Front Line in UN Abortion Debate,' Friday Fax, September 29, 2006, vol. 9, no. 41, http://www.c-fam.org/publications/id.480/pub detail.asp [last accessed 24/08/09].

(2006) 'Violence Against Women and Children Resolutions Still Outstanding at UN Third Committee,' Friday Fax, vol. 9, no. 49, November 23, 2006, http://www.c-fam.org/publications/id.489/pub_detail.asp [last accessed 17/08/09]. (2005) 'Conservative Document Endorsed by 700 NGOs Presented to UN Today,' Friday Fax, vol. 8, no. 38, September 9, 2005, http://www.cfam.org/publications/id.424/pub detail.asp [last accessed 17/08/09]. (2004) 'UNFPA Report Claims Reproductive Rights Still Key to Development,' Friday Fax, vol. 7, no. 39, September 17, 2004, https://www.cfam.org/publications/id.373/pub_detail.asp [last accessed 20/08/09]. (2004) 'Girding for UN Defeat, Cloning Advocates Seek to Move Decision to UNESCO,' Friday Fax, vol. 7, no. 33, August 6, 2004, http://www.cfam.org/publications/id.368/pub detail.asp [last accessed 20/08/09]. (2004) 'Mexico City Conference to Highlight Role of Family in Development,' Friday Fax, vol. 7, no. 7, February 6, 2004, http://www.cfam.org/publications/id.342/pub_detail.asp [last accessed 17/08/09]. (2003) 'C-Fam Releases Major Report on Radical Feminist Takeover of UNICEF,' Friday Fax, vol. 6, no. 34, August 15, 2003, https://www.cfam.org/publications/id.305/pub_detail.asp [last accessed 20/08/09]. (1999) 'First Prepcom for Copenhagen+5 Ends in Stalemate at UN Headquarters,' Friday Fax, vol. 2, no. 31, June 4, 1999, http://www.cfam.org/publications/id.94/pub_detail.asp [last accessed 17/08/09]. (n. d.) 'International Organizations Research Group,' http://www.cfam.org/publications/id.68/default.asp [08/09/09].

Clarke, G. and M. Jennings (eds.) (2008) Development, Civil Society and Faith Based Organisations: Bridging the Sacred and the Secular (London and New York: PalgraveMacMillan).

Cohen, R. and S. M. Rai (2004) Global Social Movements, (London: Continuum). Concerned Women for America publications: 
Colon, A. (2000) 'We need a new Women's Movement....Now!' 12 December, 2000 ,

http://www.cwfa.org/articledisplay.asp?id=1105\&department=CWA\&categoryid=f amily [31/03/08].

Crouse, J. S. (2007) 'UN Considers Adding Billion-Dollar Women's Agency,' 28 February, 2007, http://www.cwfa.org/articles/12424/BLI/reports/index.htm [last accessed 26/08/09].

Crouse, J. S. (2007) 'the United Nations' Abortion Dilemma,' 2 March, 2007, http://www.cwfa.org/articles/12441/BLI/reports/index.htm [last accessed 27/08/09].

Crouse, J. S. (2006) 'The Big G - Globalization: Demagoguery about "America's Economic Exploitation", August 16, 2006,

http://www.cwfa.org/articledisplay.asp?id=11328\&department=BLI\&categoryid=n ation [last accessed 12/08/09].

Crouse, J. S. (2006) 'Misguided Attempts to Eradicate Global Poverty: An analysis of the National Council of Churches Study Guide on the Millennium Development,' 15 August, 2006.

http://www.cwfa.org/articledisplay.asp?id=11307\&department=BLI\&categoryid=r eports [last accessed 11/08/09].

Crouse, J. S. (2005) 'Dowd Declares Feminism's Defeat: her bitterness is palpable,' 21 November, 2005, http://www.cwfa.org/articles/9503/BLI/commentary/index.htm [last accessed 27/08/09].

Crouse, J. S. (2005) ‘A Contest of Wills,' 1 March, 2005, http://www.cwfa.org/articledisplay.asp?id=7573\&department=BLI\&categoryid=na tion [last accessed 24/08/09].

Crouse, J. S. (2004) 'Two Gatherings: Which Agenda is Extreme?' 27 April, 2004, http://www.cwfa.org/articles/5726/BLI/dotcommentary/index.htm [last accessed 26/08/09].

Crouse, J. S. (2004) 'Feminism and the Family,' Remarks at the World Congress of Families III, Mexico City, March 29, 2004, http://www.cwfa.org/articles/5435/BLI/commentary/index.htm [last accessed 13/03/08]. 
Crouse, J. S. (2004) 'The Stalking Horse Named CEDAW,' 16 January, 2004, http://www.beverlylahayeinstitute.org/articledisplay.asp?id=5108\&department=BL I\& categoryid=reports [last accessed 20/08/09].

Crouse, J. S. (2003) 'Crouse delivers speech at Princeton: a conservative critique of feminism,' 8 October 2003, http://www.cwfa.org/articles/4693/BLI /media/index.htm [last accessed 24/08/09].

Crouse J. S. and B. LaHaye (2002) 'The Strength of a Godly Woman,' 2 February, 2002, available at

http://www.cwfa.org/articledisplay.asp?id=3154\&department=BLI\&categoryid=mi sc [last accessed 26/08/09].

Crouse, J. S. (2002) 'The United Nations' Ubiquitous and Destructive "Footprints",' 1 January 2002, http://www.cwfa.org/articles/1953/CWA/nation/index.htm [last accessed 28/08/09].

Crouse, J. S. (2002) 'UN Takes on Population and Free Markets,' Jan. 1, 2002, http://www.cwfa.org/articledisplay.asp?id=1951\&department=CWA\&categoryid= nation [last accessed 11/08/09].

Crouse, J. S. (2002) 'Stumbling Blocks on the road to Johannesburg,' January 1, 2002 ,

http://www.cwfa.org/articledisplay.asp?id=1955\&department=CWA\&categoryid= nation [last accessed 12/08/09].

Crouse, J. S. (2002) ‘UN/Hollywood Half-Truths', January 1, 2002, http://www.cwfa.org/articles/1954/CWA/nation/index.htm, [last accessed 11/08/09].

Crouse, J. S. and B. La Haye, (2001), 'A Counterfeit Strength,' Family Voice, September/October 2001, http://www.cwfa.org/familyvoice/2001-09/22-26.asp [last accessed 24/08/09].

Kiser, K. (2004) 'The United Nations: An Untold Story,'1 November, 2004, http://www.cwfa.org/articledisplay.asp?id=6623\&department=BLI\&categoryid=re ports [last accessed 26/08/09].

Kleder, M. (2008) 'Russia, Georgia \& Demographic Winter,' Interview with Don Feder, Concerned Women for America, 1 September 2008, http://www.cwfa.org/articles/15721/CWA/misc /index.htm (6:05-7:40) [Last accessed 08/05/09]. 
Kleder, M. (2003) 'Values-Based Investing: A Tool for Pro-Family Activists,' 21 January, 2003.

http://www.cwfa.org/articledisplay.asp?id=3107\&department=CFI\&categoryid=pa pers [last accessed 17/08/09].

Knight, R. (2003) 'Turning Women into Cannon Fodder,' 29 April, 2003, http://www.cwfa.org/articles/3708/CFI/cfreport/index.htm [last accessed 26/08/09].

McGinnis, E. (2005) 'REAL Women's Lobbying Day Succeeds on Capitol Hill,' 29 April 2005, http://www.cwfa.org/articles/8015/CWA/life/index.htm [last accessed 24/08/09].

Macleod, L. A. (1997) 'Sovereignty Under Siege: the United nations plan for your home,' April 1, 1997, http://www.cwfa.org/articles/1832/CWA/nation/index.htm [accessed 24/08/09].

Randall, L. (2006) 'Global Warming Fanatics Warming Up to Evangelicals: What's the real tactic?' 19 December, 2006, http://www.cwfa.org/articledisplay.asp?id= $12033 \&$ department=CWA\&categoryid=misc [last accessed 28/08/09].

Randall, L. (2006) 'ECI: Evangelical Christians Impolitic? The Hewlett Foundation's answer to global warming? Abort babies.' 27 November, 2006, http://www.cwfa.org/articles/11711/CWA/life/index.htm [last accessed 28/08/09]. Porowski, S. (2003) 'Hijacking a Noble Cause: How Modern Feminism has Abandoned its Founders,' 26 September, 2003, http://www.cwfa.org/images/content/early-v-mod-fem.pdf [last accessed 26/08/09]. Stuber, R. (2006). 'Feminists Step Up Attempt to Ratify CEDAW Treaty,' 1 March, 2006, http://www.cwfa.org/articledisplay.asp?id=10233\&department=CWA\&categoryid =nation [last accessed 20/08/09].

Tooley, M. (2006) 'Not Much Thanksgiving for Episcopalians,' 23 November, 2006 ,

http://www.cwfa.org/articledisplay.asp?id=11888\&department=CWA\&catego ryid=misc [last accessed 30/08/09].

Vineyard, A. (2003) ‘AIDS Funding: A Good Idea Gone Miserably Bad? Abstinence takes a back seat to condoms,' 31 March 2003, http://www.cwfa.org/articles/3645/BLI/femfacts/index.htm [last accessed 24/08/09]. 
Weyrich, P. M. (2005) 'The Next Conservatism: The Next Conservative Economics,' September 7, 2005,

http://www.cwfa.org/articles/8904/CWA/misc/index.htm [last accessed 11/08/09]. (2007) 'CWA Joins Press Conference Announcing Largest Gathering of ProFamily Leaders,' 16 March, 2007, http://www.cwfa.org/articles/12592/MEDIA/family/index.htm [last accessed 17/08/09].

(2004) 'A Christian Women's Declaration,' 8 March, 2004.

http://www.cwfa.org/articles/5338/CWA/misc/index.htm [last accessed 26/08/09]. (2002) 'CEDAW Preys On Needy Women: Political Maneuvering [sic] is Sheer Opportunism,' June 13, 2002,

http://www.cwfa.org/articledisplay.asp?id=1578\&department=BLI\&categoryid=m edia [last accessed 23/08/09].

(2002) 'Beijing+5-Pro-Life, Pro-Family Coalition Wins Big at Beijing+5,' 1 January 2002, http://www.cwfa.org/articles/1922/CWA/nation/index.htm [last accessed 26/08/09].

(2001) 'Apathy \& Childlessness,' 4 December 2001, http://www.cwfa.org/articles/807/BLI/dotcommentary/index.htm [last accessed 30/08/09].

(2000) 'CWA Presents Petition Upholding the Home, Marriage and Family to Ambassador Linda Tarr-Whelan,' 6 August 2000, http://www.cwfa.org/articles/1917/CWA/nation/index.htm [last accessed 01/06/09].

(1999) 'UNFPA and PPFA advance the victimization of women in Kosovo,' 16 April, 1999, http://www.cwfa.org/articledisplay.asp?id=1374\&department=CWA\&categoryid=1 ife [last accessed 19/08/09].

(1998) 'The United Nations,' 15 April, 1998, http://www.cwfa.org/articles/1852/CWA/nation/index.htm [last accessed 24/08/09].

(1997) 'United Nations attempts to steal US sovereignty,' 5 March, 1997, http://www.cwfa.org/articles/1830/CWA/nation/index.htm [last accessed 24/08/09]. 
(1996) 'United Nations,' 16 December 1996,

http://www.cwfa.org/articles/1828/CWA/nation/index.htm [last accessed 24/08/09].

(n. d.) 'Stand With Us to Protect the American Family' http://www.cwfa.org/support_cwa.asp [last accessed 11/06/08].

(n. d.) 'Today,' http://www.cwfa.org/history.asp [last accessed 15/06/08].

(n. d.) 'Who's Who in CWA,'

http://www.cwfa.org/articledisplay.asp?id=2112\&department=CWA\&categoryid [last accessed 11/08/09].

(n. d.) 'About CWA,' www.cwfa.org/about.asp [last accessed 11/06/08].

Croft, S. (2007), 'Thy Will be Done: The New Foreign Policy of America's Christian Right,' International Politics, no. 44.

Detwiler, F. (1999) Standing on the Premises of God: the Christian Right's Fight to

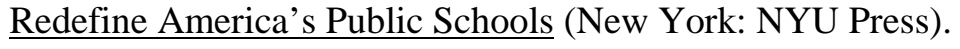

Diamond, S. (1998) Not By Politics Alone: the Enduring Influence of the Christian Right (New York, The Guilford Press).

Diamond, S. (1995) Roads to Dominion: Right wing Movements and Political Power in the United States (New York: The Guilford Press).

Eager, P. W. (2004) 'From Population Control to Reproductive Rights: Understanding Normative Change in Global Population Policy (1965 - 1994),' Global Society, vol. 18 , no. 2.

Epstein, C. (2008) The Power of Words in International Relations: Birth of an AntiWhaling Discourse, (Cambridge: Massachusetts Institute of Technology Press).

Faludi, S. (1991) Backlash: The Undeclared War Against American Women (London: Chatto \& Windus).

Family Research Council publications:

Blackwell, K. (2008) 'Homeschoolers in the crosshairs of the NEA,' Perspective, March 20, 2008, http://www.frc.org/get.cfm?i=PV08L09 [last accessed 12/08/09]. Blackwell, K. (2007) 'Protecting the Human Dignity of the Girl Child Worldwide,' 1 November, 2007, http://www.frc.org/get.cfm?i=PV08L11 [last accessed 20/08/09]. 
Carlson, A. (2004) 'Marriage and Procreation: On Children As The First Purpose of Marriage,' Family Policy Lecture, October 20, 2004, http://www.frc.org/get.cfm?i=PL04J01 [last accessed 30/08/09].

Frohnen, B. (2001) 'Witherspoon lecture: T. S. Eliot on the necessity of Christian Culture,' http://www.frc.org/get.cfm?i=WT01A1 [last accessed 15/08/09].

Fagan, P. F., R. E. Rector and L. R. Noyes (2003) 'Why Congress Should Ignore Radical Feminist Opposition to Marriage,' Family Research Council Backgrounder No. 1662, June 16, 2003, http://www.frc.org/get.cfm?i=LH08H41 [last accessed 01/06/09].

Fagan, P. (2001) 'How UN conventions on women's and children's rights undermine family, religion and sovereignty,' February 5, 2001, http://www.frc.org/get.cfm?i=LH08H21 [last accessed 02/01/09]. Jenkins, P. (2003) 'Witherspoon Lecture: Sibling Rivalry Among the Children of Abraham: Global Conflict and Cooperation Between Islam and Christianity,' July 18, 2003, http://www.frc.org/get.cfm?i=WT04C01 [last accessed 20/08/09]. (2008) 'Family Research Center's Family Policy Lecture: Demographic Winter Policy Discussion,' available at http://www.frc.org/get.cfm?i=PL08E02 [last accessed 28/08/09].

(2004) 'Witherspoon Lecture: Natural Rights and the American Experiment: Some Problems for Christian Theology,' March 12, 2004, http://www.frc.org/get.cfm?i=WT04C02 [last accessed 20/08/09]. (2003) 'Historic Reality and Future Hope: Christopher Dawson's Vision of Christianity and Culture,' November 11, 2003, http://www.frc.org/get.cfm?i=WT03K01 [last accessed 26/08/09]. (2001) 'The Culture War in Perspective: Lessons from the Career of Abraham Kuyper,' Witherspoon Lecture, 15 August 2001, Family Research Council, http://www.frc.org/get.cfm?i=WT01G1, [last accessed 05/04/09].

Feder, D. (2008) 'Demographic Winter: the decline of the human family,' SRB Documentary, LLC. [DVD], (Courtesy Victoria University of Wellington Library). Focus on the Family publications: 
Cameron, N. (2001) 'Preserving the Ethics in Bioethics,' September/October 2001, http://www.citizenlink.org/FOSI/bioethics/A000001352.cfm [last accessed 20/08/09].

Carlson, A. and P. Mero (2004) 'Traditional Families of the world, unite!' Focus on the Family Issue Analysis, http://www.citizenlink.org/FOSI/marriage/A000002224.cfm [last accessed 14/08/09].

Dobson, J. C. (2007) 'Children are a blessing and a treasure,' 17 April, 2007, http://www.citizenlink.org/focusaction/fofafeatures/A000006801.cfm [Accessed 30/08/09].

Dobson, J. C. (2006) 'The Battles Ahead,' 4 January 2006, http://www.citizenlink.org/focusaction/fofafeatures/A000006835.cfm [last accessed 30/08/09].

Dobson, J. C. (2005) 'Good News regarding families around the world,' July 2005, http://www2.focusonthefamily.com/docstudy/newsletters/A000000762.cfm [last accessed 20/08/09].

Dobson, J. C. (2004) 'Radical Feminism Shortchanges Boys: Dr Dobson Considers the feminist movement's affect [sic] on boys and shares an excerpt from Bringing up Boys,' November 2004, http://www2.focusonthefamily.com/docstudy/newsletters/A000000370.cfm [last accessed 01/06/09].

Dobson, J. C. (2004) 'Eleven Arguments Against Same-Sex Marriage,' Focus on the Family Action,

http://www.citizenlink.org/FOSI/homosexuality/maf/A000004753.cfm [last accessed 12/08/09].

Dobson, J. C. ((2002) 'Odd, Outrageous and Over the Top,' January 2002, http://www2.focusonthefamily.com/docstudy/newsletters/A000000362.cfm [last accessed 26/08/09].

Dobson, J. C. (2000) 'The Future of the Family,' January 2000, http://www2.focusonthefamily.com/docstudy/newsletters/A000000794.cfm [last accessed 19/08/09].

Dobson, J. C. (1997) 'Dr Dobson Discusses Families Under Fire,' July 1997, http://www2.focusonthefamily.com/docstudy/newsletters/A000000280.cfm [last accessed 28/08/09]. 
Finger, R. (2005) 'The Earth's Population: What is the Real Problem?' Focus on the Family Issue Analysis,

http://www.citizenlink.org/FOSI/worldview/A000001564.cfm [last accessed 30/08/09].

Mathewes-Green, F. (2000) 'Susan B. Anthony: pro-life feminist,' January 2000, http://www2.focusonthefamily.com/focusmagazine/sohl/A000000164.cfm [last accessed 24/08/09].

Stanton, G. T. (2007) 'Family Formation Trends and Analysis: US Overview 2007: Children: the health of growing up in America' http://www.citizenlink.org/pdfs/fosi/marriage/07 Family Formation Trends Child ren.pdf [last accessed 30/08/09].

Stanton, G. T. (2005) 'Ten Persuasive Answers to the question... Why not gay marriage?'

http://www.citizenlink.org/pdfs/fosi/marriage/Why Not Gay Marriage Bklt.pdf [last accessed 13/06/09].

Tackett, D. (2006) 'Living in Reality' http://www.focusonthefamily.com/faith/christian worldview/why is a christian worldview_important/living_in_reality.aspx [last accessed 26/08/09]. (2008) 'Cause for Concern (Abstinence),' Focus on the Family Issue Analysis, http://www.focusonthefamily.com/socialissues/abstinence/abstinence_before_marri age/cause for concern.aspx [last accessed [14/08/09].

(2008) 'Myanmar receives condoms before food, medicine,' 28 May, 2008, http://www.citizenlink.org/CLBriefs/A000007534.cfm [last accessed 20/08/09]. (2005) Culture Clips, September 18, 2005, http://www.pluggedinonline.com/cultureclips2/a0002330.cfm [last accessed 01/06/09

(n. d.) 'Parental Rights Statement,' http://www.citizenlink.org/FOSI/education/pe/A000001425.cfm [last accessed 19/08/09].

(n. d.) 'Our Mission, Vision, and Guiding Principles, http://www2.focusonthefamily.com/aboutus/A000000408.cfm [08/09/09].

(n. d.) 'About Us,' www.focusonthefamily.com [last accessed 25/01/09]. 
Gardiner, S. (2006) 'Concerned Women for America: A Case Study,' Coalition for Human Dignity, at www.feminism.eserver.org/cw-of-a.txt [last accessed 06/06/08].

Garner, M. (1999) 'Death in the midst of life,' BBC News Online, Tuesday 29 June 1999, at http://news.bbc.co.uk/1/hi/special_report/1999/06/99/world_population/379943.st $\underline{\mathrm{m}}$ [last accessed 15/07/09].

Girard, F. (2002) 'UN Special Session on Children: Bush Administration Continues its Attacks on Sexual and Reproductive Health,' Reproductive Health Matters, vol. 10, no. 20.

Greek, C. E. and W. Thompson, (1992) 'Antipornography Campaigns: Saving the Family in America and England,' International Journal of Politics, Culture and Society, Vol. 5, No. 4.

Grimes, S. (1998) 'From population control to "reproductive rights": Ideological influences on population policy.' Third World Quarterly, vol. 19, no. 3, p. 375.

Herman, D. (2001) 'Globalism's Siren Song: the United Nations and International Law in Christian Right Thought and Prophecy,' the Sociological Review, vol. 49, no.1

Hixson, W. B. (1992) Search for the American Right Wing: An Analysis of the Social Science Record, 1955-1987 (New Jersey: Princeton University Press).

Hopson, R. E. and D. R. Smith (1999) 'Changing Fortunes: An Analysis of Christian Right Ascendance within American Political Discourse,' Journal for the Scientific Study of Religion, Vol. 38, No. 1.

The Howard Center publications:

Balmforth, K. (1999) 'Hijacking Human Rights: Remarks to the WCF II,' November 17, 1999. World Congress of Families, http://www.worldcongress.org/wcf2_spkrs/wcf2_balmforth.htm [last accessed 27/08/09].

Carlson, A. (2006) 'World Congress of Families Cautions Poland Against Legalizing Abortion,' The World Congress of Families Press Release, 10 July 2006, http://profam.org/press/wcf.pr.060710.htm [last accessed 26/08/09]. Carlson, A. (2005) 'Beyond the Culture War: On the Natural Family: A Manifesto,' Concerned Citizens for America town hall meeting, 20 October 2005, Central Christian Church, Rockford, Illinois, http://www.profam.org/docs/acc/thc.acc.cca.051020.htm [last accessed 29/08/09]. 
Carlson, A. (2005) 'Defining Family Friendly,' Remarks for a public dialogue cosponsored by the Sutherland Institute and the Hinkley Institute of Politics, The University of Utah, 23 September 2005, http://www.profam.org/docs/acc/thc.acc.dfu.050923.htm?search [last accessed 29/07/09].

Carlson, A. (2005) 'Europe and the Christian Democracy Movement: A Once and Future Hope?' A lecture to the Witherspoon Fellowship, Washington DC, 20 July 2005, http://www.profam.org/docs/acc/thc_acc_frc.Christian.Democracy.htm [last accessed 25/08/09].

Carlson, A. (2005) 'On the World Congress of Families,' Presentation to the Charismatic Leaders Fellowship Jacksonville, Florida January 12, 2005. The Howard Center, http://www.profam.org/docs/acc/thc.acc.020112.wcf.htm [last accessed 24/08/09].

Carlson, A. (2004) 'Standing for Liberty: Marriage, Virtue and the Political State,' a family policy lecture to the Family Research Council, Washington DC, June 16, 2004, http://www.profam.org/docs/acc/thc_acc_frc_sfl_040616.htm [last accessed 25/08/09].

Carlson, A. (2004) 'Why are we here?' The Family in America, vol. 18, no. 6, June, 2004,

http://www.profam.org/pub/fia/fia_1806.htm?search=why\%20are\%20we\%20here \&opt=EXACT [last accessed 23/08/09].

Carlson, A. (2004) 'Globalizing Family Values,' A talk for the Charismatic Leader's Fellowship, The Howard Center, 12 January, 2004, http://www.profam.org/docs/acc/thc.acc.globalizing.040112.htm [last accessed [08/09/09].

Carlson, A. (2003) ‘The Curious Case of Gender Equality’ The Ingersoll Prize Symposium, Belmont, North Carolina, 17-18 November, 2003, http://www.profam.org/docs/acc/the acc 031017.htm [last accessed 26/08/09]. Carlson, A. (2003) 'World Population Trends and the Retreat from Marriage,' Speech to the Illinois Association of Scholars at Loyola University, Chicago, Illinois, 5 April, 2003, http://www.profam.org/docs/acc/thc_acc_loyola030405.htm [last accessed 30/08/09]. 
Carlson, A. (2002) 'When Feminism Was a Mental Illness: Tales and Lessons from the 1950s,' the Family in America, vol. 16, no. 10, October, 2002, http://www.profam.org/pub/fia/fia 1610.htm [last accessed 26/08/09].

Carlson, A. (2002) 'Love Is Not Enough: Toward the Recovery of a Family Economics,' 28 June, 2002,

http://www.profam.org/docs/acc/thc acc frc love 020628.htm [last accessed 25/08/09].

Carlson, A. (2002) "The Family" at the United Nations: What Went Wrong? And How To Get It Right Again,' remarks to the seminar on the UN Convention on The Rights of the Child, Awakenings Conference, The Cloister, Sea Island, Georgia, January 4-6, http://www.profam.org/docs/acc/thc acc cloister020104.htm [last accessed 19/08/09].

Carlson, A. (2000) “"The family” at the United Nations: what went wrong?' The Howard Center for Family Religion and Society, The Family in America, Vol. 14, No. 8, http://www.profam.org/pub/fia/fia_1408.htm [last accessed 06/09/09]. Carlson, A. (1999) 'Depopulation and the New World Social Order,' Keynote Address to the Australian Regional Conference of the World Congress of Families II, Melbourne, Australia, August 7, 1999, http://www.profam.org/docs/acc/thc_acc_depop.htm [last accessed 26/08/09]. Carlson, A. (1998) 'Twenty-Five Years into the Culture of Death,' Talk for the Rockford Pro-life Breakfast for Clergy and Lay Leaders, 9 January 1998, http://www.profam.org/docs/acc/thc.acc.980109.RvW25th.htm? [last accessed 28/08/09].

Christensen, B. (2006) 'Confronting the Family Implications of the Immigration Debate: Remembering the Laws of Man y las Leyes de la Naturaleza,' The Family in America, vol. 20, no. 9, September 2006, http://www.profam.org/pub/fia/fia.2009.htm?search=demographic\% 20winter\&opt=EXACT [last accessed 03/06/09].

Eberstadt, N. (1999) 'World Population in the $21^{\text {st }}$ Century: Last one out turn off the lights?' Remarks to the World Congress of Families II, Geneva, November 14 17 November 15 1999,

http://www.worldcongress.org/wcf2_spkrs/wcf2_eberstadt.htm [30/08/09].

Mosher, S. W. (2004) 'Unto the least of these my brethren: US population control policy.' Speech given at the World Congress of Families III, Mexico City, 29 - 31 
March 2004, http://www.worldcongress.org/wcf3_spkrs/wcf3_mosher.htm? [last accessed 08/09/09].

Sprigg, P. (2004) 'Homosexuality: The Threat to the family and the attack on Marriage,' World Congress of Families III, Mexico City, http://www.frc.org/get.cfm?i=PD04F01 [last accessed 19/08/09].

Tatad, F. (1999) 'The Family and Population Control,' Remarks to the World Congress of Families II, November 15 1999, Geneva, November 14 - 17, http://www.worldcongress.org/wcf2_spkrs/wcf2_tadad.htm [last accessed 28/08/09].

(2007) 'If you believe in the family, come to Warsaw,' World Congress of Families IV flyer, www.worldcongress.org/WCF4/wcf4.nmx0701.htm [last accessed 13/07/09].

(2007) World Congress of Families Family Update Online! vol. 5, iss. 51, http://www.worldcongress.org/WCFUpdate/Archive05/wcf update 551.htm? [last accessed 08/09/09].

(2006) The Religion and Society Report, vol. 23, no. 1, January/February 2006, http://www.profam.org/pub/rs/rs.2301.htm [last accessed 26/08/09].

(2006) 'World Congress of Families Supports Latvian Decision to Withhold Special Rights from Homosexuals,' World Congress of Families Press Release, 26 June 2006, http://www.profam.org/press/wcf.pr.060626.htm [last accessed 24/08/09].

(2005) The Religion and Society Report vol. 22, no. 7, October/November 2005, http://www.profam.org/pub/rs/rs_2207.htm [last accessed 21/04/08].

(2005) The Religion and Society Report, vol. 22, no. 2, March 2005, http://www.profam.org/pub/rs/rs_2202.htm?search [last accessed 25/08/09 (2005) 'The Natural Family: a Manifesto,' WCF Update, Online! vol. 6, no. 12, 22 March, 2005, http://www.worldcongress.org/WCFUpdate/Archive06/wcf_update_612a.htm [last accessed 27/08/09].

(2004) the Family in America, vol. 18, no. 9, September 2004, http://www.profam.org/pub/fia/fia 1809.htm [both accessed 28/08/09]. 
(2003) The Religion and Society Report, vol. 20, no. 7/8, August 2003, http://www.profam.org/pub/rs/rs_2007.htm?search=globalization\&opt=EXACT [last accessed 12/08/09].

(2003) The Religion and Society Report, vol. 20, no. 4, April 2003, http://www.profam.org/pub/rs/rs_2004.htm?search=globalization\&opt=EXACT [last accessed 16/08/09].

(2002) The Religion and Society Report, vol. 19, no. 9, September 2002. http://www.profam.org/pub/rs/rs_1909.htm?search=cherished\%20values\&opt=EX ACT [accessed 15/08/09].

(2002) The Religion and Society Report, vol. 19, no. 3 March 2002. http://www.profam.org/pub/rs/rs_1903.htm?search=globalization\&opt=EXACT [last accessed 11/08/09].

(2001) The Religion and Society Report, vol. 18, no. 10, October 2001. http://www.profam.org/pub/rs/rs 1810.htm [last accessed 08/09/09]. (2001) The Religion and Society Report, vol. 18, no. 6, June 2001, http://www.profam.org/pub/rs/rs 1806.htm [last accessed 25/08/09]. (2000) The Religion and Society Report, vol. 17, no. 1, January 2000, http://www.profam.org/pub/rs/rs_1701.htm?search=Islamic\%20family\&opt=ALL [last accessed 12/08/09].

(n. d.) 'Frequently asked questions,' http://www.profam.org/THC/xthc faq.htm [last accessed [08/09/09].

Human Life International publications:

Clowes, B., (2004) 'Pro-Life Missionary Trip: Nigeria,' 25 May, 2004, http://www.hli.org/mission_nigeria_2004.html [last accessed 16/11/06]. Clowes, B. (2002) 'Pro-Life Missionary Trip: Hong Kong,' October 2002, http://www.hli.org/mission hong kong 2002.html, [last accessed 17/11/06].

Euteneuer, T. J. (2004) ‘Pro-Life Missionary Trip: Mexico'’ March 29, 2004, http://www.hli.org/mission_mexico_2004.html [last accessed 21/12/06].

Euteneuer, T. J. (2004) 'Pro-Life Missionary Trip: Venezuela,' 30 June, 2004, http://www.hli.org/mission venezuela 2004.html [last accessed 21/12/06].

Euteneuer, T. J. (2003) 'Pro-Life Missionary Trip: India,' Human Life International, 19 November, 2003. Accessed at http://www.hli.org/mission_india_2003.html [last accessed 17/11/06]. 
Euteneuer, T. J. (2003) 'Pro-Life Missionary Trip: Colombia.' 6 October 2003, http://www.hli.org/mission_colombia_2003.html [last accessed 21/12/06].

Euteneuer, T. J. (2003) 'Fighting the Global De-Population Movement,' Human Life International, Humanae Vitae 35th Anniversary Conference, Sydney, Australia, July 25, 2003. http://www.hli.org/commentaries_fr_tom_population_ control fighting global pop.html [last accessed 13/11/07].

Euteneuer, T. J. (2003) 'Pro-Life Missionary Trip: El Salvador' 28 - 30 June 2003, http://www.hli.org/mission_el_salvador_2003.html [accessed 21/12/06].

Euteneuer, T. J. (2003) 'Pro-Life Missionary Trip: Costa Rica,' 30 June 2003, http://www.hli.org/mission coasta rica 2003.html [last accessed 21/12/06].

Euteneuer, T. J. (2003) 'Pro-Life Missionary Trip: Nicaragua,'24 -28 June 2003, http://www.hli.org/mission_nicaragua_2003.html [last accessed 21/12/ 06].

Euteneuer, T. J. (2003) 'Pro-Life Missionary Trip: Mexico,' 20 January, 2003, http://www.hli.org/mission mexico 2003.html [last accessed 21/12/06].

Euteneuer, T. J. (2002) ‘Pro-Life Missionary Trip: Paraguay,' 14 June, 2002, http://www.hli.org/mission_paraguay_2002.html [last accessed 21/12/06].

Euteneuer, T. J. (2002) 'Pro-Life Missionary Trip: Peru,' 10 - 14 June 2002, http://www.hli.org/mission_peru_2002.html [accessed 30/01/07].

Euteneuer, T. J. (2002) 'Pro-Life Missionary Trip: Kenya,' 8 September 2002, http://www.hli.org/mission_kenya_2002.html [last accessed 17/11/06].

Euteneuer, T. J. (2002) 'Pro-Life Missionary Trip: Tanzania,'1 September, 2002, http://www.hli.org/mission_tanzania_2002.html [last accessed 17/11/06].

Euteneuer, T. J. (2002) 'Pro-Life Missionary Trip: Argentina,' 5 June, 2002, http://www.hli.org/mission argentina 2002.html [last accessed 21/12/06].

Euteneuer, T. J. (2001) 'Pro-Life Missionary Trip: Philippines,' 20 October 2001, http://www.hli.org/mission_philippines_2001_II.html [last accessed 17/11/06].

Meaney, J. (2003) 'Pro-Life Missionary Trip: Malaysia,' Human Life International, 13 November 2003, http://www.hli.org/mission malaysia 2003.html [last accessed $17 / 11 / 06]$.

(2008) Special Report, no. 283, July 2008, http://www.hli.org/sr_jul_08.pdf [Last accessed 30/01/07].

(2008) Special Report, no 279, March 2008, www.hli.org, [last accessed [20/08/08]. 
(2008)Human Life International Front Lines, Spring 2008.

http://www.hli.org/front_lines_spring_2008.pdf [last accessed 17/10/06].

(2006) Special Report, no. 264, December 2006, http://www.hli.org/sr dec 06.pdf [accessed 30/01/07].

(2006) Special Report, no. 259, July 2006, http://www.hli.org/sr_july_06.pdf [accessed 13/11/06].

(2005) Human Life International Front Lines, Fall/Winter 2005, http://www.hli.org/front lines fall winter 2005.pdf [last accessed 17/10/06].

(n. d.) 'HLI - Pro-life Missionaries to the world,'

http://hli.org/index.php/about/mission [last accessed 07/09/09].

(n. d.) 'Our Mission,' http://www.hli.org/mission.html [last accessed 23/02/09].

Jenkins, P. (2007) The Next Christendom: The Coming of Global Christianity (New York: Oxford University Press).

Johnson, E. (1998) 'Dr. Dobson's advice to Christian Women: the Story of Strategic Motherhood,' Social Text, no. 57, Winter 1998.

Joyce, K. (2008) 'Missing: The “Right” Babies,' The Nation, March 3, 2008.

Kaplan, E. (2004) With God on their Side: How Christian Fundamentalists Trampled Science, Policy and Democracy in Bush's White House (New York: The New Press).

Keck, M. E. and K. Sikkink (1998) Activists Beyond Borders: Advocacy Networks in International Politics (Ithaca and London: Cornell University Press).

Kintz, L. (1997) Between Jesus and the Market: The Emotions that Matter in Right-Wing America (Durham: Duke University Press).

Kirby, D. (2002) 'Do Abstinence-Only Programs Delay the Initiation of Sex Among Young People and Reduce Teen Pregnancy?' National Campaign to Reduce Teen Pregnancy, Washington DC, http://www.thenationalcampaign.org/resources/pdf/pubs/abstinence_only.pdf [last accessed 15/07/09].

Kissling, F. and J. O'Brien, 'Bad Faith at the UN: Drawing Back the Curtain on the Catholic Family and Human Rights Institute,' (Catholics for a Free Choice, 2001), http://www.catholicsforchoice.org/topics/other/documents/2001badfaithattheun.pdf [last accessed 11/08/09]. 
Koetsawang, S. (1999) 'A pragmatic intervention to promote condom use by female sex workers in Thailand,' Bulletin of the World Health Organisation, vol. 77, no. 11.

Lessa, I. (2006)' Discursive Struggles Within Social Welfare: Restaging Teen Motherhood,' British Journal of Social Work, vol. 2, iss. 36.

Lindsay, M. (2008) 'American Evangelicalism: New Leaders, New Faces, New Issues,' Faith Angle Conference on Religion and Public Life, May 2008. Available at the Pew Forum for Religion and Public Life, http://pewresearch.org/pubs/883/american-evangelicalism [last accessed 30/6/08].

Little, R. and M. Smith (eds.) (2006) Perspectives on World Politics $\left(3^{\text {rd }}\right.$ edn.) (New York: Routledge).

Manning, C. (1999) God Gave us the Right: conservative Catholic, Evangelical Protestant, and Orthodox Jewish women grapple with feminism (New Brunswick, N.J.: Rutgers University Press).

Marsden, L. (2008) For God's Sake: The Christian Right and US Foreign Policy (London and New York: Zed Books).

McMichael, P. (2004) Development and Social Change: A global perspective, $\left(3^{\text {rd }} \mathrm{edn}\right)$. (Thousand Oaks, CA: Pine Forge Press).

Martin, W. (1996) With God on our side: the rise of the religious right in America (New York: Broadway Books).

Martin, W. (1999) 'The Christian Right and American Foreign Policy,' Foreign Policy, no. 114.

Mearsheimer, J. and S. Walt (2007) The Israel Lobby and US Foreign Policy (New York: Farrar, Strauss and Giroux).

Moen, M. C. (2001) 'Status Politics and the Political Agenda of the Christian Right,' Sociological Quarterly, Vol. 29, No. 3.

Petchesky, R. P. (2000) 'Reproductive and Sexual Rights: charting the course of transnational women's NGOs,' Geneva 2000 Occasional Paper no. 8, United Nations Research Institute for Social Development.

Petchesky, R. and K. Judd (eds.) (1998) Negotiating Reproductive Rights: Women's Perspectives across Countries and Cultures (London: Zed books)

Phillips, K. (2006) American Theocracy: The Peril and Politics of Radical Religion, Oil and Borrowed Money in the $21^{\text {st }}$ Century, (London: Penguin Books). 
Radhakrishnan, P. (2004) 'Religion under Globalization,' Economic and Political Weekly, vol. 39 , no. 13 .

Robertson, R. (1992) Globalization: Social Theory and Global Culture (London: Sage).

Rosen, C. (2004) Preaching Eugenics: Religious Leaders and the American Eugenics Movement (New York: Oxford University Press).

Rossini, D. (ed.) (1995) Theodore Roosevelt to FDR: Internationalism and Isolationism in American Foreign Policy, (Edinburgh: Edinburgh University Press).

Santelli, J. et al (2006) 'Abstinence and abstinence-only education: a review of US policies and programs,' The Journal of Adolescent Health, vol. 38, no. 1.

Shah, T. S. (2004) 'The Bible and the Ballot Box: Evangelicals and Democracy in the "Global South," SAIS Review, vol. 24, no. 2.

Singh et al. (2003) 'Adding it up: the Benefits of Investing in Sexual and Reproductive Health Care,' UNFPA and the Alan Guttmacher Institute, http://www.unfpa.org/upload/lib pub file/240 filename addingitup .pdf [last accessed 13/06/09].

Standaert, M. (2006) Skipping Towards Armageddon: the Politics and the Propaganda of the Left Behind Novels and the LaHaye Empire (New York: Soft Skull Press).

Swatos, W. H. and J. K. Wellman (eds.) The Power of Religious Publics: Staking Claims in American Society (Westport: Greenwood Publishing Group).

Swinski, J. S. (2007) Adapting to Norms at the United Nations: Abortion-Rights and AntiAbortion Networks (Dissertation). University of Maryland, available at https://drum.umd.edu/dspace/handle/1903/7634?mode=full. [last accessed $13 / 10 / 08]$.

Tarrow, S. (1994) Power in Movement: Collective Action, Social Movements and Politics (New York: Cambridge University Press).

Tétrault, M. A. and R. A. Denemark (eds.) (2004) Gods, Guns and Globalization: Religious

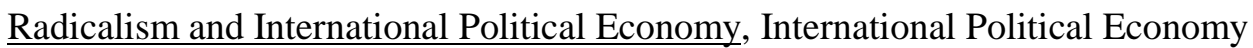
Yearbook, Vol. 13 (London: Lynne Rienner).

Weber, T. (2004) On the Road to Armageddon: How Evangelicals Became Israel's Best Friends, (Michigan: Baker Academic).

Welsome, E. (2006) 'James and the Giant Jihad,' 5280 Magazine, August 2006, http://www.5280.com/issues/2006/0608/feature.php?pageID=502, [last accessed 19/06/08]. 
Wisensale, S. (1991), 'The Family in the Think Tank,' Family Relations, Vol. 40, No. 2. 